UNIVERSIDADE DE SÃO PAULO

ESCOLA DE ENGENHARIA DE SÃO CARLOS

DEPARTAMENTO DE HIDRÁULICA E SANEAMENTO

CENTRO DE RECURSOS HÍDRICOS E ECOLOGIA APLICADA

PROGRAMA DE PÓS-GRADUAÇÃO EM CIÊNCIAS DA ENGENHARIA AMBIENTAL

Juliana Berninger da Costa

\title{
AVALIAÇÃO ECOTOXICOLÓGICA DE EFLUENTE DE TRATAMENTO SECUNDÁRIO DE ESGOTO SANITÁRIO APÓS DESINFECÇÃO COM ÁCIDO PERACÉTICO, CLORO, OZÔNIO E RADIAÇÃO ULTRAVIOLETA.
}

Tese apresentada à Escola de Engenharia de São Carlos, da Universidade de São Paulo, como parte dos requisitos para a obtenção do título de Doutor em Ciências da Engenharia Ambiental

ORIENTADOR: Prof. Dr. Evaldo Luiz Gaeta Espíndola

São Carlos - SP 
AUTORIZO A REPRODUÇÃO E DIVULGAÇÃO TOTAL OU PARCIAL DESTE TRABALHO, POR QUALQUER MEIO CONVENCIONAL OU ELETRÔNICO, PARA FINS DE ESTUDO E PESQUISA, DESDE QUE CITADA A FONTE.

Ficha catalográfica preparada pela Seção de Tratamento da Informação do Serviço de Biblioteca - EESC/USP

\begin{tabular}{|c|c|}
\hline \multirow[t]{3}{*}{ C838a } & $\begin{array}{l}\text { Costa, Juliana Berninger da } \\
\text { Avaliação ecotoxicológica de efluente de tratamento } \\
\text { secundário de esgoto sanitário após desinfecção com ácido } \\
\text { peracético, cloro, ozônio e radiação ultravioleta / } \\
\text { Juliana Berninger da Costa ; orientador Evaldo Luiz Gaeta } \\
\text { Espíndola. -- São Carlos, } 2007 \text {. }\end{array}$ \\
\hline & $\begin{array}{l}\text { Tese (Doutorado) - Programa de Pós-Graduação e Área de } \\
\text { Concentração em Ciências da Engenharia Ambiental -- } \\
\text { Escola de Engenharia de São Carlos da Universidade de São } \\
\text { Paulo. }\end{array}$ \\
\hline & $\begin{array}{l}\text { 1. Esgotos sanitários. 2. Toxidade. 3. Desinfecção. } 4 . \\
\text { Ácido peracético. 5. Cloro. 6. Ozônio. 7. Radiação } \\
\text { ultravioleta. I. Título. }\end{array}$ \\
\hline
\end{tabular}




\section{AGRADECIMENTOS}

Agradeço a todos que contribuíram de alguma forma para a conclusão deste trabalho.

À minha família, que sempre me incentivou e sempre apoiou as minhas escolhas profissionais e pessoais.

Ao meu marido e à minha filha, simplesmente por existirem.

Aos meus amigos que, apesar de muitas vezes não estarem fisicamente próximos a mim, sempre estiveram no meu coração.

Ao meu orientador, que me apoiou em mais uma empreitada.

Ao Prof. Luiz Antônio Daniel, pela co-orientação “extra-oficial”.

Aos membros da banca examinadora, Profa. Odete Rocha, Profa. Ana Teresa Lombardi, Prof. Luiz Daniel e Porf. Roque Passos Piveli, pelas críticas e sugestões.

À Clarisse, pelas conversas, discussões e amizade.

À Jeanette, Patrícia e Luci, pela grande ajuda na fase experimental deste estudo.

À CAPES, pela bolsa concedida.

Aos funcionários do DAAE de Araraquara, que sempre foram bastante prestativos durante as coletas na ETE-Araraquara.

Aos funcionários do CHREA, em especial ao Amândio e ao Marcelo, que foram essenciais para o desenvolvimento deste estudo.

Aos funcionários do Departamento de Hidráulica e Saneamento, em especial ao Paulo e à Luci, pela ajuda nas análises de algumas amostras. 


\section{RESUMO}

COSTA, J. B. (2007). AVALIAÇÃO ECOTOXICOLÓGICA DE EFLUENTE DE TRATAMENTO SECUNDÁRIO DE ESGOTO SANITÁRIO APÓS DESINFECÇÃO COM ÁCIDO PERACÉTICO, CLORO, OZÔNIO E RADIAÇÃO ULTRAVIOLETA. São Carlos, 2007. 178p. Tese (Doutorado) - Escola de Engenharia de São Carlos, Universidade de São Paulo.

Neste estudo foi avaliado o potencial tóxico de diferentes desinfetantes (cloro, ácido peracético, radiação ultravioleta e ozônio) utilizados na desinfecção de esgotos sanitários. Para tanto, foram realizados ensaios de desinfecção (em diversas concentrações e tempos de contato) com o esgoto doméstico originário da Estação de Tratamento de Esgotos da cidade de Araraquara (SP) e, posteriormente, ensaios de toxicidade a fim de verificar possíveis efeitos agudos e crônicos nos seguintes organismos-teste: Daphnia similis, Ceriodaphnia silvestrii, Chironomus xanthus, Danio rerio e Allium cepa. Todos os desinfetantes, nas condições experimentais testadas, foram capazes de produzir efeitos deletérios aos organismos-teste utilizados nesta pesquisa. O cloro foi considerado o desinfetante mais tóxico, sendo seguido pelo ozônio, ácido peracético e radiação UV. Verificou-se ainda que quando o efluente não desinfetado foi tóxico aos organismos-alvo, sua toxidez foi potencializada com a adição dos diferentes agentes desinfetantes. Os resultados obtidos neste estudo sugerem que a utilização do cloro para desinfecção de esgotos sanitários, sem prévia descloração, deve ser revista, em face da eficiência satisfatória de inativação de bactérias proporcionada por outros agentes de desinfecção potencialmente menos tóxicos (tais como o ácido peracético e a radiação UV).

Palavras-chave: Toxicidade, desinfecção, ácido peracético, cloro, ozônio, radiação ultravioleta. 


\begin{abstract}
COSTA, J. B. (2007). ECOTOXICOLOGICAL EVALUATION OF WASTEWATER SECONDARY EFFLUENT DISINFECTED WITH PERACETIC ACID, CHLORINE, OZONE AND ULTRAVIOLET RADIATION. São Carlos, 2007. 178p. Tese (Doutorado) - Escola de Engenharia de São Carlos, Universidade de São Paulo.

In this study, it was evaluated the toxic potential of different disinfectant agents (chlorine, peracetic acid, ultraviolet radiation and ozone) used in the disinfection of urban wastewater. For so much, disinfection assays were accomplished (in several concentrations and contact times) with the domestic sewage from Araraquara city (SP) and toxicity bioassays were developed in order to verify possible acute and chronic effects in the following test-organisms: Daphnia similis, Ceriodaphnia silvestrii, Chironomus xanthus, Danio rerio and Allium cepa. All the disinfectants, in the tested experimental conditions, were capable to produce harmful effects to the test-organisms used in this research. Chlorine was considered the most toxic disinfectant, being followed by ozone, peracetic acid and UV radiation. It was noticed that when the effluent, by itself, was toxic to the test-organism, its toxicity was increased with the different disinfecting agents' addition. The results obtained in this study suggest that the use of chlorine as a wastewater disinfectant, without previous dechlorination, should be reviewed, because it was observed that other disinfection agents (such as peracetic acid and UV radiation) were able to promote satisfactory levels of bacteria inactivation for potentially less toxicity.
\end{abstract}

Keywords: Toxicity, disinfection, peracetic acid, chlorine, ozone, ultraviolet radiation. 


\section{LISTA DE ABREVIATURAS E SIGLAS}

\begin{tabular}{|c|c|}
\hline CE50 & Concentração Efetiva Média \\
\hline CENO & Concentração de Efeito Não Observado \\
\hline $\mathrm{CEO}$ & Concentração de Efeito Observado \\
\hline CL50 & Concentração Letal Média \\
\hline COT & Carbono Orgânico Total \\
\hline DAAE & Departamento Autônomo de Água e Esgotos \\
\hline $\mathrm{DBO}_{5}$ & Demanda Bioquímica de Oxigênio \\
\hline DQO & Demanda Química de Oxigênio \\
\hline ETE & Estação de Tratamento de Esgotos \\
\hline LD & Limite de Detecção \\
\hline LQ & Limite de Quantificação \\
\hline NTK & Nitrogênio Total Kjeldhal \\
\hline OD & Oxigênio Dissolvido \\
\hline PAA & Ácido Peracético \\
\hline $\mathrm{pH}$ & Potencial hidrogeniônico \\
\hline SDF & Sólidos Dissolvidos Fixos \\
\hline SDT & Sólidos Dissolvidos Totais \\
\hline SDV & Sólidos Dissolvidos Voláteis \\
\hline SSF & Sólidos em Suspensão Fixos \\
\hline SST & Sólidos em Suspensão Totais \\
\hline SSV & Sólidos em Suspensão Voláteis \\
\hline $\mathrm{ST}$ & Sólidos Totais \\
\hline STF & Sólidos Totais Fixos \\
\hline STV & Sólidos Totais Voláteis \\
\hline THM & Trihalometano \\
\hline UGRHI & Unidade de Gerenciamento de Recursos Hídricos \\
\hline UV & Ultravioleta \\
\hline
\end{tabular}




\section{SUMÁRIO}

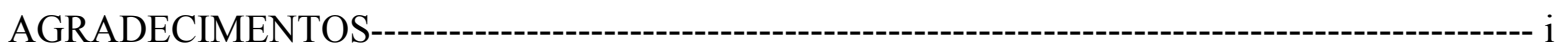

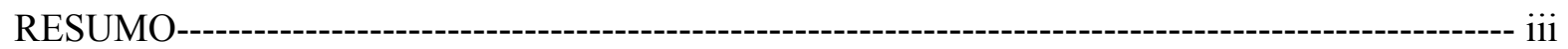



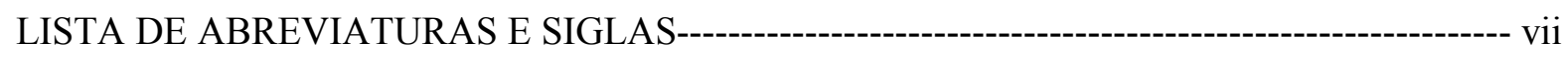

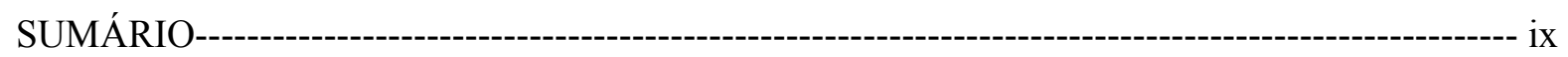

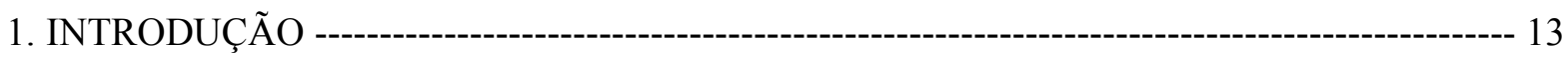



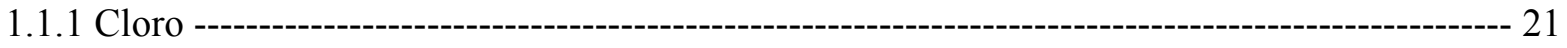

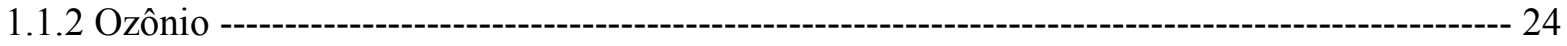

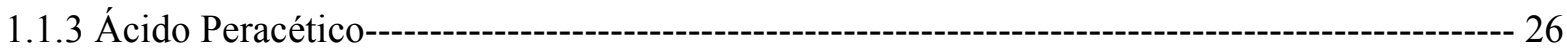

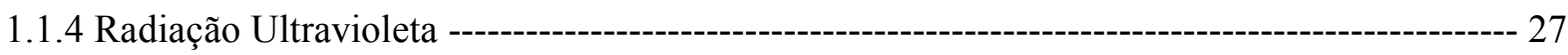

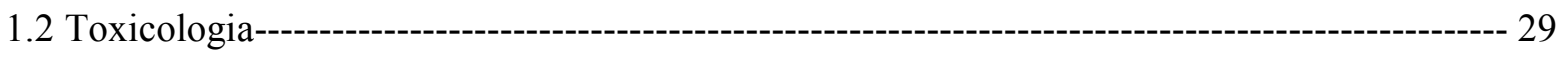

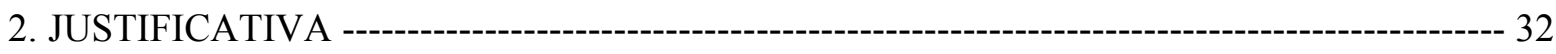

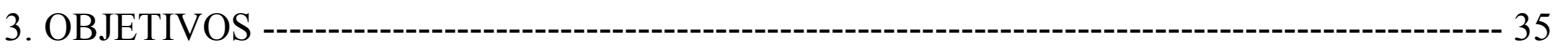



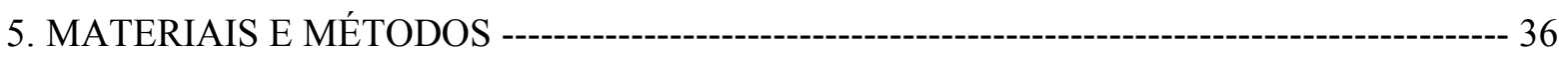

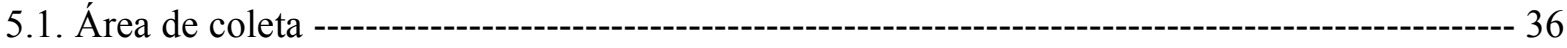

5.2. Coleta, transporte e estocagem das amostras --- 40

5.3. Variáveis hidrológicas da ETE - Araraquara: vazão ---------------------------------------------- 40



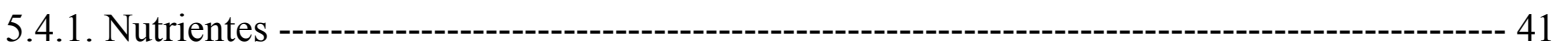

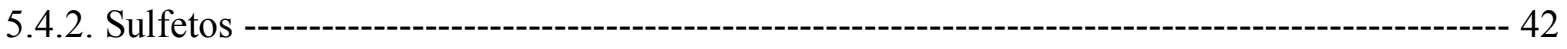

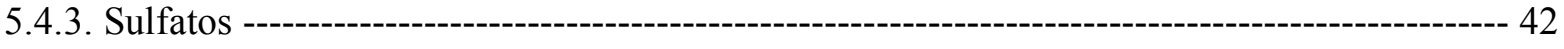

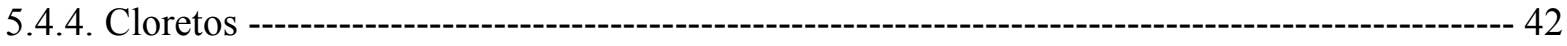

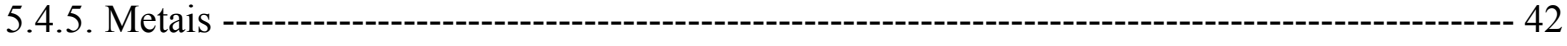

5.4.6 Sólidos totais, sólidos em suspensão totais e sólidos dissolvidos totais ------------------------- 43

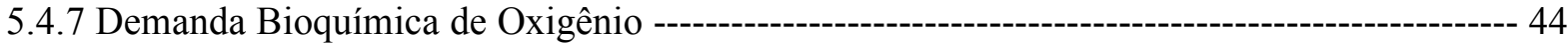

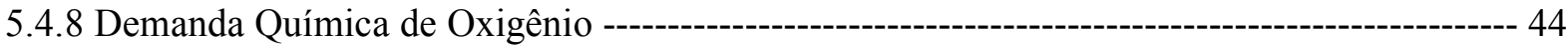

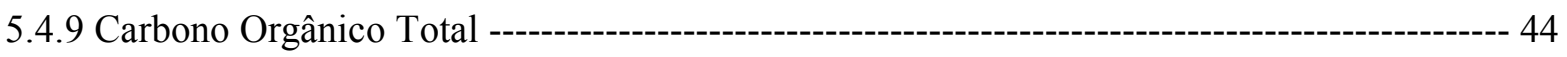

5.4.10 Oxigênio Dissolvido ------------------------------------------------------------------------------------- 44

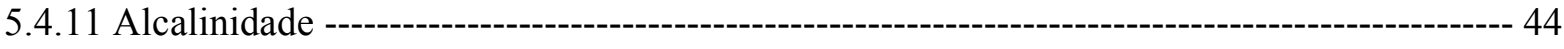

5.4.12 Dureza ------------------------------------------------------------------------------------------------------- 45



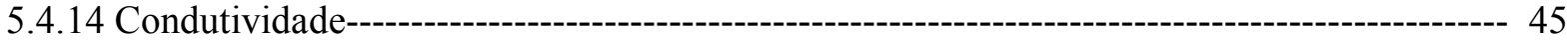




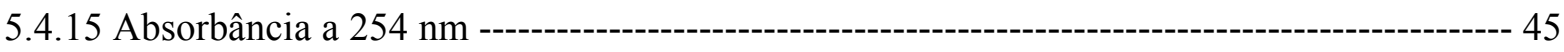

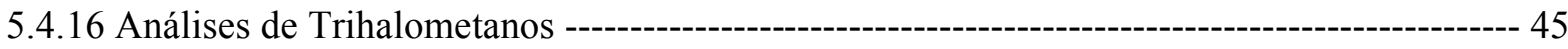

5.4.17 Exames bacteriológicos ------------------------------------------------------------------------------- 46

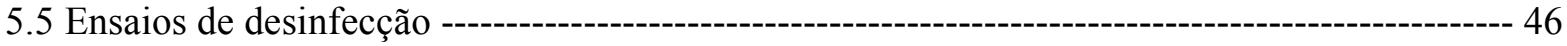

5.5.1 Desinfecção com ácido peracético --- 47

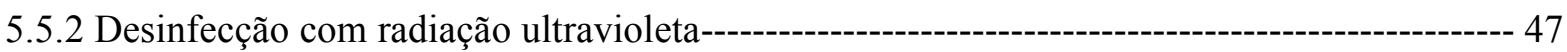

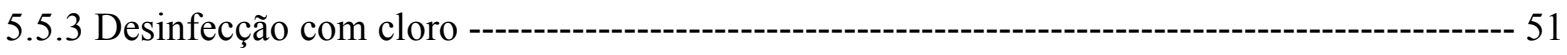



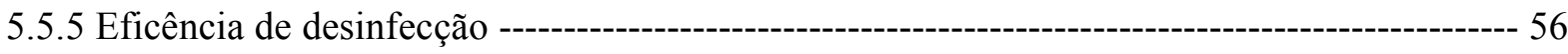

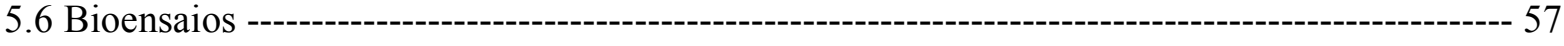

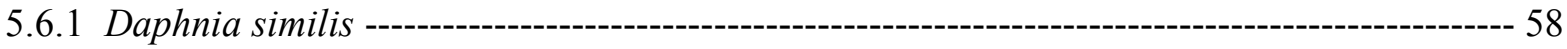

5.6.1.1 Manutenção das culturas de D. similis ------------------------------------------------------------ 59

5.6.1.2 Bioensaios de toxicidade aguda com amostras de esgoto utilizando D. similis como

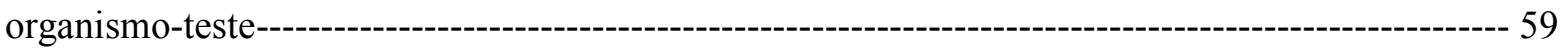

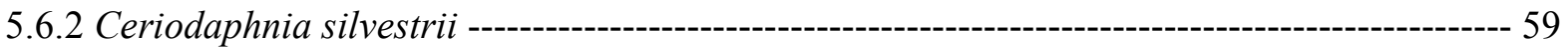

5.6.2.1 Manutenção das culturas de $C$. silvestrii ---------------------------------------------------------- 60

5.6.2.2 Bioensaios de toxicidade crônica com amostras de esgoto utilizando $C$. silvestrii como

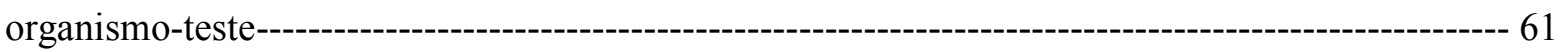

5.6.3 Chironomus xanthus ------------------------------------------------------------------------------ 61

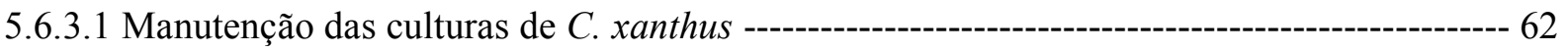

5.6.3.2 Bioensaios de toxicidade crônica com amostras de esgoto utilizando C. xanthus como

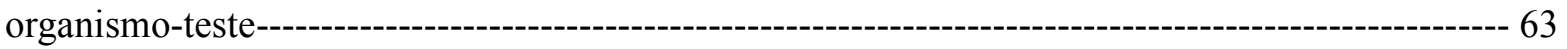

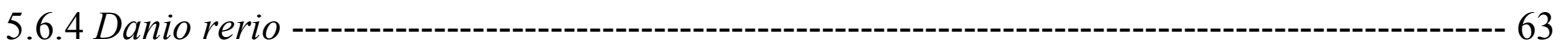

5.6.4.1 Manutenção dos organismos em laboratório----------------------------------------------------- 64

5.6.4.2 Bioensaios de toxicidade aguda com amostras de esgoto utilizando D. reiro como

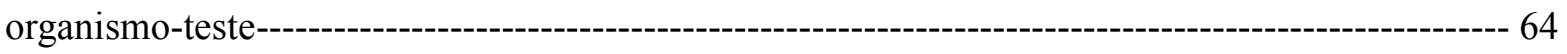

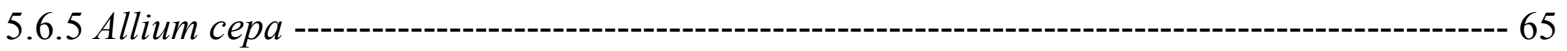

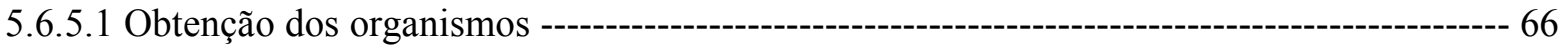

5.6.5.2 Bioensaios de toxicidade aguda com amostras de esgoto utilizando A. cepa como

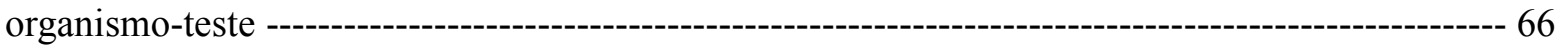

5.6.6 Bioensaios de toxicidade com cloro, ácido peracético e radiação ultravioleta ------------------ 67

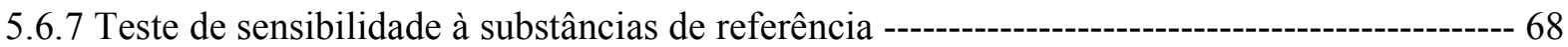

5.6.8 Análises de dados dos bioensaios com amostras de esgoto --------------------------------------- 69

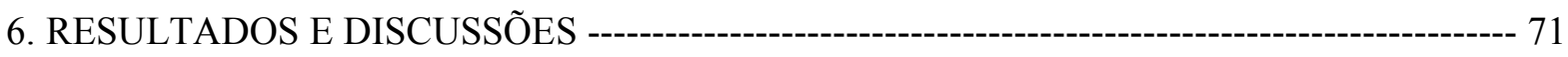


6.1 Caracterização física, química e bacteriológica do esgoto bruto e tratado da ETE - Araraquara: Coleta preliminar 71

6.1.1 Avaliação ecotoxicológica do esgoto bruto e tratado da ETE - Araraquara: Coleta preliminar -

6.2 Variabilidade temporal das características físicas, químicas e bacteriológicas do esgoto tratado

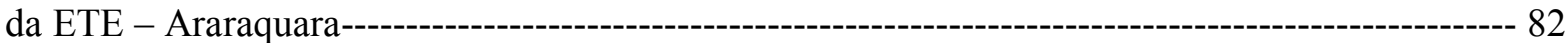

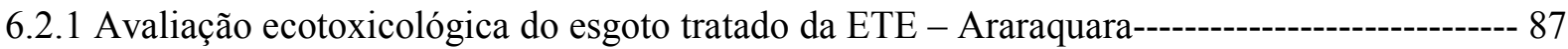

6.3 Ensaios de desinfecção ----- 90

6.3.1 Desinfecção com ácido peracético --- 90

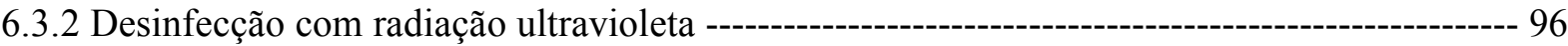

6.3.2.1 Ensaio para a determinação da intensidade média de radiação UV incidente ---------------- 96



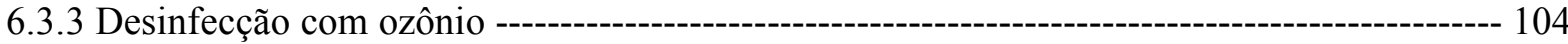

6.3.4 Desinfecção com cloro --- 107

6.3.5 Avaliação Ecotoxicológica do esgoto tratado após os ensaios de desinfecção --------------- 113

6.3.5.1 Avaliação Ecotoxicológica do esgoto tratado após os ensaios de desinfecção $-1^{\mathrm{a}}$ bateria-----

6.3.5.2 Avaliação Ecotoxicológica do esgoto tratado após os ensaios de desinfecção $-2^{\mathrm{a}}$ bateria ---

6.3.5.3 Avaliação Ecotoxicológica do esgoto tratado após os ensaios de desinfecção - $3^{\text {a }}$ bateria -------------------------------------------------------------------------------------------------------------------121

6.4 Bioensaios de toxicidade com cloro, ácido peracético e radiação ultravioleta ------------------- 133

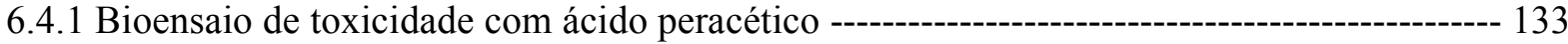

6.4.2 Bioensaio de toxicidade com radiação UV --- 135

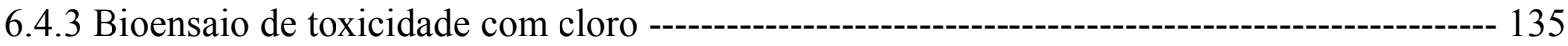

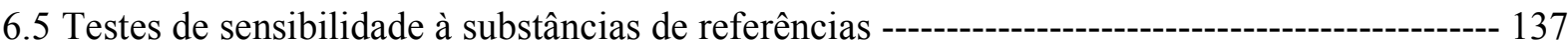

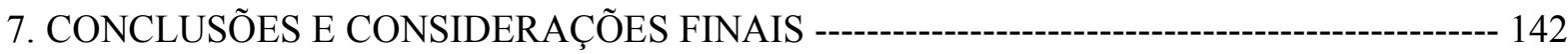

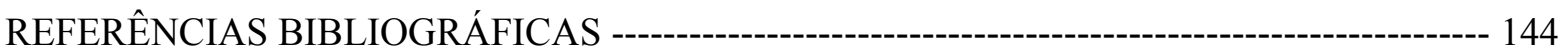

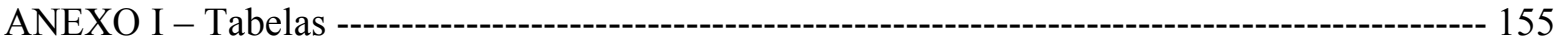

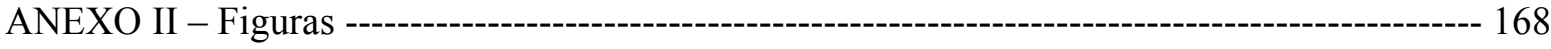




\section{INTRODUÇÃO}

Dentre os ecossistemas aquáticos, os ambientes de água doce, como rios e lagos, constituem apenas $0,007 \%$ da massa total da hidrosfera. Este recurso se destaca por ser indispensável às atividades humanas, pois pode ser utilizado para diversos fins como dessedentação, irrigação, abastecimento público e industrial, pesca, recreação, aqüicultura, via de transporte, disposição de efluentes domésticos e industriais e produção de energia elétrica. Mas, apesar da água doce ser um elemento fundamental para a manutenção da vida na Terra, a sua disponibilidade está cada vez mais limitada em decorrência dos problemas relacionados ao aumento populacional, que acarretam poluição e escassez deste recurso.

Atualmente, existem mais de 1 bilhão de pessoas com baixa disponibilidade de água para consumo doméstico. Considerando que a quantidade de água disponível para o consumo humano permanecerá constante, o cenário futuro é ainda mais dramático, pois a população mundial que, em 1996, era de 5,7 bilhões, será de 8,3 bilhões de habitantes em 2025 (BANCO MUNDIAL, 2000) e de cerca de 10 bilhões de habitantes em 2050 (OMM/UNESCO, 1997 apud LIMA, 2000), acarretando em um significativo aumento de demanda hídrica. Estima-se que no ano de 2030 haverá cerca de 5,5 bilhões de pessoas vivendo em áreas com moderada ou séria falta d'água (WHO, 1998).

A disponibilidade de água para consumo humano também está sendo prejudicada devido aos problemas relacionados aos aspectos qualitativos deste recurso. O desenvolvimento urbano, a expansão industrial e agroindustrial, o desmatamento e uso indevido do solo causam a deterioração progressiva dos corpos d'água e implicam em perda de seus usos múltiplos e perda de biodiversidade, o que provoca alterações, muitas vezes irreversíveis, nos ecossistemas naturais.

Mesmo no Brasil, onde se concentra uma das maiores reservas de água doce do mundo (a disponibilidade hídrica é de $5.745 \mathrm{~km}^{3} /$ ano, segundo o censo do IBGE de 1996), a crescente expansão demográfica e industrial, acompanhada pela falta de gerenciamento e planejamento ambiental e utilização irracional dos recursos hídricos, tem gerado um gradativo e crítico comprometimento das águas continentais superficiais, além de estar causando um sério conflito de ocupação nas bacias hidrográficas.

Os corpos d'água que atravessam grandes áreas metropolitanas, como os rios Tietê e Tamanduateí, na Região Metropolitana de São Paulo, são exemplos típicos de sistemas com problemas ambientais, que têm apresentado, nas últimas décadas, péssimas condições sanitárias, sem sinais de recuperação, demonstrando que sua capacidade de assimilação de cargas poluidoras tem sido muitas vezes ultrapassada (CETESB, 2001). 
Uma das principais fontes antropogênicas de contaminação das águas interiores é o lançamento de efluentes domésticos in natura nos ambientes aquáticos, que afetam a qualidade destes recursos na medida em que promovem alterações de natureza física (alterações na turbidez, coloração, temperatura, condutividade, tensão superficial, viscosidade, etc.), química (variações no pH, DBO, DQO, COT, concentração de nutrientes, etc.), biológica (diminuição da biodiversidade, extinção de espécies, toxicidade, etc.) e também de regime hidrológico, produzindo desequilíbrios, muitas vezes irreparáveis, no ciclo biogeoquímico normal dos sistemas.

Além de problemas ambientais, o lançamento de esgotos de origem orgânica nos corpos d'água receptores favorece a disseminação de várias doenças infecciosas que afetam a saúde humana. Para exemplificar, a cada litro de esgoto bruto lançado em um rio, podem estar presentes cerca de $10^{6}$ a $10^{10}$ organismos coliformes, que direta ou indiretamente estão relacionados a agentes patogênicos (ANDRADE NETO; CAMPOS, 1999). Na tabela 1.1, estão listados os microorganismos mais comumente encontrados em esgotos domésticos e as doenças associadas a eles.

Tabela 1.1. Principais organismos patogênicos presentes no esgoto doméstico não desinfetado.

\begin{tabular}{|l|l|l|}
\hline \multicolumn{2}{|c|}{ Organismo } & \multicolumn{2}{c|}{ Sintomas } \\
\hline Bactéria & Gastroenterite & Diarréia \\
\hline Escherichia coli & Leptospirose & $\begin{array}{l}\text { Febre, dor de cabeça, tonteira, mal estar, } \\
\text { astenia, anorexia }\end{array}$ \\
\hline Leptospira spp. & Febre tifóide e paratifóide & Febre elevada, diarréia \\
\hline $\begin{array}{l}\text { Salmonella typhi } \\
\text { S. parathyphi A e B }\end{array}$ & Cólera & Diarréia e desidratação \\
\hline Vibrio cholerae & Disenteria bacilar & Diarréia, vômito \\
\hline Shigella spp. & & $\begin{array}{l}\text { Diarréia, abscessos no fígado e intestino } \\
\text { delgado }\end{array}$ \\
\hline Protozoário & Disenteria amebiana & Diarréia \\
\hline Entamoeba histolytica & Criptosporidíase & Diarréia, náusea, indigestão, flatulência \\
\hline $\begin{array}{l}\text { Cryptosporidium parvum } \\
\text { C. muris }\end{array}$ & Giardíase & Diarréia, cólica, muco e sangue nas fezes \\
\hline Giardia lamblia & Teníase & Diarréia, constipação intestinal \\
\hline Helminto & Ascaridíase & \\
\hline Taenia solium & & Diarréia, anomalias cardíacas, paralisia, etc. \\
\hline Ascaris lumbricoides & Febre, icterícia, astenia \\
\hline Virus & Gastroenterite, Meningite, etc. \\
\hline Enterovirus (72 tipos) & Diarréia, vômito, anorexia \\
\hline Vírus da Hepatite A e B & Hepatite infecciosa & Gastroenterite \\
\hline Rotavírus &
\end{tabular}

Fonte: USEPA (1999a), Von Sperling (1996).

As doenças relacionadas à água podem ser classificadas em quatro grupos distintos de acordo com sua forma de transmissão (WHO, 1998): 
1) doenças de veiculação hídrica propriamente ditas, que são causadas pela ingestão de água contaminada por fezes e urina humana ou animal (contendo alguns dos agentes patogênicos listados na tabela 1),

2) enfermidades relacionadas à higiene pessoal e limpeza com água (contato de água contaminada com a pele e olhos; ex: escabiose, tracoma, conjuntivite, etc.),

3) doenças associadas à água, isto é, causadas por parasitas de organismos que vivem na água (ex.: esquistossomose, etc.) e

4) moléstias cujos vetores se relacionam com a água, isto é, que são transmitidas por insetos que apresentam parte do seu ciclo de vida na água (ex.: malária, dengue, febre amarela, etc.)

As doenças de veiculação hídrica, propriamente ditas (caso 1), e as transmitidas em função da higiene pessoal insuficiente (caso 2) estão intimamente relacionadas à disposição imprópria dos dejetos e ao consumo de água de péssima qualidade e, ainda hoje, continuam a ser a principal ameaça à saúde humana. Segundo Prüss et al. (2002) e WHO (2002), a diarréia (sintoma predominante em enfermidades de veiculação hídrica, como pode ser visto na tabela 1) é responsável pela morte de mais de 5 milhões de pessoas por ano, o que equivale a 5,3\% de todas as mortes globais anuais.

A incidência das moléstias transmitidas pela água depende de vários fatores como clima e geografia do local, tradição, cultura e hábitos sanitários da população e, principalmente, da quantidade e qualidade da água utilizada no abastecimento público e dos métodos de tratamento e disposição do esgoto sanitário (SETTI et al., 2001).

Por isso, apesar destas doenças ocorrerem em todo o mundo, elas são muito mais freqüentes nas zonas rurais e em países em desenvolvimento (América Latina, África e Ásia), onde há precariedade ou mesmo ausência de saneamento básico e deficiências no abastecimento público de água. Estima-se que cerca de metade da população que vive em países em desenvolvimento está sofrendo, neste momento, de uma ou mais doenças associadas à água, sendo as crianças as principais vítimas (WHO, 2002).

No Brasil, a deficiência de saneamento básico está entre seus cinco maiores problemas de poluição ambiental. Embora as regiões Norte, Nordeste e Centro-Oeste sejam as mais afetadas pela fragilidade do sistema público de saneamento e de abastecimento de água, o índice de tratamento de esgotos também é muito baixo em vários municípios das regiões Sul e Sudeste (BANCO MUNDIAL, 1998).

Segundo a Secretaria dos Recursos Hídricos do Ministério do Meio Ambiente (SRH/MMA, 1998), o abastecimento de água encanada na zona rural atinge apenas $9 \%$ da população, enquanto que nas áreas urbanas esta porcentagem é de cerca de $90 \%$, o que poderia parecer satisfatório caso 
isto não significasse que mais de 11 milhões de pessoas que residem nas cidades não têm acesso à água potável.

Com relação ao saneamento, a precariedade da infra-estrutura sanitária pode ser traduzida pela baixa distribuição de redes coletoras de esgoto (figura 1.1). Dos 9.848 municípios brasileiros, apenas 4.097, os quais são responsáveis por 49\% de todo esgoto orgânico produzido no país, apresentam rede coletora. Deste total, somente 1.383 municípios tratam, de alguma forma, seus dejetos (o que equivale a 32\% do esgoto produzido no Brasil). Portanto, mais de 7.000 municípios lançam suas águas residuárias in natura em rios que, muitas vezes, são utilizados como mananciais (IBGE, 2000).

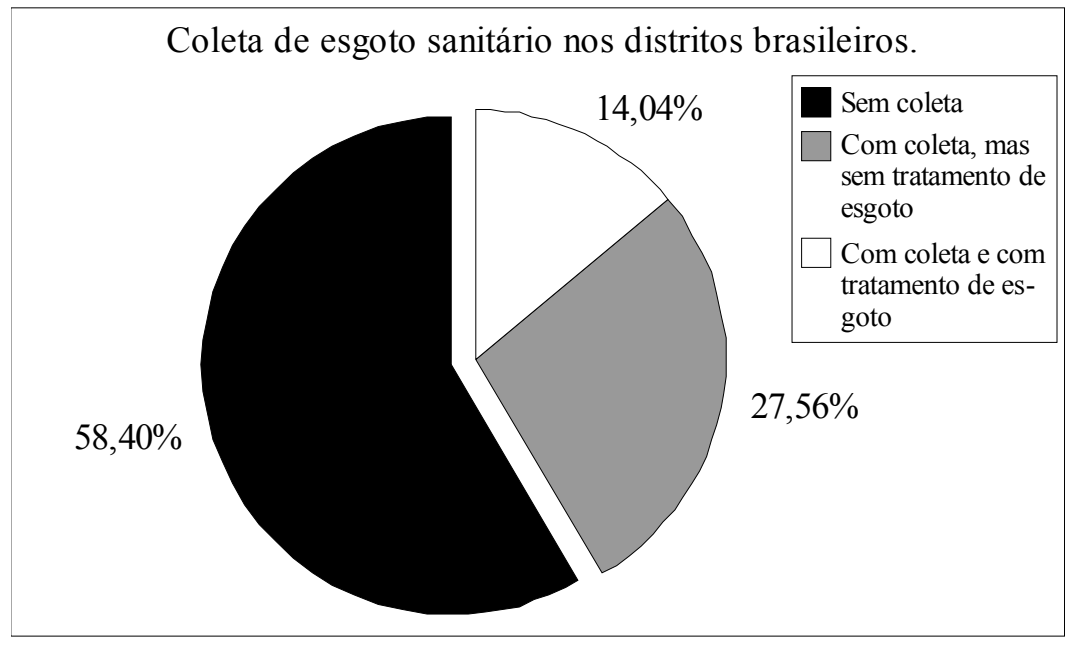

Figura 1.1. Porcentagem dos distritos brasileiros que apresentam cobertura por rede coletora de esgoto sanitário. (Dados: IBGE, 2000).

Como conseqüência da inadequação dos serviços e ações de saneamento no Brasil, estima-se que $65 \%$ das internações hospitalares estejam relacionadas a doenças de veiculação hídrica, sendo a diarréia responsável por cerca de 50 mil mortes de crianças anualmente (SILVA; ALVES, 1999). Nas regiões menos privilegiadas do Brasil, as doenças intestinais infectam 99\% da população infantil e, em alguns estados do Nordeste, o índice de mortalidade infantil (morte de crianças com menos de 1 ano de idade) supera o valor de 60 mortes por mil crianças nascidas vivas, um dos maiores índices das Américas (IBGE, op cit.).

Diante desta situação, surge a necessidade de um controle mais efetivo da disseminação de doenças de veiculação hídrica no Brasil, que deve ser incentivada principalmente pelo governo a partir de mais investimentos na área do saneamento básico, promovendo a implantação de sistemas de tratamento de água e esgoto em diversas localidades do país, garantindo a eficiência de unidades de potabilização já existentes e também a proteção dos mananciais. A recuperação e manutenção da 
qualidade da água dos mananciais não são apenas uma questão de saúde pública, mas também de desenvolvimento sócio-econômico, pois a disponibilidade deste recurso é um dos principais fatores limitantes das oportunidades de desenvolvimento de um país.

A degradação dos mananciais além de gerar sérios problemas ambientais também gera dificuldades operacionais e econômicas para empresas de saneamento, pois os custos operacionais referentes ao tratamento da água e melhoria dos sistemas para a manutenção do atendimento a demanda, aumentam paulatinamente com a redução da qualidade do recurso hídrico, podendo levar até a inviabilização do sistema e a busca de alternativas técnicas do tratamento (LARA et al., 1999).

No sentido de minimizar os impactos ambientais causados por efluentes domésticos, a instalação de estações de tratamento de esgotos sanitários é primordial. A escolha do tipo de tratamento, do número de estações e da eficiência do tratamento de esgotos depende de vários fatores como local, classe, tipo e natureza do esgoto e do corpo hídrico receptor, assim como de áreas disponíveis para implantação do sistema, recursos financeiros e tecnológicos disponíveis e condições da rede coletora existente (ANDRADE NETO; CAMPOS, 1999).

O tratamento de esgotos pode abranger diferentes níveis que são denominados primário, secundário e terciário e que têm como objetivo básico a remoção de sólidos em suspensão e de matéria orgânica. No tratamento primário, ocorre a remoção dos sólidos mais grosseiros e a sedimentação ou flotação de partículas em suspensão. $O$ tratamento secundário envolve a degradação de compostos carbonáceos através da atividade de bactérias aeróbias ou anaeróbias (dependendo do tipo de processo envolvido) e, conseqüentemente, a decomposição de óleos, graxas, carboidratos e proteínas. Já no tratamento terciário, há a redução das concentrações de nitrogênio (através dos processos de nitrificação e desnitrificação) e fósforo (geralmente por tratamento químico). Posteriormente, em muitos casos, ainda se faz necessário um sistema específico para desinfecção, de forma que ocorra a remoção de grande parte dos organismos patogênicos presentes nas águas residuárias (ANDRADE NETO; CAMPOS, op. cit.).

\subsection{Desinfecção}

Em um sistema de tratamento de água ou esgoto, o processo de desinfecção é um dos mais importantes, pois tem como objetivo garantir proteção à saúde pública. É nesta etapa que ocorre a inativação dos microorganismos patogênicos presentes no efluente, minimizando, assim, o risco de proliferação de doenças de veiculação hídrica para os usuários do corpo d'água receptor e para o ambiente. Além de ser um mecanismo primário de destruição de organismos patogênicos, as técnicas de desinfecção podem promover a oxidação da matéria orgânica presente no esgoto, remover ferro e manganês, assim como eliminar gosto e odor (BITTON, 1994). 
Neste sentido, a desinfecção desempenha um papel fundamental no que se refere à garantia da qualidade do efluente gerado, principalmente quando as águas residuárias são destinadas à irrigação, ou quando o corpo hídrico receptor é utilizado para fins de abastecimento público, recreação, pesca, aqüicultura etc. (USEPA, 1999a).

O mecanismo de desinfecção é complexo e depende das propriedades físicas e químicas do agente desinfetante, da natureza do microorganismo patogênico, da interação do desinfetante com o patógeno e da qualidade do efluente a ser desinfetado (ORANGE COAST WATCH, 2002).

Vários tipos de desinfetantes de ação química, física ou fotoquímica podem ser empregados na desinfecção de esgotos sanitários. Os agentes desinfetantes químicos mais utilizados são oxidantes que, por causar danos à parede celular, interferir na biossíntese ou inibir a atividade enzimática dos microorganismos, acabam por destruir ou impossibilitar a reprodução dos patógenos. O desinfetante mais comumente utilizado é o cloro na forma líquida, gasosa ou sólida. $\mathrm{O}$ hipoclorito de sódio $(\mathrm{NaClO})$ e o hipoclorito de cálcio $\left(\mathrm{Ca}(\mathrm{ClO})_{2} \times 2 \mathrm{H}_{2} \mathrm{O}\right)$ são as substâncias mais utilizadas na desinfecção de efluentes sanitários; enquanto que outros compostos como dióxido de cloro $\left(\mathrm{Cl}_{2}\right)$ e cloraminas, ozônio $\left(\mathrm{O}_{3}\right)$, permanganato de potássio $\left(\mathrm{KMnO}_{4}\right)$, peróxido de hidrogênio $\left(\mathrm{H}_{2} \mathrm{O}_{2}\right)$ e ácido peracético $\left(\mathrm{C}_{2} \mathrm{H}_{4} \mathrm{O}_{3}\right)$ são considerados alternativos (DANIEL, 2001).

A retenção dos microorganismos por filtração (membranas sintéticas ou de areia) é um método de desinfecção física utilizado normalmente em combinação com outras técnicas para aumentar sua eficiência. Já a aplicação de calor, que tem ação dissecante nos microorganismos, não é praticada em tratamento de esgotos devido a seu alto custo (ACHER et al., 1997).

A radiação ultravioleta (UV) e a radiação solar são os agentes desinfetantes de ação fotoquímica utilizados com certa freqüência na desinfecção de esgoto sanitário, apesar de ainda serem considerados alternativos. A inativação dos microorganismos pelo uso da radiação UV se dá em nível cromossômico, pois a radiação penetra na célula e é absorvida pelos ácidos nucléicos, interrompendo a sua reprodução e sua capacidade de causar infecção. A radiação também pode afetar as proteínas das células, causando morte aos organismos (USEPA, 1999b).

Dependendo da natureza do esgoto, da qualidade do efluente que se deseja obter, do nível e tipo de sistema de tratamento de esgoto existente pode-se optar por um ou mais tipos de desinfetantes a ser empregado como última barreira de proteção dos recursos hídricos receptores; porém, é importante que o efluente seja tratado adequadamente antes da desinfecção a fim de que o desinfetante seja efetivo. Deve-se também levar em consideração que cada agente desinfetante apresenta vantagens e desvantagens, sendo que alguns parâmetros devem ser previamente avaliados antes da sua utilização como, por exemplo: efetividade na remoção dos agentes patogênicos, custo, facilidade de obtenção do produto, estabilidade do agente desinfetante, segurança durante a manipulação do produto, confiabilidade, grau de periculosidade ao meio ambiente, etc. 
Segundo Campos (1993), a desinfecção dos esgotos sanitários após o tratamento deve ser estudada caso a caso e implantada em todos os locais onde haja risco à saúde humana, principalmente tendo em vista que se trata de uma tecnologia barata face aos benefícios gerados.

Chernicharo et al. (2001) apud Gonçalves et al. (2003), elaboraram um fluxograma de tomada de decisão sobre a desinfecção de esgoto sanitário de uma determinada localidade. O fluxograma, apresentado na figura 1.2, prevê identificação do nível de risco à saúde humana, levando em consideração os aspectos ambientais na aplicabilidade da alternativa de controle.

Sendo assim, se de um lado a desinfecção pode ser extremamente benéfica em termos de inativação de microorganismos patogênicos, promovendo a melhoria na qualidade de vida da população, por outro lado, pode ser danosa ao meio ambiente por também provocar alterações químicas na água submetida a este processo.

Todos os desinfetantes têm a capacidade de induzir alterações químicas nos sistemas, porém, os resultados destas alterações podem não estar restritos apenas à população microbiana. As alterações na composição do efluente podem persistir mesmo após o término do processo de desinfecção, apesar da natureza e extensão destas alterações variarem de acordo com o desinfetante (tipo, concentração e tempo de contato), com o efluente e com os fatores ambientais (pH, alcalinidade, temperatura, condutividade etc.). Tais mudanças químicas podem causar toxicidade do efluente desinfetado (BLATCHLEY III, et al., 1997).

Muitos estudos têm mostrado que diferentes desinfetantes podem reagir com substâncias orgânicas naturais (ácidos húmicos e fúlvicos) presentes nas águas superficiais e nos efluentes domésticos, originando numerosos subprodutos com atividade mutagênica e/ou carcinogênica (MONARCA et al., 2000). Porém, os efeitos tóxicos decorrentes de desinfecção podem ser causados não apenas pelos subprodutos de desinfetantes como também pelos residuais dos próprios agentes de desinfecção.

O residual de um desinfetante é a fração do composto dosado que, depois de satisfeita a demanda, fica disponível para a desinfecção. A toxicidade do residual está relacionada com o grau de reatividade química do composto; portanto, de uma forma geral, quanto mais reativo é o residual, mais tóxico ele é. Quando um desinfetante apresenta um residual persistente, como é o caso do cloro, o mesmo permanece no efluente (juntamente com os subprodutos da desinfecção) mesmo após seu lançamento no corpo hídrico receptor, podendo causar efeito tóxico aos organismos que lá habitam. 


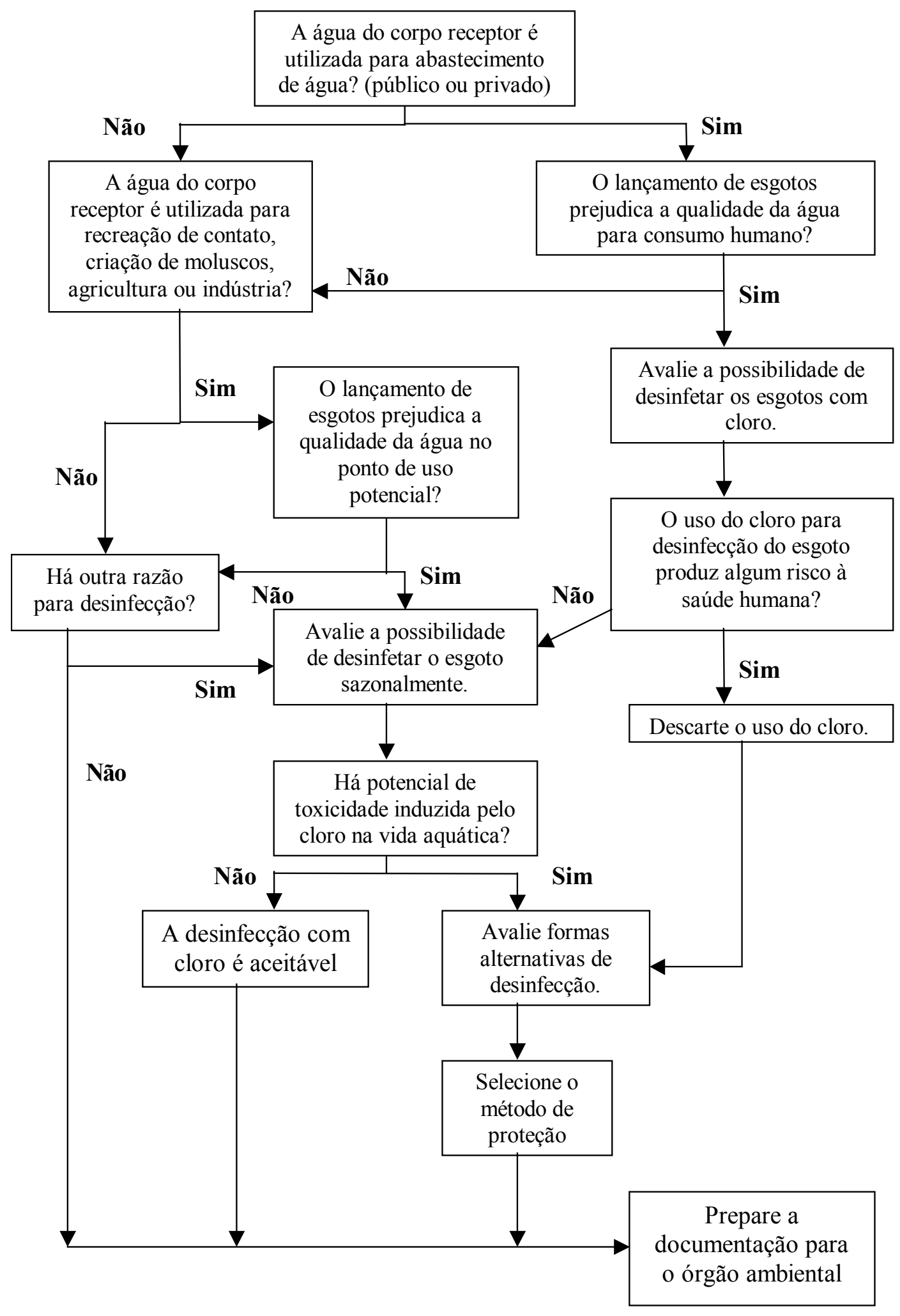

Figura 1.2. Fluxograma para a avaliação local da necessidade e dos requisitos da desinfecção dos esgotos. Fonte: Chernicharo et al. (2001) apud Gonçalves et al. (2003). 
Existem vários exemplos na literatura que demonstram a ocorrência de efeitos deletérios ao ambiente receptor causados por efluentes domésticos submetidos a processos de desinfecção convencionais, sendo que aumentos estatisticamente significativos na toxicidade dos efluentes têm sido atribuídos a técnicas de desinfecção que utilizam, em ordem decrescente: cloração, ozonização e radiação ultravioleta (BLATCHLEY III et al., 1997; MONARCA et al, 2000; THOMPSON \& BLATCHLEY III, 1999).

\subsubsection{Cloro}

O cloro foi descoberto em 1808, porém, suas propriedades bactericidas foram comprovadas apenas em 1881 pelo bacteriologista Koch. O uso do cloro como desinfetante foi aprovado pela American Public Health Association (APHA) em 1886 e a partir do século XIX, este agente químico já era amplamente utilizado na desinfecção de águas de abastecimento público na Europa e EUA (MACÊDO, 1997).

A partir de então, o cloro, principalmente na forma de hipoclorito de sódio, tem sido o desinfetante mais utilizado também na desinfecção de esgotos sanitários devido ao seu baixo custo, efetividade, praticidade e melhoria nas características do efluente (redução da cor, turbidez e odor), porém, este método de desinfecção também tem sido o que causa maiores efeitos adversos à biota que habita o curso hídrico receptor.

A reação entre o hipoclorito de sódio e a água produz ácido hipocloroso e sódio (1.1).

$$
\begin{aligned}
& \mathrm{NaOCl}+\mathrm{H}_{2} \mathrm{O} \leftrightarrow \mathrm{Na}^{+}+\mathrm{ClO}^{-}+\mathrm{H}_{2} \mathrm{O} \\
& \mathrm{Na}^{+}+\mathrm{ClO}^{-}+\mathrm{H}^{+}+\mathrm{OH}^{-} \leftrightarrow \mathrm{HOCl}+\mathrm{NaOH}
\end{aligned}
$$

O ácido hipocloroso ( $\mathrm{HOCl})$, por sua vez, se dissocia em hidrogênio e íons hipoclorito (1.2), sendo que este processo é pH-dependente. O ácido hipocloroso e o íon hipoclorito são denominados de cloro residual livre (CRL).

$$
\mathrm{HOCl} \leftrightarrow \mathrm{H}^{+}+\mathrm{OCl}^{-}
$$

Em pH acima de 8,5 todo o ácido hipocloroso se dissocia ao íon hipoclorito; em contraposição, em pH abaixo de 6,5 não há dissociação deste ácido. Considerando que o efeito germicida do $\mathrm{HOCl}$ é superior ao do $\mathrm{OCl}^{-}$, a desinfecção com o cloro é mais eficiente em meio mais ácido (DANIEL, 2001).

Se amônia ou compostos amoniacais estão presentes no efluente quando se adiciona um derivado clorado, o que é bem provável uma vez que o esgoto apresenta altas concentrações de 
uréia, então há a formação de cloraminas inorgânicas (monocloramina, dicloramina e tricloramina), denominadas de cloro residual combinado (CRC). Estes compostos são resultantes da reação da amônia com o ácido hipocloroso.

As cloraminas (monocloramina, dicloramina) apresentam ação bactericida pelo menos 25 vezes inferior ao ácido hipocloroso. Percebe-se, portanto, que o cloro residual livre é mais reativo do que o cloro residual combinado, o que equivale a dizer que seu potencial tóxico é muito maior.

A presença do cloro residual livre em águas de abastecimento é necessária para que não ocorra uma nova contaminação por microorganismos patogênicos, porém sua persistência em águas residuárias é extremamente maléfica para o corpo hídrico receptor.

O cloro residual (livre e combinado) é o agente ativo da desinfecção que reage quimicamente com substratos orgânicos e inorgânicos. Quando o substrato orgânico é parte de um organismo vivo (fitoplâncton, zooplâncton, nécton, etc.), a reação pode gerar um efeito tóxico no mesmo. A toxicidade pode afetar o metabolismo ou a reprodução do organismo, pode causar alterações cromossômicas e até causar mortalidade.

Sabe-se que quanto maior a concentração de cloro residual (livre ou combinado) que permanece no efluente, maiores são os efeitos adversos ao meio biótico e maior é a área que pode ser impactada. Durante um ensaio de fluxo contínuo, Fisher et al. (1999) verificou que o cloro residual livre causou toxicidade aguda em concentrações de CL50 (concentração que causa letalidade a $50 \%$ dos organismos expostos) de $59 \mu \mathrm{g} / \mathrm{L}$ para a truta arco-íris Oncorhynchus mykiss, $78 \mu \mathrm{g} / \mathrm{L}$ para o Amphipoda Hyalella azteca, $32 \mu \mathrm{g} / \mathrm{L}$ para o Cladocera Daphnia magna e $62 \mu \mathrm{g} / \mathrm{L}$ para o Mysidaceo Mysidopsis bahia (este último organismo é marinho).

Além do próprio cloro residual já se mostrar extremamente tóxico aos organismos vivos, ainda existem os subprodutos da cloração que, desde a década de 1970, são relacionados à indução de disfunções genéticas em organismos a eles expostos.

É notório que ocorre a formação de compostos organoclorados (trihalometanos - THM) a partir da reação do cloro residual livre com determinados precursores presentes no efluente. Tais precursores são substâncias orgânicas, ácidos húmicos, fúlvicos e himatomelânicos, compostos de metahidroxifenol (resorcinol) e $\beta$-dicetonas presentes no material húmico, estruturas de pirrol que ocorrem na clorofila, substâncias resultantes da degradação de vegetais, e compostos aromáticos que podem estar presentes naturalmente na água (MACÊDO,1997).

Os trihalometanos (THM) apresentam em sua estrutura molecular um átomo de carbono, um de hidrogênio e três de halogênios. Dentre os THM, quatro ocorrem em maiores concentrações: clorofórmio $\left(\mathrm{CHCl}_{3}\right)$, diclorobromometano $\left(\mathrm{CHBrCl}_{2}\right)$, dibromoclorometano $\left(\mathrm{CHBr}_{2} \mathrm{Cl}\right)$ e bromofórmio $\left(\mathrm{CHBr}_{3}\right)$. O clorofórmio é o mais abundante, enquanto que os outros três são formados quando há a presença de íons brometo no efluente clorado (SANCHES et al., 2003). 
Os THM são bastante persistentes e se acumulam no sedimento e em ambientes aquáticos. Além de serem considerados carcinogênicos, são indicadores da possível presença de outros compostos organoclorados subprodutos da cloração (ácidos acéticos clorados, haloacetonitrilos, cloropicrin, clorofenóis, cloropropanonas), mais perigosos do que os próprios THM. Em função dos riscos, a EPA estabeleceu em dezembro de 1993 que 30 substâncias químicas são consideradas nocivas à saúde, dentre essas se destacaram os THM (MACÊDO, 1997).

As propriedades toxicológicas dos ácidos haloacéticos ainda não são bem compreendidas, porém, há suspeitas de que estes compostos orgânicos sejam carcinogênicos e causem danos ao fígado, assim como provoquem alterações em nível reprodutivo (COWMAN; SINGER, 1996). Hashimoto et al (1998), por sua vez, verificaram que a alga verde Scenedesmus subspicatus quando exposta ao ácido monocloroacético apresentava $\mathrm{CE}_{10}-48 \mathrm{~h}$ de $7 \mu \mathrm{g} / \mathrm{L}$ (concentração efetiva da substância que causa efeito deletério a 10\% da população em um período de exposição de 48 horas), o que é altamente tóxico.

Plewa et al. (2002) avaliaram a genotoxicidade e citotoxicidade de diversos subprodutos da cloração em células do ovário de hamster chinês AS52. Os pesquisadores observaram que os compostos que estimularam o desenvolvimento de citotoxicidade crônica nas células foram em ordem decrescente: ácido bromoacético (BA) $\gg$ 3-cloro-4-(diclorometil)-5-hidroxi-2[5H]-furano $(\mathrm{MX})>$ ácido dibromoacético $(\mathrm{DBA})>$ ácido cloroacético $(\mathrm{CA})>\mathrm{KBrO}_{3}>$ ácido tribromoacético (TBA). Quanto a genotoxicidade destes agentes, avaliada pelo teste do cometa, verificou-se o seguinte (em ordem decrescente): $\mathrm{BA}>\mathrm{MX}>\mathrm{CA}>\mathrm{DBA}>\mathrm{TBA}>\mathrm{KBrO}_{3}$. $\mathrm{O}$ ácido bromoacético foi 31 vezes mais citotóxico e 14 vezes mais genotóxico do que o MX, sendo que os compostos bromados foram mais tóxicos do que seus análogos clorados.

Como a formação dos subprodutos da cloração é maior em águas com muita carga orgânica e com altas concentrações de amônia, o que caracteriza um esgoto sanitário bruto (REBHUN et al. 1997), o uso do cloro para a desinfecção de efluentes domésticos é objeto de ressalvas. A USEPA sugere que a cloração dos efluentes domésticos só deva ser considerada quando há riscos de saúde pública e não deve ser realizada quando o enfoque primordial é a proteção à vida aquática. Além disso, recomenda que técnicas alternativas de desinfecção sejam consideradas em ocasiões onde as questões de saúde pública e de preservação ambiental entrem em conflito (SPELLMAN, 1999).

Neste sentido, o desenvolvimento de técnicas alternativas de desinfecção tem sido estimulado para a aplicação em efluentes domésticos, dentre eles pode-se citar a ozonização, o ácido peracético e a radiação ultravioleta. Um aspecto importante que deve ser investigado durante o uso destas outras estratégias de desinfecção é o potencial tóxico que estes agentes desinfetantes podem proporcionar ao efluente, principalmente comparando-os aos efeitos causados pelos processos convencionais de desinfecção, como a cloração. 


\subsubsection{Ozônio}

Os primeiros indícios de conhecimento do ozônio datam de 1781, quando seu odor pungente característico foi detectado pela primeira vez, mas somente em 1867 sua fórmula química $\left(\mathrm{O}_{3}\right)$ foi reconhecida. Em 1886, foi descoberta a propriedade mais marcante do ozônio: seu potencial de desinfecção, e em 1893 foi utilizado pela primeira vez no tratamento de água para abastecimento, na Holanda (SANCHES, 2003).

A utilização do ozônio como desinfetante em estações de tratamento de esgotos começou em 1975, porém devido aos altos custos de operação e manutenção dos equipamentos, este sistema de desinfecção acabou sendo abandonado. Atualmente, devido aos avanços tecnológicos, a ozonização já é mais economicamente viável, sendo cogitado como desinfetante alternativo à cloração, uma vez que seu potencial de oxidação é cerca de 1,5 vezes mais forte que do cloro, como pode ser visto na tabela 1.2. De acordo com Spellman (1999), quanto maior é o potencial de oxidação de um desinfetante oxidante, mais rápida é a transferência de elétrons aos microorganismos e, portanto, maior o poder de inativação de bactérias e vírus. Porém, na prática, deve-se levar em consideração que o potencial de desinfecção de um oxidante não é função apenas de seu potencial de oxidação.

Tabela 1.2. Potencial de oxidação de diversos oxidantes (WITT; REIFF, 1995 apud DIAS, 2001).

\begin{tabular}{|c|c|}
\hline Oxidante & Potencial de oxidação (Elétron-volts) \\
\hline Flúor & 2,87 \\
Radical hidroxila & 2,80 \\
Ozônio & 2,70 \\
Ácido peracético & 1,81 \\
Permanganato & 1,68 \\
Dióxido de cloro & 1,57 \\
Hipoclorito de sódio & 1,36 \\
\hline
\end{tabular}

Além de ser utilizado como desinfetante, o ozônio também pode promover a oxidação de compostos como fenol, cianeto, metais pesados, nitritos, sólidos em suspensão e matéria orgânica, removendo a turbidez e a cor do efluente e melhorando, assim, sua qualidade. Porém, a presença destas substâncias no esgoto pode interferir sensivelmente na eficiência de inativação dos microorganismos.

O ozônio é produzido quando moléculas de oxigênio são dissociadas por alguma fonte de energia em átomos de oxigênio e subseqüentemente colidem com uma molécula de oxigênio formando o ozônio (1.3). O ozônio geralmente é produzido por energia elétrica, através da aplicação de corrente alternada de alta voltagem em uma câmara de descarga, na presença de ar 
fresco ou oxigênio puro (USEPA, 1999c). Quando o gás de alimentação é o próprio ar atmosférico pressurizado, a produção de ozônio permanece em torno de $2 \%$ em peso.

$$
\begin{aligned}
& \mathrm{E}+\mathrm{O}_{2} \rightarrow \mathrm{O}^{\bullet}+\mathrm{O}^{\bullet}+\mathrm{E} \\
& \mathrm{O}^{\bullet}+\mathrm{O}_{2} \rightarrow \mathrm{O}_{3}
\end{aligned}
$$

Este gás é muito instável e se decompõe rapidamente a oxigênio após sua geração, quando em contato com a água (1.4).

$$
2 \mathrm{O}_{3} \rightarrow 3 \mathrm{O}_{2}
$$

Quando o ozônio se decompõe na água, são formados os radicais livres $\mathrm{HO}_{2}$ e hidroxilas $\left(\mathrm{OH}^{-}\right)$que apresentam grande capacidade de oxidação (na faixa de $10^{10}$ a $10^{13} \mathrm{Ms}^{-1}$ ) e têm grande influência no processo de desinfecção. Portanto, o mecanismo de desinfecção pode se dar tanto por oxidação direta, através do $\mathrm{O}_{3}$, ou pela ação dos radicais livres sobre o substrato (DANIEL, 2001; TASK FORCE ON WASTEWATER DISINFECTION, 1996).

O ozônio não promove a formação de residual ativo persistente, pois é bastante volátil, decaindo espontaneamente a oxigênio em curto período de tempo. Em água destilada, o ozônio apresenta meia vida de 165 minutos, a $20^{\circ} \mathrm{C}$. Na presença de materiais oxidantes na solução (como é o caso de esgoto doméstico), sua meia vida é bastante reduzida. Logo, a probabilidade do ozônio residual causar toxicidade à biota é mínima. Outra vantagem do ozônio é o fato desta substância aumentar a concentração de oxigênio dissolvido no efluente, o que é benéfico aos organismos aeróbios do corpo hídrico receptor (SAMPAIO, 1985).

Apesar destas vantagens, a ozonização também tem potencial de formar subprodutos. Em geral, a reação do ozônio com matéria orgânica leva a destruição da molécula original formando produtos mais polares, mais facilmente biodegradáveis e com peso molecular menor, como é o caso dos ácidos carboxílicos, que não são tóxicos, e dos aldeídos (de cadeias curtas: butanal, pentanal e heptanal, ou de menor peso molecular: formaldeído, acetaldeído, dialdeído glioxal e ceto-aldeído metil glioxal), cujo potencial tóxico ainda não é bem conhecido. Porém, em alguns casos, na presença de determinadas substâncias, podem ser gerados compostos bastante tóxicos não só ao homem quanto ao meio ambiente (WEINBERG; GLAZE, 1996).

A ozonização de águas que contenham íons brometo, mediante a oxidação de $\mathrm{Br}^{-}$a $\mathrm{HOBr}$ que reage com os precursores dos subprodutos, pode levar a formação de bromofórmios, bromometanos, ácidos acéticos brominados e acetonitrilos brominados. Além disso, a oxidação do brometo pode gerar bromatos. 
O bromato é um subproduto associado tanto a ozonização quanto a cloração. O limite de contaminação máxima de bromatos na água de abastecimento nos EUA é de $10 \mu \mathrm{g} / \mathrm{L}$, pois, como visto anteriormente, os compostos bromados têm alto potencial citotóxico e genotóxico. Acredita-se que a formação de bromatos durante a ozonização seja influenciada pela eficiência de transferência de ozônio para o efluente, pelo tempo de contato, ou, mais provavelmente, pelo ozônio residual, pois a quantidade deste subproduto aumenta com a dose de ozônio aplicada no efluente. Outro subproduto da ozonização que tem potencial tóxico é o peróxido de hidrogênio, cujo limite de

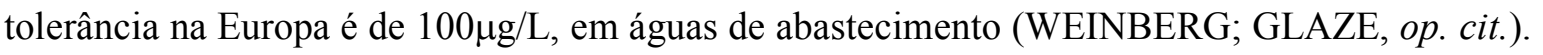

Desta forma, antes de eleger o ozônio como desinfetante substituto à cloração, é importante que se investigue com cautela o efeito tóxico dos seus subprodutos sobre os organismos aquáticos, pois estudos já demonstraram que ambos os métodos de desinfecção tiveram o mesmo efeito de indução mutagênica em testes in vitro (COGNET et al., 1986).

\subsection{3. Ácido Peracético}

O ácido peracético foi patenteado em 1950 por Greenspan e Margulies para ser utilizado como agente germicida no tratamento de frutas e vegetais contra a ação de bactérias e fungos. Desde então, vem sendo utilizado como desinfetante em hospitais e laboratórios, indústrias alimentícias, etc. A utilização do ácido peracético como desinfetante alternativo de esgotos sanitários tem sido bastante difundida atualmente devido ao fato de ser um agente oxidante muito forte (tabela 2), não formar subprodutos potencialmente tóxicos à biota e por se degradar rapidamente em substâncias inócuas e biodegradáveis como ácido acético e oxigênio ativo (SÁNCHEZ-RUIZ et al., 1995 apud SOUZA, 2000).

O ácido peracético é produzido a partir da reação entre o peróxido de hidrogênio e o ácido acético (1.5). Esta reação pode formar até $15 \%$ de ácido peracético e $25 \%$ de água, sobrando um residual de peróxido de hidrogênio de $25 \%$ e de ácido acético de até $35 \%$.

$$
\mathrm{H}_{2} \mathrm{O}_{2}+\mathrm{CH}_{3} \mathrm{OOH} \leftrightarrow \mathrm{CH}_{3} \mathrm{COOOH}+\mathrm{H}_{2} \mathrm{O}
$$

O modo de ação primária do ácido peracético é a oxidação. Portanto, o mecanismo de inativação dos microorganismos se dá através da oxidação da membrana celular externa das bactérias, endosporos, esporos, etc. Dentro da célula, pode também oxidar enzimas, rompendo ligações sulfídricas e sulfúricas nas mesmas, provocando alterações bioquímicas e podendo levar a morte.

Segundo Monarca et al. (2002a) e Monarca et al. (2002b), os subprodutos formados pelo ácido peracético são basicamente ácidos carboxilícos, sendo encontrados também alguns álcoois 
não halogenados e compostos de carbonil que não são reconhecidos como mutagênicos. Porém, como já foi mencionado anteriormente, os efeitos tóxicos decorrentes de desinfecção podem ser causados não só pelos subprodutos de desinfetantes como também pelos seus residuais.

De acordo com Daniel (2001), efluentes desinfetados com ácido peracético indicaram elevada toxicidade para alguns organismos aquáticos (Daphnia similis, Brachidanio rerio e Photobacterium phosphorium). Em um estudo mais recente, Buschini et al. (2004) verificaram, através do teste do cometa, que o ácido peracético foi capaz de induzir genotoxicidade em leucócitos humanos expostos a 1 hora de tratamento em concentrações iguais e superiores a 0,5 $\mathrm{mg} / \mathrm{L}$.

Portanto, apesar de Baldry et al. (1995) afirmarem que o ácido peracético apresenta excelentes propriedades anti-microbianas, ainda se faz necessário um estudo mais aprofundado sobre seu potencial tóxico em diferentes efluentes secundários no Brasil a fim de garantir proteção aos ambientes aquáticos receptores, caso a utilização deste desinfetante seja priorizada.

\subsubsection{Radiação Ultravioleta}

A radiação ultravioleta foi reconhecida como método de desinfecção ainda no final do século XIX, porém, sua aplicação desapareceu com a evolução das técnicas de cloração. Atualmente, a radiação ultravioleta tem ressurgido como uma importante alternativa na desinfecção de esgotos domésticos, não só devido aos problemas de toxicidade de efluentes relacionados a cloração, mas também pelo desenvolvimento da sua tecnologia que tem gerado mais confiabilidade nos equipamentos e tem tornado os custos de operação e manutenção mais competitivos (SPELLMAN, 1999).

A luz ultravioleta é muito efetiva na destruição de vírus e bactérias. Seu comprimento de onda está situado na faixa de 40 a 400nm, entre os raios X e a luz visível, sendo que o seu maior efeito bactericida é obtido entre 250 e $270 \mathrm{~nm}$.

A desinfecção com luz ultravioleta utiliza a energia elétrica para promover a inativação de microorganismos, pois a radiação é geralmente obtida por meio de lâmpadas especiais de vapor de mercúrio ionizado de baixa e média pressão e com diversos valores de potência (DANIEL, 2001). Como estes arcos de lâmpada emitem essencialmente luz monocromática com comprimento de onda de 253,7nm, os mesmos são bastante efetivos na eliminação dos microorganismos (USEPA, 1999b).

A efetividade do processo de desinfecção com UV depende da intensidade de luz emitida, do tempo de contato e da qualidade do efluente (principalmente: densidade inicial de bactérias, turbidez e concentração de sólidos totais em suspensão, que podem ocultar os microorganismos da 
radiação, impedindo sua inativação). Portanto a dose de luz UV (produto da intensidade de radiação pelo tempo de exposição) a ser aplicada irá depender das características do esgoto a ser tratado, sendo que doses muito baixas podem não inativar alguns organismos mais resistentes e podem provocar um efeito sub-letal sobre outros microorganismos, favorecendo a sua fotorreativação.

Por ser uma radiação eletromagnética, o mecanismo de inativação dos microorganismos se dá por meio físico, através da indução de alterações fotobioquímicas dentro das células. As reações de fotólise (quebra das moléculas por ação da luz) só ocorrem se a radiação gera suficiente energia para alterar as ligações químicas das células e se a radiação é absorvida pelas moléculas-alvo. Como os ácidos nucléicos e as proteínas absorvem muito efetivamente a radiação ultravioleta, principalmente nos comprimentos de onda de 240 a 260nm, estes são os principais componentes da célula a serem atingidos durante a desinfecção (TASK FORCE ON WASTEWATER DISINFECTION, 1996).

Acredita-se que a maior parte do dano causado pelo UV ocorre nas bases nitrogenadas que compõe os ácidos nucléicos. Estas bases, chamadas de nucleotídeos, são derivadas da purina (adenina e guanina) ou da pirimidina (citosina e timina ou uracil, no caso de RNA). A radiação UV induz a formação de dímeros entre duas pirimidinas adjacentes numa tira de polinucleotídeos, sendo que o dímero timina-timina é formado com maior eficiência. Os dímeros impossibilitam a replicação do DNA, o que acaba sendo letal para a célula (CAMACHO, 1995).

Acredita-se que a desinfecção com UV, por ser um processo físico, é ambientalmente segura, pois não forma subprodutos nem apresenta residual. No entanto, compostos que absorvem a radiação ultravioleta e apresentam alto rendimento quântico de fotólise têm alto potencial para se fotodegradar, podendo, inclusive, se transformar em compostos mais tóxicos do que os originais (efeito de foto-ativação).

Um fenômeno de foto-ativação que não está relacionado com a água, porém é muito conhecido em regiões altamente industrializadas, é a formação do smog oxidante (smoke, fumaça + fog, neblina) a partir de reações fotoquímicas de produtos de combustão incompleta e compostos orgânicos, resultantes de motores de automóveis, com óxidos de nitrogênio, sob a incidência da luz ultravioleta.

Nipper \& Carr (2002) afirmam que um fator de importância em ambientes aquáticos é o efeito dos raios ultravioleta da luz solar sobre a persistência e toxicidade de alguns compostos orgânicos. Estes autores analisaram o efeito da irradiação solar sobre a fotodegradação e toxicidade foto-induzida (fotoativação) de dois compostos nitroaromáticos (ácido pícrico e 2,6-DNT) em águas marinhas e descobriram que o produto de foto-transformação do 2,6 DNT foi menos tóxico a zoósporos da macroalga Ulva fasciata do que o composto original, porém foi mais tóxico a gametas de equinodermos, indicando foto-ativação. 
Porém, Sampaio (1985) afirma que as dosagens de radiação ultravioleta normalmente empregadas para a desinfecção de águas residuárias são tão pequenas que se pode considerar que seus efeitos sobre as substâncias químicas presentes no efluente são insignificantes, com relação à formação de novos compostos através de reações fotoquímicas. Oliver \& Carey (1976) apud Sampaio (1985) confirmaram esta afirmação através de testes de toxicidade aguda com a truta arcoíris. Estes peixes, expostos por um período de 96 horas a um efluente desinfetado com radiação ultravioleta, não sofreram efeito deletério. No entanto, mais recentemente, Gjessing \& Kallqvist (1991) verificaram que amostras de água contendo substâncias húmicas desinfetadas com luz UV produziram efeito tóxico na alga unicelular Selenastrum capricornutum.

Desta forma, apesar das vantagens da utilização da radiação UV como desinfetante de efluentes domésticos (maior eficiência em mínimo tempo de contato quando comparado a outros agentes de desinfecção, baixo custo de operação e manutenção), ainda se faz necessário verificar o seu potencial tóxico sobre diferentes organismos aquáticos como forma de prevenção a um eventual dano ambiental quando da sua aplicação.

\subsection{Toxicologia}

Toxicologia é a ciência que estuda os efeitos nocivos decorrentes das interações de substâncias químicas ou agentes físicos com o organismo. Tem por objeto de estudo a intoxicação sob todos os seus aspectos e por finalidade primordial a promoção de condições seguras de convívio entre os agentes tóxicos e os organismos vivos, mormente o homem (CHAZIN; PEDROZO, 2003).

A Ecotoxicologia, como ramo da Toxicologia Tradicional, é uma ciência multidisciplinar que objetiva proteger o ecossistema como um todo, avaliando, a partir de parâmetros ecológicos (ensaios de toxicidade a um ou mais componentes do ecossistema), os efeitos dos poluentes no ambiente, levando em consideração a interação existente entre o agente tóxico e o ambiente físico no qual os organismos habitam (HOFFMAN et al., 1995).

O termo "ecotoxicologia" foi proposto em 1969 pelo professor René Truhaut, do Centro de Pesquisas Toxicológicas da Universidade René Descartes, Paris, França, referindo-se à ciência que procura estudar como os ecossistemas metabolizam, transformam, degradam, eliminam ou acumulam, isto é, como se comportam quando sujeitos a ação tóxica de substâncias químicas, naturais ou produzidas pelo homem.

Nesse sentido, na ecotoxicologia tenta-se estudar os efeitos adversos de substâncias tóxicas em qualquer nível de organização de sistemas biológicos (de subcelular até comunidades e ecossistemas), avaliando também os processos de recuperação da biota quando há diminuição da exposição dos agentes tóxicos (RAND et al., 1995). Segundo os autores, ela trata dos efeitos que 
podem provocar alterações tanto negativas como positivas das circunstâncias existentes em determinado momento, mas enfoca principalmente os efeitos adversos e que deveriam cessar assim que a exposição aos agentes tóxicos terminasse.

Nos estudos de ecotoxicidade o principal instrumento é o bioensaio, o qual pode ser conduzido de diversas formas, podendo ser avaliados diferentes processos e efeitos de contaminação a fim de buscar as respostas mais rápidas, precisas e de fácil interpretação.

Os métodos de ensaio de toxicidade incluem testes agudos, crônicos, de bioacumulação, biodegradação e biomarcação (RAND; PETROCELLI, 1985), podendo ter como endpoint (efeito biológico que é medido e aceito como indicador da toxicidade da substância testada) modificações comportamentais, fisiológicas e de letalidade, assim como alterações bioquímicas, genéticas ou teratogênicas. Os bioensaios podem ser realizados sob condições controladas, tanto em laboratório como em campo.

Dentre os testes mais frequentemente utilizados em laboratório, os bioensaios agudos ocupam posição de destaque devido a sua maior simplicidade e ao curto período de exposição dos organismos ao agente tóxico. Normalmente, o endpoint é a letalidade (para peixes), imobilização (para invertebrados), crescimento (para alga), etc. A resposta geralmente é dada em termos de CL50 (Concentração Letal Média, isto é, a concentração do agente tóxico que causa efeito agudo letal a $50 \%$ dos organismos-teste, num período de exposição determinado) ou CE50 (Concentração Efetiva Média, isto é, a concentração do agente tóxico que causa efeito agudo não letal a $50 \%$ dos organismos-teste, num determinado período de exposição). O bioensaio é realizado, preferencialmente, no período de vida mais sensível do organismo-teste.

Os testes crônicos também são muito utilizados, pois apresentam respostas mais sensíveis ao agente tóxico, sendo realizados durante um período mais prolongado de tempo. Nesse caso, os organismos são expostos continuamente aos contaminantes, geralmente em menores concentrações, por uma determinada etapa do ciclo de vida da espécie (envolvendo alguns estágios mais sensíveis do organismo-teste) ou por todo o seu ciclo. Podem ocorrer mortes, porém, o principal objetivo desses testes é estabelecer concentrações ambientalmente seguras observando efeitos na reprodução, desenvolvimento, fertilidade, comportamento, além de alterações fisisiológicas e bioquímicas. A resposta pode ser dada em termos do CENO (Maior Concentração de Efeito Não Observado) ou CEO (Menor Concentração de Efeito Observado), sendo que o Valor Crônico (média geométrica dos valores de CENO e CEO) pode ser estimado.

O método do teste de toxicidade a ser empregado, bem como os organismos-teste a serem utilizados e os efeitos passíveis de serem observados (endpoints), devem ser escolhidos de acordo com os objetivos do estudo. Caso o foco da pesquisa seja comparar o efeito tóxico de uma substância em relação à outra, um protocolo operacional rígido de testes é mais apropriado, sendo 
necessária a utilização de organismos cuja metodologia de testes já esteja padronizada, podendo ser considerado inclusive o uso de um organismo-teste alóctone. Porém, caso pretenda-se descrever o comportamento de uma mistura complexa em um sistema específico, pode ser mais vantajoso adaptar a metodologia de teste às necessidades do estudo, conduzindo o ensaio sob condições físicas e químicas características daquele ambiente e utilizando um organismo autóctone com maior representatividade ecológica.

Segundo Guckert (1996) apud Gusmão (2004), as avaliações de toxicidade são, na maioria das vezes, conduzidas utilizando apenas uma espécie de organismo-teste, a qual deve ser capaz de representar todas as outras espécies do ambiente por ser indicadora sensível dos efeitos das substâncias tóxicas. Porém, em função da multiplicidade de espécies existentes no ambiente, das inúmeras relações de dependência entre elas e da variedade de efeitos adversos que agentes tóxicos podem causar em diferentes espécies, preconiza-se que os testes sejam realizados com, no mínimo, três organismos pertencentes a diferentes níveis tróficos, de modo a obter o resultado com o organismo mais suscetível e estimar com maior segurança o impacto causado pelo toxicante (AZEVEDO; CHASIN, 2003). 


\section{JUSTIFICATIVA}

A desinfecção de esgotos sanitários, apesar de não ser obrigatória, em muitos casos é necessária na medida em que garante a qualidade microbiológica do corpo d'água receptor e permite o seus múltiplos usos por parte da população.

Quando um efluente doméstico é lançado no ambiente aquático sem ser previamente desinfetado, ocorre um decréscimo natural dos organismos patogênicos ao longo do tempo devido à diluição, porém, principalmente nos centros urbanos, os grandes volumes de esgotos gerados e a multiplicidade de locais de descargas de águas residuárias tornam insuficiente a redução natural de patógenos no corpo hídrico receptor.

Ademais, a crescente deterioração das fontes de abastecimento de água para consumo humano, o gradativo aumento populacional e conseqüente incremento de demanda hídrica impõem a necessidade de reúso dos efluentes para fins mais nobres, como recreação, irrigação e aquicultura.

Cabe ressaltar que nas últimas três décadas a irrigação com efluentes sanitários tornou-se prática crescente em todo o mudo, por vezes acompanhada de rígido controle sanitário, outras não. A utilização controlada de esgotos sanitários em irrigação, hidroponia e piscicultura já vem sendo praticada em diversos países, sendo inclusive regulamentada em legislação específica em países como México e Israel. No Brasil, apesar de não haver regulamentação específica, já se reconhece a prática disseminada do reúso de esgotos para irrigação (BASTOS et al., 2003). Porém, considerando que na maioria das estações de tratamento de esgotos no País inexistem processos de desinfecção, o uso indiscriminado das águas residuárias impõe sérios riscos à saúde da população.

Diante desse fato, atualmente, o interesse na desinfecção de esgotos sanitários é cada vez maior. Porém, a desinfecção dos esgotos sanitários após o tratamento deve ser estudada caso a caso. Devido ao potencial de causar efeitos deletérios ao ambiente receptor, o uso de desinfetantes convencionais, como o cloro, por exemplo, tem sido motivo de grandes preocupações. Certamente o risco de infecção humana por microorganismos patogênicos deve ser priorizado, mas os impactos ambientais decorrentes da desinfecção também precisam ser levados em consideração.

Vários pesquisadores já compararam a eficiência de desinfecção do cloro com desinfetantes considerados alternativos (ozônio, ácido peracético, radiação ultravioleta), e verificaram que estes outros agentes também podem demonstrar habilidade de alterar a toxicidade dos efluentes desinfetados (tabela 2.1). 
Tabela 2.1. Sumário dos efeitos tóxicos de desinfetantes de efluentes domésticos verificados por diferentes autores. ( $\mathrm{S}=$ toxicidade; $\mathrm{N}=$ ausência de toxicidade).

\begin{tabular}{|c|c|c|c|c|c|c|}
\hline $\begin{array}{c}\text { Organismo } \\
\text { Desinfetante }\end{array}$ & $\begin{array}{c}\text { Pimephales } \\
\text { promelas }\end{array}$ & $\begin{array}{c}\text { Ceriodaphnia } \\
\text { dubia }\end{array}$ & $\begin{array}{c}\text { Selenastrum } \\
\text { capricornutum }\end{array}$ & $\begin{array}{c}\text { Bactéria } \\
\text { heterótrofa }\end{array}$ & $\begin{array}{c}\text { Vibrio } \\
\text { fischeri }\end{array}$ & $\begin{array}{l}\text { Allium } \\
\text { cepa }\end{array}$ \\
\hline Cloro & - & S (6) & - & - & S (5) & $\mathrm{N}(5)$ \\
\hline Ozônio & $\mathrm{N}(1)$ & $\mathrm{N}(1) ; \mathrm{S}(2)$ & $\mathrm{N}(1)$ & - & S (5) & $\mathrm{N}(5)$ \\
\hline UV & N (1) & $\mathrm{N}(1) ; \mathrm{S}(2)$ & $\mathrm{N}(1) ; \mathrm{S}(3)$ & S (4) & $\mathrm{N}(5)$ & $\mathrm{N}(5)$ \\
\hline PAA & - & - & - & - & S (5) & $S(5)$ \\
\hline
\end{tabular}

(1) Oppenheimer et al. (1994) apud Blatchley III et al. (1997).

(3) Gjessing \& Kallqvist (1991)

(5) Monarca et al. (2000)

(2) Blatchley III, et al. (1997)

(4) Lund \& Hongve (1994)

(6) Thompson \& Blatchley III (1999)

Ao selecionar um desinfetante de esgoto sanitário visando a segurança microbiológica dos corpos hídricos receptores, é importante, tanto do ponto de vista econômico, como de saúde pública e de qualidade ambiental, estar consciente sobre o risco de formação de subprodutos potencialmente tóxicos e sobre a persistência do residual de desinfecção. Estudos demonstram que a velocidade de formação de qualquer subproduto, assim como sua concentração final, está altamente relacionada com os parâmetros de qualidade do efluente desinfetado (incluindo $\mathrm{pH}$, temperatura, carga orgânica, concentração de amônia e íons brometo, etc.), com o tempo de contato entre o desinfetante e o efluente e com a concentração de residual dos desinfetantes.

Como os efluentes sanitários apresentam características químicas, físicas e microbiológicas distintas entre si, tanto espacialmente como temporalmente, a demanda de desinfetante necessária para promover a inativação de microorganismos patogênicos em um dado momento e em uma dada localidade é diferente, assim como seu eventual potencial tóxico. Sendo assim, a aplicação do desinfetante não pode se dar de forma aleatória, sem um estudo preliminar.

De acordo com Dias (2001), a escolha de um desinfetante tem por objetivo obter máxima eficiência e confiabilidade na desinfecção com o menor custo e mínimos efeitos indesejáveis sobre o efluente a ser tratado e sobre o ambiente receptor. Consequentemente, durante a desinfecção, o ideal seria utilizar a menor concentração do agente químico capaz de promover a inativação dos microorganismos indesejados, de forma a liberar menores concentrações de residual e formar menores quantidades de subprodutos.

Nesse sentido, a escolha de um processo de desinfecção de águas residuárias deve preconizar a investigação de diferentes desinfetantes em diversas dosagens e tempos de contato, não só com o objetivo de avaliar a eficiência da desinfecção como também de verificar seu potencial tóxico sobre a vida aquática. 
Para avaliar os efeitos adversos que a desinfecção de esgoto sanitário pode causar na biota dos corpos hídricos receptores, pode-se lançar mão de estudos ecotoxicológicos, cuja ferramenta principal é o bioensaio de toxicidade.

Os bioensaios baseiam-se fundamentalmente na exposição de organismos-teste prédefinidos (sejam eles representativos do ambiente em questão ou que apresentem metodologia de testes padronizada) à várias concentrações de uma ou mais substâncias, misturas químicas complexas ou à amostras ambientais, por um período de tempo determinado.

Os bioensaios são especialmente importantes para avaliar a toxicidade de misturas complexas, como é o caso do efluente desinfetado, na medida em que essas misturas são constituídas por uma infinidade de substâncias de difícil identificação. Ademais, há que se considerar as inúmeras interações que ocorrem entre os compostos químicos presentes nos efluentes e os desinfetantes, resultando nas mais diferentes formas de ação sobre o organismos expostos e que, muitas vezes, não podem ser quantificados por meio de análises químicas.

Cumpre ainda ressaltar que a expressão da toxicidade de uma substância química ou mistura complexa depende das características da exposição e de seu comportamento no meio ambiente e no sistema biológico. Além das propriedades físico-químicas da substância ou mistura complexa, devese considerar a magnitude, a duração e a freqüência da exposição, as vias de introdução, a natureza do endponit do tóxico que está sendo medido, as espécies testadas e a suscetibilidade dos organismos, estando esta última diretamente interligada aos processos toxicocinéticos e toxicodinâmicos (AZEVEDO; CHASIN, 2003; USEPA, 1989).

Pretendeu-se, neste trabalho, avançar no conhecimento sobre o potencial efeito tóxico de diferentes agentes de desinfecção de efluente de tratamento secundário de esgoto sanitário. Trata-se, portanto, de um estudo experimental, onde se buscou avaliar a eficiência de três tipos de agentes químicos (hipoclorito de sódio, ozônio e ácido peracético) e um agente físico (radiação ultravioleta) na inativação de coliformes totais e Escherichia coli presentes no esgoto doméstico proveniente da Estação de Tratamento de Esgotos (ETE) da cidade de Araraquara (SP). Porém, principalmente, procurou-se verificar se esses desinfetantes, após aplicados no esgoto sanitário, apresentaram residuais persistentes ou formaram subprodutos que pudessem ser tóxicos aos cinco organismosteste utilizados nos bioensaios, os quais representam diferentes níveis da cadeia trófica de um ambiente aquático.

Ressalta-se que a interpretação e extrapolação dos dados obtidos nos ensaios de toxicidade devem permitir identificar os limites seguros e aceitáveis de contaminação dos esgotos desinfetados, de forma a garantir que seu posterior lançamento no ambiente aquático não prejudique a saúde dos corpos hídricos receptores. 


\section{OBJETIVOS}

O objetivo principal deste estudo foi o de avaliar o potencial tóxico de diferentes desinfetantes (hipoclorito de sódio, ácido peracético, radiação ultravioleta e ozônio) que podem ser usados na desinfecção de esgotos sanitários. Para tanto, foram realizados ensaios de desinfecção (diversas concentrações e tempos de contato) com o esgoto doméstico originário da cidade de Araraquara (SP) e, posteriormente, ensaios de toxicidade a fim de verificar possíveis efeitos agudos e crônicos em diferentes organismos-teste (Daphnia similis, Ceriodaphnia silvestrii, Chironomus xanthus, Danio rerio e Allium cepa).

Os objetivos secundários incluem:

- Caracterizar o esgoto sanitário bruto quanto às suas propriedades físicas, químicas e bacteriológicas;

- Verificar o potencial tóxico do esgoto sanitário após tratamento secundário.

- Verificar possíveis alterações nas características físicas, químicas e bacteriológicas do esgoto sanitário após a desinfecção com cada agente desinfetante;

- Classificar os agentes desinfetantes utilizados na desinfecção do esgoto sanitário de acordo com seu grau de toxicidade aos organismos-teste, levando-se em consideração as diferentes concentrações e tempos de contato testadas.

- Determinar qual dos agentes desinfetantes testados apresenta maior efetividade em termos de inativação de coliformes totais e Escherichia coli e menor potencial tóxico aos organismos-teste e, portanto, qual seria mais indicado para ser utilizado na desinfecção do do efluente de tratamento secundário do esgoto sanitário de Araraquara (SP), de forma a minimizar os impactos ao corpo hídrico receptor.

\section{HIPÓTESE DO TRABALHO}

A hipótese fundamental deste estudo baseia-se no fato de que "alguns agentes desinfetantes, apesar de promoverem redução dos microorganismos patogênicos presentes no esgoto sanitário, também podem produzir compostos tóxicos e genotóxicos, dependendo dos precursores existentes no efluente e das doses dos desinfetantes" (MONARCA et al., 2000). Por isso, quando se pretende implantar um sistema de desinfecção em uma Estação de Tratamento de Esgotos de uma determinada localidade, é prudente que se faça um estudo toxicológico prévio analisando o potencial tóxico de formas convencionais e alternativas de desinfetantes, de forma que se possa adotar o agente desinfetante mais adequado e eficaz àquele determinado efluente, o que minimizaria possíveis efeitos adversos ao corpo hídrico receptor e a sua biota. 


\section{MATERIAIS E MÉTODOS}

Este trabalho, de cunho experimental, foi desenvolvido no Laboratório de Ecotoxicologia e Ecofisiologia de Organismos Aquáticos, pertencente ao Núcleo de Estudos de Ecossistemas Aquáticos (NEEA), localizado no Centro de Recursos Hídricos e Ecologia Aplicada (CRHEA), em Itirapina, SP, o qual faz parte do Departamento de Hidráulica e Saneamento (SHS), da Escola de Engenharia de São Carlos (EESC), Universidade de São Paulo (USP).

\section{1. Área de coleta}

Para o desenvolvimento do presente estudo, optou-se por utilizar as águas residuárias provenientes da Estação de Tratamento de Esgotos (ETE) de Araraquara (SP), uma vez que não havia ETE em São Carlos durante a fase experimental deste trabalho.

O município de Araraquara (SP), que está localizado a cerca de 40km de São Carlos, possui uma área total de $1.312 \mathrm{~km}^{2}$ e aproximadamente 190 mil habitantes.

A Estação de Tratamento de Esgotos Sanitários de Araraquara (ETE-Araraquara), que foi inaugurada em março de 2000 e é operada pelo Departamento Autônomo de Água e Esgotos (DAAE), situa-se às margens do Ribeirão das Cruzes, na Rodovia SP 255, a 13km do perímetro urbano. Essa Estação foi planejada para atender uma população de 270 mil habitantes, possuindo capacidade total de tratamento de 800 1/s. Atualmente a ETE-Araraquara trata 100\% dos esgotos sanitários coletados na cidade. Sua rede de esgotos, formada por $893 \mathrm{~km}$ de coletores, atende a mais de $98 \%$ dos estabelecimentos municipais de Araraquara.

O sistema de tratamento da ETE-Araraquara é de nível secundário, sendo constituído por lagoas de estabilização que apresentam dois módulos em paralelo. Cada módulo é composto por Lagoa de Aeração, Lagoa de Sedimentação e Lagoa de Lodo, como pode ser observado na figura 5.1. O processo de desinfecção não faz parte do sistema de tratamento dessa ETE.

No tratamento preliminar (físico), o resíduo bruto que chega na Estação por meio de emissário subterrâneo é submetido a um gradeamento inicial para a separação dos detritos maiores (figura 5.2). Posteriormente, o esgoto atravessa uma calha Parshal, que registra a vazão de esgoto a ser tratado, e segue para as caixas retentoras de areia, cuja função é separar a areia do líquido que seguirá para o tratamento nas Lagoas. 


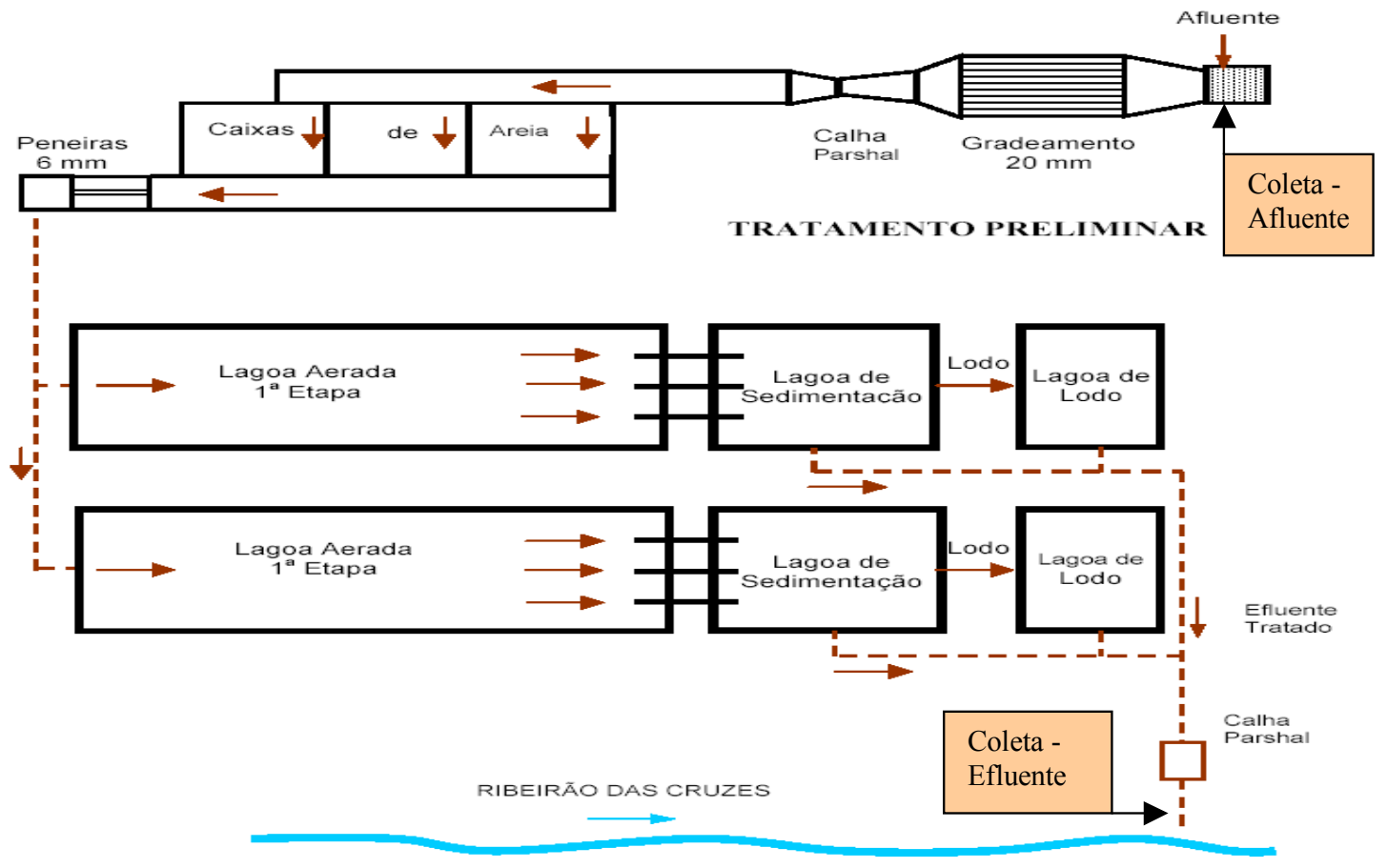

Figura 5.1. Fluxograma da ETE - Araraquara. ${ }^{1}$

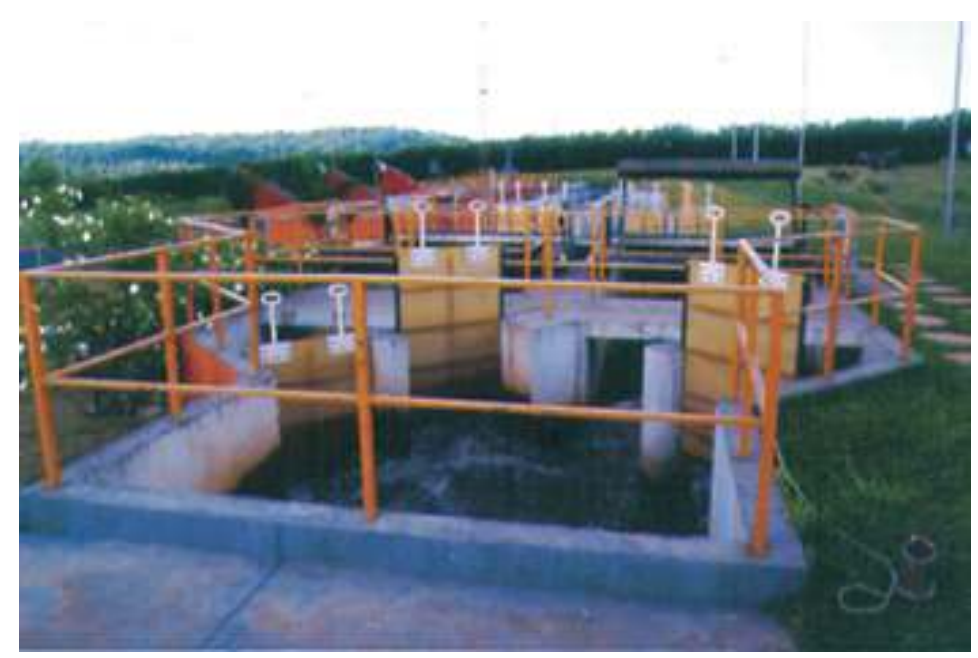

Figura 5.2. Chegada do esgoto bruto por tubulação submersa à ETE-Araraquara (Tratamento Preliminar). ${ }^{1}$

O tratamento biológico ocorre nas Lagoas de Aeração, onde o esgoto é submetido à agitação mecânica realizada por aeradores (figura 5.3). Esses equipamentos movimentam a água promovendo a oxigenação da mistura, eliminando gases indesejáveis e acelerando o processo de decomposição da matéria orgânica por bactérias aeróbias. O volume útil das Lagoas de Aeração é 
da ordem de $103.700,00 \mathrm{~m}^{3}$, o que implica em um tempo de detenção médio do esgoto de 3 dias nessas lagoas, considerando a vazão nominal média de 400L/s por módulo.

Em seguida, o esgoto é encaminhado para as Lagoas de Sedimentação, onde permanece em descanso para que as partículas sólidas ainda presentes na mistura se depositem no fundo das lagoas (figura 5.4). Esse processo de sedimentação remove a matéria orgânica da coluna d'água transformando-a em biomassa (lodo). O volume útil dessas lagoas é da ordem de $57.600,00 \mathrm{~m}^{3}$, proporcionando um tempo de detenção médio de 1,7 dias, considerando a vazão nominal média de cada módulo de $400 \mathrm{~L} / \mathrm{s}$.

O lodo sedimentado no fundo das lagoas deve ser estabilizado por processos anaeróbios na Lagoa de Lodo e removido periodicamente para um aterro sanitário; porém, até o término da fase experimental deste estudo, a Lagoa de Lodo ainda não se encontrava em operação, devido ao fato do lodo ainda não ter sido formado em quantidade suficiente durante todo o período de funcionamento da ETE-Araraquara.

Ao sair da Lagoa de Sedimentação, o efluente líquido final não é submetido a nenhum sistema de desinfecção, sendo lançado diretamente no Ribeirão das Cruzes (figura 5.5). Esse rio, que atravessa a zona urbana de Araraquara, está inserido na Bacia do rio Jacaré-Guaçú (Médio Tietê Inferior - UGRHI Tietê/Jacaré) e é enquadrado, de acordo com o Decreto Estadual n 39.173/94, como rio de classe 4 .

Apesar de as águas do Ribeirão das Cruzes estarem destinadas aos seus usos menos exigentes, como navegação e harmonia paisagística, conforme classificação estabelecida pelo CONAMA (Resolução No 357 de 17 de março de 2005), podem ser encontradas represas às suas margens utilizadas no meio rural para fins como a irrigação de pomares e canaviais.

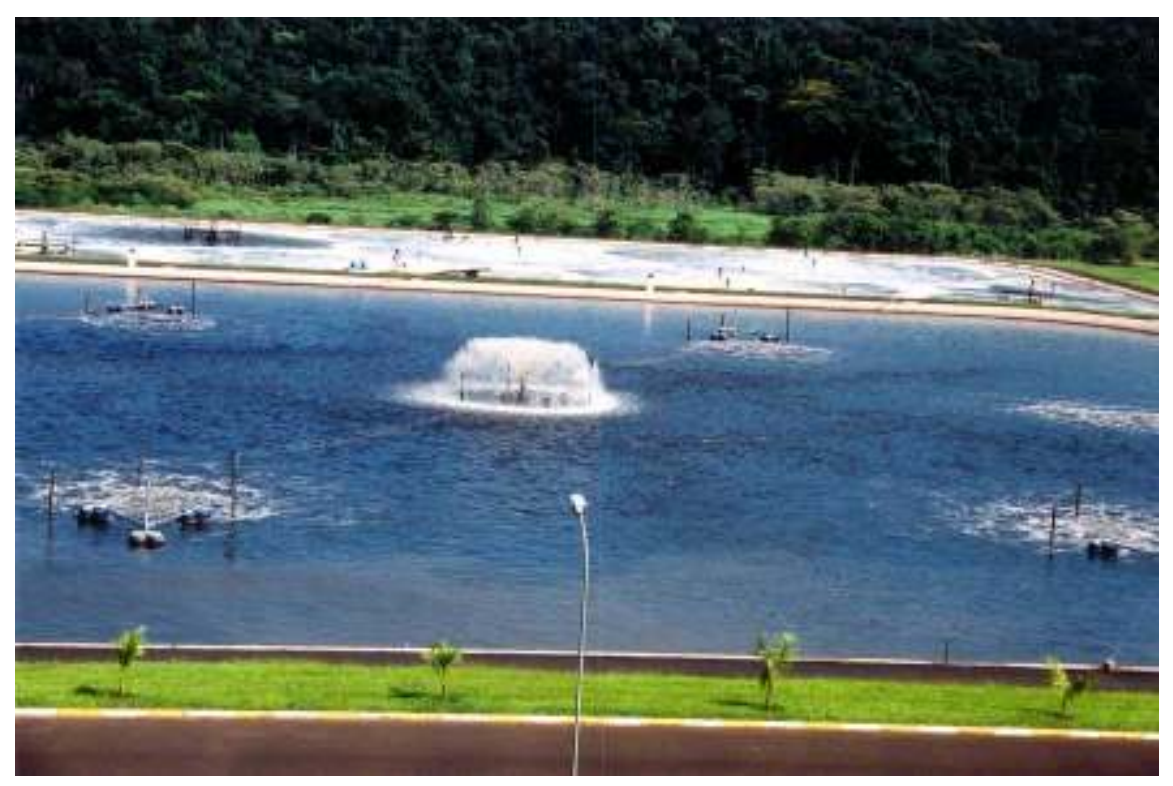

Figura 5.3. Lagoas de Aeração da ETE-Araraquara. ${ }^{1}$ 


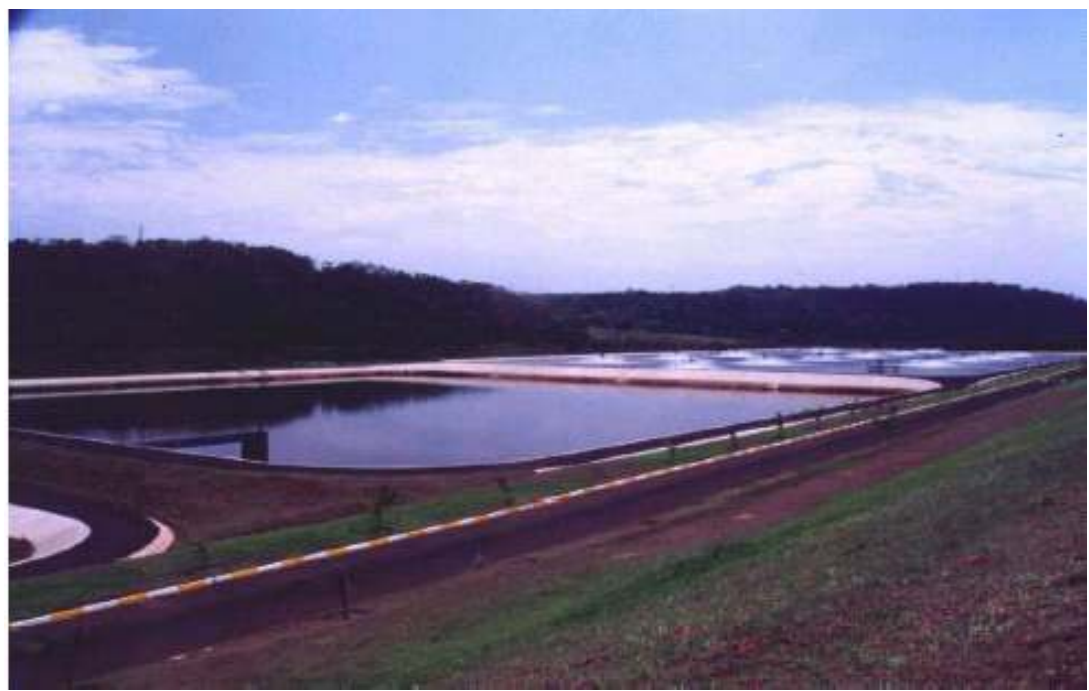

Figura 5.4. Lagoas de Aeração (ao fundo) e de sedimentação (à frente) da ETE-Araraquara. ${ }^{1}$

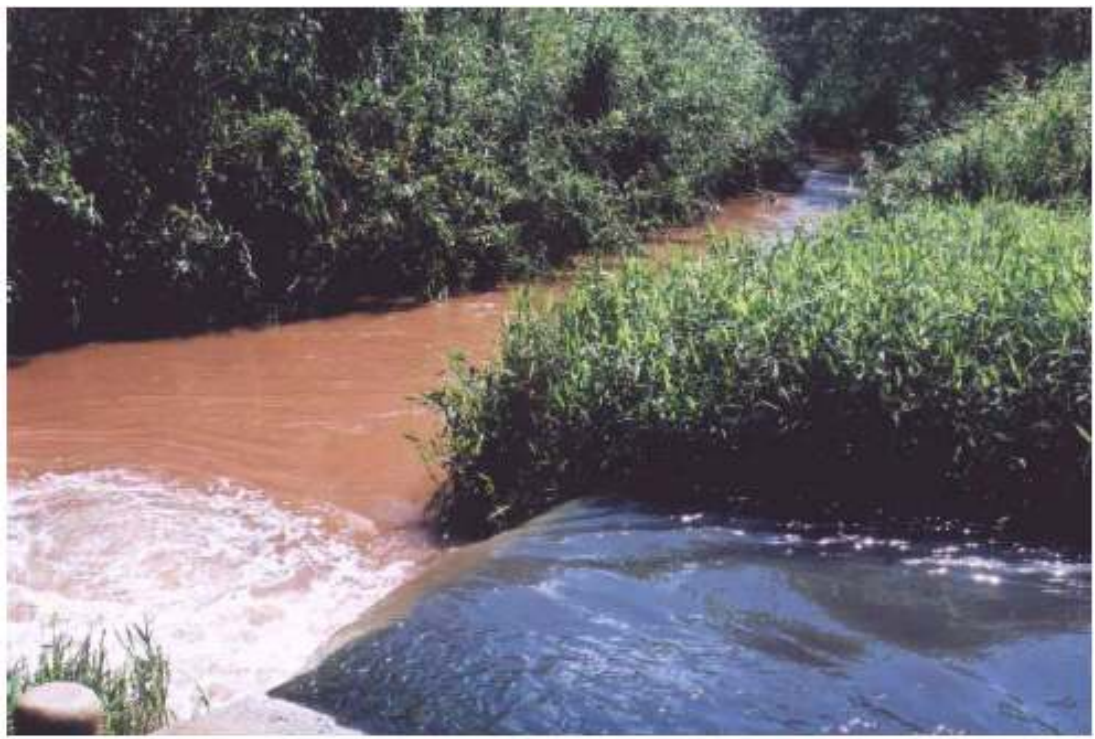

Figura 5.5. Efluente final da ETE-Araraquara sendo lançado no Ribeirão das Cruzes. ${ }^{1}$

\footnotetext{
Fonte: SCALIZE, P. S. et al. (2003).
} 


\subsection{Coleta, transporte e estocagem das amostras}

Neste estudo, foram realizadas quatro coletas instantâneas de esgoto na ETE-Araraquara. A primeira coleta, considerada preliminar, foi efetuada em setembro de 2003. Nessa oportunidade, foram amostrados 40L de esgoto bruto (antes de ser submetido ao gradeamento inicial - figura 5.2) e 40L de esgoto tratado (antes de ser lançado no Ribeirão das Cruzes - figura 5.5).

$\mathrm{O}$ objetivo dessa primeira coleta foi o de analisar as características físicas, químicas e bacteriológicas gerais do esgoto sanitário bruto (afluente da ETE) e tratado (efluente da ETE) de Araraquara e estimar seu potencial tóxico a diferentes organismos-teste. Não foram realizados ensaios de desinfecção nesse momento.

As outras coletas foram efetuadas em abril, julho e novembro de 2004, quando foram amostrados, em cada ocasião, 60L do esgoto tratado para a realização de ensaios de desinfecção, testes de toxicidade e caracterização física, química e bacteriológica do efluente.

Todas as coletas foram realizadas durante o período matutino (entre $8 \mathrm{~h} 30 \mathrm{~min}$ e $10 \mathrm{~h}$ ), sendo as amostras transportadas em galões de plástico de 20L até o laboratório, onde uma fração foi armazenada em geladeira a $4^{\circ} \mathrm{C}$ para posterior realização das análises físicas e químicas e outra alíquota foi diretamente utilizada em ensaios de desinfecção e testes de toxicidade.

\subsection{Variáveis hidrológicas da ETE-Araraquara: vazão}

As medidas de vazão do esgoto bruto e tratado da ETE-Araraquara foram obtidas junto ao DAAE, no momento de cada coleta, e foram expressas em $\mathrm{L} / \mathrm{s}$.

\subsection{Variáveis químicas, físicas e bacteriológicas do esgoto}

Após a coleta do efluente, o mesmo foi caracterizado quanto a sua concentração de nutrientes, sulfetos, sulfatos e cloretos, metais totais, sólidos totais (dissolvidos e em suspensão), carga orgânica (demanda bioquímica de oxigênio, demanda química de oxigênio e carbono orgânico total), oxigênio dissolvido, alcalinidade, dureza, $\mathrm{pH}$, condutividade e absorbância a $254 \mathrm{~nm}$.

Como parâmetros bacteriológicos, coliformes totais e Escherichia coli foram utilizados para avaliação da eficiência dos sistemas de desinfecção, sendo realizados, portanto, exames no efluente não desinfetado e desinfetado.

As metodologias específicas utilizadas para a determinação das variáveis químicas, físicas e bacteriológicas do esgoto, com exceção dos nutrientes, tiveram como referência APHA (1998). 


\subsubsection{Nutrientes}

Neste estudo, foram analisadas as concentrações de formas nitrogenadas (nitrogênio total Kjeldhal, amônia, nitrito e nitrato) e fosfatadas (fósforo total, fosfato total dissolvido e fosfato inorgânico dissolvido), bem como de silicato reativo, presentes nas amostras de efluente da ETEAraraquara.

Em laboratório, logo após as coletas, alíquotas de aproximadamente $200 \mathrm{~mL}$ de amostras homogeneizadas foram armazenadas e congeladas em frascos de polietileno para posterior análise de nitrogênio orgânico total e fósforo total.

Para a análise dos outros nutrientes, frações de aproximadamente $500 \mathrm{~mL}$ de cada amostra foram filtradas em membranas de fibra de vidro GF/C WHATMAN, de 0,45 $\mu \mathrm{m}$ de porosidade, sendo congeladas em frascos de polietileno até sua determinação.

A metodologia específica para a determinação de cada nutriente é apresentada na tabela 5.1, sendo a colorimetria utilizada em todos os casos. Com exceção no nitrogênio total Kjeldhal, cuja medida é dada por titulometria, as concentrações dos outros nutrientes foram medidas por espectrofotômetro de transmissão modelo "SHIMADZU UV - 2101PC", seguindo os padrões estabelecidos pelo Laboratório de Limnologia do NEEA/CRHEA.

Tabela 5.1. Metodologias de análise de nutrientes utilizadas no presente estudo e capacidade de detecção de cada método.

\begin{tabular}{|l|c|c|}
\hline \multicolumn{1}{|c|}{ Variável } & Referências de Metodologias & Faixa de Detecção \\
\hline Nitrogênio Total Kjeldhal & Golterman et al (1978) & 1 a 100mg/L \\
\hline Nitrito & Golterman et al $(1978)$ & 0,01 a $1,0 \mathrm{mg} / \mathrm{L}$ \\
\hline Nitrato & Mackereth et al. $(1978)$ & 0,01 a $1,0 \mathrm{mg} / \mathrm{L}$ \\
\hline Amônia & Koroleff $(1976)$ & 0,02 a $2,0 \mathrm{mg} / \mathrm{L}$ \\
\hline Fósforo total & Strickland \& Parsons $(1960)$ & 0,01 a 6,0mg/L \\
\hline Fosfato total e inorgânico dissolvidos & Strickland \& Parsons $(1960)$ & 0,01 a $6,0 \mathrm{mg} / \mathrm{L}$ \\
\hline Silicato reativo & Golterman et al. $(1978)$ & 0,4 a $25 \mathrm{mg} / \mathrm{L}$ \\
\hline
\end{tabular}

Dada a grande concentração de determinados nutrientes nos efluentes testados, houve casos em que ocorreu extrapolação da capacidade de detecção dos respectivos métodos de análises. Nessas situações, conforme recomendado por APHA (1998), foi necessário diluir as amostras com água destilada e deionizada para que suas medidas se adequassem aos limites de concentração específicos do método selecionado, sendo seus valores ajustados posteriormente. 


\subsubsection{Sulfetos}

Em laboratório, alíquotas de $25 \mathrm{~mL}$ de amostras de esgoto foram utilizadas para a determinação de sulfetos totais. Foi adotado o método colorimétrico azul de metileno, o qual é adequado para detectar concentrações de 0,1 a $20 \mathrm{mg} / \mathrm{L}$. A leitura foi realizada em espectrofotômetro modelo DR/2000, marca HACH.

\subsubsection{Sulfatos}

Amostras homogeneizadas de esgoto foram mantidas sob refrigeração a $4^{\circ} \mathrm{C}$ para posterior análise de sulfatos. Foi realizada a análise adicionando-se o conteúdo de uma embalagem do reagente de SulfaVer 4 Sulfate a $25 \mathrm{~mL}$ de amostra, sendo a leitura efetuada em espectrofotômetro $\mathrm{DR} / 2000$, marca HACH. Esse método pode ser aplicado para amostras que contenham concentrações de sulfatos entre 20 e $70 \mathrm{mg} / \mathrm{L}$. Em alguns casos, houve necessidade de diluir as amostras com água destilada e deionizada para que suas medidas se adequassem aos limites de concentração do método, sendo seus valores ajustados posteriormente.

\subsubsection{Cloretos}

Amostras homogeneizadas de esgoto foram mantidas sob refrigeração a $4^{\circ} \mathrm{C}$ para posterior análise de íons cloretos. As concentrações de cloretos foram determinadas pelo método colorimétrico, utilizando solução férrica e solução de mercúrio como reagentes. Esse método é adequado para detectar de 1 a 200mg de $\mathrm{Cl}^{-} / \mathrm{L}$. A leitura foi realizada em espectrofotômetro da marca HACH, modelo DR/2000.

\subsubsection{Metais}

Logo após cada coleta, uma alíquota de $1000 \mathrm{~mL}$ de esgoto foi armazenada em garrafa de polietileno, fixada imediatamente com $1,5 \mathrm{~mL}$ de ácido nítrico $\left(\mathrm{HNO}_{3}\right)$ concentrado e mantida sob refrigeração a $4^{\circ} \mathrm{C}$ até o momento da análise. A preservação da amostra com ácido nítrico é necessária para manter o $\mathrm{pH}$ do efluente abaixo de 2, evitando perdas de metais por volatilização, adsorção ou precipitação nas garrafas.

Para a determinação da concentração total dos metais (chumbo, cromo, cádmio, cobre, zinco, níquel, ferro, manganês, magnésio e cálcio) presentes no esgoto, a metodologia utilizada foi a da digestão com ácido nítrico concentrado, acrescentando-se peróxido de hidrogênio, seguindo as recomendações descritas em APHA (1998). A leitura foi feita em espectrofotômetro de absorção atômica por chama modelo "VARIAN Spectr AA220". 
Os Limites de Deteç̧ão (LD) e Quantificação (LQ) determinados pelo laboratório de Limnologia do NEEA/CRHEA para os metais analisados neste estudo estão apresentados na tabela 5.2 .

Tabela 5.2. Limites de detecção e quantificação para as análises de metais por espectrofotometria de absorção atômica com chama. Fonte: NEEA/CRHEA/SHS/EESC/USP.

\begin{tabular}{|c|c|c|}
\hline Metais & $\mathbf{L D}(\mathbf{m g} / \mathbf{L})$ & LQ $(\mathbf{m g} / \mathbf{L})$ \\
\hline Chumbo & 0,040 & 0,132 \\
\hline Cromo & 0,014 & 0,045 \\
\hline Cádmio & 0,008 & 0,028 \\
\hline Cobre & 0,004 & 0,012 \\
\hline Zinco & 0,014 & 0,048 \\
\hline Níquel & 0,030 & 0,100 \\
\hline Ferro & 0,028 & 0,092 \\
\hline Manganês & 0,010 & 0,030 \\
\hline Magnésio & 0,005 & 0,015 \\
\hline Cálcio & 0,130 & 0,430 \\
\hline
\end{tabular}

Diversos autores orientam para que não sejam realizadas avaliações quantitativas baseadas em concentrações obtidas próximas ao LD, sugerindo que se adote um limiar mais conservador, o LQ.

\subsubsection{Sólidos Totais, Sólidos em Suspensão Totais e Sólidos Dissolvidos Totais}

Os sólidos totais (ST) presentes em uma amostra incluem os sólidos em suspensão totais (SST) - porção dos sólidos retida por um filtro com porosidade igual ou inferior a $2,0 \mu \mathrm{m}$ - e os sólidos dissolvidos totais (SDT) - porção dos sólidos que passa através desse filtro (APHA, 1998).

No presente estudo, as concentrações de ST, SST e SDT, bem como as respectivas frações voláteis e fixas, presentes nas amostras de efluente antes e após cada desinfecção, foram determinadas seguindo metodologias específicas descritas em APHA (op. cit.), as quais são adequadas para detectar concentrações de sólidos de até $20.000 \mathrm{mg} / \mathrm{L}$.

Cabe ressaltar que, para a extração de SST, foram utilizados filtros de fibra de vidro GF/C WHATMAN, com $\mathbf{0 , 4 5} \boldsymbol{\mu m}$ de porosidade, previamente calcinados em mufla e pesados em balança analítica digital "METTLER AE 240", com 0,0001g de precisão. As amostras de esgoto filtradas por essas membranas foram utilizadas para a análise de SDT. 


\subsubsection{Demanda Bioquímica de Oxigênio}

Para a determinação da Demanda Bioquímica de Oxigênio $\left(\mathrm{DBO}_{5}\right)$, em $\mathrm{mg} \mathrm{O}_{2} / \mathrm{L}$, utilizou-se o sistema de diluição e incubação $\left(20^{\circ} \mathrm{C}\right.$ em 5 dias $)$, seguida por análise titulométrica (APHA, 1998). Cabe observar que as análises de $\mathrm{DBO}_{5}$ foram iniciadas até, no máximo, 2 horas após a coleta das amostras de efluente em campo.

\subsubsection{Demanda Química de Oxigênio}

Para a determinação da Demanda Química de Oxigênio (DQO) em amostras homogeneizadas de efluentes não desinfetados e desinfetados, seguiu-se metodologia estabelecida por APHA (1998). Utilizou-se o método colorimétrico, aplicado a amostras digeridas em frascos de reação (tipo $\mathrm{HACH}$ ) fechados, mantidos em termo-reator a $150^{\circ} \mathrm{C}$ por 2 horas. A leitura foi realizada em espectrofotômetro modelo DR/2000. Os reagentes utilizados na digestão das amostras, da marca HACH (High range), apresentam capacidade de detecção de concentrações que variam de 20 a $1.500 \mathrm{mg}$ de $\mathrm{O}_{2} / \mathrm{L}$.

\subsubsection{Carbono Orgânico Total}

As medidas de carbono orgânico total (COT) das amostras de esgoto foram obtidas no próprio DAAE/ETE-Araraquara no momento da coleta. As análises foram efetuadas seguindo metodologia preconizada por APHA (1998) e os resultados foram expressos em mg de C/L.

\subsubsection{Oxigênio Dissolvido}

As concentrações de oxigênio dissolvido (OD) foram medidas pelo método do eletrodo de membrana, utilizando oxímetro da marca Toledo, modelo MO128, e seus resultados foram expressos em $\mathrm{mg} / \mathrm{L}$.

\subsubsection{Alcalinidade}

As medidas de alcalinidade em amostras de esgoto não desinfetado e desinfetado foram determinadas pelo método titulométrico, utilizando ácido sulfúrico padronizado a $0,05 \mathrm{~N}$ e potenciômetro, marca Micronal modelo B374. O resultado foi expresso em termos de mg de $\mathrm{CaCO}_{3} / \mathrm{L}$. 


\subsubsection{Dureza}

As concentrações de dureza foram obtidas em laboratório por meio de titulação volumétrica, método EDTA. O resultado foi expresso em termos de mg de $\mathrm{CaCO}_{3} / \mathrm{L}$.

\subsubsection{Potencial Hidrogeniônico}

As medidas do potencial hidrogeniônico $(\mathrm{pH})$ das amostras foram feitas por meio de eletrodos seletivos ao íon H (método potenciométrico), utilizando um potenciômetro da marca Micronal modelo B374.

\subsubsection{Condutividade}

Esta variável foi medida em laboratório por meio de um condutivímetro marca Orion, modelo $145 \mathrm{~A}+$. O resultado foi expresso em $\mu \mathrm{S} / \mathrm{cm}$.

\subsubsection{Absorbância a 254nm}

A absorbância das amostras de esgoto não desinfetado e desinfetado foi verificada em comprimento de onda de $254 \mathrm{~nm}$. Suas medidas foram realizadas tanto em amostras brutas como filtradas em membranas de $0,45 \mu \mathrm{m}$ de porosidade, para remover o material particulado. As amostras foram inseridas em cubeta de quartzo com trajetória de $1 \mathrm{~cm}$ e a leitura foi realizada em espectrofotômetro de transmissão "SHIMADZU UV - 160A", no Laboratório de Saneamento do Departamento de Hidráulica e Saneamento da EESC-USP, pelo técnico Paulo Fragiácomo.

\subsubsection{Análises de trihalometanos (THM)}

Neste estudo, foram analisadas quatro espécies de THM: clorofórmio, bromofórmio, bromodiclorometano e dibromoclorometano, que poderiam estar presentes nas amostras de esgoto em um período de $24 \mathrm{~h}$ e $48 \mathrm{~h}$ após os ensaios de desinfecção com o hipoclorito de sódio.

Após os tempos de contato, frascos de vidro âmbar de $100 \mathrm{~mL}$, contendo ácido ascórbico em uma quantidade suficiente para eliminar o residual do oxidante, foram completamente preenchidos com amostras de esgoto desinfetado, devidamente tampados e imediatamente armazenados em geladeira a $4^{\circ} \mathrm{C}$.

As medidas de THMs foram determinadas por cromatografia gasosa, seguindo o método 551 da USEPA (1999a). O cromatógrafo utilizado, da marca Varian 3600CX, era equipado com detector de captura de elétrons (DCE), coluna J\&W-DB-1, 30m x 0,32mm ID e filme de $5 \mu \mathrm{m}$ de espessura. 
As análises foram realizadas no Laboratório de Recursos Hídricos da UNAERP pela técnica responsável Eng. Cristina F. P. Rosa.

\subsubsection{Exames bacteriológicos}

Durante as saídas de campo na ETE-Araraquara, alíquotas de $100 \mathrm{~mL}$ de esgoto não desinfetado foram coletadas em "tio-bags" (contendo tabletes de tiossulfato de sódio) e armazenadas em geladeira a $4^{\circ} \mathrm{C}$ até a realização dos exames bacteriológicos de coliformes totais e Escherichia coli. O mesmo procedimento foi adotado em laboratório com amostras de esgoto desinfetado. O tiossulfato de sódio tem como objetivo desativar eventuais reações de oxidação presentes nas amostras.

Os coliformes totais e E. coli foram examinados pelo método do substrato definido (método Colilert), patenteado pela IDEXX, cujo limite de detecção é de 1 organismo/100mL.

As amostras de esgoto não desinfetado e desinfetado foram diluídas e inoculadas com enzimas Colilert e incubadas por $24 \mathrm{~h}$ a $35,0 \pm 0,5^{\circ} \mathrm{C}$ em bandeja Quanti-Tray, a qual possui 97 poços para análise. Após o período de incubação, foi feita a contagem dos poços que apresentavam coloração amarelada (coliformes totais) e dos poços que apresentavam fluorescência azul ao serem expostas à luz ultravioleta (E. coli). A estimativa de coliformes totais e de E. coli para $100 \mathrm{~mL}$ de amostra foi expressa como número mais provável (NMP/100mL).

\subsection{Ensaios de desinfecção}

Em laboratório, foram realizadas desinfecções no efluente sanitário proveniente da Estação de Tratamento de Esgoto de Araraquara utilizando o ácido peracético (PAA), hipoclorito de sódio e ozônio, em diferentes concentrações e tempos de contato, e radiação ultravioleta, em diferentes intensidades de radiação, a fim de avaliar seu efeito tóxico a diversos organismos-teste.

Logo após cada coleta do efluente final na ETE de Araraquara, uma fração do esgoto foi diretamente utilizada nos ensaios de desinfecção e, em seguida, nos testes de toxicidade. Já outra fração foi armazenada em geladeira a $4^{\circ} \mathrm{C}$ para, a cada 2 dias, executar novos ensaios de desinfecção, a fim de proceder a renovação das amostras utilizadas durante os testes de toxicidade com C. silvestrii, C. xanthus, D. rerio e A. Cepa, cujo sistema de exposição foi semi-estático.

Nas coletas efetuadas em abril e julho de 2004, os ensaios de desinfecção foram realizados apenas com PAA e radiação UV; enquanto que na amostragem de novembro de 2004, foram utilizados nos ensaios de desinfecção o PAA, a radiação UV, o Cloro e o Ozônio. 


\subsubsection{Desinfecção com ácido peracético}

Os ensaios de desinfecção com ácido peracético (PAA) foram realizados em instalação tipo batelada, utilizando-se béqueres de vidro de $2 \mathrm{~L}$ sob agitação.

O produto utilizado para a desinfecção com PAA foi o PROXITANE 1512, o qual é constituído por: ácido peracético (mínimo de 15\%), peróxido de hidrogênio (mínimo de 23\%), ácido acético (máximo de 16\%) e veículo estabilizante (100\%), conforme descrito pelo fornecedor (Thech Desinfecção - SP). Trata-se de uma solução líquida clara, ácida (pH de 2,8) e com odor forte e irritante de vinagre.

A partir do PROXITANE 1512, foi preparada uma solução estoque de 1g/L de PAA, cuja concetração foi confirmada utilizando-se o método colorimétrico DDPD da CHEMetrics de leitura fotométrica.

Para cada ensaio de desinfecção foram utilizados quatro béqueres, dispostos sobre agitadores magnéticos. Em cada béquer foi inserido $1 \mathrm{~L}$ de esgoto homogeneizado e adicionado o volume específico da solução estoque de PAA de forma a obter concentrações de $5 \mathrm{mg} / \mathrm{L}$ e $10 \mathrm{mg} / \mathrm{L}$ do reagente. O tempo de contato foi de 20 e $40 \mathrm{~min}$., após o qual uma alíquota de $25 \mathrm{~mL}$ foi retirada da amostra a fim de verificar a concentração de ácido peracético residual.

A metodologia usada para determinar o ácido peracético residual foi colorimétrica DDPD (em espectrofotômetro Hach DR/2000), desenvolvida e patenteada pela CHEMetrics, na qual utiliza-se o kit Vacu-Vials.

Outra fração da amostra, de $100 \mathrm{~mL}$, teve a reação de oxidação desativada com a adição de tiossulfato de sódio a 3\% na concentração de $0,1 \mathrm{~mL} / 100 \mathrm{~mL}$ de amostra (APHA, 1998), para que, posteriormente, pudesse ser utilizada na análise de coliformes totais e E. coli.

O restante da amostra foi diretamente utilizado nos diversos bioensaios de toxicidade.

\subsubsection{Desinfecção com radiação ultravioleta}

Os ensaios com luz ultravioleta foram realizados em batelada utilizando uma unidade experimental denominada câmara de desinfecção. Essa unidade constitui-se de duas caixas de aço inox retangulares (reatores I e II), um refletor removível de alumínio polido e seis lâmpadas germicidas de baixa pressão de vapor de mercúrio da marca PHILIPS modelo G15-T18, de fabricação holandesa (figura 5.6). As lâmpadas, cujas medidas são 45,0 cm de comprimento por 2,6 cm de diâmetro, são de longa duração e apresentam potência nominal de 15 W. Essas lâmpadas, instaladas na cúpula refletora, são emersas e, portanto, não entram em contato direto com o líquido a ser desinfetado (COLETTI, 2003). 

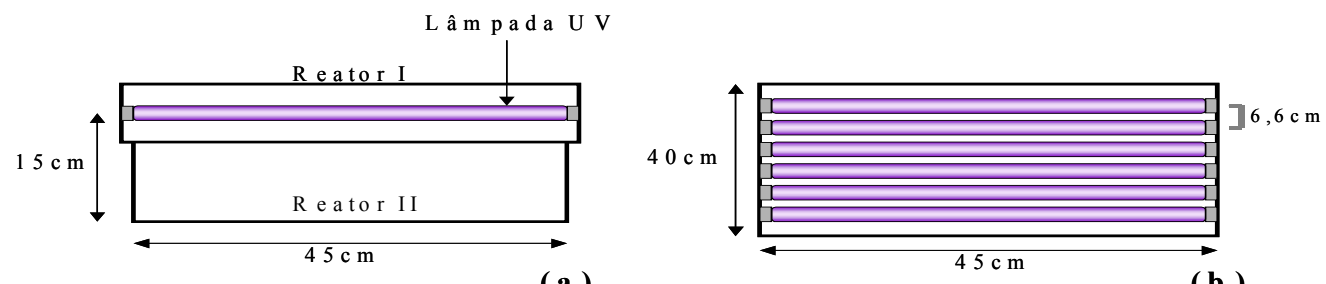

( a )

(b )

Figura 5.6. Representação esquemática da câmara de desinfecção em corte longitudinal (a) e da cúpula refletora em vista interna (b).

Para o aquecimento e estabilização das lâmpadas germicidas, as mesmas foram ligadas 30 minutos antes da exposição do esgoto à irradiação.

A água residuária foi inserida no reator II de forma a atingir uma espessura de lâmina líquida constante de $4 \mathrm{~cm}$, o que equivale a um volume de 7,2L. A câmara de desinfecção foi mantida nivelada para que a lâmina líquida no seu interior recebesse a radiação de forma homogênea.

Com o objetivo de garantir uma irradiação mais uniforme da amostra, o líquido foi mantido homogeneizado através de agitadores magnéticos.

Nos ensaios de desinfecção, 6 lâmpadas germicidas foram ligadas durante dois tempos de irradiação diferentes (30 segundos e 120 segundos). Sendo assim, as amostras de esgoto foram submetidas a uma intensidade de energia radiante constante, porém a doses distintas.

Após cada desinfecção, uma alíquota de $100 \mathrm{~mL}$ do esgoto foi coletada para proceder a análise de coliformes totais e $E$. coli, enquanto que outra fração de mesmo volume foi utilizada para determinar a absorbância da amostra em comprimento de onda de $254 \mathrm{~nm}$. O restante do esgoto desinfetado foi utilizado nos ensaios de toxicidade.

\section{Determinação da intensidade média de radiação ultravioleta incidente}

Para determinar a dose de radiação UV aplicada no efluente, é necessário conhecer a intensidade da radiação no reator e o tempo de irradiação, pois a dose é o produto das duas quantidades. Como os tempos de exposição foram fixados, havia ainda a necessidade de estimar a intensidade média $\left(\mathrm{I}_{0}\right)$ de radiação ultravioleta em $254 \mathrm{~nm}$ incidente na superfície irradiada, expressa em termos de energia incidente por unidade de área $\left(\mathrm{mW} / \mathrm{cm}^{2}\right)$.

Para tanto, utilizou-se o método actinométrico, onde uma substância química reage na presença de luz nos comprimentos de onda de interesse, mudando de cor. É possível calcular a $\mathrm{I}_{0}$ tendo-se o tempo de irradiação e conhecendo a quantidade de reagente consumido ou produto formado em função da quantidade de radiação absorvida (rendimento quântico da substância). 
Neste estudo, a substância actinométrica utilizada foi o ferrioxalato de potássio em solução de $0,006 \mathrm{M}$, que possui rendimento quântico conhecido para o comprimento de onda de $254 \mathrm{~nm}$ (1,26 íon-grama/Einstein) e absorve 99\% da radiação ultravioleta em $1 \mathrm{~cm}$ de trajetória (DANIEL, 2001).

O procedimento para a preparação da solução de ferrioxalato de potássio $0,006 \mathrm{M}$ seguiu a metodologia descrita por Hatchard \& Parker (1956), sendo que os ensaios de actinometria, utilizando-se o Método da Fenantrolina (APHA, 1998), foram realizados em ambiente com pouca iluminação para proporcionar o desenvolvimento de cor da substância actinométrica.

Os ensaios actinométricos para a determinação de $\mathrm{I}_{0}$ no interior do reator foram conduzidos com 6 lâmpadas ligadas, com a lâmina líquida fixada em $1 \mathrm{~cm}$. (volume de 1,8L) e durante o período de 60 segundos.

A concentração de $\mathrm{Fe}^{2+}$ antes e depois da irradiação, determinada a partir de leituras de absorbância realizadas no comprimento de onda de $510 \mathrm{~nm}$ em espectrofotômetro marca “SHIMADZU UV - 2101PC", foi calculada utilizando a curva de calibração de $\mathrm{Fe}^{2+}$ e a equação abaixo:

$$
C_{F e}{ }^{2+}=\frac{C_{\text {medida }} \cdot V_{s}}{V_{a}}
$$

$C_{\mathrm{Fe}^{2+}}$ : concentração de $\mathrm{Fe}^{2+}$ na solução de ferrioxalato de potássio antes e após a irradiação com UV (mg/L)

$\mathrm{C}_{\text {medida }}$ : concentração de $\mathrm{Fe}^{2+}$ obtida pela curva de calibração de determinação espectrofotométrica $(\mathrm{mg} / \mathrm{L})$

$\mathrm{V}_{\mathrm{s}}$ : volume dasolução irradiada $(100 \mathrm{~mL})$

$\mathrm{V}_{\mathrm{a}}$ : volume da alíquota da solução irradiada $(2 \mathrm{~mL})$.

Cabe ressaltar que a curva de calibração de $\mathrm{Fe}^{2+}$ para o espectrofotômetro "SHIMADZU UV - 160A" foi confeccionada a partir da correlação entre volumes definidos de solução de sulfato ferroso $0,1 \mathrm{M}$ e sua correspondente absorbância determinada no equipamento, conforme metodologia estabelecida por Hatchard \& Parker (1956).

A partir da equação (5.1) foi possível calcular a dose de radiação ultravioleta em $254 \mathrm{~nm}$ incidente na superfície irradiada utilizando-se a fórmula:

$$
D=\frac{\left[\mathrm{Fe}^{2+}\right]_{d}-\left[\mathrm{Fe}^{2+}\right]_{a}}{\Phi_{F e}} \cdot 4,719 \times 10^{5}
$$


D: dose de radiação UV em $254 \mathrm{~nm}$ incidente na superfície irradiada (mWs $/ \mathrm{cm}^{3}$ )

$\left[\mathrm{Fe}^{2+}\right]_{\mathrm{d}}$ : concentração molar de $\mathrm{Fe}^{2+}$ depois da irradiação (mol/L)

$\left[\mathrm{Fe}^{2+}\right]_{\mathrm{a}}$ : concentração molar de $\mathrm{Fe}^{2+}$ antes da irradiação (mol/L)

$\phi_{\mathrm{Fe}}$ : rendimento quântico de produção de $\mathrm{Fe}^{2+}$ em 254nm (1,26 íons-grama/Einstein)

$4,719 \times 10^{5}$ : fator de conversão.

Finalmente, a $\mathrm{I}_{0}$ foi estimada pela equação:

$$
I_{0}=\frac{D \cdot L}{t}
$$

$\mathrm{I}_{0}$ : intensidade média de radiação UV incidente na superfície irradiada $\left(\mathrm{mW} / \mathrm{cm}^{2}\right)$

$\mathrm{L}$ : espessura da lâmina líquida $(\mathrm{cm})$

t: tempo de exposição (s)

\section{Dosagem de radiação UV}

Considerando que a intensidade de energia radiante diminui à medida que aumenta a espessura da lâmina líquida e que parte da energia emitida pela fonte de radiação é absorvida por substâncias presentes na amostra (material dissolvido ou em suspensão), após determinada a $\mathrm{I}_{0}$, há a necessidade de calcular a intensidade média de radiação na lâmina líquida durante os ensaios de desinfecção. Esse cálculo pode ser feito pela integração da Lei de Beer-Lambert:

$$
I_{m}=\frac{I_{0}}{L} \int_{0}^{L} e^{-a x} d x
$$

Im : intensidade média de radiação UV na lâmina líquida de espessura $\mathrm{L}\left(\mathrm{mW} / \mathrm{cm}^{2}\right)$

$\mathrm{I}_{0}$ : intensidade média de radiação UV incidente na superfície irradiada $\left(\mathrm{mW} / \mathrm{cm}^{2}\right)$

$\alpha$ : coeficiente de extinção ou de absorção $\left(\mathrm{cm}^{-1}\right)$

O coeficiente de extinção ou de absorção depende da qualidade da amostra e deve ser calculado a partir da absorbância do efluente desinfetado em comprimento de onda de $254 \mathrm{~nm}$ :

$$
A=-\log T
$$
A : absorbância
$\mathrm{T}:$ transmitância 


$$
A=-\log e^{-a x}
$$

Como a absorbância é medida em espectrofotômetro em cubeta de quartzo de $1 \mathrm{~cm}$ de trajetória, $\operatorname{logo}, \mathrm{x}=1$. Então:

$$
a=2,303 A
$$

Obtendo-se o valor da intensidade média de radiação UV na lâmina líquida, pode-se calcular a dose de radiação recebida pela amostra de efluente, isto é, a energia total que efetivamente estava disponível para a inativação dos microorganismos, que é dada por:

$$
D_{r}=I_{m} \cdot t
$$

$\mathrm{D}_{\mathrm{r}}$ : dose recebida de radiação ultravioleta $\left(\mathrm{Wh} / \mathrm{m}^{3}\right)$

$\mathrm{I}_{\mathrm{m}}$ : intensidade média de radiação UV na lâmina líquida $\left(\mathrm{Wh} / \mathrm{m}^{3}\right)$

t: tempo de exposição (s)

\subsubsection{Desinfecção com cloro}

Os ensaios de desinfecção com cloro foram realizados em instalação tipo batelada, utilizando-se béqueres de vidro de $2 \mathrm{~L}$ sob agitação. A substância empregada como desinfetante foi o hipoclorito de sódio $(\mathrm{NaOCl})$ a $12 \%$, que é uma solução líquida clara, levemente amarelada, alcalina e muito corrosiva.

Esses ensaios foram conduzidos de forma análoga aos ensaios de desinfecção com PAA. As concentrações de 2,5mg/L e 7,0mg/L de cloro livre utilizadas para a desinfecção do esgoto foram preparadas a partir de uma solução estoque de $1 \mathrm{~g} / \mathrm{L}$ de hipoclorito de sódio. O tempo de contato foi de 20 e 40 min., após o qual a amostra foi dividida em 4 lotes:

1. O primeiro lote, constituído por um volume de $25 \mathrm{~mL}$, foi utilizado para verificar a concentração de cloro residual livre e total na amostra. O cloro residual foi mensurado através do método colorimétrico DPD (em espectrofotômetro Hach DR/2000), proposto pela CHEMetrics, no qual utiliza-se o kit Vacu-Vials e tem como referência APHA (1998).

2. O segundo lote, constituído por uma alíquota de $100 \mathrm{~mL}$ da amostra, foi utilizado para a análise de coliformes totais e E. coli após a adição de tiossulfato de sódio a 3\% na concentração de 0,1mL/100mL de amostra (APHA, 1998).

3. O terceiro lote, constituído por um volume de $100 \mathrm{~mL}$, foi armazenado e posteriormente utilizado para a determinação de trihalometanos (THMs), conforme descrito no item 5.4.16. 
4. O último lote, que continha o restante da amostra, foi diretamente utilizado nos diversos bioensaios de toxicidade, sem prévia descloração.

\subsubsection{Desinfecção com ozônio}

Os ensaios de desinfecção com ozônio foram realizados em batelada na unidade piloto instalada no Laboratório de Tratamento de Resíduos Orgânicos (LTR), que pertence ao Departamento de Hidráulica e Saneamento da EESC/USP de São Carlos.

\section{Unidade piloto}

A unidade piloto consiste de um cilindro de oxigênio (1), dois filtros de ar (2), uma válvula reguladora de pressão (3), um rotâmetro (4), uma câmara de refrigeração (5), o gerador de ozônio (6) e a câmara de ozonização (7) com o frasco lavador (8). A câmara de ozonização e o frasco lavador são sustentados por uma grade metálica (figura 5.7).

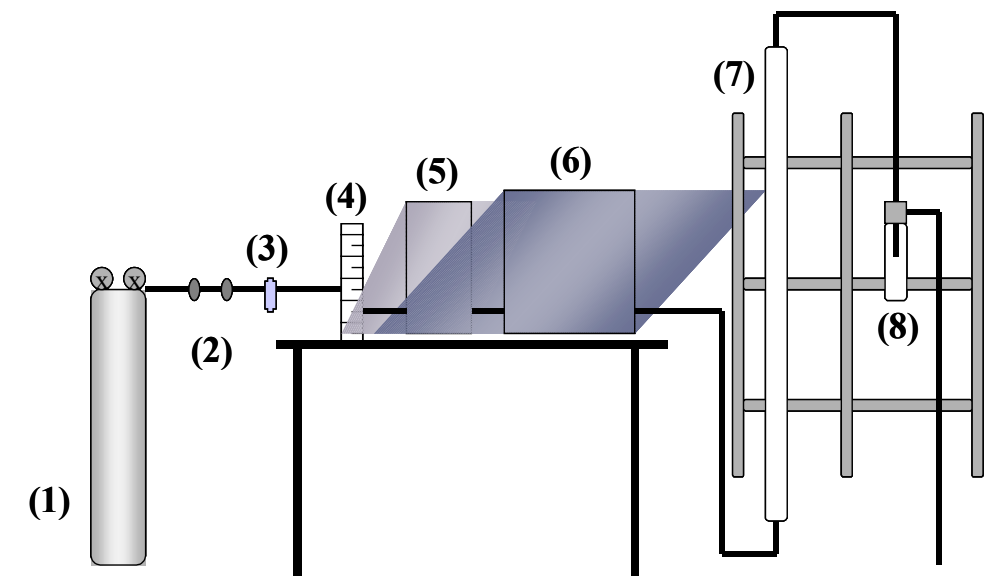

Figura 5.7. Representação esquemática da unidade piloto utilizada nos ensaios de desinfecção com ozônio.

$$
\text { Adaptado de Bilotta (2000). }
$$

(1) O cilindro de oxigênio puro (98\%), que possui capacidade de $10 \mathrm{~m}^{3}$, alimenta o gerador de ozônio.

(2) Os filtros Schulz, fixados próximos à saída de ar do compressor, são responsáveis pela retenção de partículas superiores a $0,3 \mu \mathrm{m}$ (filtro particulado) e pela redução da umidade de ar (filtro coalescente).

(3) A válvula reguladora de pressão tem a função de controlar a pressão de entrada de oxigênio no gerador de ozônio em até 0,5 bar, pois acima deste valor, as paredes internas das câmaras responsáveis pelas descargas elétricas podem sofrer fissuras. 
(4) O rotâmetro (modelo $O M E L$ ) controla a vazão de entrada de oxigênio no equipamento, o que é fundamental, pois a produção de ozônio é diretamente proporcional à vazão de gás que atinge o ozonizador. O rotâmetro é composto por uma coluna de vidro graduada e um marcador esférico metálico que flutua na escala de 0 a 400L/h em função da vazão ajustada.

O sistema de refrigeração (modelo Belliere), instalado na saída do rotâmetro, tem o objetivo de evitar o superaquecimento do gerador de ozônio, o qual favorece a decomposição do $\mathrm{O}_{3}$ em $\mathrm{O}_{2}$. Além disso, a umidade do ar na entrada do ozonizador deve ser mínima. Sendo assim, o sistema possui uma serpentina de cobre imersa em água mantida à temperatura de cerca de $4^{\circ} \mathrm{C}$. Quando o ar circula pela serpentina, a baixa temperatura do meio condensa as gotículas de água que vão acabar se acumulando em um recipiente externo (BILOTTA, 2000).

(6) O gerador de ozônio utilizado neste estudo era da marca Qualid'or modelo laboratorial. Neste equipamento, o oxigênio é convertido em ozônio através de uma descarga corona, isto é, na passagem de oxigênio entre dois eletrodos, aos quais é aplicada uma alta tensão que varia entre 8 e $20 \mathrm{kV}$. A tabela 5.3 relaciona as características técnicas do ozonizador (DIAS, 2001).

O gerador de ozônio foi mantido em funcionamento por aproximadamente 15 minutos antes da realização dos ensaios, para garantir o aquecimento e estabilização do equipamento.

Tabela 5.3. Características técnicas do ozonizador modelo laboratorial.

\begin{tabular}{|c|c|}
\hline \multicolumn{2}{|c|}{ Especificações técnicas } \\
\hline Pressão máxima & $0,5 \mathrm{kgf} / \mathrm{cm}^{2}$ \\
\hline Peso & $40 \mathrm{~kg}$ \\
\hline Dimensão & $50 \times 50 \times 30 \mathrm{~cm}$ \\
\hline Tensão & $220 \mathrm{~V}$ \\
\hline Vazão máxima & $12 \mathrm{~L} / \mathrm{min}$ \\
\hline Amperímetro & $0-2 \mathrm{~A}(\mathrm{média:} 1,2 \mathrm{~A})$ \\
\hline Manômetro & $0-2 \mathrm{kgf} / \mathrm{cm}^{2}$ \\
\hline Intensidade & Mínima, média e máxima \\
\hline Capacidade & $8 \mathrm{~g} \mathrm{O} \mathrm{O}_{3} / \mathrm{h}$ \\
\hline
\end{tabular}

(7) A câmara de ozonização (ou câmara de contato), construída em acrílico com $2 \mathrm{~m}$ de altura e $52 \mathrm{~mm}$ de diâmetro interno, é o local onde ocorre a transferência do gás (ozônio) para o líquido (efuente) e, portanto, é onde acontece a desinfecção propriamente dita. A configuração da câmara de ozonização dessa unidade piloto é a coluna líquida com injeção de gás contra-corrente (fluxo de gás ascendente e fluxo líquido descendente) e dispersão através de bolhas (figura 5.8).

O ensaio de desinfecção com ozônio foi feito através da transferência do esgoto para o interior da câmara de ozonização, por meio de um funil (a). Preenchida a coluna, o registro da esfera foi fechado (b), o gerador de ozônio ligado e o registro da agulha aberto (c), dando início à ozonização. Ao término do tempo de contato, o ozonizador foi desligado, os registros e esfera (b) e 
(d) abertos e o efluente desinfetado foi retirado para análises posteriores e para a realização dos bioensaios. A fração de ozônio gasoso excedente (off-gas) na câmara de contato foi capturado no frasco lavador (e).

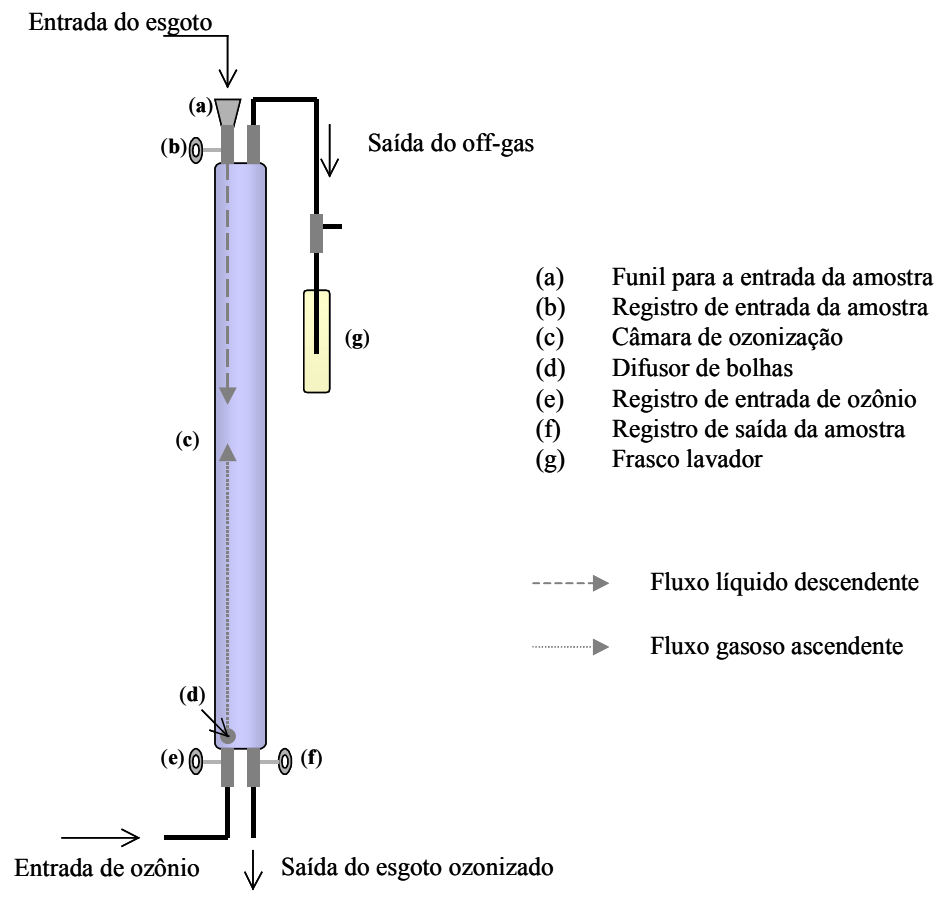

Figura 5.8. Representação esquemática da câmara de ozonização ou de contato.

Adaptado de Monaco (2006).

(8) O frasco lavador, com capacidade de $1 \mathrm{~L}$, foi preenchido, antes da ozonização, com $500 \mathrm{~mL}$ de uma solução de iodeto de potássio (KI) a 2\% para avaliar a concentração de excesso de ozônio (off-gas) na coluna a partir do método iodométrico (titulometria), como descrito em APHA (1998).

\section{Determinação da produção de ozônio}

A capacidade de produção de ozônio do gerador Qualid'or foi determinada a partir de uma curva de calibração calculada por SARTORI (2004), utilizando o método iodométrico (titulometria) (APHA, 1998).

A produção foi quantificada variando-se a vazão de gás que percorria a câmara de contato contendo KI a $2 \%$, empregando titulometria com tiossulfato de sódio $0,025 \mathrm{~N}$. Para a construção da curva, foram adotados os seguintes valores de vazão de oxigênio: $5 ; 10 ; 20 ; 30 ; 60 ; 100 ; 150 ; 200$ e $300 \mathrm{~L} / \mathrm{h}$, sendo o tempo de contato fixado em 10 minutos.

A produção de ozônio foi calculada pela equação: 


$$
P=\frac{N \times 14,4 \times(V t-V b) \times V c}{V \times t}
$$

P: Produção de $\mathrm{O}_{3}$ ou do off-gas $\left(\mathrm{gO}_{3} / \mathrm{h}\right)$

$\mathrm{N}$ : Normalidade do titulante $\mathrm{Na}_{2} \mathrm{~S}_{2} \mathrm{O}_{3}(0,025 \mathrm{~N})$

$\mathrm{V}_{\mathrm{t}}$ : Volume da solução de $\mathrm{Na}_{2} \mathrm{~S}_{2} \mathrm{O}_{3}$ consumido na amostra $(\mathrm{mL})$

$\mathrm{V}_{\mathrm{b}}$ : Volume da solução de $\mathrm{Na}_{2} \mathrm{~S}_{2} \mathrm{O}_{3}$ consumido no branco $(\mathrm{mL})$

$\mathrm{V}_{\mathrm{c}}$ : Volume da solução de KI na câmara de ozonização (L)

V: Volume coletado da amostra ozonizada $(\mathrm{mL})$

t: Tempo de contato

14,4: Fator de conversão de unidades

Na figura 5.9 pode-se observar a curva de calibração confecionada para o gerador de ozônio utilizado neste estudo.

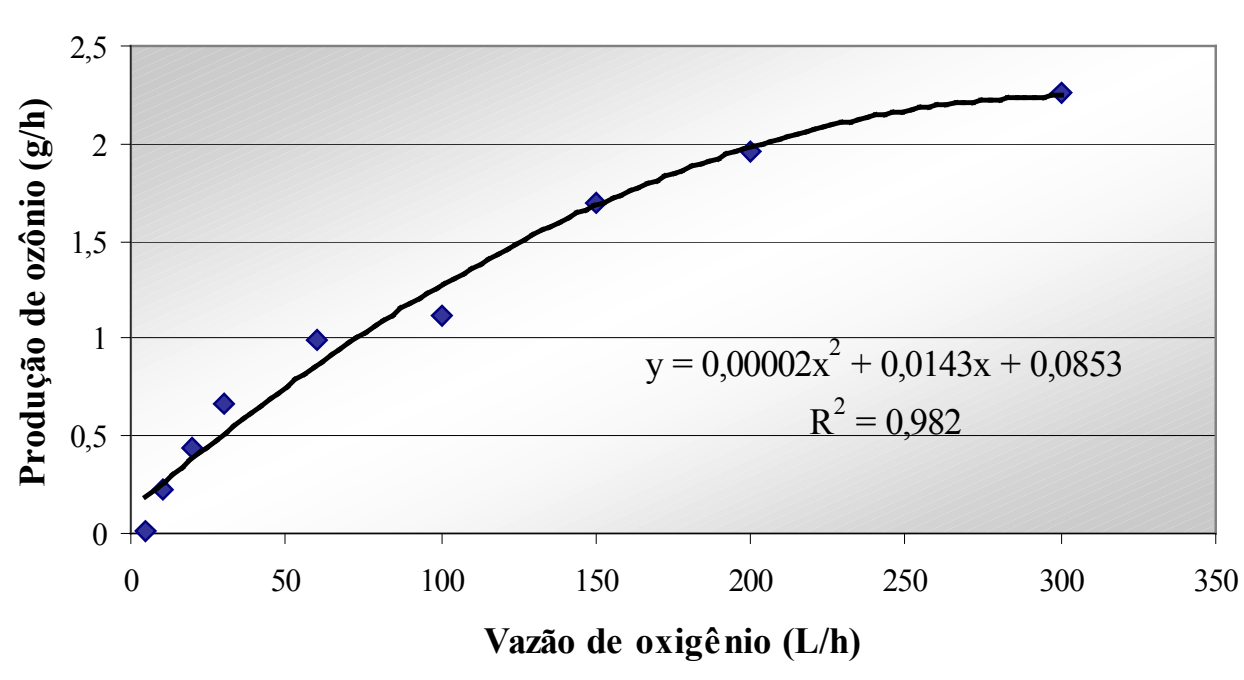

Figura 5.9. Produção de ozônio do equipamento Qualid'or em relação à vazão de oxigênio (calculada por SARTORI, 2004).

Com base na equação da curva de calibração acima, foi possível calcular as vazões de oxigênio que foram utilizadas neste estudo para alcançar as dosagens e tempo de contato definidos.

Para relacionar dosagem e produção de ozônio, utilizou-se a equação (5.10):

$$
D=\frac{P \times t \times 100}{6 \times V_{l}}
$$


$\mathrm{D}$ : dosagem de ozônio $(\mathrm{mg} / \mathrm{L})$

$\mathrm{P}$ : produção de ozônio $(\mathrm{g} / \mathrm{h})$

$\mathrm{t}$ : tempo de contato (minutos)

$\mathrm{V}_{1}$ : volume do efluente na coluna $(\mathrm{mL})$

\section{Ensaios de ozonização}

Para os ensaios de desinfecção, 1,5L de esgoto foram inseridos na câmara de ozonização, sendo utilizadas as vazões de oxigênio de $18 \mathrm{~L} / \mathrm{h}$ e $30 \mathrm{~L} / \mathrm{h}$ em um tempo de contato de 5 minutos.

Ao término dos ensaios, as amostras retiradas da câmara de contato foram encaminhadas ao CRHEA para a realização dos bioensaios.

Cumpre observar que um volume de $25 \mathrm{~mL}$ de cada amostra foi utilizado para verificar a concentração de ozônio residual ainda presente no esgoto desinfetado, através do método colorimétrico Índigo (em espectrofotômetro Hach DR/2000), proposto pela CHEMetrics, no qual utiliza-se o kit Vacu-Vials.

Outra fração da amostra, de $100 \mathrm{~mL}$, que posteriormente foi utilizada para a análise de coliformes totais e $E$. coli, teve a reação de oxidação desativada com a adição de tiossulfato de sódio a 3\% na concentração de $0,1 \mathrm{~mL} / 100 \mathrm{~mL}$ de amostra (APHA, op. cit.).

Além disso, foi recolhida uma alíquota de $200 \mathrm{~mL}$ da solução de KI do frasco lavador para determinar a concentração de ozônio gasoso que não foi absorvido pelo esgoto durante o processo de desinfecção (off-gas), utilizando-se, para tanto, as equações 5.9 e 5.10 .

A dose de ozônio efetivamente consumida pela amostra foi calculada pela expressão (5.11):

$$
\text { Dose efetiva }=\text { Dose aplicada }- \text { (ozônio residual + “off-gas”) }
$$

\subsubsection{Eficiência de desinfecção}

A eficiência de cada sistema de desinfecção, avaliada pela redução do número de coliformes totais e E. coli, foi calculada pela fórmula:

$$
E=\frac{C o-C e}{C o} \cdot 100
$$

$\mathrm{E}=$ eficiência de desinfecção (\%)

$\mathrm{C}_{\mathrm{o}}=$ concentração de coliformes totais ou $E$. coli antes da desinfecção

$\mathrm{C}_{\mathrm{e}}=$ concentração de coliformes totais ou $E$. coli após a desinfecção 


\subsection{Bioensaios}

Neste estudo, foram realizados bioensaios com diluição seriada de esgoto bruto e efluente tratado, bioensaios com amostras de esgoto desinfetado e testes de toxicidade com agentes desinfetantes.

No caso da $1^{\text {a }}$ coleta, realizada em setembro de 2003, foram conduzidos bioensaios com diluições seriadas, isto é, foram testadas amostras integrais (concentração de 100\%) e diluídas (concentrações de 75\%, 50\% e 25\%) de esgoto bruto e tratado, utilizando Daphnia similis, Ceriodaphnia silvestrii, Danio rerio e Chironomus xanthus como organismos-teste. Os resultados desses primeiros ensaios foram expressos em termos de Concentração de Efeito Não Observado (CENO), isto é, a maior concentração da amostra que não causou efeito deletério estatísticamente significativo na sobrevivência e reprodução dos organismos-teste.

Nas demais coletas, efetuadas em abril, julho e novembro de 2004, os bioensaios foram realizados com amostras integrais de esgoto tratado antes e após cada desinfecção, utilizando Daphnia similis, Ceriodaphnia silvestrii, Danio rerio, Chironomus xanthus e Allium cepa como organismos-teste. Nesses casos, os resultados dos bioensaios foram expressos em termos qualitativos, isto é, como “tóxicos" ou "não tóxicos", confirmados por análises estatísticas específicas.

Ressalta-se que os testes de toxicidade acima referidos foram iniciados no mesmo dia de coleta dos esgotos, seguindo orientação de Gherardi-Goldstein et al. (1990), que afirmam que as amostras de efluentes devem ser utilizadas em bioensaios até, no máximo, 24h após sua coleta.

Para os testes de toxicidade com C. silvestrii, C. xanthus, D. rerio e A. cepa, cujo sistema de exposição é semi-estático, houve necessidade de preservar as amostras de esgoto em geladeira a $4^{\circ} \mathrm{C}$ para proceder a renovação da substância-teste (no caso, o efluente) ao longo dos ensaios.

Além dos bioensaios com amostras de esgoto, também foram realizados testes de toxicidade com hipoclorito de sódio, ácido peracético e radiação ultravioleta, isoladamente, a fim de avaliar a sensibilidade dos organismos-teste a diferentes concentrações (ou doses, no caso da radiação ultravioleta) dos referidos agentes de desinfecção. Não houve possibilidade de determinar a sensibilidade dos organismos-teste ao ozônio devido a dificuldades em estabelecer baixas dosagens desse gás na água de cultivo que seria utilizada nos testes. Cumpre observar que o equipamento da unidade piloto que controla a entrada de ar no gerador de ozônio, o rotâmetro, possui uma escala muito ampla (de 0 a $400 \mathrm{~L} / \mathrm{h}$ ).

Cabe ainda ressaltar que a sensibilidade dos organismos-teste ao longo de diferentes gerações foi avaliada por meio de ensaios com substâncias de referência definidas, com o objetivo de averiguar a qualidade e homogeneidade das culturas e possibilitar sua utilização nos bioensaios realizados no presente estudo. 
As metodologias dos bioensaios para cada organismo-teste utilizado neste trabalho, bem como a biologia e ecologia das espécies, são descritas a seguir.

\subsubsection{Daphnia similis Claus, 1876 (Crustacea: Cladocera)}

A Daphnia similis é um microcrustáceo zooplanctônico de água doce que mede até $3,5 \mathrm{~mm}$ de comprimento e apresenta forma arredondada (figura 5.10). As espécies da família Daphniidae, popularmente conhecidas como pulgas d'água, são abundantes no meio aquático e exercem funções importantes na cadeia alimentar, já que são filtradores (nutrem-se de algas, detritos e bactérias em suspensão) e servem de alimento para consumidores secundários.

Deve-se ressaltar que os cladóceros, incluindo a $D$. similis, estão entre os organismos mais utilizados em bioensaios no mundo, devido a sua facilidade de cultivo em laboratório, sensibilidade constante aos agentes tóxicos (em função de sua reprodução partenogenética, que propicia homogeneidade de seu material genético), curto ciclo de vida e outras características intrínsecas do grupo (USEPA, 2002). Testes com esses organismos foram os primeiros a serem estabelecidos e exigidos no Brasil (na década de 1980), sendo esse grupo recomendado para representar os invertebrados aquáticos em estudos ecotoxicológicos (IBAMA, 1990).

Apesar da D. similis ser um organismo alóctone (encontrado em diversos ecossistemas da Europa e dos Estados Unidos) e, portanto, não apresentar relevância ecológica para as águas interiores do Brasil, sua utilização neste trabalho é bastante útil uma vez que, por apresentar metodologia de teste padronizada, seus resultados podem ser comparados com qualquer outro estudo realizado com este organismo por outros pesquisadores, aumentando o aproveitamento de dados publicados. Ademais, essa espécie tem tido sua biologia amplamente estudada (HERBERT, 1978) e tem sido muito utilizada para avaliar a toxicidade de efluentes líquidos.

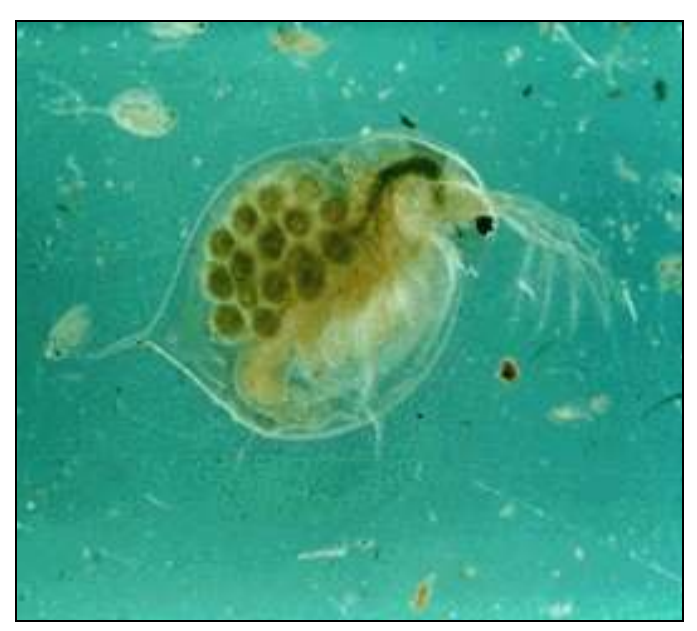

Figura 5.10. Daphnia sp. 


\subsubsection{Manutenção das culturas de $D$. similis}

As culturas de D. similis foram mantidas no Laboratório de Ecotoxicologia e Ecofisiologia de Organismos Aquáticos do NEEA/CRHEA/EESC-USP, seguindo metodologia recomendada pela CETESB (1992).

Lotes de cerca de 50 organismos adultos foram mantidos em cristalizadores de vidro de $2 \mathrm{~L}$, contendo água reconstituída (oriunda de poço artesiano) filtrada e ajustada para pH entre 7,0 e 7,6 e dureza de 40 a $48 \mathrm{mgCaCO}_{3} / \mathrm{L}$. Os cristalizadores permaneceram em câmara incubadora de demanda bioquímica de oxigênio (DBO), com temperatura de $23 \pm 2{ }^{\circ} \mathrm{C}$ e fotoperíodo de $16 \mathrm{~h}$ luz.

O alimento, fornecido diariamente, constituiu-se de suspensão algácea de Pseudokirneriela subcapitata na concentração de 1 × $10^{6}$ células de alga por organismo, e de uma solução composta por ração microfloculada de alevinos de peixe e fermento tipo Fleishman.

\subsubsection{Bioensaios de toxicidade aguda com amostras de esgoto utilizando $D$. similis como organismo-teste}

Os bioensaios com $D$. similis seguiram metodologia padronizada pela CETESB, norma L5.018 (1992). Os testes são agudos, estáticos e com 48 horas de duração, sendo que o efeito observado é a imobilidade. Os organismos utilizados no experimento devem apresentar idade entre 6 a 24 horas e devem ser obtidos por partenogênese a partir de fêmeas com idade entre 7 e 28 dias. Para cada um dos tratamentos e para o controle, são preparadas 4 réplicas contendo 5 organismos em $10 \mathrm{~mL}$ de amostra, sendo o controle constituído pela mesma água utilizada no cultivo de $D$. similis (água reconstituída). Durante o teste não é fornecida alimentação, aeração nem iluminação. A temperatura pode variar entre $22 \pm 2^{\circ} \mathrm{C}$ ao longo do bioensaio.

No início e final dos testes foram verificados o $\mathrm{pH}$, oxigênio dissolvido, dureza e condutividade das amostras e do controle.

\subsubsection{Ceriodaphnia silvestrii Daday, 1902 (Crustacea: Cladocera)}

C. silvestrii também é um microcrustáceo zooplanctônico de água doce pertencente à família Daphniidae. Este organismo mede de 0,8 a $0,9 \mathrm{~mm}$ de comprimento, possui corpo ovalado com acentuado sinus cervical e com 9 a 12 espinhos anais (figura 5.11) (ABNT, 2005).

Como os microcrustáceos em geral, C. silvestrii ocupa lugar de destaque na cadeia trófica, pois atua como consumidor primário, se alimentando por filtração de material orgânico particulado, e é predado por consumidores secundários, como outros invertebrados e peixes. Ao contrário da $D$. similis, a espécie $C$. silvestrii é amplamente encontrada em águas continentais brasileiras e 
argentinas, principalmente em ambientes lênticos. Logo, a utilização dessa espécie como organismo-teste apresenta alta relevância ecológica neste estudo.

Cumpre observar que à época do desenvolvimento experimental deste trabalho, $C$. silvestrii ainda não apresentava metodologia de testes padronizada, porém, atualmente a norma técnica 13373 da ABNT (2005) já estabelece o protocolo de ensaios de toxicidade padronizado para essa espécie.

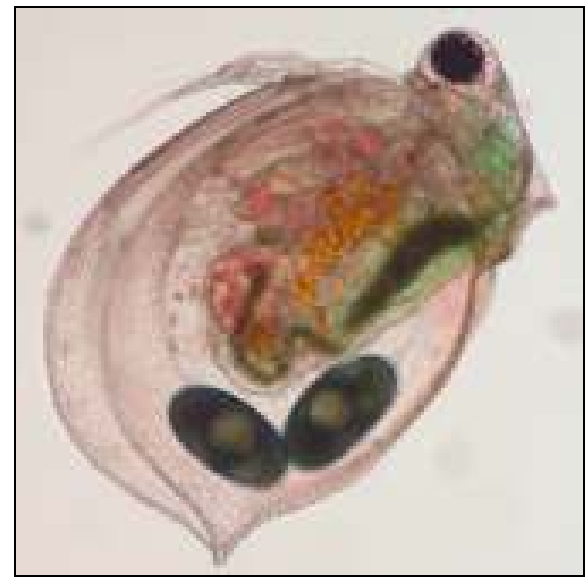

Figura 5.11. Ceriodaphnia silvestrii.

\subsubsection{Manutenção das culturas de $C$. silvestrii}

Os organismos cultivados no Laboratório de Ecotoxicologia e Ecofisiologia de Organismos Aquáticos do NEEA/CRHEA/EESC-USP foram originalmente obtidos nos tanques de plâncton da Reserva Experimental da Universidade Federal de São Carlos (UFSCar).

As culturas de $C$. silvestrii foram mantidas em cristalizadores de vidro de 1L com água reconstituída (oriunda de poço artesiano) filtrada e ajustada para $\mathrm{pH}$ entre 7,0 e 7,6 e dureza de 40 a $48 \mathrm{mgCaCO}_{3} / \mathrm{L}$. Cada cristalizador, contendo cerca de 50 fêmeas adultas, permaneceu em câmara incubadora de demanda bioquímica de oxigênio (DBO), com temperatura de $23 \pm 2{ }^{\circ} \mathrm{C}$ e fotoperíodo de $16 \mathrm{~h}$ luz.

O alimento, fornecido diariamente, constituiu-se de suspensão algácea de Pseudokirneriela subcapitata, na concentração de $1 \times 10^{5}$ células de alga por organismo, e de uma solução composta por ração microfloculada de alevinos de peixe e fermento tipo Fleishman.

A metodologia de cultivo acima descrita foi adaptada de CETESB (1992). 


\subsubsection{Bioensaios de toxicidade crônica com amostras de esgoto utilizando $C$. silvestrii como organismo-teste}

Os bioensaios com $C$. silvestrii foram baseados na metodologia de testes para Ceriodaphnia dubia padronizada pela CETESB, norma L5.022 (1992), já que, à época do desenvolvimento experimental deste trabalho, $C$. silvestrii ainda não apresentava protocolo de ensaios de toxicidade padronizada.

Os ensaios são crônicos, com renovação de água a cada 48 horas e com 7 dias de duração, sendo que o efeito observado é a reprodução. Os organismos utilizados no experimento devem apresentar idade entre 4 e 8 horas e devem ser obtidos por partenogênese a partir de fêmeas com idade entre 7 e 21 dias. Para cada um dos tratamentos e para o controle, são preparadas 10 réplicas contendo 1 organismo em $15 \mathrm{~mL}$ de amostra. A água do controle utilizada no teste é a mesma do cultivo (água reconstituída). Durante o teste é fornecida alimentação diariamente, porém não é adicionada aeração e o fotoperíodo é de 16 horas luz. A temperatura pode variar entre $23 \pm 2^{\circ} \mathrm{C}$ ao longo do teste.

Os bioensaios com C. silvestrii podem expressar tanto efeito agudo (imobilidade) como efeito crônico (reprodução); por isso, a cada renovação de água, foi observado o número de neonatos em cada béquer e a mobilidade dos adultos, sendo realizadas medidas de $\mathrm{pH}$, oxigênio dissolvido, condutividade e dureza da água.

\subsubsection{Chironomus xanthus Rempel, 1931 (Insecta: Diptera)}

Chironomus xanthus (figura 5.12) é um inseto neotropical pertencente à família Chironomidae que possui sinonímia com Chironomus domizzi (PAGGI, 1977 apud FONSECA, 1997) e Chironomus sancticaroli (STRIXINO; STRIXINO, 1982). Seu ciclo de vida pode ser dividido em quatro estágios distintos: ovo, larva, pupa e adulto, os quais se alternam entre a fase aquática (estágio imaturo) e a fase aérea (adulto). Durante a fase aquática, as larvas são bentônicas e vivem em tubos, formados por seda e lodo, que ficam enterrados a poucos centímetros de profundidade do sedimento.

Os Chironomidae são representados por um grande número de espécies, as quais apresentam alta abundância. São cosmopolitas e extremamente adaptáveis a todos os tipos de ambientes, possuindo um amplo espectro quanto aos requisitos ambientais (LINDEGAARD, 1995). Algumas espécies possuem hemoglobina, o que as torna capazes de tolerar baixas concentrações de oxigênio.

Cumpre ressaltar que diversas espécies de quironomídeos, tais como $C$. tentans e $C$. riparius, têm sido utilizadas de forma eficiente como organismos-teste na avaliação da toxicidade de sedimentos em diferentes países (ARAÚJO et al., 2006). 


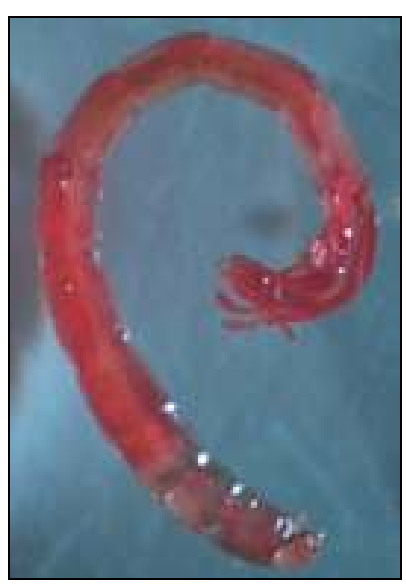

Figura 5.12. Larva de Chironomus xanthus.

Chironomus xanthus é uma espécie autóctone que ocorre no estado de São Paulo e, portanto, apresenta relevância ecológica regional, constituindo frequentemente a proporção mais significativa da biomassa da comunidade bentônica, possuindo papel significativo na reciclagem e fixação de nutrientes no sedimento e sendo importante na dieta de aves e peixes (BAUDIN; NUCHO, 1992).

Esta espécie, nas últimas décadas, vem sendo utilizada em diversos estudos ecotoxicológicos com sedimentos no Brasil (ALMEIDA, 2002; ALMEIDA 2007; DORNFELD, 2002; FONSECA, 1997; PAMPLIN, 1999) devido a sua fácil manutenção em laboratório, curto ciclo de vida e a alta fecundidade.

A utilização de C. xanthus neste estudo tem por finalidade avaliar se o efluente, antes e após a desinfecção, pode causar efeito deletério a organismos bentônicos através da transferência de substâncias potencialmente tóxicas da coluna d'água para o sedimento.

\subsubsection{Manutenção das culturas de $C$. xanthus}

As culturas de C. xanthus foram mantidas no Laboratório de Ecotoxicologia e Ecofisiologia de Organismos Aquáticos do NEEA/CRHEA/EESC-USP, seguindo metodologia adaptada por Fonseca (1997).

Os organismos foram mantidos em bandejas de plástico retangulares contendo cerca de $200 \mathrm{~g}$ de areia (isenta de matéria orgânica) e $6 \mathrm{~L}$ de água reconstituída (água natural oriunda de poço artesiano isento de contaminantes) filtrada e ajustada para $\mathrm{pH}$ entre 7,0 e 7,6 e dureza de 40 a 48 $\mathrm{mgCaCO}_{3} / \mathrm{L}$. Cada bandeja continha aproximadamente 200 a 400 larvas dos insetos, os quais foram mantidos sob aeração branda e constante, com um fotoperíodo de $12 \mathrm{~h}$ luz e com a temperatura variando entre 22 e $26^{\circ} \mathrm{C}$. 
Cada bandeja foi coberta por uma gaiola de tela de náilon para reter os adultos emergentes, sendo que a alimentação, constituída por uma solução de ração de peixe em flocos, foi fornecida na concentração de 5,0g/L a cada $48 \mathrm{~h}$.

\subsubsection{Bioensaios de toxicidade crônica com amostras de esgoto utilizando $C$. xanthus como organismo-teste}

Os bioensaios com C. xanthus são baseados no procedimento adaptado por Fonseca (1997). Os ensaios são crônicos, com renovação de 1/3 do volume de amostra a cada 48 horas e com 7 dias de duração, sendo que o efeito observado é a mortalidade.

Nos testes crônicos com este organismo, se utiliza uma proporção de 1:4 sedimento/água (amostra), sendo que o sedimento utilizado no teste, que é o mesmo do cultivo, é incinerado em mufla a $550^{\circ} \mathrm{C}$ por 2 horas, para a retirada da matéria orgânica. Sendo assim, para cada tratamento e para o controle, são preparadas 5 réplicas contendo $15 \mathrm{~g}$ de sedimento e $60 \mathrm{~mL}$ de amostra. Em cada réplica são inseridos 2 organismos que devem se encontrar no $2^{\circ}$ ínstar larval. A água do controle utilizada no teste é a mesma do cultivo. Durante o teste, o fotoperíodo é de $12 \mathrm{~h}$ luz e a temperatura pode variar entre 22 e $26^{\circ} \mathrm{C}$. Não é fornecida aeração e a alimentação é adicionada a cada 48 horas.

No início e final dos testes foram realizadas medidas de $\mathrm{pH}$, oxigênio dissolvido, condutividade e dureza da água.

\subsubsection{Danio rerio Hamilton-Buchana, 1822 (Cypriniformes: Cyprinidae)}

O peixe ornamental Danio rerio é um teleósteo dulcícola de pequeno porte, com comprimento médio de 4,0 a 5,0 cm. É popularmente conhecido como paulistinha ou peixe-zebra, uma vez que apresenta listras horizontais na lateral do corpo (figura 5.13). Trata-se de um peixe tropical, ovíparo e omnívoro, que atua como consumidor secundário na cadeia trófica aquática. Essa

espécie de peixe é originária da Índia e do Paquistão e foi introduzida em diversos países do mundo (ABNT, 2003).

O peixe-zebra apresenta inúmeras características vantajosas que o tornaram um modelo vertebrado importante para estudos ecotoxicológicos: é um organismo relativamente pequeno e que requer pouco espaço para sua manutenção em laboratório; conseqüentemente, combina a relevância de ser um vertebrado com a escala de estudo de um organismo invertebrado. Ademais, é de fácil obtenção e manipulação, apresenta baixo custo, possui reprodução rápida e capacidade de absorver prontamente compostos adicionados à água. 


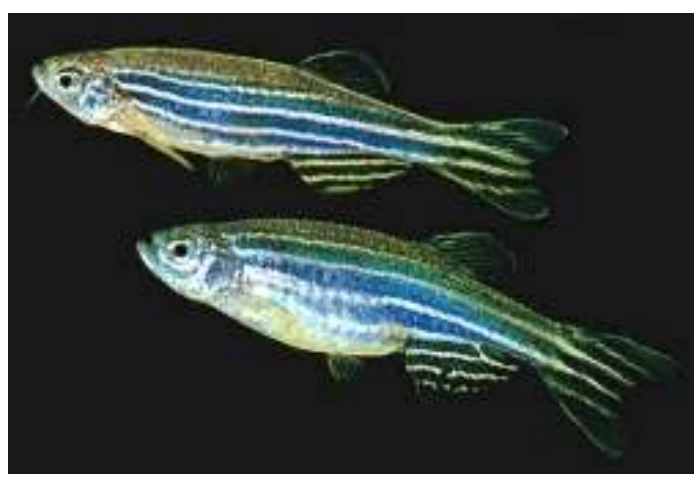

Figura 5.13. Danio rerio.

Fonte: http://www.forumlabo.com/2002/actus/cnrs/pics

Esse peixe foi um dos primeiros organismos a ser utilizado em testes de toxicidade pela CETESB, em 1977, e é amplamente utilizado em estudos ecotoxicológicos no mundo todo. Por todos os fatores acima citados e por apresentar metodologia de testes padronizada, optou-se por utilizar o D. rerio neste trabalho, apesar de não ser uma espécie nativa do Brasil.

\subsubsection{Manutenção dos organismos em laboratório}

Juvenis de $D$. rerio foram obtidos comercialmente em uma loja especializada em aquários (Cemusiquário) da cidade de São Carlos e mantidos em laboratório por um período mínimo de 1 semana antes da realização dos bioensaios (para aclimatação), conforme recomendado pela norma ABNT (2003).

Lotes homogêneos de organismos foram mantidos em aquários de $25 \mathrm{~L}$, sob aeração constante, sendo preservada a proporção de, no máximo, $1 \mathrm{~g}$ de organismo por litro de água.

A água de manutenção, oriunda de poço artesiano, foi filtrada e ajustada para $\mathrm{pH}$ entre 7,0 e 7,6 e dureza de 40 a $48 \mathrm{mgCaCO}_{3} / \mathrm{L}$. Os organismos foram mantidos a uma temperatura de 23 a $27^{\circ} \mathrm{C}$ e fotoperíodo de $12 \mathrm{~h}$ luz, com luminosidade difusa.

A alimentação, constituída por ração comercial Tetramin, era fornecida duas vezes ao dia.

\subsubsection{Bioensaios de toxicidade aguda com amostras de esgoto utilizando de $D$. rerio como organismo-teste}

Os bioensaios com $D$. rerio seguiram metodologia de testes padronizada pela CETESB, norma L5.019 (1992). Os testes são agudos, semi-estáticos (renovação da amostra a cada 48h) e com 96 horas de duração, sendo que o efeito observado é a mortalidade.

Para cada um dos tratamentos e para o controle, são preparadas 3 réplicas contendo $250 \mathrm{~mL}$ de amostra e 5 peixes juvenis com idade entre 10 a 15 dias (mantendo a proporção de $1 \mathrm{~g}$ de 
organismo por litro de amostra). A água do controle utilizada no teste é a mesma do cultivo. Durante o teste não é fornecida alimentação nem aeração e o fotoperíodo é de 12 horas/luz. A temperatura pode variar de 23 a $27^{\circ} \mathrm{C}$ ao longo do bioensaio.

No início e final dos testes foram verificados o $\mathrm{pH}$, oxigênio dissolvido, dureza e condutividade das amostras e do controle.

\subsubsection{Allium cepa (Alliaceae)}

A cebola comum, pertencente à família das Liliáceas, é uma das plantas cultivadas de mais ampla difusão no mundo, sendo a segunda hortaliça em importância econômica, com valor da produção estimado em US\$ 6 bilhões anuais. Sua cultura teve origem no centro da Ásia de onde se espalhou para a África e Europa. No Brasil a introdução da cebola se deu principalmente através do Rio Grande do Sul.

Allium cepa (figura 5.14), apesar de não ser um organismo aquático e, por isso, não apresentar relevância ecológica em relação ao corpo hídrico receptor do esgoto a ser testado, foi escolhida como organismo-teste neste estudo por apresentar metodologia de teste simples, rápida e de baixo custo e por ser uma espécie que pode, eventualmente, ser cultivada por pequenos agricultores ribeirinhos que aproveitam as águas dos rios para irrigação.

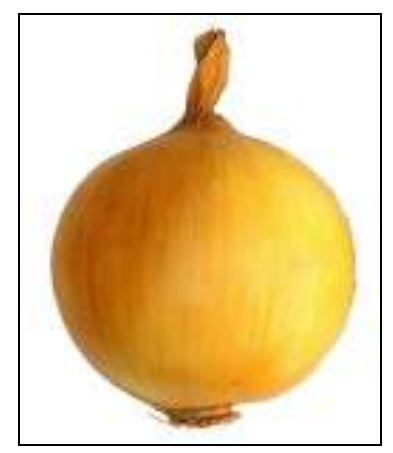

Figura 5.14. Allium cepa.

A. cepa tem sido utilizada como sistema de testes para investigar efeitos deletérios de diversas substâncias químicas, efluentes líquidos e amostras ambientais de água desde 1975 (RIBEIRO, 1999), sendo que seu uso tem sido recomendado por agências internacionais de proteção ambiental para verificação preliminar do nível de toxicidade de misturas complexas (FISKESJÖ, 1985). 


\subsubsection{Obtenção dos organismos}

Os bulbos de cebola utilizados neste estudo foram obtidos comercialmente no Mercado Municipal de São Carlos cerca de $24 \mathrm{~h}$ antes da realização dos ensaios de toxicidade e mantidos em laboratório, em ambiente ventilado, à temperatura ambiente.

Cumpre ressaltar que as cebolas selecionadas encontravam-se em bom estado de conservação (sem traumas ou deformidades externas visíveis) e apresentavam diâmetro entre 2,5 e $3,5 \mathrm{~cm}$ e peso entre $17 \mathrm{e} 30 \mathrm{~g}$.

\subsubsection{Bioensaios de toxicidade aguda com amostras de esgoto utilizando de $A$. cepa como organismo-teste}

Neste trabalho foi seguida a metodologia de testes de toxicidade para Allium cepa (teste I) desenvolvida por Fiskejö (1993).

Cerca de $3 \mathrm{~h}$ antes do início dos ensaios, as folhas mortas dos bulbos de cebola, bem como suas raízes secas foram removidas com faca de forma cuidadosa para não danificar a área radicular. As cebolas permaneceram em água destilada até o início dos testes a fim de que se reduzissem os possíveis efeitos inibidores do brotamento.

O bioensaio consiste na exposição de 12 bulbos de cebola de tamanho uniforme (diâmetro de 2,5 a $3,5 \mathrm{~cm}$ e peso de 17 a $30 \mathrm{~g}$ ) e de forma individual à amostra por um período de 72 horas, conforme pode ser visualizado na figura 5.15. As duas cebolas que apresentam menor crescimento da raiz nas primeiras 48 horas de teste são descartadas. As raízes das cebolas são mensuradas ao final do teste com um paquímetro e um valor médio do comprimento dos feixes das raízes de cada tratamento deve ser reportado; portanto, o efeito observado nesse bioensaio é a inibição do crescimento das raízes. Este teste, que é semi-estático (com renovação parcial de água a cada 24h), deve ser mantido sem iluminação nem aeração e em temperatura de $22 \pm 2^{\circ} \mathrm{C}$.

A porcentagem de inibição do crescimento da raíz da cebola foi calculada pela seguinte fórmula:

$$
I=\frac{C-M t}{C} \cdot 100
$$

I = inibição do crescimento da raíz da cebola (\%)

$\mathrm{C}=$ comprimento médio das raízes de cebolas do controle

$\mathrm{M}_{\mathrm{t}}=$ comprimento médio das raízes de cebolas do tratamento 


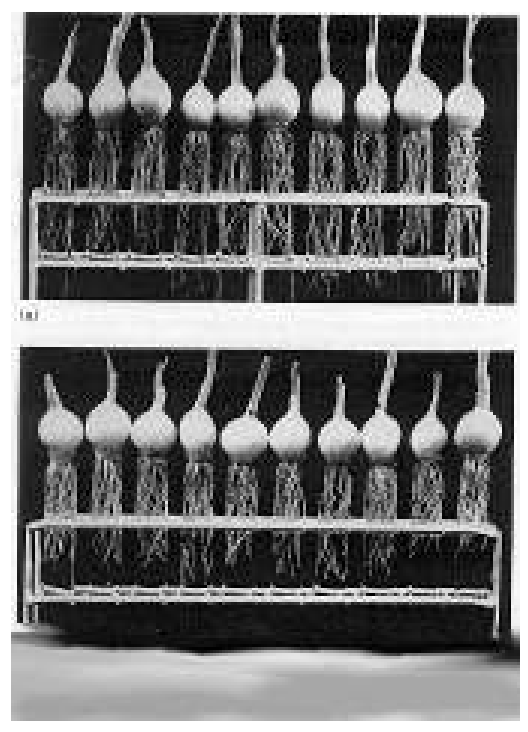

Figura 5.15. Teste de toxicidade com bulbos de cebola (Allium cepa).

Acima: controle. Abaixo: solução a 1\% de metanol. Fonte: Fiskejö (1993).

No início e final dos testes foram verificados os valores de $\mathrm{pH}$, oxigênio dissolvido, dureza e condutividade das amostras e do controle.

\subsubsection{Bioensaios de toxicidade com cloro, ácido peracético e radiação ultravioleta}

Para avaliar a sensibilidade dos diferentes organismos-teste ao hipoclorito de sódio, ácido peracético e radiação ultravioleta, foram realizados testes de toxicidade que, para D. similis, D. rerio e A. серa, seguiram as respectivas metodologias descritas nos bioensaios com amostras de esgoto. Nesse caso, no entanto, os organismos foram expostos a diferentes concentrações ou dosagens (no caso da radiação ultravioleta) dos agentes desinfetantes, diluídas com água reconstituída.

Para C. silvestrii e C. xanthus, as metodologias de testes com os agentes de desinfecção diferiram dos respectivos métodos de bioensaios utilizados com amostras de esgoto.

Os testes de toxicidade realizados nesse momento com $C$. silvestrii foram estáticos, agudos, com duração de 48 horas, sem fornecimento de alimento nem aeração, sendo o fotoperíodo de $24 \mathrm{~h}$ escuro e com a temperatura variando entre 23 e $25^{\circ} \mathrm{C}$. Para cada uma das concentrações-teste ou doses-teste, foram preparadas 4 réplicas, contendo 5 organismos em $20 \mathrm{~mL}$ de solução.

Já os testes com C. xanthus foram estáticos, agudos, com duração de 96h, com a adição de alimento a cada $48 \mathrm{~h}$, mas sem fornecimento de aeração, sendo mantidos o fotoperíodo e a temperatura utilizados nos cultivos. Para cada uma das concentrações-teste ou doses-teste, foram preparadas 10 réplicas, contendo 1 organismo em 30mL de solução, sem a presença de substrato. 
Após o término de cada experimento, foi observado o endpoint específico para os organismos-teste (mortalidade ou imobilidade) nas diferentes concentrações ou doses testadas e, quando possível, calculada a CL50 ou CE50 (concentração da amostra que causa efeito agudo, letal ou não, a 50\% dos organismos-teste, no tempo de exposição e nas condições de ensaio), assim como seu intervalo de confiança $(\mathrm{p}=0,05)$, por meio do método Trimmed Spearman-Karber (HAMILTON, 1977) ou por meio de interpolação gráfica, no caso dos testes realizados com $A$. cepa.

$\mathrm{Na}$ tabela 5.4 estão discriminadas as faixas de concentração utilizadas nos testes de toxicidade com os diferentes organismos-teste.

Tabela 5.4. Faixas de concentrações ou doses (recebidas) dos agentes tóxicos utilizadas em testes de toxicidade neste estudo.

\begin{tabular}{|l|c|c|c|}
\hline Organismo-teste & Hipoclorito de sódio & Ácido Peracético & Radiação Ultravioleta \\
\hline D. similis & 0,005 a $0,08 \mathrm{mg} / \mathrm{L}$ & 0,1 a $1,2 \mathrm{mg} / \mathrm{L}$ & 78,31 a $313,26 \mathrm{mWs} / \mathrm{cm}^{2}$ \\
\hline C. silvestrii & 0,005 a $0,04 \mathrm{mg} / \mathrm{L}$ & 0,1 a $1,2 \mathrm{mg} / \mathrm{L}$ & 78,31 a $313,26 \mathrm{mWs} / \mathrm{cm}^{2}$ \\
\hline D. rerio & 0,02 a $4,80 \mathrm{mg} / \mathrm{L}$ & 0,4 a $4,2 \mathrm{mg} / \mathrm{L}$ & 78,31 a $313,26 \mathrm{mWs} / \mathrm{cm}^{2}$ \\
\hline C. xanthus & 0,16 a $2,56 \mathrm{mg} / \mathrm{L}$ & 0,2 a $6,0 \mathrm{mg} / \mathrm{L}$ & 78,31 a $313,26 \mathrm{mWs} / \mathrm{cm}^{2}$ \\
A. cepa & 0,32 a $5,00 \mathrm{mg} / \mathrm{L}$ & 1,0 a $10,0 \mathrm{mg} / \mathrm{L}$ & 78,31 a $313,26 \mathrm{mWs} / \mathrm{cm}^{2}$ \\
\hline
\end{tabular}

No início e final dos ensaios foram verificados os valores de $\mathrm{pH}$, oxigênio dissolvido, dureza e condutividade dos tratamentos e do controle.

\subsubsection{Testes de sensibilidade à substância de referência}

Os testes de sensibilidade consistem em expor os organismos-teste a diferentes concentrações de uma determinada substância de referência. O objetivo desses ensaios é avaliar a repetibilidade do método analítico em um determinado laboratório ao longo do tempo e permitir comparações interlaboratoriais (ENVIRONMENT CANADA, 1990). Os resultados devem ser expressos por meio de cartas-controle, onde são calculadas as faixas de sensibilidade de cada organismo às substâncias de referência específicas. Os limites de aceitação de resultados devem estar compreendidos nas faixas de sensibilidade, sendo esses valores um dos indicadores da qualidade do ensaio ecotoxicológico.

Para D. similis, D. rerio e A. Cepa, os ensaios de sensibilidade foram realizados em conformidade com as respectivas metodologias descritas nos bioensaios com amostras de esgoto, sendo que o tempo de duração dos testes, em alguns casos, foi modificado. Já para $C$. silvestrii e $C$. xanthus, os testes seguiram metodologias descritas no item 5.5.6. As substâncias de referência 
utilizadas nos testes de sensibilidade, bem como as faixas de concentrações testadas são listadas na tabela 5.5.

Tabela 5.5. Características gerais dos testes de sensibilidade realizados com os organismos-teste.

\begin{tabular}{|l|c|c|c|}
\hline \multicolumn{1}{|c|}{ Espécie } & Substância de referência & Faixa de concentração & Duração do teste \\
\hline D. similis & Dicromato de Potássio & 0,01 a $0,30 \mathrm{mg} / \mathrm{L}$ & $24 \mathrm{~h}$ \\
C. silvestrii & Cloreto de Sódio & 0,4 a $2,8 \mathrm{mg} / \mathrm{L}$ & $48 \mathrm{~h}$ \\
\hline D. rerio & Dicromato de Potássio & 70,0 a $180 \mathrm{mg} / \mathrm{L}$ & $96 \mathrm{~h}$ \\
\hline C. xanthus & Cloreto de Potássio & 1,0 a $7,8 \mathrm{~g} / \mathrm{L}$ & $96 \mathrm{~h}$ \\
\hline A. cepa & Sulfato de Cobre & 0,05 a $1,35 \mathrm{mg} / \mathrm{L}$ & $72 \mathrm{~h}$ \\
\hline
\end{tabular}

Ao final de cada experimento, foi observada a mortalidade ou imobilidade total em cada concentração e no controle e calculada a CL50 (ou CE50), assim como seu Intervalo de Confiança a 95\%, através do método Trimmed Spearman-Karber (HAMILTON, 1977).

As faixas de sensibilidade para cada organismo foram determinadas a partir das médias de CL50 (ou CE50) \pm 2 desvios-padrão dos resultados de testes pretéritos.

No início e final dos ensaios foram verificados os valores de $\mathrm{pH}$, oxigênio dissolvido, dureza e condutividade dos tratamentos e do controle.

\subsubsection{Análises de dados dos bioensaios com amostras de esgoto}

Os resultados dos bioensaios com amostras de esgoto foram analisados por meio de testes de hipóteses. Primeiramente, os dados foram submetidos a testes de normalidade (teste de chiquadrado) e homocedasticidade (teste de Bartlett). Quando constatado que o conjunto de dados apresentava distribuição normal e homogeneidade de variâncias, verificava-se se havia alguma diferença estatística entre as médias dos tratamentos por meio de análise de variância (ANOVA). Caso positivo, havia a necessidade de comparar as médias de cada tratamento com a do controle experimental através do teste de Dunnett e/ou comparar todos os tratamentos entre si através do teste de Tukey (VIEIRA, 1999).

Porém, quando a normalidade dos dados ou homogeneidade de suas variâncias não era verificada, utilizava-se o teste de Steel Many One Rank (equivalente não paramétrico ao teste de Dunnett), depois o teste de Kruskal-Wallis para a realização de comparações múltiplas entre os tratamentos (NIPPER, 2002b).

Os resultados foram expressos em termos qualitativos, isto é, como "tóxicos" (tratamento estatísticamente diferente do controle) ou "não tóxicos" (tratamento estatísticamente igual ao controle). 
O programa computacional utilizado para executar as análises estatísticas foi o TOXSTAT 3.3 (GULLEY, 1994), sendo que o nível de significância de todos os testes utilizados para tratar os conjuntos de dados deste estudo foi de $5 \%(\alpha=0,05)$.

Para analisar os dados de reprodução de C. silvestrii, além dos testes estatísticos acima citados, também foi possível, em alguns casos, estimar a taxa intrínseca de crescimento populacional através da equação de aumento natural da população sob condições ótimas, sugerido por ALMEIDA et al. (2000), uma vez que as condições laboratoriais dos bioensaios permitiram essa extrapolação.

Com relação aos resultados de sobrevivência ou mobilidade obtidos nos bioensaios com diluições seriadas, foi possível, em alguns casos, calcular a CL50 ou CE50 (concentração que causa efeito deletério agudo a 50\% dos organismos-teste no tempo de exposição determinado), assim como seu intervalo de confiança $(\mathrm{p}=0,05)$ através do método Trimmed-Spearman-Karber (HAMILTON et al., 1978). Nos casos em que não foi possível calcular a CL50 ou CE50, os resultados dos testes foram expressos em termos de Concentração de Efeito Não Observado (CENO), isto é, a maior concentração da amostra que não causa efeito deletério estatísticamente significativo na sobrevivência e reprodução dos organismos-teste, nas condições de ensaio. 


\section{RESULTADOS E DISCUSSÕES}

Nesse tópico, serão apresentados e discutidos primeiramente os resultados obtidos na coleta preliminar (efetuada em setembro de 2003), estabelecendo uma comparação entre as características do esgoto bruto e tratado da ETE-Araraquara. Em um segundo momento, serão expostos e comparados os resultados das análises físicas, químicas, bacteriológicas e toxicológicas do esgoto coletado nas 4 amostragens, a fim de analisar a variabilidade do efluente ao longo do tempo. Os dados obtidos nos diferentes ensaios de desinfecção com amostras de esgoto da $2^{\mathrm{a}}, 3^{\mathrm{a}}$ e $4^{\mathrm{a}}$ coletas serão apresentados na seqüência, bem como os bioensaios de toxicidade com amostras de esgoto após a desinfecção. Por fim, serão descritos os resultados dos testes de sensibilidade aos desinfetantes isoladamente e à substâncias de referência.

\subsection{Caracterização física, química e bacteriológica do esgoto bruto e tratado da ETE- Araraquara: coleta preliminar}

O objetivo dessa primeira coleta, realizada em 15/9/2003, foi o de analisar as características físicas, químicas e bacteriológicas gerais do esgoto sanitário bruto (afluente da ETE) e tratado (efluente da ETE) de Araraquara e estimar seu potencial tóxico a diferentes organismos-teste.

$\mathrm{Na}$ tabela 6.1, são apresentados os resultados obtidos nessa coleta preliminar, bem como a eficiência do tratamento de esgoto em termos de remoção de nutrientes, matéria orgânica, coliformes e outros parâmetros. 
Tabela 6.1. Resultados das análises físicas, químicas e bacteriológicas realizadas em amostras de esgoto afluente e efluente da ETE - Araraquara coletadas em 15/09/03.

\begin{tabular}{|c|c|c|c|c|}
\hline Parâmetros & Unidade & Afluente & Efluente & $\begin{array}{l}\text { Eficiência de } \\
\text { Remoção (\%) } \\
\end{array}$ \\
\hline Vazão & $\mathbf{L} / \mathbf{s}$ & 495 & 500 & - \\
\hline Turbidez & NTU & 418 & 80 & 80,9 \\
\hline Temperatura & ${ }^{\circ} \mathrm{C}$ & 25,8 & 21,8 & - \\
\hline pH & & 7,5 & 7,7 & - \\
\hline Condutividade & $\mu \mathrm{S} / \mathrm{cm}$ & 607 & 436 & 28,3 \\
\hline OD & $\mathrm{mg} / \mathrm{L}$ & 2,5 & 8,4 & - \\
\hline Dureza & $\mathrm{mgCaCO}_{3} / \mathrm{L}$ & 340 & 58 & 82,9 \\
\hline Cloreto & $\mathrm{mg} / \mathrm{L}$ & 33,6 & 41,4 & - \\
\hline Sulfeto & $\mathrm{mg} / \mathrm{L}$ & 0,21 & 0,05 & 76,2 \\
\hline Sulfato & $\mathrm{mg} / \mathrm{L}$ & 74 & 50 & 32,4 \\
\hline ST & $\mathrm{mg} / \mathrm{L}$ & 710 & 450 & 36,6 \\
\hline SST & $\mathrm{mg} / \mathrm{L}$ & 116 & 34 & 70,3 \\
\hline SDT & $\mathrm{mg} / \mathrm{L}$ & 608 & 416 & 31,7 \\
\hline NTK & $\mathrm{mg} / \mathrm{L}$ & 38,08 & 14,32 & 62,4 \\
\hline Amônia & $\mathrm{mg} / \mathrm{L}$ & 22,22 & 10,68 & 51,9 \\
\hline Nitrito & $\mathrm{mg} / \mathrm{L}$ & 0,04 & 2,80 & - \\
\hline Nitrato & $\mathrm{mg} / \mathrm{L}$ & 0,19 & 3,27 & - \\
\hline Fósforo total & $\mathrm{mg} / \mathrm{L}$ & 8,07 & 6,42 & 20,5 \\
\hline Fosfato total dissolvido & $\mathrm{mg} / \mathrm{L}$ & 6,05 & 5,10 & 15,8 \\
\hline Fosfato inorgânico & $\mathbf{m g} / \mathbf{L}$ & 5,41 & 5,04 & 6,8 \\
\hline Silicato & $\mathrm{mg} / \mathrm{L}$ & 29,2 & 27,5 & 5,8 \\
\hline $\mathbf{P b}$ & $\mathrm{mg} / \mathrm{L}$ & 0,0310 & ND & - \\
\hline $\mathrm{Cr}$ & $\mathrm{mg} / \mathrm{L}$ & 0,0145 & 0,0225 & - \\
\hline Cd & $\mathrm{mg} / \mathrm{L}$ & ND & ND & - \\
\hline $\mathrm{Cu}$ & $\mathrm{mg} / \mathrm{L}$ & 0,0095 & ND & - \\
\hline Zn & $\mathrm{mg} / \mathrm{L}$ & 0,1791 & 0,0360 & 79,9 \\
\hline $\mathbf{N i}$ & $\mathrm{mg} / \mathrm{L}$ & ND & ND & - \\
\hline $\mathbf{F e}$ & $\mathrm{mg} / \mathrm{L}$ & 3,4845 & 1,9760 & 43,3 \\
\hline Mn & $\mathrm{mg} / \mathrm{L}$ & 0,0865 & 0,0475 & 45,1 \\
\hline $\mathrm{Ca}$ & $\mathrm{mg} / \mathrm{L}$ & 5,7565 & 9,5949 & - \\
\hline Mg & $\mathrm{mg} / \mathrm{L}$ & 0,9593 & 0,9057 & 5,6 \\
\hline COT & $\mathrm{mg} / \mathrm{L}$ & 126 & 25 & 80,0 \\
\hline DQO & $\mathrm{mg} / \mathrm{L}$ & 390 & 160 & 59,0 \\
\hline $\mathrm{DBO}_{5}$ & $\mathrm{mg} / \mathrm{L}$ & 148,8 & 64,4 & 56,7 \\
\hline Coliformes totais & NMP/100ml & $10,95 \times 10^{6}$ & $12,59 \times 10^{5}$ & 88,5 \\
\hline E. coli & NMP/100ml & $3,24 \times 10^{6}$ & $2,09 \times 10^{5}$ & 93,5 \\
\hline
\end{tabular}

- : Não Determinado.

ND: Não Detectado.

Vermelho: abaixo do limite de detecção (LD) do equipamento.

Azul: abaixo do limite de quantificação (LQ) do equipamento. 
O sistema de tratamento da ETE-Araraquara é de nível secundário, sendo constituído por lagoas de estabilização.

Inicialmente, ocorre o tratamento preliminar ou físico, que é composto por um sistema de gradeamento e caixas de areia mecanizadas e tem por finalidade remover os detritos em suspensão mais grosseiros que chegam à estação. A seguir, ocorre o tratamento secundário (biológico), que é feito por meio de lagoas aeradas de mistura completa e tem como objetivo principal a remoção de matéria orgânica do esgoto, podendo, inclusive promover a remoção de alguns nutrientes.

Nas lagoas aeradas, onde o tempo de detenção do esgoto é de cerca de 3 dias, o processo de decomposição da matéria orgânica se dá através da atividade de organismos heterótrofos aeróbios (bactérias, fungos, rotíferos, etc.) que oxidam e degradam óleos, graxas, carboidratos e proteínas, formando água e gás carbônico. Além da remoção desses compostos carbonáceos, bactérias autótrofas quimiossintetizantes são responsáveis pelo processo de nitrificação do esgoto, formando nitritos e nitratos, o que pode justificar o aumento das concentrações desses nutrientes no efluente após o tratamento, conforme verificado neste estudo (tabela 6.1).

Como a energia introduzida nas lagoas aeradas de mistura completa é elevada, o efluente contém altos teores de sólidos em suspensão nesse momento. Daí a necessidade de haver as lagoas de sedimentação à jusante, onde o esgoto permanece em descanso por aproximadamente 1,7 dias para que as partículas sólidas ainda presentes na mistura sejam sedimentadas por gravidade, possibilitando a clarificação do efluente devido a remoção da matéria orgânica da coluna d'água.

Analisando os dados da tabela 6.1, pode-se verificar melhoria da qualidade do efluente tratado em função da eficiência da ETE na remoção de sólidos, sulfetos, sulfatos, silicato, nitrogênio total Kjeldahl (NTK), amônia, fósforo total, carbono orgânico total (COT), demanda química de oxigênio (DQO), demanda bioquímica de oxigênio $\left(\mathrm{DBO}_{5}\right)$, coliformes totais e E. coli, além da redução das concentrações de ferro, zinco, manganês e magnésio e promoção da oxigenação do esgoto (acréscimo de 70,8\% de oxigênio dissolvido em relação ao afluente).

A título de comparação, é apresentada a tabela 6.2 com os resultados obtidos neste estudo e no trabalho realizado por Scalize (2003), no ano de 2002, para amostras de esgoto coletadas na mesma ETE-Araraquara. 
Tabela 6.2. Comparação entre os dados físicos, químicos e bacteriológicos do esgoto bruto e tratado da ETE-Araraquara obtidos por Scalize (2003) no ano de 2002 e por este estudo no ano de 2003.

\begin{tabular}{|c|c|c|c|c|c|}
\hline Parâmetros & Unidade & $\begin{array}{c}\text { Afluente } \\
\text { (2002) }\end{array}$ & $\begin{array}{c}\text { Afluente } \\
\text { (2003) }\end{array}$ & $\begin{array}{c}\text { Efluente } \\
\text { (2002) }\end{array}$ & $\begin{array}{c}\text { Efluente } \\
\text { (2003) }\end{array}$ \\
\hline Turbidez & NTU & - & 418 & 90 & 80 \\
\hline pH & & 6,8 & 7,5 & 7,2 & 7,7 \\
\hline Condutividade & $\mu \mathrm{S} / \mathrm{cm}$ & 543 & 608 & 522 & 436 \\
\hline OD & $\mathrm{mg} / \mathrm{L}$ & - & 2,46 & 5,60 & 8,45 \\
\hline Cloreto & $\mathrm{mg} / \mathrm{L}$ & 43,7 & 33,6 & 45,3 & 41,4 \\
\hline ST & $\mathrm{mg} / \mathrm{L}$ & 646 & 710 & 363 & 450 \\
\hline SST & $\mathrm{mg} / \mathrm{L}$ & 247 & 116 & 53 & 34 \\
\hline SDT & $\mathrm{mg} / \mathrm{L}$ & 540 & 608 & 315 & 416 \\
\hline NTK & $\mathrm{mg} / \mathrm{L}$ & 34,00 & 38,08 & 20,60 & 14,32 \\
\hline Amônia & $\mathrm{mg} / \mathrm{L}$ & 16,31 & 22,22 & 13,79 & 10,68 \\
\hline Nitrito & $\mathrm{mg} / \mathrm{L}$ & 0,12 & 0,04 & 1,83 & 2,80 \\
\hline Nitrato & $\mathrm{mg} / \mathrm{L}$ & 0,40 & 0,19 & 2,24 & 3,27 \\
\hline Fósforo Total & $\mathrm{mg} / \mathrm{L}$ & 8,00 & 8,07 & 6,30 & 6,42 \\
\hline DQO & $\mathrm{mg} / \mathrm{L}$ & 730 & 390 & 141 & 160 \\
\hline $\mathrm{DBO}_{5}$ & $\mathrm{mg} / \mathrm{L}$ & 327,2 & 148,8 & 63,4 & 64,4 \\
\hline${\mathrm{DQO} / \mathrm{DBO}_{5}}_{4}$ & & 2,23 & 2,62 & 2,23 & 2,49 \\
\hline Coliformes totais & NMP/100ml & - & $10,95 \times 10^{6}$ & $1,50 \times 10^{6}$ & $1,26 \times 10^{6}$ \\
\hline E. coli & NMP/100ml & - & $32,4 \times 10^{5}$ & $3,30 \times 10^{5}$ & $2,09 \times 10^{5}$ \\
\hline
\end{tabular}

- : Não Determinado.

Pode-se observar que, para o esgoto bruto (afluente), os valores de $\mathrm{pH}$, condutividade, sólidos totais e dissolvidos, NTK e amônia obtidas neste estudo foram superiores às encontradas por Scalize (2003), enquanto que as medidas de DQO e DBO foram bastante inferiores às do referido autor.

Já para o esgoto tratado (efluente), as concentrações de fósforo total, $\mathrm{DQO}$ e $\mathrm{DBO}_{5}$ foram equivalentes para os dois estudos, enquanto que as medidas de coliformes totais, E. coli, NTK e amônia obtidas neste estudo foram inferiores às encontradas por Scalize (2003).

$\mathrm{Na}$ figura 6.1, pode ser observada a distribuição das formas de nitrogênio encontradas no esgoto bruto e tratado da ETE-Araraquara nos anos de 2002 e 2003. 

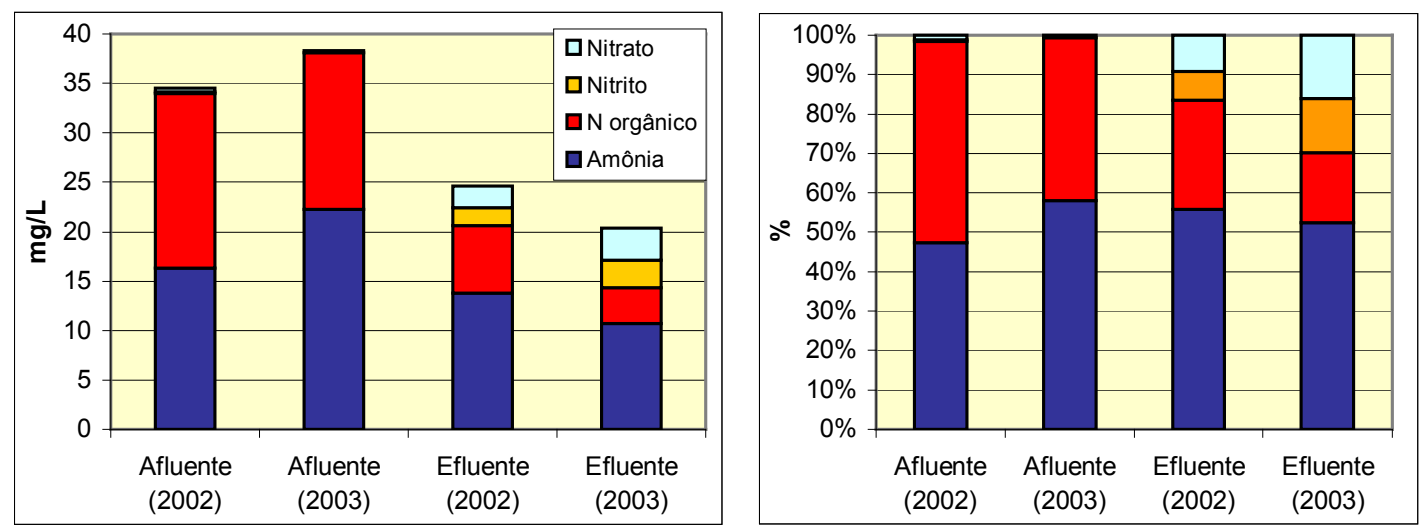

Figura 6.1. Distribuição das formas de nitrogênio encontradas no esgoto bruto (afluente) e tratado (efluente) da ETE-Araraquara nos anos de 2002 (SCALIZE, 2003) e 2003 (presente estudo).

Nota-se que, no esgoto bruto, a fração de nitrito e nitrato é desprezível quando comparada às frações de amônia e nitrogênio orgânico, o que era esperado para um esgoto predominantemente doméstico, onde a maior parte do NTK tem origem fisiológica. Já para o efluente tratado, as concentrações de nitrito e nitrato são mais significativas.

Ao analisar a eficiência do sistema de tratamento de esgotos da ETE-Araraquara nos anos de 2002 e 2003 (figura 6.2), pode-se verificar que a remoção de nitrogênio total Kjeldahl e amoniacal foi superior para o ano de 2003 em relação ao ano de 2002. Para os outros parâmetros analisados, a eficiência da ETE foi maior no ano de 2002.

Merece especial atenção a eficiência do tratamento de esgotos na remoção de DBOs e DQO observada neste estudo, a qual mostrou-se baixa (de apenas 56,73\% e 58,97\%, respectivamente) quando comparada a trabalhos anteriores. Durante o período de outubro de 1999 a setembro de 2001, a eficiência dessa mesma ETE em termos de remoção de $\mathrm{DBO}_{5}$ apresentou um valor médio superior a $84 \%$ (PIERRI, 2001), sendo que em 2002, sua eficiência foi de $80,6 \%$ tanto para DBO5 como para DQO (figura 6.2). Nota-se, no entanto, que nos estudos anteriores, as concentrações de DBO5 e DQO no esgoto bruto foram cerca de duas vezes superiores às encontradas no presente trabalho, o que pode ter ocasionado, em termos proporcionais, a discrepância na eficiência do tratamento dos esgotos encontrada nos diferentes estudos. 




Figura 6.2. Eficiência da ETE-Araraquara na remoção de sólidos, $\mathrm{DQO}, \mathrm{DBO}_{5}$, Nitrogênio total e amoniacal e Fósforo total no ano de 2002 (SCALIZE, 2003) e 2003 (presente estudo).

Mesmo assim, considerando que, de acordo com o Decreto Estadual N 8.468/76, o limite de lançamento de $\mathrm{DBO}_{5}$ em águas de classe 4 é de $60 \mathrm{mg} / \mathrm{L}$, sendo que esse valor pode ser ultrapassado no caso de efluentes de sistemas de tratamento que reduzam a carga poluidora em, no mínimo, 80\%, observou-se que o efluente da ETE-Araraquara, neste estudo, não atingiu nenhum dos dois critérios.

Outro parâmetro que indica a baixa eficiência da ETE-Araraquara na remoção de matéria orgânica biodegradável no ano de 2003 é a relação entre DQO/DBO 5 (figura 6.3).

Segundo Von Sperling (2005), quanto mais baixa a relação $\mathrm{DQO} / \mathrm{DBO}_{5}$, maior é a fração de matéria orgânica biodegradável em relação à matéria orgânica química oxidável (e de mais difícil degradação biológica) presente no esgoto. Sendo assim, nos casos de sistemas de tratamento biológico de águas residuárias, há uma tendência do valor dessa relação aumentar à medida que o esgoto passa pelas diversas unidades da estação de tratamento, devido à redução paulatina da fração biodegradável, ao passo que a fração inerte do esgoto permanece praticamente inalterada.

Nesse sentido, o esgoto doméstico bruto (afluente), com fração biodegradável elevada, possui valores da relação $\mathrm{DQO} / \mathrm{DBO}_{5}$ abaixo de 2,5 (em torno de 1,7 a 2,4 - mediana de 2,1); enquanto que o efluente final de uma ETE com tratamento biológico possui valores da relação DQO/DBO 5 em torno de 2,5, podendo chegar a 4,0 (VON SPERLING, op.cit.).

$\mathrm{Na}$ figura 6.3, pode-se observar que Scalize (2003) encontrou valores semelhantes de relação $\mathrm{DQO} / \mathrm{DBO}_{5}$ para o afluente e o efluente da ETE-Araraquara no ano de 2002. Neste estudo, no entanto, essa relação foi inferior para o efluente tratado em relação ao afluente, indicando que a eficiência da ETE na remoção da fração biodegradável ficou aquém do esperado. 


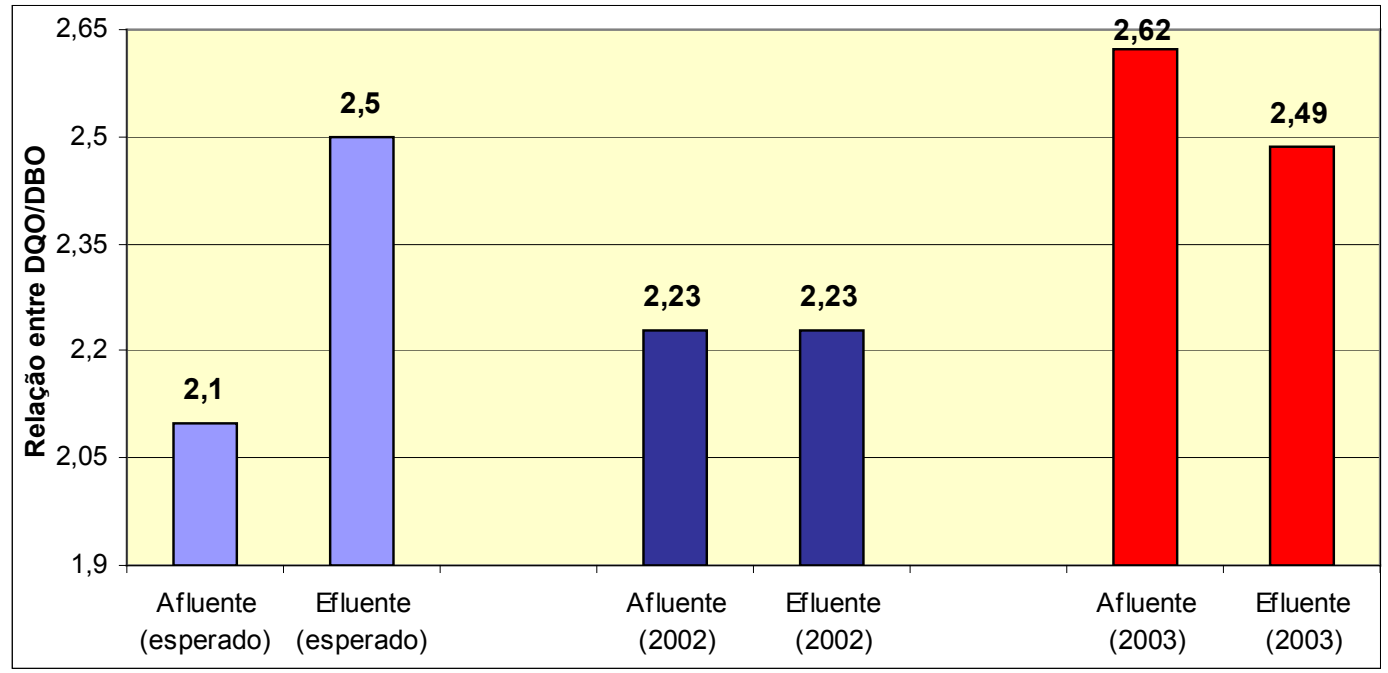

Figura 6.3. Estimativa de valores da relação entre $\mathrm{DQO} / \mathrm{DBO}_{5}$ para o esgoto doméstico bruto (afluente) e tratado (efluente) e valores encontrados para a ETE-Araraquara nos anos de 2002 (SCALIZE, 2003) e 2003 (presente estudo).

Deve-se notar que, no presente trabalho, o valor para a relação $\mathrm{DQO} / \mathrm{DBO}_{5}$ do afluente foi de 2,62, indicando que sua fração biodegradável não era elevada, o que pode ter acarretado menor eficiência do sistema de tratamento biológico.

Cabe ressaltar que o esgoto que chega à ETE-Araraquara é sanitário. Isso significa que, além do despejo líquido resultante do uso da água para higiene e necessidades fisiológicas humanas (esgoto doméstico), o esgoto também pode ser composto por despejo líquido resultante dos processos industriais (esgoto industrial), pela água proveniente do subsolo que penetra nas canalizações (água de infiltração) e por uma parcela do deflúvio superficial inevitavelmente absorvida pela rede de esgotamento (contribuição pluvial parasitária), o que pode ocasionar acréscimo na fração inerte do efluente, dificultando a sua tratabilidade quando a ETE é constituída por sistema de tratamento biológico.

Acredita-se que a eficiência do sistema de tratamento de esgotos de Araraquara na remoção de DQO e $\mathrm{DBO}_{5}$ no ano de 2003 também ficou prejudicada pela quebra de alguns aeradores responsáveis pelo tratamento secundário da ETE, conforme informado pelo Departamento Autônomo de Água e Esgotos (DAAE) de Araraquara, entidade responsável pela operação da Estação.

A quebra dos aeradores, no entanto, não parece ter prejudicado a eficiência da ETEAraraquara em reduzir as concentrações de coliformes totais $(88,5 \%)$ e E.coli $(93,55 \%)$ no ano de 2003 (tabela 6.1 e figura 6.4), uma vez que a expectativa de eficiência dessa modalidade de sistema de tratamento de esgoto varia entre 80 e $99 \%$. 


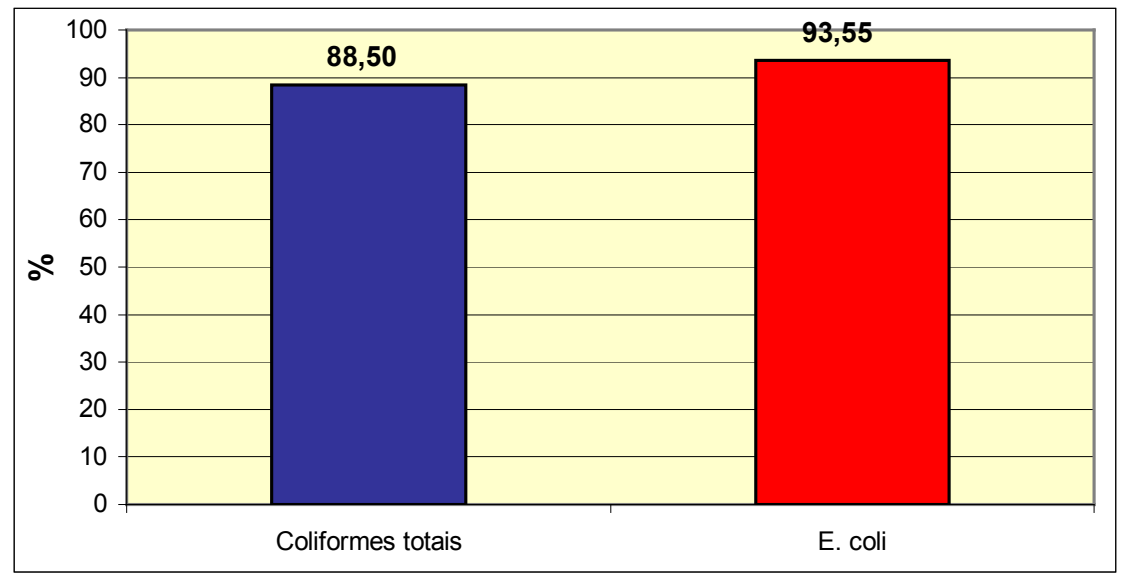

Figura 6.4. Eficiência da ETE-Araraquara na remoção de Coliformes totais e E.coli no ano de 2003.

Da mesma forma, as concentrações dos parâmetros físicos e químicos analisados neste estudo, para o esgoto tratado, encontram-se dentro dos limites estabelecidos pelas Resoluções do CONAMA ( ${ }^{\circ} 20 / 86$ e N 357/2005) e pelo Decreto Estadual № 8.468/76 para corpos d'água de classe 4 , já que a qualidade requerida para os usos preponderantes desses recursos hídricos (navegação e harmonia paisagística) são os menos exigentes possíveis. Exceção seja feita para o nitrogênio amoniacal, cuja concentração no esgoto tratado extrapolou o limite máximo de lançamento de $5 \mathrm{mg} / \mathrm{L}$ determinado pelo Decreto Estadual $\mathrm{N}^{\circ} 8.468 / 76$, o qual estabelece padrões de lançamento mais restritivos do que as Resoluções do CONAMA ( $N^{\circ}$ 20/86 e $\mathrm{N}^{\circ}$ 357/2005). O mesmo ocorreu para a $\mathrm{DBO}$, conforme mencionado anteriormente.

\subsubsection{Avaliação ecotoxicológica do esgoto bruto e tratado da ETE-Araraquara: coleta preliminar}

Com relação ao potencial tóxico do esgoto coletado em 15/9/2003, a melhoria da qualidade do efluente tratado em relação ao esgoto bruto proporcionou significativa redução da sua toxicidade, evidenciada por meio dos bioensaios com D. rerio e C. xanthus, conforme tabelas 6.3 e 6.4 e tabelas A-I.1, A-I.2, A-I.3 e A-I.4 (Anexo I). 
Tabela 6.3. Concentração de Efeito Não Observado (CENO) da amostra de esgoto bruto (afluente) e tratado (efluente).

\begin{tabular}{lcccc}
\hline \multirow{2}{*}{ Organismos-teste } & \multirow{2}{*}{$\begin{array}{c}\text { Efeito } \\
\text { observado }\end{array}$} & \multirow{2}{*}{$\begin{array}{c}\text { Tempo de } \\
\text { exposição (h) }\end{array}$} & \multicolumn{2}{c}{ CENO* } \\
\cline { 5 - 5 } & & & Afluente & Efluente \\
\hline D.similis & Imobilidade & 48 & $100 \%$ & $100 \%$ \\
D. rerio & Mortalidade & 96 & $50 \%$ & $100 \%$ \\
C. xanthus & Mortalidade & 168 & $25 \%$ & $100 \%$ \\
C. silvestrii & Imobilidade & 168 & - & $25 \%$ \\
\hline
\end{tabular}

*CENO: a maior concentração da amostra que não causa efeito deletério aos organismos-teste. Quanto menor, mais tóxico.

Tabela 6.4. Concentração do esgoto que causou efeito deletério a $50 \%$ dos organismos nos tempos de exposição determinados.

\begin{tabular}{|c|c|c|c|c|}
\hline \multirow{2}{*}{$\begin{array}{c}\text { Organismos- } \\
\text { teste }\end{array}$} & \multirow{2}{*}{$\begin{array}{c}\text { Efeito } \\
\text { Observado }\end{array}$} & \multirow{2}{*}{$\begin{array}{c}\text { Tempo de } \\
\text { exposição (h) }\end{array}$} & \multicolumn{2}{|c|}{ CE ou CL $50(\%)$} \\
\hline & & & Afluente & Efluente \\
\hline D. similis & Imobilidade & 48 & $\mathrm{NC}$ & $\mathrm{NC}$ \\
\hline D. rerio & Mortalidade & 48 & 61,24 & $\mathrm{NC}$ \\
\hline C. xanthus & Mortalidade & 168 & 51,63 & $\mathrm{NC}$ \\
\hline C. silvestrii & Imobilidade & 144 & 62,29 & 38,67 \\
\hline
\end{tabular}

IC: 55,46 a $69,96 \%$ IC: 34,19 a $43,74 \%$

NC: Não Calculável

IC: Intervalo de Confiança com coeficiente de confiança de $95 \%$.

O esgoto bruto (concentração de 100\%) causou toxicidade aguda em todos os organismosteste com exceção de $D$. similis, para o qual foi observado indício de toxicidade. Para $D$. rerio e $C$. silvestrii (tabelas A-I.2 e A-I.4), foram verificados $100 \%$ de mortalidade nas primeiras $24 \mathrm{~h}$ de exposição ao esgoto. Já para D. similis e C. xanthus (tabelas A-I.1 e A-I.3), foram observados 20\% de imobilidade e $70 \%$ de mortalidade, respectivamente, durante $48 \mathrm{~h}$ de exposição. Sendo assim, é possível concluir que até a comunidade bentônica pode ser afetada com o lançamento de esgoto in natura nos corpos hídricos receptores.

Com relação à amostra integral do esgoto tratado (concentração de 100\%), somente foi verificado efeito tóxico para $C$. silvestrii, que sofreu mortalidade de $20 \%$ nas primeiras $48 \mathrm{~h}$ de exposição, $80 \%$ em $96 \mathrm{~h}$ e 100\% em 144h de exposição. Para os outros organismos, não foi observada mortalidade ou imobilidade durante os respectivos períodos de teste.

Portanto, tomando como base os bioensaios realizados com afluente e efluente integrais, observou-se redução da toxicidade do efluente em relação ao afluente para todos os organismos 
estudados. Para C. xanthus e D. rerio, por exemplo, o teste estatístico de Kruskal-Wallis $(\alpha=0,05)$ identificou diferença significativa entre o afluente $100 \%$ e o efluente $100 \%$. Para C. silvestrii, o efeito deletério agudo do efluente puro foi visivelmente inferior ao do afluente puro, considerando o período de exposição de $48 \mathrm{~h}$.

Esse mesmo padrão foi evidenciado nos bioensaios com diferentes concentrações do afluente e efluente $(25 \%, 50 \%$ e $75 \%)$ utilizando D. similis, D. rerio e C. xanthus como organismos-alvo. Entretanto, nos testes com C. silvestrii, verificou-se que as amostras de efluente a $25 \%$ e $50 \%$ ocasionaram maior efeito tóxico a esse organismo (em termos de reprodução) do que as mesmas concentrações do afluente. Ressalta-se que o afluente $25 \%$ foi o único tratamento que não causou toxicidade crônica a $C$. silvestrii, não apresentando diferença significativa em relação ao controle (teste estatístico de Steel Many One Rank).

Em termos de mortalidade, observou-se que, no ensaio com $C$. silvestrii, o valor da CE50 144h foi maior para o afluente do que para o efluente (tabela 6.4). Em termos de reprodução, verificou-se que a menor concentração do efluente que causou efeito crônico a $C$. silvestrii foi de $25 \%$, enquanto que do afluente foi de 50\%. Essa espécie apresentou estimativa de crescimento populacional (r) superior no afluente em relação ao efluente (figura 6.5).

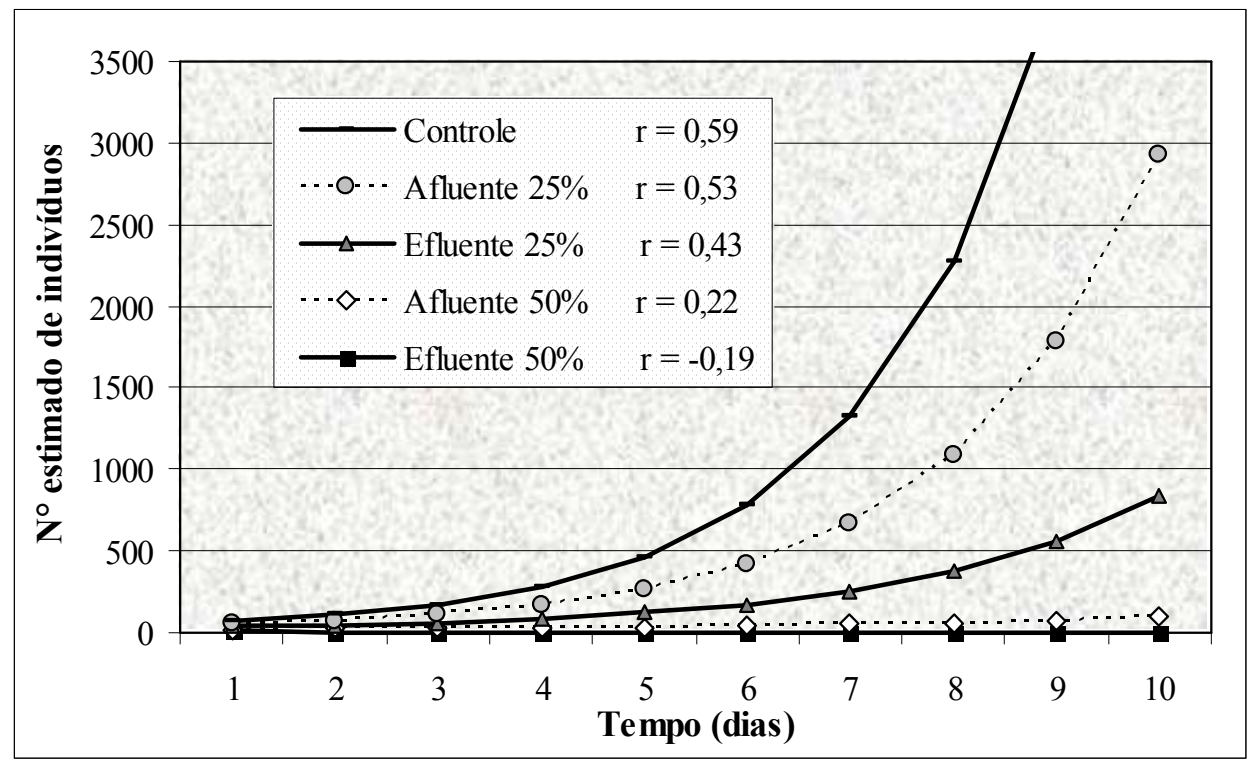

Figura 6.5. Estimativa de crescimento populacional de C. silvestrii exposta ao esgoto.

Cumpre ressaltar que foi observada a presença de um grande número de rotíferos somente nas amostras de efluente. Rotíferos são invertebrados microscópicos (de 0,05 a 2,0mm de comprimento) pertencentes ao super filo dos asquelmintes que se alimentam principalmente de detritos, bactérias e pequenas algas (PARESCHI, 2004). Os rotíferos em geral são bons indicadores 
de poluição orgânica, podendo ocorrer em esgotos com algum teor de oxigênio, como nos sistemas de tratamento biológico aeróbio. Sua presença no efluente de uma ETE indica eficiência no sistema de tratamento de esgotos (NUVOLARI, 2003).

Durante os bioensaios com C. silvestrii, a existência de grande quantidade de rotíferos no efluente pode ter ocasionado competição por recursos ou atrito físico entre os dois organismos, influenciando a maior mortalidade e menor reprodutividade de C. silvestrii nas amostras diluídas de efluente em relação às de afluente. Esse fato pode não ter sido significativo nos bioensaios com amostras integrais do esgoto (afluente e efluente) em função da mortalidade de C. silvestrii ter ocorrido logo nas primeiras 24 horas de exposição ao afluente $100 \%$ concentrado, indicando sua maior toxicidade aguda em relação ao efluente.

Os dados obtidos nesta coleta preliminar demonstram que o desempenho apresentado pela ETE-Araraquara na remoção de matéria orgânica e nutrientes e na promoção da oxigenação do esgoto foi suficiente para influenciar na alta eficiência desse sistema em termos de eliminação de toxicidade para D. rerio, C. xanthus e D. similis. Mesmo assim, deve-se considerar que o esgoto tratado ainda causou toxicidade crônica em C. silvestrii, indicando que substâncias tóxicas ainda devem persistir ao tratamento promovido pela ETE.

Laitano \& Matias (2006), em um estudo de tratamento de lixiviado em reator experimental do tipo UASB, obtiveram $70 \%$ de eficiência em termos de remoção de DQO e $80 \%$ de eficiência em termos de redução de toxicidade para D. magna, sendo ainda verificada a presença de alta toxicidade para amostras do efluente tratado.

Já estudos realizados por Silva et al. (2000) e Magris et al. (2006), que avaliaram a eficiência de ETEs do tipo Lagoas de Estabilização e reatores UASB, respectivamente, observaram baixa eficiência na remoção de toxicidade, mesmo alcançando eficiência satisfatória na remoção de matéria orgânica. Ambos os autores sugeriram que esse resultado pode indicar que as referidas ETEs, além de receberem os despejos líquidos provenientes dos usos domésticos, estão sujeitos a sofrerem o aporte de efluentes de pequenos estabelecimentos comerciais e industriais com características distintas dos efluentes domésticos.

Tomando-se como base a eficiência de tratamento de esgotos da ETE de Araraquara observada neste estudo e o custo médio da energia elétrica empregada nesse tipo de tratamento (em torno de $\mathrm{R} \$ 0,057 \mathrm{o} \mathrm{m}^{3}$ de esgoto tratado, segundo Scalize, 2003), observa-se que o custo-benefício da implementação de sistemas de tratamento de esgotos é altamente positivo, promovendo a mitigação da contaminação orgânica dos corpos hídricos receptores.

Fica claro, portanto, a importância de maiores investimentos na área de saneamento básico no Brasil. A ampliação da infra-estrutura sanitária em estados com precárias condições de saneamento ambiental é um investimento capaz de proporcionar melhoria na qualidade de vida da 
população, na medida em que promove a diminuição de incidência de doenças de veiculação hídrica e internações hospitalares e, conseqüentemente, reduz gastos públicos e particulares com medicina curativa. A implantação de sistemas de tratamento de esgotos ainda ajuda a reduzir despesas com o tratamento de água de abastecimento público por evitar comprometer os recursos hídricos, sendo que, melhorando a qualidade ambiental, a região torna-se mais atrativa para investimentos externos, podendo inclusive desenvolver sua vocação turística.

\subsection{Variabilidade temporal das características físicas, químicas e bacteriológicas do esgoto tratado da ETE-Araraquara}

Neste item serão apresentados e comparados os resultados das análises físicas, químicas e bacteriológicas do esgoto tratado da ETE-Araraquara coletado nas 4 amostragens (15/09/2003, 26/04/2004, 05/07/2004 e 17/11/2004), a fim de analisar a variabilidade do efluente ao longo do tempo.

As características do esgoto são determinadas em função dos usos à qual a água foi submetida. Como os usos da água variam com o clima, com a situação social e econômica e hábitos da população, a quantidade e a qualidade de esgotos gerados em uma dada localidade apresentam variações ao longo do dia (variações horárias), ao longo da semana (variações semanais) e ao longo dos anos (variação sazonal) (VON SPERLING, 2005). A composição e a qualidade dos efluentes líquidos também podem variar ao longo do tempo devido a alterações na eficiência do sistema de tratamento de esgotos.

Neste estudo, foi verificada variação sazonal da grande maioria dos parâmetros físicos, químicos e bacteriológicos analisados para o esgoto tratado na ETE-Araraquara, conforme pode ser observado na tabela 6.5 e figuras A-II.1. a A-II.9. (em anexo).

Durante a coleta do dia 26/04/2004, observou-se a maior vazão do efluente (550L/s), enquanto que a menor vazão foi obtida durante a coleta do dia 05/07/2004. Deve-se observar que no mês de abril de 2004 ocorreu o mais alto índice pluviométrico para a região de Araraquara durante o período estudado (65,8mm), seguido pelos meses de novembro de 2004 (58,9mm), julho de 2004 $(43,9 \mathrm{~mm})$ e setembro de $2003(14,5 \mathrm{~mm})$.

A temperatura do efluente oscilou entre $19,6^{\circ} \mathrm{C}$ e $24,2^{\circ} \mathrm{C}$, sendo que a temperatura mais baixa foi observada no inverno (05/07/2004 ) e a mais alta no verão (17/11/2004). 
Tabela 6.5. Resultados das análises físicas, químicas e bacteriológicas realizadas em amostras de efluente da ETE - Araraquara coletadas em 15/09/03 (1 ${ }^{\text {a }}$ coleta); 26/04/2004 ( $2^{\text {a }}$ coleta); 05/07/2004 ( $3^{\text {a }}$ coleta) e $17 / 11 / 2004$ (4 coleta).

\begin{tabular}{|c|c|c|c|c|c|}
\hline Parâmetros & Unidade & $1^{a}$ Coleta & $2^{a}$ Coleta & $3^{a}$ Coleta & $4^{a}$ Coleta \\
\hline Vazão & $\mathrm{L} / \mathrm{s}$ & 500 & 550 & 4400 & 500 \\
\hline Temperatura & ${ }^{\circ} \mathrm{C}$ & 21,8 & 21,2 & 19,6 & 24,2 \\
\hline pH & & 7,7 & 7,6 & 7,4 & 7,8 \\
\hline Condutividade & $\mu \mathrm{S} / \mathbf{c m}$ & 436 & 613 & 573 & 604 \\
\hline Absorbância 254nm & & - & 0,494 & $\mathbf{0 , 5 7 4}$ & 0,922 \\
\hline Alcalinidade & $\mathrm{mg} / \mathrm{L}$ & - & 174 & 100 & 170 \\
\hline OD & $\mathrm{mg} / \mathrm{L}$ & 8,5 & 7,4 & 7,4 & 7,6 \\
\hline Dureza & $\mathrm{mg} / \mathrm{L}$ & 58 & 52 & 60 & 54 \\
\hline Cloreto & $\mathrm{mg} / \mathrm{L}$ & 41,4 & - & 49,0 & 56,0 \\
\hline Sulfeto & $\mathrm{mg} / \mathrm{L}$ & 0,05 & - & 0,13 & 0,19 \\
\hline Sulfato & $\mathrm{mg} / \mathrm{L}$ & 50 & - & 64 & 52 \\
\hline ST & $\mathrm{mg} / \mathrm{L}$ & 450 & 365 & 377 & 379 \\
\hline STV & $\mathrm{mg} / \mathrm{L}$ & 220 & 104 & 152 & 142 \\
\hline STF & $\mathrm{mg} / \mathrm{L}$ & 230 & 261 & 225 & 237 \\
\hline SST & $\mathrm{mg} / \mathrm{L}$ & 34 & 57 & 101 & 81 \\
\hline SSV & $\mathrm{mg} / \mathrm{L}$ & 30 & 47 & 87 & 63 \\
\hline SSF & $\mathrm{mg} / \mathrm{L}$ & 4,6 & 10,1 & 14,2 & 18,2 \\
\hline SDT & $\mathrm{mg} / \mathrm{L}$ & 416 & 309 & 279 & 286 \\
\hline SDV & $\mathrm{mg} / \mathrm{L}$ & 198 & 170 & 83 & 206 \\
\hline SDF & $\mathrm{mg} / \mathrm{L}$ & 218 & 139 & 196 & 80 \\
\hline NTK & $\mathrm{mg} / \mathrm{L}$ & 14,32 & 27,76 & 23,38 & 12,51 \\
\hline Amônia & $\mathrm{mg} / \mathrm{L}$ & 10,68 & 17,58 & 11,88 & 2,00 \\
\hline Nitrito & $\mathrm{mg} / \mathrm{L}$ & 2,796 & 0,044 & 6,990 & $\mathbf{0 , 0 3 3}$ \\
\hline Nitrato & $\mathrm{mg} / \mathrm{L}$ & 3,272 & 0,518 & 7,590 & 0,088 \\
\hline Fósforo Total & $\mathrm{mg} / \mathrm{L}$ & 6,417 & 3,707 & 4,855 & 6,152 \\
\hline Fosfato total dissolvido & $\mathrm{mg} / \mathrm{L}$ & 5,097 & 3,504 & 4,260 & 2,035 \\
\hline Fosfato inorgânico & $\mathrm{mg} / \mathrm{L}$ & 5,04 & 2,93 & 3,49 & 1,83 \\
\hline Silicato & $\mathrm{mg} / \mathrm{L}$ & 27,50 & 17,80 & 21,20 & 20,10 \\
\hline $\mathbf{P b}$ & $\mathrm{mg} / \mathrm{L}$ & ND & 0,014 & 0,005 & 0,010 \\
\hline $\mathbf{C r}$ & $\mathrm{mg} / \mathrm{L}$ & 0,0225 & 0,036 & 0,025 & $\mathbf{0 , 0 2 9}$ \\
\hline Cd & $\mathrm{mg} / \mathrm{L}$ & ND & ND & ND & ND \\
\hline $\mathbf{C u}$ & $\mathrm{mg} / \mathrm{L}$ & ND & ND & ND & ND \\
\hline Zn & $\mathrm{mg} / \mathrm{L}$ & 0,036 & 0,043 & ND & $\mathbf{0 , 2 3 0}$ \\
\hline Ni & $\mathrm{mg} / \mathrm{L}$ & ND & ND & ND & ND \\
\hline $\mathbf{F e}$ & $\mathrm{mg} / \mathrm{L}$ & 1,976 & 1,837 & 0,672 & 4,240 \\
\hline Mn & $\mathrm{mg} / \mathrm{L}$ & 0,047 & 0,061 & 0,029 & 0,056 \\
\hline $\mathbf{C a}$ & $\mathrm{mg} / \mathrm{L}$ & 9,595 & 8,153 & 5,941 & 5,139 \\
\hline Mg & $\mathrm{mg} / \mathrm{L}$ & 0.906 & 0.909 & 0.809 & 0.908 \\
\hline COT & $\mathrm{mg} / \mathrm{L}$ & 25,2 & 28,9 & 37,9 & 45,1 \\
\hline DQO & $\mathrm{mg} / \mathrm{L}$ & 160 & 167 & 199 & 263 \\
\hline DBO & $\mathrm{mg} / \mathrm{L}$ & 64,4 & 52,8 & 135,8 & 80,2 \\
\hline Coliformes totais & NMP/100ml & $12,59 \times 10^{5}$ & $2,62 \times 10^{5}$ & $26,13 \times 10^{5}$ & $48,84 \times 10^{5}$ \\
\hline E. coli & NMP/100ml & $2,09 \times 10^{5}$ & $0,31 \times 10^{5}$ & $1,89 \times 10^{5}$ & $10,12 \times 10^{5}$ \\
\hline
\end{tabular}

- : Não Determinado

ND: Não Detectado.

Vermelho: abaixo do limite de detecção do equipamento.

Azul: abaixo do limite de quantificação do equipamento. 
As medidas de $\mathrm{pH}$, dureza e oxigênio dissolvido se mantiveram relativamente homogêneas ao longo das diferentes amostragens.

O meio permaneceu básico, variando entre 7,42 e 7,78. A dureza variou entre 60 e $52 \mathrm{mgCaCO}_{3} / \mathrm{L}$ (dureza moderada). A concentração de oxigênio dissolvido oscilou entre $8,5 \mathrm{e}$ $7,6 \mathrm{mg} / \mathrm{L}$. Essa oxigenação do esgoto tratado foi promovida primeiramente pela aeração das águas residuárias nas Lagoas de Aeração e, posteriormente, pelo turbilhonamento do efluente ao longo do canal de lançamento no Ribeirão das Cruzes.

Os valores de condutividade variaram de $436 \mu \mathrm{S} / \mathrm{cm}$ a $613 \mu \mathrm{S} / \mathrm{cm} \quad\left(1^{\mathrm{a}}\right.$ e $2^{\mathrm{a}}$ coletas, respectivamente), sendo observada certa homogeneidade de suas medidas nas amostragens de 26/04/2004 e 17/11/2004.

A concentração de sólidos totais da ETE-Araraquara variou de 365,5mg/L ( $2^{\mathrm{a}}$ coleta) a $450 \mathrm{mg} / \mathrm{L}\left(1^{\mathrm{a}}\right.$ coleta). Em todas as coletas, a concentração de sólidos dissolvidos foi superior à de sólidos em suspensão e a fração de sólidos totais fixos foi superior a de voláteis.

A proporção de sólidos em suspensão voláteis foi superior a de sólidos em suspensão fixos em todas as amostragens. Porém, para os sólidos dissolvidos, a fração fixa foi superior à volátil somente na $1^{\mathrm{a}}$ e $3^{\mathrm{a}}$ coletas, enquanto que nas outras coletas essa proporção foi invertida (figura AII.7). Pode-se considerar que os sólidos voláteis representam uma estimativa da matéria orgânica presente nos sólidos e os sólidos fixos representam a matéria inorgânica ou mineral.

A importância de estudar a fração de sólidos presente no efluente reside no fato de que todos os contaminantes, com exceção dos gases dissolvidos, contribuem para a carga de sólidos nas águas residuárias (VON SPERLING, 2005).

Com relação às formas nitrogenadas, o nitrogênio orgânico e a amônia foram as formas predominantes no esgoto tratado da ETE-Araraquara. Nas duas primeiras coletas a proporção de amônia foi superior à de nitrogênio orgânico, já na $3^{\mathrm{a}}$ coleta houve proporção equivalente entre nitrogênio orgânico e amônia, enquanto que na última coleta essa proporção se inverteu (figura AII.6).

As concentrações de nitrito e nitrato nas amostras de esgoto da $2^{\mathrm{a}}$ e $4^{\mathrm{a}}$ coletas foram insignificantes, enquanto que na $1^{\mathrm{a}}$ e $3^{\mathrm{a}}$ coletas essas formas oxidadas de nitrogênio foram mais significativas.

Observa-se que o nitrogênio presente no esgoto fresco está quase todo combinado sob a forma de proteína e uréia (nitrogênio orgânico). No sistema de tratamento de esgotos, as bactérias, no seu trabalho de oxidação biológica, transformam o nitrogênio presente nas águas residuárias primeiramente em amônia, depois em nitritos, e em seguida em nitratos. A concentração com que o nitrogênio aparece sob essas várias formas indica a idade do esgoto e/ou sua estabilização em 
relação à demanda de oxigênio. Nesse sentido, acredita-se que o processo de nitrificação do esgoto na ETE-Araraquara durante a $1^{\mathrm{a}}$ e $3^{\mathrm{a}}$ coletas foi mais efetivo do que na $2^{\mathrm{a}}$ e na $4^{\mathrm{a}}$ coletas.

Das formas fosfatadas encontradas no esgoto tratado da ETE-Araraquara, o fosfato inorgânico (polifosfatos e ortofosfatos) e dissolvido (ou solúvel) foi predominante nas 3 primeiras coletas, enquanto que na última coleta a proporção do fosfato orgânico e particulado (em suspensão) foi mais significativa (figura A-II.8). O fosfato inorgânico (ortofosfato e polifosfato) é constituinte de vários materiais de limpeza, assim como de fertilizantes. Fosfatos orgânicos são formados primeiramente por processos biológicos, podendo ser encontrados nos esgotos como restos de alimentos e cadáveres. Também podem ser formados por ortofosfatos em processos de tratamento biológico e pela biota do corpo hídrico afluente no esgoto.

As concentrações de silicato nas amostras do efluente tratado variaram de $27,5 \mathrm{mg} / \mathrm{L}$ a $17,8 \mathrm{mg} / \mathrm{L}\left(1^{\mathrm{a}}\right.$ e $2^{\mathrm{a}}$ coletas, respectivamente).

Com relação a alcalinidade, foram obtidos valores entre 100 e $174 \mathrm{mgCaCO}_{3} / \mathrm{L}^{2} 2^{\mathrm{a}}$ e $3^{\mathrm{a}}$ coletas, respectivamente). Considerando que o $\mathrm{pH}$ das amostras variou entre 7,42 e 7,78, o principal constituinte da alcalinidade encontrado no esgoto foi o bicarbonato. Nota-se que a menor concentração de alcalinidade foi obtida durante a coleta onde foi observada maior nitrificação do esgoto, indicando que houve consumo de alcalinidade.

As concentrações de sulfeto e cloreto foram crescentes ao longo do tempo. A amostra de esgoto coletada em 17/11/2004 apresentou concentração de sulfeto cerca de duas vezes maior do que a amostra coletada em $15 / 09 / 2003\left(0,188 \mathrm{mg} / \mathrm{L}\right.$ na $4^{\text {a }}$ coleta a $0,05 \mathrm{mg} / \mathrm{L}$ na $1^{\text {a }}$ coleta $)$. A presença de sulfetos nos esgotos provêm principalmente da redução bacteriana do sulfato, porém uma fração pode ter origem da decomposição da matéria orgânica (algumas vezes oriundas de despejos industriais). As concentrações de sulfato foram maiores na $3^{\text {a }}$ coleta $(64 \mathrm{mg} / \mathrm{L})$ e equivalentes nas duas outras amostragens.

Quanto à concentração de matéria orgânica presente no esgoto, as medidas de COT e DQO tenderam a aumentar ao longo do tempo. As menores concentrações de COT e DQO foram obtidas na $1^{\mathrm{a}}$ coleta $(25,2 \mathrm{mgCOT} / \mathrm{L}$ e $160 \mathrm{mgDQO} / \mathrm{L})$, enquanto que as maiores medidas foram verificadas na $4^{\mathrm{a}}$ coleta $(45,1 \mathrm{mgCOT} / \mathrm{L}$ e $263 \mathrm{mgDQO} / \mathrm{L})$.

As medidas de absorbância a $254 \mathrm{~nm}$ das amostras seguiu o mesmo padrão de crescimento ao longo do tempo, variando de 0,494 em 26/04/2004 a 0,922 em 17/11/2004. Esse resultado é justificado pelo fato da absorbância estar diretamente relacionada com a concentração de matéria orgânica e sólidos em suspensão do efluente.

Já as medidas de DBO oscilaram entre 52,78 e $135,85 \mathrm{mg} / \mathrm{L} \quad\left(2^{\mathrm{a}}\right.$ e $3^{\mathrm{a}}$ coletas, respectivamente), sendo que seu maior valor foi encontrado quando foi observada maior nitrificação do esgoto. 
A maior relação DQO/DBO encontrada neste estudo foi durante a $4^{\mathrm{a}}$ coleta $(3,28)$ e a menor foi durante a $3^{\mathrm{a}}$ coleta $(1,46)$.

Com relação aos coliformes totais e $E$. coli, as menores concentrações foram obtidas na $2^{\mathrm{a}}$ coleta $\left(2,62 \times 10^{5}\right.$ e $\left.3,1 \times 10^{4} \mathrm{NMP} / 100 \mathrm{~mL}\right)$ e as maiores foram obtidas na $4^{\mathrm{a}}$ coleta $\left(4,88 \times 10^{6} \mathrm{e}\right.$ $\left.1,01 \times 10^{6} \mathrm{NMP} / 100 \mathrm{~mL}\right)$.

As concentrações dos metais chumbo, cromo, cádmio, cobre e níquel se mantiveram sempre abaixo do limite de quantificação do equipamento utilizado para sua análise. O mesmo foi verificado para o zinco durante as 3 primeiras coletas, indicando que não houve input desses metais no esgoto sanitário da ETE-Araraquara no período estudado.

Quanto ao ferro e manganês, suas maiores concentrações foram observadas durante a $4^{\mathrm{a}}$ coleta $(4,24 \mathrm{mgFe} / \mathrm{L}$ e $0,056 \mathrm{mgMn} / \mathrm{L})$ e suas menores medidas foram obtidas durante a $3^{\mathrm{a}}$ coleta $(0,672 \mathrm{mgFe} / \mathrm{L}$ e $\quad 0,029 \mathrm{mgMn} / \mathrm{L})$. Já o cálcio teve sua maior concentração durante a $1^{\mathrm{a}}$ coleta $(9,5$ $\mathrm{mgCa} / \mathrm{L})$ e sua menor medida durante a $4^{\mathrm{a}}$ coleta $(5,13 \mathrm{mgCa} / \mathrm{L})$, enquanto que a concentração de magnésio permaneceu estável durante o período amostral.

De uma maneira geral, as concentrações dos parâmetros físicos, químicos e bacteriológicos analisados neste estudo, encontram-se dentro dos limites estabelecidos pelas Resoluções do CONAMA (N 20/86 e N 357/2005) e pelo Decreto Estadual № 8.468/76 para corpos d'água de classe 4. No entanto, a concentração de amônia presente no efluente extrapolou o padrão de lançamento determinado pelo Decreto Estadual $\mathrm{N}^{\circ} 8.468 / 76(5 \mathrm{mg} / \mathrm{L})$ nas amostragens de 15/09/2003, 26/04/2004 e 05/07/2004. O mesmo ocorreu para os valores de $\mathrm{DBO}_{5}$ nas amostras coletadas em 15/09/2003, 05/07/2004 e 17/11/2004, já que o limite máximo de lançamento, que é de $60 \mathrm{mg} / \mathrm{L}$, foi ultrapassado.

É importante lembrar que, segundo informações do Departamento Autônomo de Água e Esgotos (DAAE) de Araraquara, a eficiência do sistema de tratamento de esgotos de Araraquara ficou prejudicada pela quebra de alguns aeradores responsáveis pelo tratamento secundário da ETE durante o período amostral do presente estudo.

A composição do esgoto sanitário de Araraquara certamente não se restringe apenas aos parâmetros ora analisados.

Araújo (2006), por exemplo, estudou a concentração de hormônios sexuais presentes no esgoto bruto e tratado da ETE-Araraquara, os quais são excretados pela urina de mamíferos. A autora identificou a presença de um hormônio natural (E2) somente no esgoto bruto, indicando que a ETE-Araraquara foi eficiente na remoção desse analito.

Da mesma maneira, Peron (2007) constatou a presença de fármacos (diclofenaco sódico) nas amostras do efluente doméstico da cidade de Araraquara-SP antes e após o tratamento, nas concentrações de 18,0 e $22,0 \mu \mathrm{g} / \mathrm{L}$, respectivamente. 
Portanto, em misturas heterogêneas e complexas, como é o caso do esgoto sanitário, há uma série de compostos orgânicos e inorgânicos potencialmente poluidores que são de difícil determinação laboratorial.

Nesses casos, torna-se mais vantajoso avaliar o potencial tóxico do esgoto sanitário, através de bioensaios, do que identificar e quantificar as espécies individuais de compostos presentes no efluente, através de análises químicas.

\subsubsection{Avaliação ecotoxicológica do esgoto tratado da ETE-Araraquara}

Com relação ao potencial tóxico das amostras de esgoto tratado da ETE-Araraquara coletadas em 15/9/2003, 26/04/2004, 05/07/2004 e 17/11/2004, a variabilidade das características químicas, físicas e bacteriológicas do efluente também ocasionou alterações da sua toxicidade, evidenciadas por meio dos bioensaios com D. similis, D. rerio, C. xanthus, C. silvestrii e A. cepa.

Analisando a tabela 6.6, pode-se observar que o esgoto de Araraquara provocou efeitos deletérios aos organismos-teste em todas as coletas, porém, em diferentes níveis.

A amostra de esgoto coletada em 26/04/2004 (2a coleta) se mostrou tóxica a três organismos-teste distintos (C. silvestrii, D. rerio e A. cepa). Já o efluente coletado em 05/07/2004 foi significativamente diferente do controle apenas no bioensaio com $C$. silvestrii, porém, também foi observado indício de toxicidade para A. cepa. Para a amostra coletada em 17/11/2004, foi verificada toxicidade aguda para $C$. silvestrii e indícios de toxicidade para $D$. rerio; enquanto que na coleta do dia 15/09/2003, apenas C. silvestrii sofreu efeitos deletérios (indícios de toxicidade aguda para as primeiras $48 \mathrm{~h}$ de exposição e toxicidade crônica para $168 \mathrm{~h}$ de exposição, conforme pode ser observado no item 6.1.1 deste estudo). 
Tabela 6.6. Resultados dos testes de toxicidade com amostras de esgoto tratado da ETE - Araraquara coletadas em 15/09/03 ( $1^{\text {a }}$ coleta); 26/04/2004 ( $2^{\text {a }}$ coleta); 05/07/2004 ( $3^{\text {a }}$ coleta) e 17/11/2004 ( $4^{\text {a }}$ coleta).

\begin{tabular}{|c|c|c|c|c|c|c|}
\hline \multirow{2}{*}{$\begin{array}{l}\text { Organismos- } \\
\text { teste }\end{array}$} & \multirow{2}{*}{$\begin{array}{c}\text { Efeito } \\
\text { observado } \\
\text { (\%) }\end{array}$} & \multirow{2}{*}{$\begin{array}{c}\text { Período de } \\
\text { exposiçãa (h) }\end{array}$} & \multicolumn{4}{|c|}{ Amostras } \\
\hline & & & $\begin{array}{l}\text { Efluente } \\
1^{\mathrm{a}} \text { coleta }\end{array}$ & $\begin{array}{l}\text { Efluente } \\
2^{\text {a }} \text { coleta }\end{array}$ & $\begin{array}{l}\text { Efluente } \\
\mathbf{3}^{\mathbf{a}} \text { coleta }\end{array}$ & $\begin{array}{l}\text { Efluente } \\
4^{\text {a }} \text { coleta }\end{array}$ \\
\hline D. similis & Imobilidade & 48 & 0 & 0 & 0 & 0 \\
\hline D. rerio & Mortalidade & 96 & 0 & $26,6(\mathrm{~T})$ & 0 & 20 (IT) \\
\hline C. xanthus & Mortalidade & 168 & 10 & 0 & 0 & 10 \\
\hline C. silvestrii & Imobilidade & 48 & 20 (IT) & $50(\mathrm{~T})$ & $100(\mathrm{~T})$ & $60(\mathrm{~T})$ \\
\hline A. сера & $\begin{array}{l}\text { Inibição de } \\
\text { Crescimento }\end{array}$ & 72 & - & $44,12(\mathrm{~T})$ & 27,33 (IT) & $-16,9$ \\
\hline
\end{tabular}

*Inibição do crescimento da raiz da cebola (porcentagem em relação ao controle).

Valores em vermelho correspondem a amostras significativamente diferentes do controle (teste de Dunnett para $A$. cepa e de Steel Many One Rank para os outros organismos); isto é, tóxicas.

Valores em azul correspondem a amostras onde houve indícios de toxicidade.

Logo, pode-se considerar que a amostra de esgoto mais tóxica foi a coletada em 26/04/2004, sendo seguida pelas amostras de 5/7/2004 e 17/11/2004 e, por último, pela amostra de 15/09/03.

Observa-se, portanto, que o tratamento promovido pela ETE-Araraquara, durante o período do estudo, não conseguiu remover todos os toxicantes presentes no esgoto sanitário oriundo da cidade de Araraquara e que esse efluente deve estar contribuindo para a degradação do corpo hídrico receptor.

Deve-se ressaltar, no entanto, que se o esgoto sanitário fosse lançado in natura no Ribeirão das Cruzes, certamente haveria um prejuízo significativamente maior para a biota local, tomando como base os resultados dos testes de toxicidade com amostras de esgoto bruto (afluente) já apresentados no item 6.1.1 deste estudo.

Os resultados dos bioensaios ora apresentados demonstram claramente que cada espécie apresenta sensibilidades e tolerâncias específicas a diferentes agentes tóxicos. Os organismos-teste, quando expostos ao esgoto sanitário, entram em contato com inúmeras substâncias simultaneamente, as quais podem sofrer interações de sinergismo, aditivismo e antagonismo, alterando o potencial tóxico individual de cada uma delas. Sendo assim, é natural que os organismos respondam de forma diversa quando submetidas às mesmas amostras de efluente.

Neste estudo, $C$. silvestrii foi o organismo-teste mais sensível, apresentando toxicidade em todas as amostras analisadas. É importante lembrar que os bioensaios com C. silvestrii foram originalmente desenhados para ocorrerem em um período de 7 dias (teste crônico), porém, como na grande maioria dos experimentos (com exceção dos realizados com amostras da $1^{\text {a }}$ coleta), os organismos não sobreviveram após 96 horas de exposição, optou-se por apresentar os resultados obtidos no período de 48 horas de testes. 
Sendo assim, considerando somente as primeiras 48 horas de teste, observa-se que o efluente da $1^{\mathrm{a}}$ coleta foi menos tóxico do que o das outras amostragens, sendo que na $3^{\mathrm{a}}$ coleta foi obtido o maior efeito deletério agudo a C. silvestrii (100\% de mortalidade).

É importante lembrar que foi observada a presença de um grande número de rotíferos em todas as amostras de efluente, o que pode ter ocasionado competição por recursos e influenciando na maior mortalidade de C. silvestrii ao longo dos bioensaios. Deve-se considerar também a hipótese de entupimento do aparelho filtrador desse organismo, em função das altas concentrações de sólidos em suspensão no esgoto, que pode ter causado sua morte.

Já os organismos-teste D. similis e C. xanthus se mostraram mais resistentes quando expostos a amostras de esgoto, não sofrendo efeito tóxico (mortalidade) em nenhuma das coletas.

Considerando que $C$. xanthus freqüentemente representa a porção mais significativa da biomassa bentônica de ambientes de água doce (GIESY et al. 1988; LUCCA, 2006), a extrapolação dos resultados dos bioensaios neste estudo pode sugerir que o esgoto tratado da ETE-Araraquara não acarreta maiores prejuízos à comunidade bentônica do corpo hídrico receptor. Deve-se observar que a concentração de oxigênio dissolvido ao longo dos testes sofreu um déficit considerável (de 8,5 a $3,0 \mathrm{mg} / \mathrm{L}$ na $1^{\mathrm{a}}$ coleta; 6,8 a $3,4 \mathrm{mg} / \mathrm{L}$ na $3^{\mathrm{a}}$ coleta e 5,6 a $4,2 \mathrm{mg} / \mathrm{L}$ na $4^{\mathrm{a}}$ coleta), o que não provocou efeito deletério ao C. xanthus, uma vez que esse organismo tolera baixas quantidades de oxigênio (CRANSTON, 1995).

Para D. rerio, somente foi verificada diferença significativa entre o controle e a amostra de efluente coletada em 26/04/2004, indicando toxicidade aguda nesse período. Também foi observada $20 \%$ de mortalidade dos organismos-teste expostos à amostra do efluente em 17/11/2004, o que não representa diferença estatística em relação ao controle, mas indica que a amostra provocou um certo grau de efeito deletério ao $D$. rerio.

Já para A. сеpa, foi verificada toxicidade apenas para a amostra de esgoto coletada em 26/04/2004. A amostra de 05/07/2004 provocou inibição no crescimento da raiz da cebola da ordem de $27 \%$, o que, independentemente de comprovação estatística, é um indicativo de toxicidade. Em 17/11/2004, a raiz da cebola, quando exposta à amostra de esgoto, acabou se desenvolvendo melhor do que no controle, sugerindo que a constituição do esgoto naquela ocasião proporcionou alimento e não toxicidade à esse organismo.

Deve-se observar que houve decréscimo dos valores de $\mathrm{pH}$ e oxigênio dissolvido ao longo de todos os testes com $A$. cepa (na $2^{\text {a }}$ coleta: de $\mathrm{pH} 7,6$ a $6,7 \mathrm{mg} / \mathrm{L} \mathrm{e} 6,0$ a $0,8 \mathrm{mg} \mathrm{O}_{2} / \mathrm{L}$; na $3^{\mathrm{a}}$ coleta:

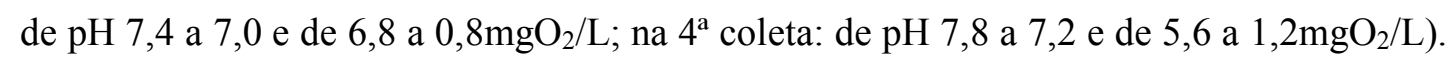

De acordo com Ferreira (2000), a cebola desenvolve-se melhor em ambientes ricos em matéria orgânica, em condições de pH (em água) de 6,0 a 6,5 e com quantidades específicas de nitrogênio e potássio. $\mathrm{O}$ excesso desses nutrientes, pode provocar desequilíbrios na cultura. Nota-se 
que as maiores concentrações de NTK foram observadas em 26/04/2004 e 05/07/2004, quando verificou-se toxicidade ou indício de toxicidade das amostras. No efluente coletado em 17/11/2004, observou-se a menor concentração de NTK e maior carga orgânica (COT, DQO) do estudo, o que pode ter contribuído para o melhor desenvolvimento das raízes da cebola.

Apesar das várias hipóteses que possam ser levantadas com relação às causas da toxicidade do esgoto, em geral não é possível estabelecer correlação entre a constituição física e química dos efluentes e sua toxicidade, uma vez que os resultados dos bioensaios expressam um efeito produzido em função das interações das substâncias nas amostras, as quais se mostram bastante complexas e heterogêneas (JARDIM, 2004).

Nota-se, no entanto, que houve variabilidade sazonal do potencial tóxico do esgoto tratado da ETE-Araraquara da mesma forma como ocorreu com sua composição física, química e bacteriológica.

\subsection{Ensaios de desinfecção}

Os dados obtidos nos diferentes ensaios de desinfecção com amostras de esgoto sanitário proveniente da ETE-Araraquara coletadas em 26/04/2004 ( $2^{\text {a }}$ coleta), 05/07/2004 ( $3^{\text {a }}$ coleta) e 17/11/2004 (4 ${ }^{\mathrm{a}}$ coleta) serão apresentados a seguir.

Cabe ressaltar que nas coletas efetuadas em abril e julho de 2004, os ensaios de desinfecção foram realizados apenas com PAA e radiação UV; enquanto que na amostragem de novembro de 2004, foram utilizados nos ensaios de desinfecção o PAA, a radiação UV, o Cloro e o Ozônio.

\subsubsection{Desinfeç̧ão com Ácido Peracético}

Neste estudo, foram realizadas três baterias de ensaios de desinfecção com ácido peracético (PAA), conforme descrito na tabela 6.7. Em cada bateria foram conduzidos experimentos com concentrações de PAA e tempos de contatos diferentes, sendo utilizadas amostras de efluente coletadas nas datas específicas. 
Tabela 6.7. Características dos ensaios de desinfecção de amostras de esgoto da ETE-Araraquara empregando ácido peracético.

\begin{tabular}{|ccccc|}
\hline Bateria & $\begin{array}{c}\text { Data de coleta do } \\
\text { efluente }\end{array}$ & Ensaios & $\begin{array}{c}\text { Concentração } \\
\text { (mg/L) }\end{array}$ & $\begin{array}{c}\text { Tempo de Contato } \\
\text { (min) }\end{array}$ \\
\hline \hline $1^{\mathrm{a}}$ & $26 / 4 / 2004$ & 1 & 5 & 40 \\
$1^{\mathrm{a}}$ & $26 / 4 / 2004$ & 2 & 10 & 20 \\
$1^{\mathrm{a}}$ & $26 / 4 / 2004$ & 3 & 10 & 40 \\
\hline \hline $2^{\mathrm{a}}$ & $5 / 7 / 2004$ & 1 & 5 & 20 \\
$2^{\mathrm{a}}$ & $5 / 7 / 2004$ & 2 & 5 & 40 \\
$2^{\mathrm{a}}$ & $5 / 7 / 2004$ & 3 & 10 & 20 \\
$2^{\mathrm{a}}$ & $5 / 7 / 2004$ & 4 & 10 & 40 \\
\hline \hline $3^{\mathrm{a}}$ & $17 / 11 / 2004$ & 1 & 5 & 20 \\
\hline
\end{tabular}

$\mathrm{Na} 1^{\mathrm{a}}$ bateria, foram executados 3 ensaios de desinfecção com o efluente coletado em 26/04/2004. No primeiro ensaio, foi aplicada a concentração de 5mg/L de PAA durante 40 minutos; enquanto que no segundo e terceiro ensaios, a concentração aplicada foi de $10 \mathrm{mg} / \mathrm{L}$ de PAA, porém os tempos de contato (TC) foram de 20 e 40 minutos, respectivamente. Os resultados das análises e exames bacteriológicos da primeira bateria são apresentados na tabela 6.8 .

Tabela 6.8. Resultados dos ensaios de desinfecção com amostras de esgoto da ETE-Araraquara coletadas em 26/04/2004 utilizando ácido peracético ( $1^{\mathrm{a}}$ bateria).

\begin{tabular}{|lcccc|}
\hline \multicolumn{1}{|c}{ Variáveis } & \multicolumn{3}{c|}{ Ácido Peracético } & Efluente \\
\hline \hline Concentração (mg/L) & $\mathbf{5}$ & $\mathbf{1 0}$ & $\mathbf{1 0}$ & - \\
Tempo de Contato (min.) & $\mathbf{4 0}$ & $\mathbf{2 0}$ & $\mathbf{4 0}$ & - \\
\hline Residual (mg/L) & 0,9226 & 0,9525 & 0,9898 & \\
Colif. Totais (NMP/100mL) & 2419,2 & $>2419,2$ & $>2419,2$ & $2,62 \times 10^{5}$ \\
E. coli $(\mathrm{NMP} / 100 \mathrm{~mL})$ & 58,3 & 6,3 & 7,3 & $3,1 \times 10^{4}$ \\
Eficiência inativação E. coli $(\%)$ & 99,812 & 99,980 & 99,976 & - \\
DQO (mg/L) & 147,00 & 134,00 & 166,00 & 167,00 \\
ST (mg/L) & 390,50 & 390,00 & 364,50 & 365,50 \\
SST (mg/L) & 52,53 & 61,96 & 52,83 & 56,73 \\
SDT (mg/L) & 343,00 & 331,00 & 323,00 & 309,00 \\
Alcalinidade (mg/L) & 165,00 & 174,25 & 176,50 & 174,00 \\
pH & 7,63 & 7,39 & 7,46 & 7,61 \\
\hline
\end{tabular}

$\mathrm{Na} 2^{\mathrm{a}}$ bateria de testes, a amostra de efluente coletada em 05/07/2004 foi submetida a 4 ensaios de desinfecção com PAA. No primeiro e segundo ensaios, a concentração aplicada foi de $5 \mathrm{mg} / \mathrm{L}$ de PAA com tempos de contato (TC) de 20 e 40 minutos, respectivamente. Já no terceiro e quarto ensaios, foi usada a concentração de $10 \mathrm{mg} / \mathrm{L}$ de PAA e os TCs foram de 20 e 40 minutos, respectivamente. Os resultados das análises e exames bacteriológicos dessa segunda bateria de ensaios de desinfecção são apresentados na tabela 6.9 . 
Tabela 6.9. Resultados dos ensaios de desinfecção com amostras de esgoto da ETE-Araraquara coletadas em 05/07/2004 utilizando ácido peracético ( $2^{\mathrm{a}}$ bateria).

\begin{tabular}{|c|c|c|c|c|c|}
\hline Variáveis & \multicolumn{4}{|c|}{ Ácido Peracético } & Efluente \\
\hline Concentração (mg/L) & 5 & 5 & 10 & 10 & - \\
\hline Tempo de Contato (min.) & 20 & 40 & 20 & 40 & - \\
\hline Residual (mg/L) & 0,8667 & 0,904 & 0,8443 & 0,9823 & - \\
\hline Colif. Totais (NMP/100mL) & $>4838,4$ & $>4838,4$ & $>4838,4$ & $>4838,4$ & $2,613 \times 10^{6}$ \\
\hline E. coli $(\mathrm{NMP} / 100 \mathrm{~mL})$ & 187,2 & 267,4 & 2,0 & 449,4 & $1,89 \times 10^{5}$ \\
\hline Eficiência inativação E. coli $(\%)$ & 99,901 & 99,859 & 99,999 & 99,762 & - \\
\hline DQO (mg/L) & 220,00 & 223,00 & 240,00 & 228,00 & 199,00 \\
\hline $\mathrm{ST}(\mathrm{mg} / \mathrm{L})$ & 366,50 & 366,00 & 322,50 & 327,00 & 377,00 \\
\hline $\mathrm{SST}(\mathrm{mg} / \mathrm{L})$ & 93,54 & 77,50 & 90,37 & 83,70 & 101,33 \\
\hline $\mathrm{SDT}(\mathrm{mg} / \mathrm{L})$ & 284,00 & 303,00 & 230,00 & 238,00 & 279,00 \\
\hline Alcalinidade $(\mathrm{mg} / \mathrm{L})$ & 101,00 & 108,00 & 101,75 & 108,25 & 100,00 \\
\hline $\mathrm{pH}$ & 7,38 & 7,34 & 7,26 & 7,26 & 7,42 \\
\hline
\end{tabular}

$\mathrm{Na} 3^{\mathrm{a}}$ bateria de testes, foi realizado apenas 1 ensaio de desinfecção com o efluente coletado na última amostragem (17/11/2004), sendo a concentração aplicada de 5mg/L e o TC de 20 minutos. Os resultados das análises e exames bacteriológicos dessa última bateria são apresentados na tabela 6.10 .

Analisando as tabelas 6.7 a 6.9 e a figura 6.6, verifica-se que o efeito do PAA na inativação de E. coli, para todas as concentrações e tempos de contato testadas, esteve entre $99,8119 \%(2,73$ $\log )$ e $99,9989 \%(4,98 \log )$.

A menor eficiência de inativação foi verificada na $1^{\text {a }}$ bateria de testes, no tratamento de 5mgPAA/L e TC de 40 minutos. Ao passo que a maior eficiência encontrada foi para a concentração de $10 \mathrm{mg} / \mathrm{L}$ e 20 minutos, na $2^{\mathrm{a}}$ bateria de ensaios.

Em termos gerais, pode-se considerar que a maior concentração testada $(10 \mathrm{mg} / \mathrm{L})$ provocou melhores resultados na inativação de E. coli. Porém, deve-se ressaltar que na última bateria de testes, a concentração de 5mg/L e 20 minutos de TC obteve eficiência de 4,08 log (99,9917\%), o que representou a segunda melhor eficiência dos ensaios com PAA. 
Tabela 6.10. Resultados dos ensaios de desinfecção com amostras de esgoto da ETE-Araraquara coletadas em 17/11/2004 utilizando ácido peracético ( $3^{\mathrm{a}}$ bateria).

\begin{tabular}{|lcc|}
\hline \multicolumn{1}{|c}{ Variáveis } & Ácido Peracético & Efluente \\
\hline \hline Concentração (mg/L) & $\mathbf{5}$ & - \\
Tempo de Contato (min.) & $\mathbf{2 0}$ & - \\
\hline \hline Residual (mg/L) & 0,82568 & - \\
Colif. Totais (NMP/100mL) & 24192 & $4,884 \times 10^{6}$ \\
E. coli $(\mathrm{NMP} / 100 \mathrm{~mL})$ & 84 & $1,012 \times 10^{6}$ \\
Eficiência inativação E. coli $(\%)$ & 99,9917 & - \\
DQO (mg/L) & 174,00 & 263,00 \\
ST (mg/L) & 357,00 & 379,00 \\
SST (mg/L) & 62,07 & 81,17 \\
SDT (mg/L) & 316,00 & 286,00 \\
Alcalinidade (mg/L) & 167,50 & 170,00 \\
pH & 7,65 & 7,78 \\
\hline
\end{tabular}

Para os ensaios realizados na $1^{\mathrm{a}}$ bateria, o tempo de contato parece não ter influenciado na eficiência de inativação da bactéria. Porém, na $2^{\text {a }}$ bateria, observou-se que os tratamentos com maiores tempos de contato foram menos eficientes em termos de inativação de E. coli.

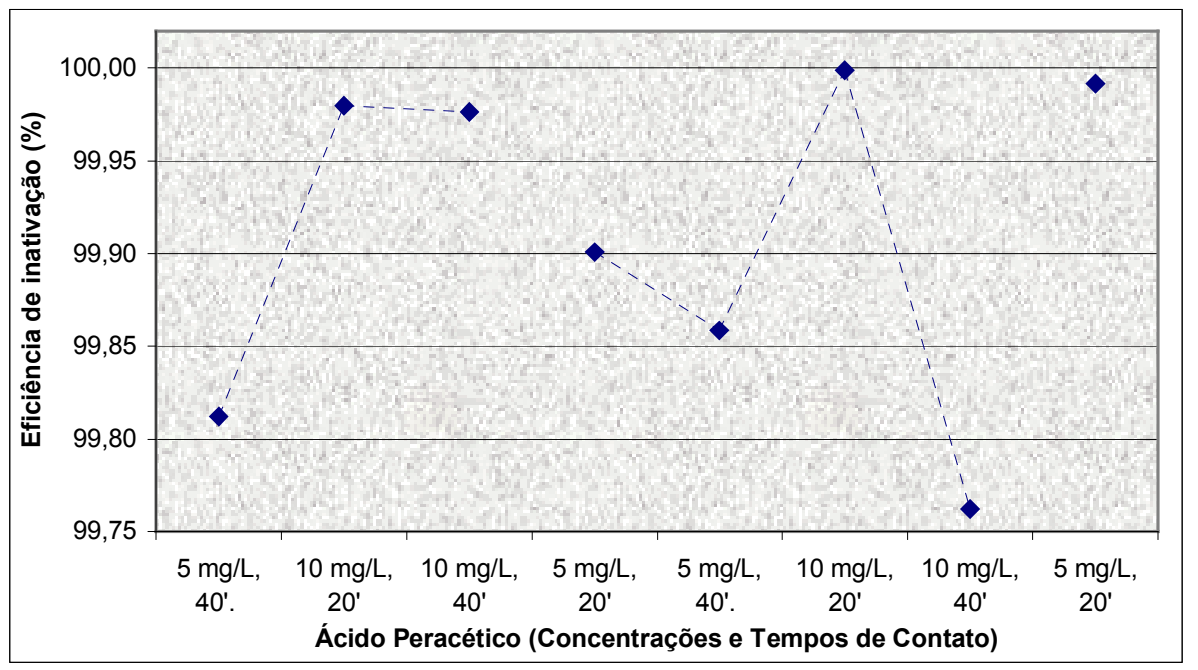

Figura 6.6. Porcentagem de inativação de E. coli em amostras de esgoto da ETE-Araraquara submetidas a desinfecção com PAA em diversas concentrações e tempos de contato. (Obs.: Os pontos interligados representam ensaios realizados na mesma bateria, isto é com efluentes da mesma coleta).

Era de se esperar que a concentração de E. coli decrescesse com o aumento da concentração de ácido peracético e do tempo de contato. Porém, acredita-se que a composição heterogênea do esgoto sanitário e a homogeneização do desinfetante na mistura possam ter interferido no resultado deste estudo, ocasionando menor eficiência para concentrações e tempos de contato maiores. 
Com relação ao residual de ácido peracético, observou-se que, em geral, os tratamentos que obtiveram menor eficiência em termos de inativação de E. coli apresentaram as maiores concentrações de ácido peracético residual, conforme pode ser observado na figura 6.7.

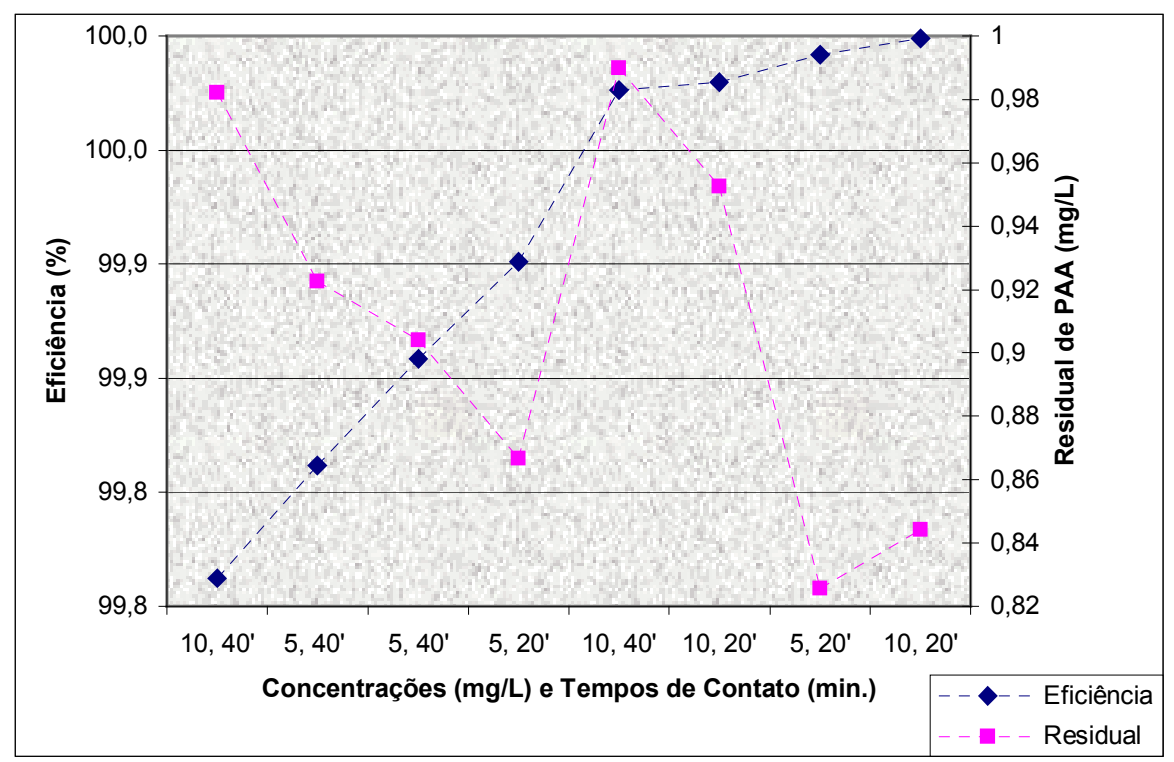

Figura 6.7. Relação entre a concentração de ácido peracético residual $(\mathrm{mg} / \mathrm{L})$ e eficiência de inativação de $E$. coli (\%), obtidas para os diversos ensaios de desinfecção com ácido peracético.

Notou-se também que a demanda de ácido peracético foi aumentando ao longo das coletas do efluente. Isso pode ser explicado pela deterioração da qualidade do esgoto nas diferentes amostragens, evidenciada pelo aumento das concentrações de DQO, COT, sólidos, coliformes totais e E. coli.

Sartori (2004) também analisou o efeito do ácido peracético na inativação de $E$. coli em amostras do esgoto sanitário proveniente da ETE-Araraquara. A autora utilizou concentrações de 5, 10 e $15 \mathrm{mg} / \mathrm{L}$ de PPA e tempos de contato de 10, 20 e 30 minutos. Nos seus ensaios, foram encontrados níveis de inativação da bactéria que variaram de 99,58 (para a menor concentração e tempo de contato) a 99,999 (para concentração de 10 e $15 \mathrm{mg} / \mathrm{L}$ e tempos de contato a partir de 20 minutos). No referido estudo, foi verificada uma certa linearidade na inativação de E. coli em relação às concentrações aplicadas e tempos de contato utilizados, o que não foi observado neste estudo.

As concentrações de ácido peracético residuais obtidas pela autora (média de $0,27 \mathrm{mg} / \mathrm{L}$ para $5 \mathrm{mg} / \mathrm{L}$ de PAA e de 0,19 para a concentração de $10 \mathrm{mg} / \mathrm{L}$ ) foram bastante inferiores às encontradas no presente trabalho (média de 0,87 para $5 \mathrm{mg} / \mathrm{L}$ de PAA e de 0,94 para $10 \mathrm{mg} / \mathrm{L}$ de PAA). 
Por outro lado, Souza (2006), em seu estudo de desinfecção de água reconstituída, verificou concentrações ainda elevadas de PAA residuais ao final dos ensaios. Para água com cor elevada $(\mathrm{COT}=14,53 \mathrm{mg} / \mathrm{L})$, desinfetada com $5 \mathrm{mg} / \mathrm{L}$ de PAA durante 20 minutos, foi verificado residual de $2,37 \mathrm{mg} / \mathrm{L}$.

A eficiência de um desinfetante pode ser afetada por diversos fatores, sejam eles inerentes ao próprio agente desinfetante (tempo de contato, concentração, propriedades físicas e químicas do desinfetante), ou relacionadas com a qualidade do efluente a ser desinfetado (temperatura, $\mathrm{pH}$, alcalinidade, concentração de matéria orgânica, presença de sólidos em suspensão) ou ainda devido a sua interação com o patógeno e a natureza do microorganismo patogênico.

Neste estudo, os tratamentos com ácido peracético não provocaram grandes alterações nos valores de $\mathrm{pH}$ do esgoto, que variaram, no máximo, 0,22 unidades (para os ensaios da $1^{\mathrm{a}}$ bateria) e permaneceram sempre próximos à neutralidade. Esse resultado é compatível com o de outros estudos que utilizaram PAA como desinfetante (BALDRY et al., 1995; SARTORI, 2004; SOUZA, 2006).

Com relação à DQO, observou-se na $1^{\mathrm{a}}$ bateria de testes que houve uma pequena redução da sua medida (de 33mg/L, no máximo) após a desinfecção do esgoto. Essa redução foi maior para o ensaio da $3^{\text {a }}$ bateria (de $89 \mathrm{mg} / \mathrm{L}$ ). A diminuição da DQO indica que uma certa quantidade do agente desinfetante (oxidante) transferida para o efluente pode ter sido consumida por matéria orgânica ou mesmo inorgânica presente no esgoto (reações de oxi-redução), reduzindo assim sua disponibilidade para a inativação dos microorganismos. Baldry et al. (op. cit.) também obteve um pequeno decréscimo de DQO (da ordem de 10mg/L) em seus ensaios de desinfecção com PAA.

De forma inversa, na $2^{\text {a }}$ bateria houve aumento de até $41 \mathrm{mg} / \mathrm{L}$ da DQO do esgoto após a desinfecção. Sartori (op. cit.) também verificou esse comportamento nas amostras de esgoto da ETE-Araraquara desinfetadas com PAA nas mesmas concentrações aqui testadas, inclusive com valores semelhantes de acréscimo de DQO. Kitis (2003) afirma que o aumento do conteúdo orgânico do efluente após desinfecção com PAA ocorre devido ao ácido acético que, além de já estar presente na constituição da solução do ácido peracético (até 16\%) também é formado após a decomposição do produto, o que é indesejável para um agente desinfetante.

Com relação a concentração de sólidos em suspensão, notou-se diminuição de suas medidas no efluente após todos os ensaios de desinfecção. Esse efeito pode ser justificado da mesma forma que a redução de DQO nos tratamentos.

A alcalinidade do esgoto não sofreu grandes alterações após a desinfecção com os diferentes tratamentos, o que pode indicar que os processos oxidativos promovidos pelo agente desinfetante não foram suficientes para consumir a alcalinidade das amostras. 
De uma maneira geral, apenas com uma exceção, observou-se que os diferentes tratamentos foram mais eficientes quanto maior era a concentração de coliformes totais, E. coli, DQO e sólidos totais no esgoto, o que ocorreu gradativamente ao longo das coletas. Alguns autores (SOBSEY, 1989) já haviam verificado que a presença de matéria orgânica e sólidos, até um certo nível, não afetam a eficiência de desinfecção do PAA.

\subsubsection{Desinfecção com Radiação ultravioleta}

Esse tópico será subdividido em duas etapas a fim de facilitar a compreensão dos eventos. Na primeira etapa, serão descritos os resultados dos ensaios para determinação da intensidade média de radiação ultravioleta incidente na superfície irradiada no interior da câmara de desinfecção. Na segunda etapa serão apresentados os resultados dos ensaios de desinfecção propriamente ditos.

\subsubsection{Ensaio para a determinação da intensidade média de radiação UV incidente}

A intensidade média $\left(\mathrm{I}_{0}\right)$ de radiação ultravioleta em $254 \mathrm{~nm}$ incidente na superfície irradiada no interior da câmara de desinfecção para 6 lâmpadas ligadas foi determinada por actinometria, utilizando uma solução de ferrioxalatao de potássio 0,006M.

É importante mencionar que os ensaios actinométricos foram conduzidos com a lâmina líquida fixada em $1 \mathrm{~cm}$. (volume de 1,8L) e durante o período de 60 segundos.

Os dados obtidos para a construção da curva de calibração de $\mathrm{Fe}^{2+}$ para o espectrofotômetro SHIMADZU UV - 2101PC são apresentados na tabela 6.11. A curva de calibração pode ser observada na figura 6.8 .

Tabela 6.11. Valores obtidos para a construção da curva de calibração de $\mathrm{Fe}^{2+}$.

\begin{tabular}{|c|c|}
\hline $\begin{array}{c}\text { Concentração de } \mathbf{F e}^{\mathbf{2 +}}\left(\mathbf{C}_{\text {medida }}\right) \\
(\mathbf{m g} / \mathbf{L})\end{array}$ & $\begin{array}{c}\text { Absorbância } \\
(\mathbf{5 1 0 n m})\end{array}$ \\
\hline 0 & 0 \\
\hline 0,55 & 0,10 \\
\hline 1,1 & 0,19 \\
\hline 1,65 & 0,31 \\
\hline 2,2 & 0,48 \\
\hline 2,75 & 0,62 \\
\hline 3,3 & 0,76 \\
\hline 4,4 & 0,98 \\
\hline 4,95 & 1,06 \\
\hline 5,5 & 1,20 \\
\hline
\end{tabular}


A equação da curva de calibração (6.1), obtida pelo método dos mínimos quadrados (MMQ), foi utilizada para calcular a concentração medida de $\mathrm{Fe}^{2+}\left(\mathrm{C}_{\text {medida }}\right)$ nos ensaios de actinometria.

$$
C_{\text {medida }}=4,4455 \times A b s+0,1061
$$

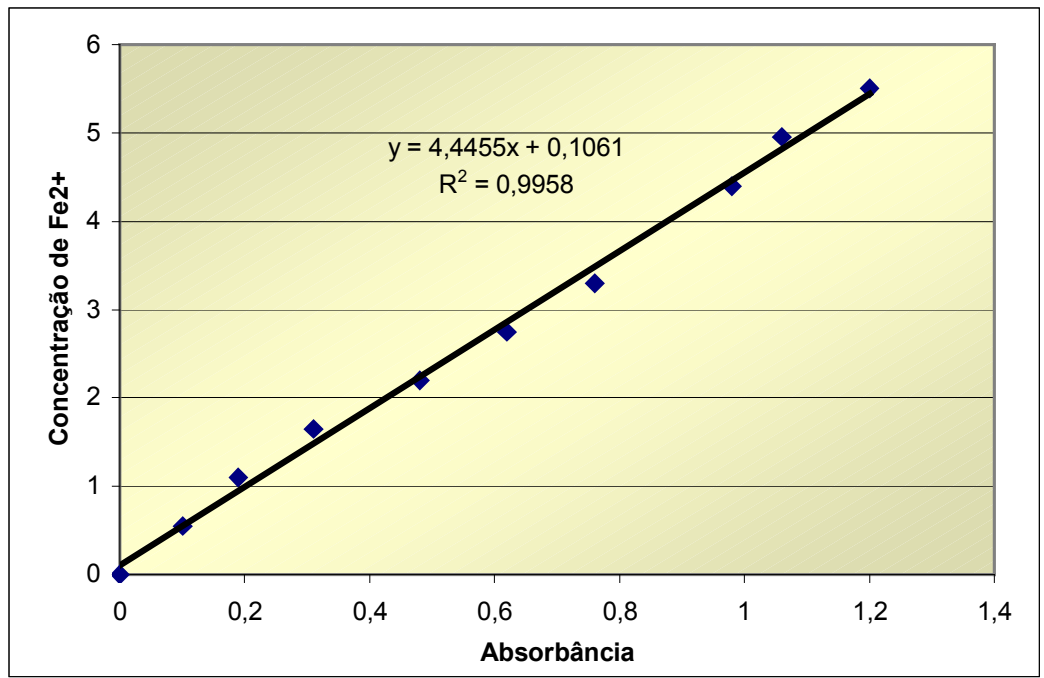

Figura 6.8. Curva de calibração de $\mathrm{Fe}^{2+}$.

Os valores médios de dose de radiação ultravioleta em $254 \mathrm{~nm}$ incidente na superfície irradiada (D) e de $\mathrm{I}_{0}$, obtidos por actinometria para 6 lâmpadas ligadas, foram calculados pelas equações (5.2) e (5.3), respectivamente, e são apresentados na tabela 6.12.

Tabela 6.12. Valores médios de dose e intensidade média de radiação UV na superfície irradiada obtidos por actinometria para 6 lâmpadas ligadas durante 60 segundos.

\begin{tabular}{|c|c|c|c|c|c|}
\hline \multicolumn{2}{|c|}{ Absorbância (510 nm) } & \multicolumn{2}{|c|}{$\mathrm{C} \mathrm{Fe}^{2+}(\mathrm{mg} / \mathrm{L})$} & \multirow{2}{*}{$\begin{array}{c}\mathbf{D}_{\mathbf{m}} \\
\left(\mathrm{mWs} / \mathrm{cm}^{3}\right)\end{array}$} & \multirow{2}{*}{$\begin{array}{c}\mathbf{I}_{\mathbf{0 m}} \\
\left(\mathrm{mW} / \mathrm{cm}^{2}\right)\end{array}$} \\
\hline $\begin{array}{c}\text { Antes } \\
\text { da Irradiação }\end{array}$ & $\begin{array}{c}\text { Depois } \\
\text { da Irradiação }\end{array}$ & $\begin{array}{c}\text { Antes } \\
\text { da Irradiação }\end{array}$ & $\begin{array}{c}\text { Depois } \\
\text { da Irradiação }\end{array}$ & & \\
\hline 0,011 & 0,236 & 7,75 & 57,76 & 33 & 5,59 \\
\hline
\end{tabular}

\subsubsection{Ensaio de desinfecção com radiação UV}

De forma análoga aos ensaios de desinfecção com ácido peracético, a desinfecção com radiação UV também foi realizada em 3 baterias. Em cada bateria foram conduzidos ensaios com 6 lâmpadas germicidas ligadas, lâmina líquida de amostra de $4 \mathrm{~cm}$ e tempos de irradiação de $30 \mathrm{e}$ 120s, sendo utilizadas amostras de efluente coletadas em datas específicas (tabela 6.13).

As intensidades médias de radiação na lâmina líquida $\left(\mathrm{I}_{\mathrm{m}}\right)$ e doses de radiação recebida $\left(\mathrm{D}_{\mathrm{r}}\right)$ para cada amostra de efluente, foram calculadas a partir do valor de $\mathrm{I}_{0 \mathrm{~m}}$ determinado por 
actinometria (vide equações 5.4 e 5.8). Os valores de $\mathrm{I}_{\mathrm{m}}$ e $\mathrm{D}_{\mathrm{r}}$ obtidos em cada ensaio de desinfecção também são apresentados na tabela 6.13 .

Tabela 6.13. Características dos ensaios de desinfecção de amostras de esgoto da ETE-Araraquara empregando radiação ultravioleta.

\begin{tabular}{|c|c|c|c|c|c|c|c|c|}
\hline Baterias & $\begin{array}{c}\text { Data de } \\
\text { coleta }\end{array}$ & Ensaios & $\begin{array}{l}\text { TC } \\
\text { (s) }\end{array}$ & $\begin{array}{c}\alpha \\
\left(\mathrm{cm}^{-1}\right)\end{array}$ & $\underset{\left(\mathrm{mW} / \mathrm{cm}^{2}\right)}{\mathbf{I}_{\mathbf{m}}}$ & $\underset{\left(\mathrm{mWs} / \mathrm{cm}^{2}\right)}{\mathrm{D}_{\mathrm{a}}}$ & $\begin{array}{c}D_{\mathbf{r}} \\
\left(\mathbf{m W s} / \mathbf{c m}^{2}\right)\end{array}$ & $\begin{array}{c}\mathbf{D}_{\mathrm{rv}} \\
\left(\mathbf{W h} / \mathbf{m}^{3}\right)\end{array}$ \\
\hline 1 & $26 / 4 / 2004$ & 1 & 30 & 1,138 & 1,215 & 167,7 & 36,46 & 2,53 \\
\hline 1 & $26 / 4 / 2004$ & 2 & 120 & 1,138 & 1,215 & 670,8 & 145,9 & 10,13 \\
\hline 2 & 05/07/2004 & 1 & 30 & 1,322 & 1,05 & 167,7 & 31,54 & 2,19 \\
\hline 2 & 05/07/2004 & 2 & 120 & 1,322 & 1,05 & 670,8 & 126,2 & 8,76 \\
\hline 3 & $17 / 11 / 2004$ & 1 & 120 & 2,123 & 0,66 & 670,8 & 78,96 & 5,48 \\
\hline
\end{tabular}

Cabe ressaltar que a dose aplicada de radiação ultravioleta $\left(D_{a}\right)$ é a energia total que atinge a superfície da lâmina líquida, sendo dependente do número de lâmpadas ligadas e do tempo de irradiação. Ao passo que a dose recebida é a energia total efetivamente disponível para a inativação dos microorganismos, a qual é influenciada não só pelo tempo de irradiação e número de lâmpadas ligadas, mas também pela qualidade da amostra desinfetada (principalmente absorbância e sólidos em suspensão) e pela espessura da lâmina líquida. Nota-se, através da tabela 6.13, que quanto maior foi o coeficiente de absorção do efluente (que é calculado a partir da absorbância), menor foi a dose recebida pela amostra e vice-versa.

$\mathrm{Na} 1^{a}$ bateria de ensaios de desinfecção, o efluente coletado em 26/04/2004 foi submetido a 2 testes. No $1^{\circ}$ e $2^{\circ}$ testes, 6 lâmpadas germicidas foram ligadas durante dois tempos de irradiação diferentes (30 segundos e 120 segundos). Sendo assim, as amostras de esgoto foram expostas à uma intensidade de energia radiante constante, porém a doses distintas, como pode ser visto na tabela 6.13. A caracterização química do esgoto coletado em 26/04/2004 submetido aos ensaios de desinfecção são mostrados na tabela 6.14 . 
Tabela 6.14. Resultados dos ensaios de desinfecção com amostras de esgoto da ETE-Araraquara coletadas em 26/04/2004 utilizando radiação ultravioleta ( $1^{\text {a }}$ bateria).

\begin{tabular}{|lccc|}
\hline \multicolumn{1}{|c}{ Variáveis } & \multicolumn{2}{c}{ UV } & Efluente \\
\hline \hline Dose recebida $\left(\mathbf{m W s} / \mathbf{c m}^{\mathbf{2}}\right)$ & $\mathbf{3 6 , 4 6}$ & $\mathbf{1 4 5 , 8 5}$ & - \\
\hline \hline Colif. Totais (NMP/100mL) & 1732,87 & 224,00 & $2,62 \times 10^{5}$ \\
Eficiência inativação colif. (\%) & 99,3380 & 99,9145 & - \\
E. coli $(\mathrm{NMP} / 100 \mathrm{~mL})$ & 23,0 & 4,0 & $3,1 \times 10^{4}$ \\
Eficiência inativação E. coli $(\%)$ & 99,9258 & 99,9871 & - \\
Absorbância bruta $(254 \mathrm{~nm})$ & 0,494 & 0,481 & 0,494 \\
Absorbância filtrada $(254 \mathrm{~nm})$ & 0,282 & 0,296 & 0,282 \\
DQO (mg/L) & 162,00 & 348,00 & 167,00 \\
ST (mg/L) & 388,00 & 384,50 & 365,50 \\
SST (mg/L) & 52,77 & 52,67 & 56,73 \\
SDT (mg/L) & 334,00 & 316,00 & 339,00 \\
Alcalinidade (mg/L) & 166,75 & 168,50 & 174,00 \\
pH & 7,85 & 7,90 & 7,61 \\
\hline
\end{tabular}

$\mathrm{Na} 2^{\text {a }}$ bateria, o efluente coletado em 05/07/2004 também foi submetido a 2 ensaios de desinfecção utilizando 6 lâmpadas ligadas durante dois tempos de irradiação diferentes (30 segundos e 120 segundos), como pode ser visto na tabela 6.15 .

Tabela 6.15. Resultados dos ensaios de desinfecção com amostras de esgoto da ETE-Araraquara coletadas em 05/07/2004 utilizando radiação ultravioleta ( $2^{\mathrm{a}}$ bateria).

\begin{tabular}{|lccc|}
\hline \multicolumn{1}{|c}{ Variáveis } & \multicolumn{2}{c}{ UV } & Efluente \\
\hline \hline Dose recebida $\left(\mathbf{m W s} / \mathbf{c m}^{\mathbf{2}}\right)$ & $\mathbf{3 1 , 5 4}$ & $\mathbf{1 2 6 , 1 8}$ & - \\
\hline \hline Colif. Totais $(\mathrm{NMP} / 100 \mathrm{~mL})$ & $>2419,2$ & $>2419,2$ & $2,613 \times 10^{6}$ \\
E. coli $(\mathrm{NMP} / 100 \mathrm{~mL})$ & 2419,2 & 72,3 & $1,89 \times 10^{5}$ \\
Eficiência inativação E. coli $(\%)$ & 98,7200 & 99,9617 & - \\
Absorbância bruta $(254 \mathrm{~nm})$ & 0,579 & 0,582 & 0,574 \\
Absorbância filtrada $(254 \mathrm{~nm})$ & 0,332 & 0,330 & 0,328 \\
DQO $(\mathrm{mg} / \mathrm{L})$ & 191,00 & 329,00 & 199,00 \\
ST $(\mathrm{mg} / \mathrm{L})$ & 389,50 & 384,00 & 377,00 \\
SST $(\mathrm{mg} / \mathrm{L})$ & 90,33 & 81,80 & 101,33 \\
SDT $(\mathrm{mg} / \mathrm{L})$ & 286,00 & 307,00 & 279,00 \\
Alcalinidade (mg/L) & 111,25 & 112,50 & 100,00 \\
pH & 7,57 & 7,59 & 7,42 \\
\hline
\end{tabular}

Finalmente, na $3^{\mathrm{a}}$ bateria foi realizado apenas um ensaio de desinfecção com amostra do efluente coletado em 17/11/2004. O ensaio foi conduzido com 6 lâmpadas ligadas durante o tempo de 120 segundos de irradiação (tabela 6.16). 
Tabela 6.16. Resultados dos ensaios de desinfecção com amostras de esgoto da ETE-Araraquara coletadas em 17/11/2004 utilizando radiação ultravioleta ( $3^{\text {a }}$ bateria).

\begin{tabular}{|lcc|}
\hline \multicolumn{1}{|c}{ Variáveis } & UV & Efluente \\
\hline \hline Dose recebida $\left(\mathbf{m W s} / \mathbf{c m}^{\mathbf{2}}\right)$ & $\mathbf{7 8 , 9 6}$ & - \\
\hline \hline Colif. Totais $(\mathrm{NMP} / 100 \mathrm{~mL})$ & $>2419,2$ & $4,884 \times 10^{6}$ \\
E. coli $(\mathrm{NMP} / 100 \mathrm{~mL})$ & 7270 & $1,012 \times 10^{6}$ \\
Eficiência inativação E. coli $(\%)$ & 99,2816 & - \\
Absorbância bruta $(254 \mathrm{~nm})$ & 0,955 & 0,922 \\
Absorbância filtrada $(254 \mathrm{~nm})$ & 0,680 & 0,691 \\
DQO $(\mathrm{mg} / \mathrm{L})$ & 188,00 & 263,00 \\
ST $(\mathrm{mg} / \mathrm{L})$ & 362,50 & 379,00 \\
SST $(\mathrm{mg} / \mathrm{L})$ & 76,93 & 81,17 \\
SDT $(\mathrm{mg} / \mathrm{L})$ & 295,20 & 286,00 \\
Alcalinidade (mg/L) & 168,75 & 170,00 \\
pH & 7,91 & 7,78 \\
\hline
\end{tabular}

Pode-se observar, a partir das tabelas 6.14 a 6.16 e da figura 6.9, que quanto maior a dose recebida, maior foi a eficiência do agente desinfetante. Como a dose recebida é dependente do tempo de irradiação e da qualidade do efluente, pôde-se notar que quanto maior o tempo de irradiação e melhor a qualidade do efluente (caracterizada pelas menores medidas de absorbância, DQO e sólidos em suspensão), maior foi a eficiência da radiação UV na inativação de $E$. coli.

A eficiência de inativação de $E$. coli nas amostras que sofreram irradiação por 30 segundos foi de 3,13 log para o efluente coletado em 26/04/2004 e de apenas 1,89 log para o efluente coletado em 05/07/2004. Essa grande variabilidade se deve à diferença de qualidade das amostras de esgoto. $\mathrm{Na} 1^{\mathrm{a}}$ bateria de testes, as medidas de absorbância, DQO e sólidos foram inferiores às da $2^{\mathrm{a}}$ bateria. 


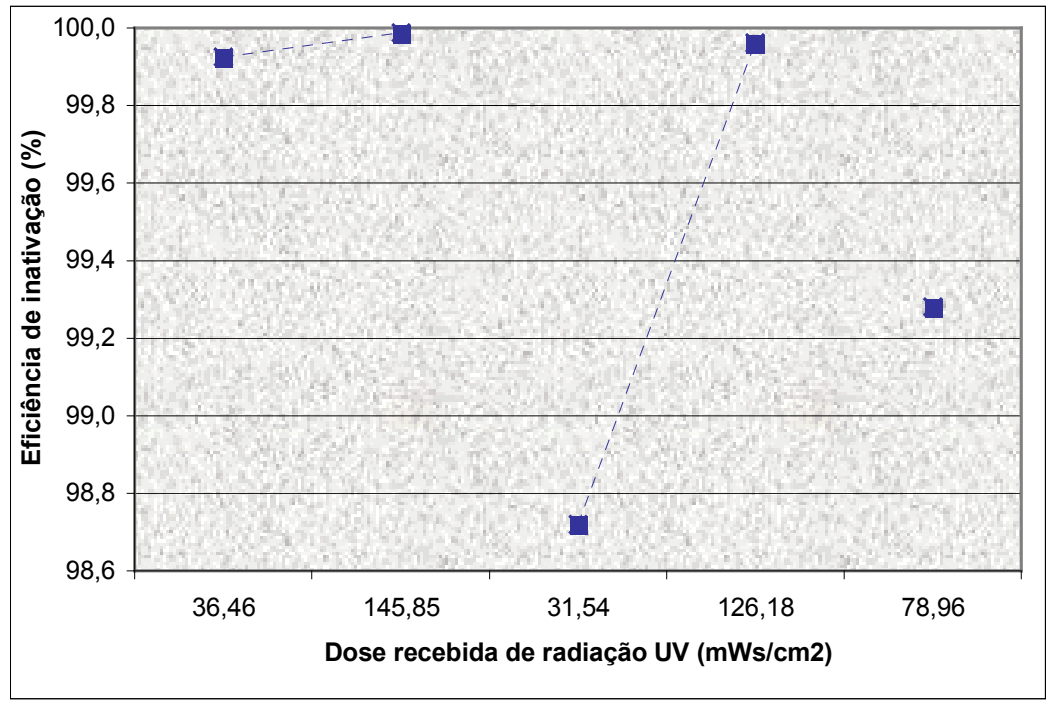

Figura 6.9. Porcentagem de inativação de $E$. coli em amostras de esgoto da ETE-Araraquara submetidas a desinfecção com radiação ultravioleta.

(Obs.: Os pontos interligados representam ensaios realizados na mesma bateria, isto é com efluentes da mesma coleta).

Esse mesmo padrão foi observado para as amostras que sofreram irradiação por 120 segundos. A melhor eficiência de inativação de E. coli foi obtida na $1^{\text {a }}$ bateria $(3,89 \log )$, onde observou-se melhor qualidade do esgoto desinfetado, enquanto que a menor eficiência foi obtida na $3^{\mathrm{a}}$ bateria $(2,14 \log )$, onde foram verificadas as maiores medidas de DQO e sólidos no efluente.

De acordo com USEPA (1999a), concentrações de sólidos em suspensão superiores a 30mg/L tornam ineficiente a desinfecção com radiação UV quando se utilizam lâmpadas de baixa pressão, como foi o caso neste estudo. Os sólidos em suspensão e a turbidez das águas residuárias prejudicam a desinfecção com radiação UV, pois a agregação ou oclusão dos microorganismos na matéria particulada impede a penetração da radiação incidente. Nesse sentido, o material em suspensão representa uma proteção aos microorganismos.

Neste estudo, as maiores concentrações de sólidos em suspensão e de matéria orgânica no efluente de fato afetaram o efeito de inativação do desinfetante sobre os microorganismos patogênicos, mas não de forma tão pronunciada, conforme relatado por USEPA (op. cit.) (figuras 6.10 e 6.11$)$. 


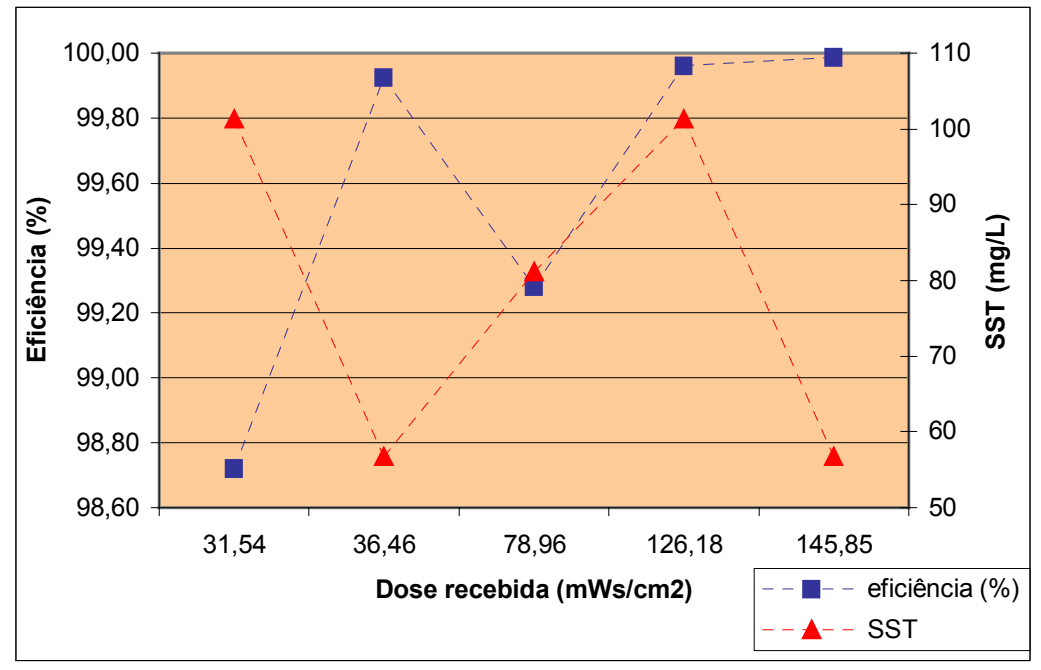

Figura 6.10. Relação entre as medidas de SST obtidas para as amostras de esgoto desinfetadas com radiação UV e eficiência de inativação de E. coli.

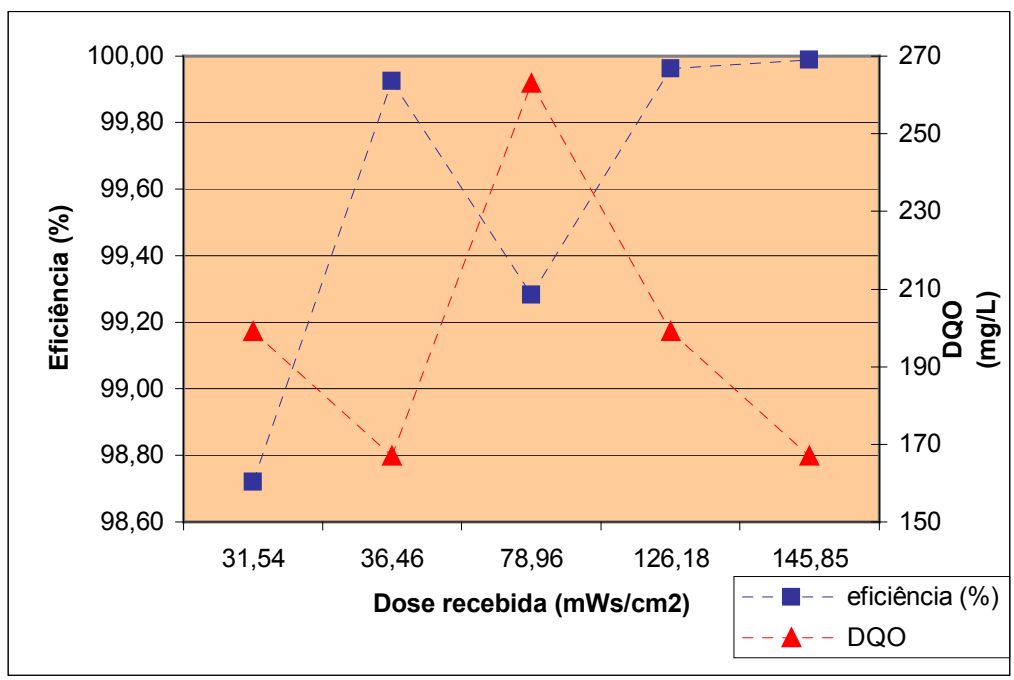

Figura 6.11. Relação entre as medidas de DQO obtidas para as amostras de esgoto desinfetadas com radiação UV e eficiência de inativação de E. coli.

Relações semelhantes às apresentadas nas figuras 6.10 e 6.11 (maior eficiência de desinfecção em amostras com menores medidas de sólidos em suspensão e DQO) foram encontradas por outros autores (ALVES, 2003; CASTRO SILVA, 2001; GONÇALVES, 2003). Mesmo assim, os referidos pesquisadores ainda demonstraram a aplicabilidade da radiação UV em efluentes com elevados teores de sólidos suspensos (acima de 90mg/L), o que também foi verificado neste estudo, indicando que a recomendação da literatura deve ser revista.

Outro parâmetro que pode influenciar a desinfecção com radiação UV é o pH, que afeta a solubilidade de metais, os quais podem absorver luz ultravioleta (valores elevados de $\mathrm{pH}$ 
possibilitam a precipitação de metais). Neste estudo, no entanto, não ocorreu grande variabilidade das medidas de $\mathrm{pH}$ nas diferentes amostras de efluente, que mantiveram-se sempre próximas à neutralidade.

A título de comparação, relacionaram-se os resultados deste estudo com os da pesquisa realizada por Coletti (2003), que analisou a eficiência da desinfecção da radiação UV em amostras de esgoto oriundas da ETE-Araraquara utilizando a mesma câmara de desinfecção.

Neste estudo, para o tempo de irradiação de 30s, foi obtida eficiência de 1,89 e 3,13 log para $\mathrm{D}_{\mathrm{rv}}$ de 2,19 e $2,53 \mathrm{Wh} / \mathrm{m}^{3}$, respectivamente. Já para o tempo de irradiação de $120 \mathrm{~s}$, foi obtida eficiência de desinfecção de 3,89 e 2,14 log para a $\mathrm{D}_{\mathrm{rv}}$ de 10,13 e $5,48 \mathrm{Wh} / \mathrm{m}^{3}$, respectivamente.

Coletti (op. cit.) verificou que a eficiência do desinfetante na inativação de $E$. coli variou de 2,21 log a 2,75 log para $\mathrm{D}_{\mathrm{rv}}$ de 1,70 e $1,24 \mathrm{Wh} / \mathrm{m}^{3}$, respectivamente, em tempos de irradiação de $30 \mathrm{~s}$, e de $4,09 \log (99,95 \%)$ e $100 \%$ para a $\mathrm{D}_{\mathrm{rv}}$ de $5,69 \mathrm{Wh} / \mathrm{m}^{3}$ e $8,62 \mathrm{Wh} / \mathrm{m}^{3}$, respectivamente, em tempos de irradiação de 120 s.

Com relação à caracterização química das amostras de esgoto desinfetadas com diferentes doses recebidas de UV, verificou-se certa estabilidade das medidas de $\mathrm{pH}$, alcalinidade, sólidos e absorbância em relação aos respectivos efluentes não desinfetados, o que é normal em função do mecanismo físico de desinfecção promovido pela radiação UV.

No entanto, foram verificadas grandes alterações das medidas de DQO somente nas amostras de efluente desinfetadas com as maiores doses de radiação UV. Nas duas primeiras baterias, a irradiação (nas doses de 145,9 e $126,2 \mathrm{mWs} / \mathrm{cm}^{2}$ ) provocou aumento da concentração de DQO do esgoto da ordem de $108 \%$ e $65 \%$, respectivamente; enquanto que na terceira bateria, houve redução na concentração da DQO de $28 \%$ para a dose de $78,96 \mathrm{mWs} / \mathrm{cm}^{2}$. A alteração dos valores de DQO do efluente após a desinfecção com radiação UV pode ter sido ocasionada por algum erro analítico.

Porém, cabe mencionar que Nurizzo et al. (2005) verificaram a redução da concentração de Carbono Orgânico Total (superior a 25\%) em amostras de esgoto desinfetadas com doses de radiação UV de $70 \mathrm{mWs} / \mathrm{cm}^{2}$, enquanto que a dose de $25 \mathrm{mWs} / \mathrm{cm}^{2}$ não provocou alteração significativa nas medidas de COT. Os autores atribuíram esse efeito à eventual mineralização do carbono orgânico a $\mathrm{CO}_{2}$.

De acordo com Nick et al. (1992) apud Nurizzo et al. (op cit.) e Otaki \& Ohgaki (1994), baixas doses de radiação UV $\left(<50 \mathrm{mWs} / \mathrm{cm}^{2}\right)$ podem afetar a decomposição de compostos orgânicos somente de forma marginal. Porém, altas doses de irradiação $\left(>1.000 \mathrm{mWs} / \mathrm{cm}^{2}\right)$, podem degradar compostos orgânicos (pesticidas, por exemplo) e gerar sub-produtos. 


\subsubsection{Desinfecção com Ozônio}

Para definir as dosagens do ozônio e tempo de contato utilizados nos ensaios de desinfecção com o esgoto oriundo da ETE-Araraquara, foi necessário quantificar a produção de ozônio gerada pelo equipamento Qualid'or.

A figura 5.9, apresentada no item "Material e Métodos", relaciona a produção de ozônio do equipamento Qualid'or com sua vazão de oxigênio.

Com base na equação da curva de calibração obtida para o gerador de ozônio, foi possível calcular as vazões de oxigênio necessárias para alcançar as doses de ozônio pré-estabelecidas.

Nesta pesquisa, foi realizada apenas uma bateria de testes com dois ensaios de desinfecção empregando o ozônio como agente desinfetante. Esses ensaios foram conduzidos com amostras de esgoto da ETE-Araraquara coletadas em 17/11/2004.

É importante salientar que a escolha da dose aplicada de ozônio foi dependente das condições operacionais dos equipamentos utilizados nos experimentos, em especial do rotâmetro. Embora a escala do rotâmetro permitisse selecionar a vazão de gás entre os limites de 0 e $400 \mathrm{~L} / \mathrm{h}$, na prática, para vazões inferiores a $15 \mathrm{~L} / \mathrm{h}$, o aparelho mostrou-se pouco preciso, sofrendo oscilações periódicas e dificultando seu ajuste.

Sendo assim, nos ensaios de desinfecção optou-se por utilizar vazões de oxigênio de $18 \mathrm{~L} / \mathrm{h}$ e $30 \mathrm{~L} / \mathrm{h}$ e tempo de contato fixado em 5 minutos. As doses aplicadas correspondentes às vazões de oxigênio utilizadas nos dois experimentos são apresentadas na tabela 6.17. Cabe observar que as doses efetivas de ozônio nos ensaios de desinfecção foram calculadas através da equação (5.11).

Tabela 6.17. Características dos ensaios de desinfecção de amostras de esgoto da ETE-Araraquara empregando ozônio.

\begin{tabular}{cccccc}
\hline \multirow{2}{*}{ Ensaios } & Vazão de $\mathrm{O}_{2}$ & Dose aplicada & Off-gas & Residual & Dose efetiva \\
\cline { 2 - 6 } & $(\mathrm{L} / \mathrm{h})$ & $(\mathrm{mg} / \mathrm{L})$ & $(\mathrm{mg} / \mathrm{L})$ & $(\mathrm{mg} / \mathrm{L})$ & $(\mathrm{mg} / \mathrm{L})$ \\
\hline $\mathbf{1}$ & $\mathbf{1 8}$ & $\mathbf{4 3 , 6}$ & $\mathbf{1 2 , 3 1}$ & $\mathbf{1 , 4 4}$ & $\mathbf{2 9 , 9 0}$ \\
$\mathbf{2}$ & $\mathbf{3 0}$ & $\mathbf{6 6 , 5}$ & $\mathbf{1 9 , 8 5}$ & $\mathbf{1 , 5 6}$ & $\mathbf{4 5 , 1 3}$ \\
\hline
\end{tabular}

Analisando a tabela 6.17 , observa-se que as doses de ozônio efetivamente consumidas pelas amostras de esgoto desinfetadas foram de $68,5 \%$ ( $1^{\circ}$ ensaio) e de $67,8 \%$ ( $2^{\circ}$ ensaio) em relação às respectivas doses aplicadas, indicando que a porcentagem de ozônio absorvido não foi afetada pela variação da vazão de oxigênio.

Monaco (2006), em seu estudo de desinfecção de esgoto sanitário oriundo de tratamento anaeróbio em reator UASB, também verificou que cerca de $60 \%$ da dose teórica de ozônio aplicada em seus experimentos foi efetivamente consumida. Deve-se ressaltar que a referida autora utilizou a mesma instalação piloto e o mesmo equipamento gerador de ozônio utilizados no presente estudo. 
Segundo a autora, a diminuição da taxa de ozônio absorvido pode estar associada principalmente às limitações de desempenho inerentes ao sistema de desinfecção utilizado na pesquisa, tais como configuração e dimensionamento da câmara de ozonização, por exemplo.

Na tabela 6.18, é apresentada a caracterização química e bacteriológica do esgoto submetido aos ensaios de desinfecção com ozônio.

A partir da tabela 6.18 e figura 6.12 , fica claro que a maior dose efetiva de ozônio provocou maior inativação de coliformes totais e E. coli presentes no esgoto. Obteve-se 2,067 log de eficiência de inativação de $E$. coli para a dose de $29,9 \mathrm{mgO}_{3} / \mathrm{L}$ e de $3,551 \mathrm{log}$ para a dose de $45,13 \mathrm{mgO}_{3} / \mathrm{L}$.

Sartori (2004), ao analisar o efeito do ozônio na inativação de E. coli em amostras do esgoto sanitário proveniente da ETE-Araraquara, verificou eficiência de cerca de 3 log para concentração efetiva de $30 \mathrm{mgO}_{3} / \mathrm{L}$ e TC de $10 \mathrm{~min}$. e de $1,064 \log$ para a concentração de $27 \mathrm{mgO}_{3} / \mathrm{L}$ e TC de 10min. Deve-se ressaltar que esses resultados foram obtidos para amostras de esgoto coletadas em datas diferentes, o que explica a grande variabilidade da eficiência do agente desinfetante na inativação de E. coli no referido estudo. A autora também verificou que quanto maior a dose efetiva de ozônio e o tempo de contato, maior foi sua eficiência na inativação da bactéria.

Tabela 6.18. Resultados dos ensaios de desinfecção com amostras de esgoto da ETE-Araraquara coletadas em 17/11/2004 utilizando ozônio.

\begin{tabular}{|lccc|}
\hline \multicolumn{1}{|c}{ Variáveis } & \multicolumn{2}{c|}{ Ozônio } & Efluente \\
\hline \hline Dose efetiva (mg/L) & $\mathbf{2 9 , 9 0}$ & $\mathbf{4 5 , 1 3}$ & - \\
\hline \hline Residual (mg/L) & 1,44 & 1,56 & - \\
Colif. Totais (NMP/100mL) & 24197 & 4838,3 & $4,884 \times 10^{6}$ \\
Eficiência inativação colif. (\%) & 99,5045 & 99,9009 & - \\
E. coli $(\mathrm{NMP} / 100 \mathrm{~mL})$ & 8664 & 1373,4 & $1,012 \times 10^{6}$ \\
Eficiência inativação E. coli $(\%)$ & 99,1439 & 99,9719 & - \\
DQO (mg/L) & 152 & 135 & 263 \\
ST (mg/L) & 352,5 & 355,5 & 379,0 \\
SST (mg/L) & 42,43 & 40,83 & 81,17 \\
SDT (mg/L) & 307,0 & 312,0 & 286,0 \\
Alcalinidade (mg/L) & 162,5 & 159,5 & 170 \\
pH & 7,74 & 7,89 & 7,78 \\
\hline
\end{tabular}




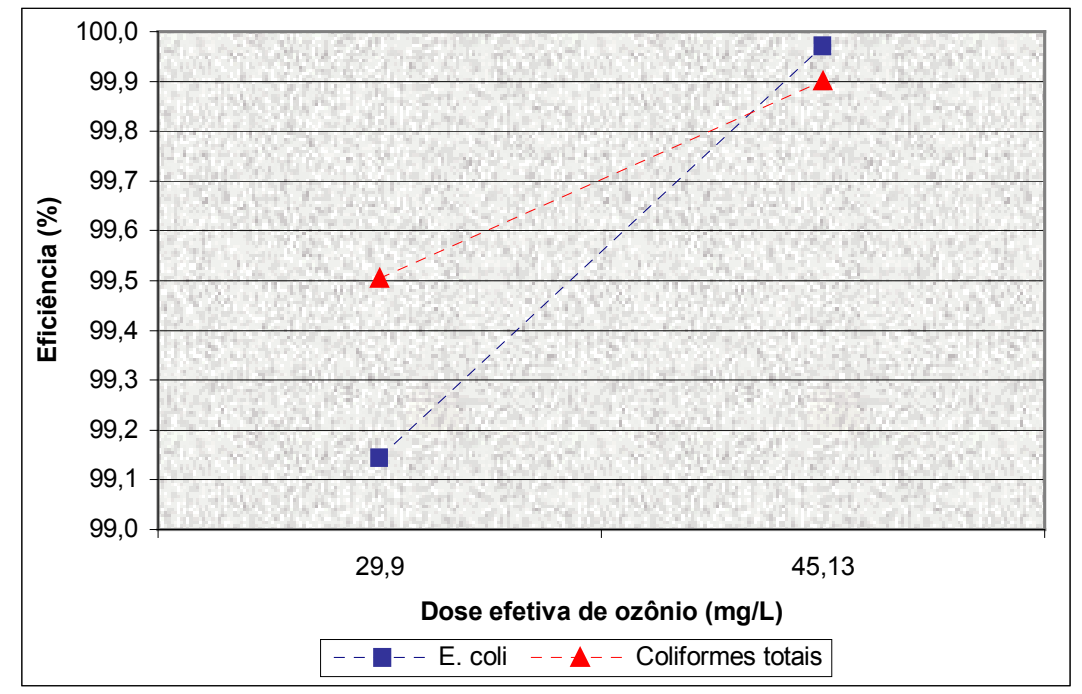

Figura 6.12. Porcentagem de inativação de E. coli e coliformes totais em amostras de esgoto da ETEAraraquara submetidas a desinfecção com ozônio.

Com relação às características químicas do esgoto após a desinfecção, notou-se considerável redução da concentração de DQO (de $42 \%$ e 48\%, para os ensaios 1 e 2 , respectivamente) e de sólidos em suspensão (de $47 \%$ e $50 \%$, para os ensaios 1 e 2, respectivamente) em relação ao esgoto não desinfetado, indicando que parte do agente desinfetante foi consumida na oxidação do material orgânico presente no esgoto, o que pode ter diminuído a eficiência das reações de inativação das bactérias. Deve-se observar ainda que as menores concentrações de DQO e sólidos em suspensão foram obtidas para amostras de esgoto submetidas à maior dose efetiva de ozônio.

As medidas de pH não sofreram grandes alterações após a desinfecção do esgoto, se mantendo entre 7,7 e 7,9 unidades de pH. De acordo com Lapolli et al. (2003), a maioria dos dados disponíveis na literatura indica que a eficiência da desinfecção por ozônio é pouco afetada na faixa de $\mathrm{pH}$ dos efluentes domésticos, isto é, entre 6 e 8.

As concentrações de alcalinidade do esgoto após a desinfecção sofreram um pequeno decréscimo em relação ao esgoto não desinfetado; porém, suas medidas permaneceram elevadas. Segundo Langlais et al. (1991), concentrações relativamente elevadas de alcalinidade inibem o desenvolvimento das reações radicalares não-seletivas (mecanismo indireto de oxidação), reduzindo a decomposição do ozônio. Como os radicais livres $\mathrm{HO}_{2}$ e hidroxilas $\left(\mathrm{OH}^{-}\right)$apresentam capacidade de oxidação inferior a do $\mathrm{O}_{3}$, altos valores de alcalinidade beneficiam o mecanismo direto ou molecular de oxidação, resultando em maior eficiência de inativação de microorganismos. Ademais, o principal constituinte da alcalinidade em $\mathrm{pH}$ na faixa de 4,4 a 8,3 são os bicarbonatos, o quais provocam um efeito estabilizante sobre o ozônio. 


\subsubsection{Desinfeç̧ão com Cloro}

Neste estudo, foi realizada apenas uma bateria de ensaios de desinfecção com hipoclorito de sódio, sendo utilizadas amostras de esgoto oriundas da ETE-Araraquara coletadas em 17/11/2004. Nessa bateria foram conduzidos experimentos com concentrações de cloro de 2,5 e 7,0 mg/L e tempos de contatos de 20 e 40 minutos, conforme descrito na tabela 6.19.

Tabela 6.19. Características dos ensaios de desinfecção de amostras de esgoto da ETE-Araraquara empregando cloro.

\begin{tabular}{|ccc|}
\hline Ensaios & $\begin{array}{c}\text { Concentração } \\
(\mathbf{m g} / \mathbf{L})\end{array}$ & $\begin{array}{c}\text { Tempo de Contato } \\
(\mathbf{m i n})\end{array}$ \\
\hline \hline 1 & 2,5 & 20 \\
2 & 2,5 & 40 \\
3 & 7,0 & 20 \\
4 & 7,0 & 40 \\
\hline
\end{tabular}

Na tabela 6.20, é apresentada a caracterização química e bacteriológica do esgoto submetido aos ensaios de desinfecção com cloro.

Tabela 6.20. Resultados dos ensaios de desinfecção com amostras de esgoto da ETE-Araraquara coletadas em 17/11/2004 utilizando cloro.

\begin{tabular}{|lccccc|}
\hline \multicolumn{1}{|c}{ Variáveis } & \multicolumn{2}{c}{ Cloro } & Efluente \\
\hline \hline Concentração (mg/L) & $\mathbf{2 , 5}$ & $\mathbf{2 , 5}$ & $\mathbf{7 , 0}$ & $\mathbf{7 , 0}$ & - \\
Tempo de Contato (min.) & $\mathbf{2 0}$ & $\mathbf{4 0}$ & $\mathbf{2 0}$ & $\mathbf{4 0}$ & - \\
\hline \hline Residual Livre (mg/L) & 0,03648 & $<0,026$ & 0,48714 & 0,17634 & - \\
Residual Total (mg/L) & 0,19188 & $<0,026$ & 2,92692 & 2,41928 & - \\
Colif. Totais (NMP/100mL) & $>24.192$ & 7.701 & 1,00 & 1,00 & $4,884 \times 10^{6}$ \\
Eficiência inativação colif. (\%) & - & 99,8423 & 99,9999 & 99,9999 & - \\
E. coli $(\mathrm{NMP} / 100 \mathrm{~mL})$ & 62 & 30 & $>1$ & $>1$ & $1,012 \times 10^{6}$ \\
Eficiência inativação E. coli $(\%)$ & 99,9939 & 99,9970 & 100 & 100 & - \\
DQO (mg/L) & 177,00 & 191,00 & 186,00 & 169,00 & 263,00 \\
ST (mg/L) & 393,50 & 363,50 & 364,50 & 394,00 & 379,00 \\
SST (mg/L) & 87,75 & 92,90 & 77,60 & 81,85 & 81,17 \\
SDT (mg/L) & 284,00 & 301,00 & 295,00 & 279,00 & 286,00 \\
Alcalinidade (mg/L) & 168,50 & 169,50 & 169,50 & 170,00 & 170,00 \\
pH & 7,65 & 7,61 & 7,73 & 7,66 & 7,78 \\
\hline
\end{tabular}

A tabela 6.20 e a figura 6.13 mostram que a concentração de $7 \mathrm{mg} / \mathrm{L}$ de cloro foi mais eficiente na inativação de coliformes totais e $E$. coli do que a concentração de $2,5 \mathrm{mgCl}_{2} / \mathrm{L}$, o que era esperado.

A concentração de $7 \mathrm{mgCl}_{2} / \mathrm{L}$ provocou a eliminação de $100 \%$ de E. coli presente no esgoto, independentemente do tempo de contato utilizado no ensaio de desinfecção. 
Já para o tratamento com 2,5mg/L de cloro, o tempo de contato influenciou na eficiência de desinfecção. O ensaio com 40 minutos de duração mostrou-se mais efetivo na remoção de coliformes totais e E. coli (2,82 log e 4,523 log, respectivamente) do que o com 20 minutos (inferior a 2,4 $\log$ e 4,215 log, respectivamente).

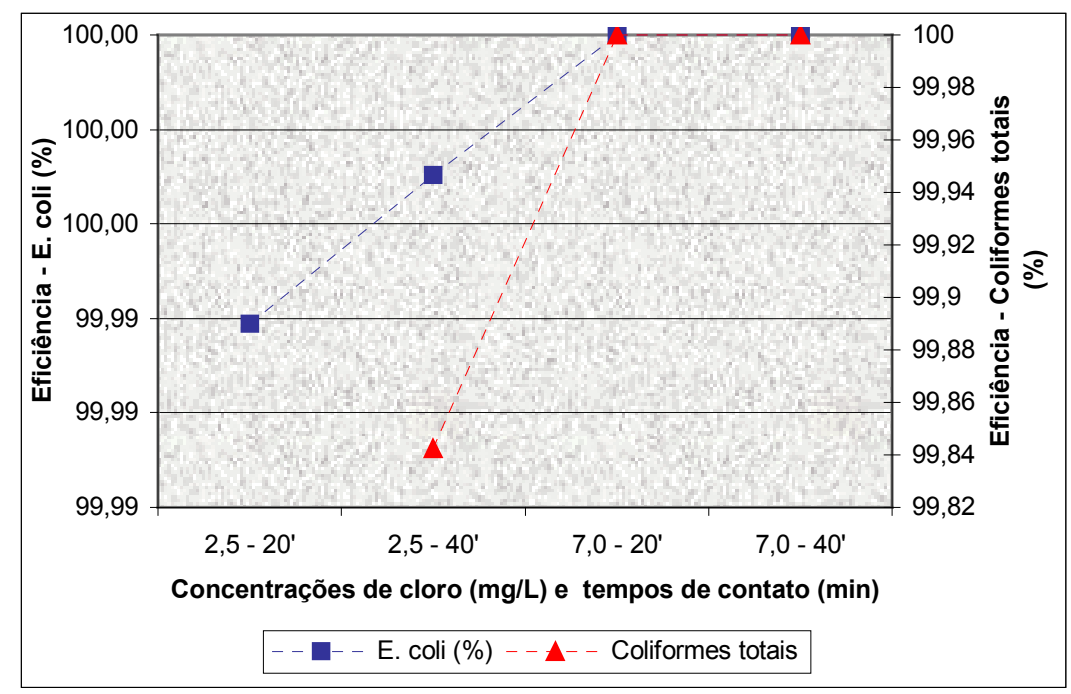

Figura 6.13. Porcentagem de inativação de E. coli e coliformes totais em amostras de esgoto da ETEAraraquara submetidas a desinfecção com cloro.

Razzolini (2003), ao estudar a viabilidade da utilização dos esgotos sanitários tratados pelo sistema de lagoas de estabilização do município de Lins (SP) na irrigação de áreas agrícolas, observou que nas amostras de esgoto submetidas à desinfecção com hipoclorito de sódio houve variação na densidade de coliformes totais e E. coli dependendo da dosagem e tempo de contato aplicados, sendo encontrados alguns valores similares aos obtidos neste estudo. A autora verificou eficiência superior a $6 \log$ na inativação de E.coli para a concentração de 8mg/L de cloro aplicado e TC de 30 minutos e de 2,53 log na inativação de coliformes totais para concentração de $2,1 \mathrm{mg} / \mathrm{L}$ de cloro e 12 minutos de TC.

Aisse et al. (2003) afirmam que a dosagem típica para desinfecção de efluentes de lagoas de estabilização para obter um padrão de lançamento de $1.000 \mathrm{NMP} / 100 \mathrm{~mL}$ de coliformes fecais deve estar entre 6 a 13mg/L de hipoclorito de sódio.

Neste estudo verificou-se que a concentração de $2,5 \mathrm{mg} / \mathrm{L}$ de cloro já foi suficiente para atingir níveis de inativação de coliformes totais e E. coli significativos. Deve-se levar em consideração, no entanto, que o presente estudo foi realizado em escala laboratorial.

Andrade Neto et al. (2002a e 2002b) compararam a eficiência de desinfecção de efluente de filtros anaeróbios por hipoclorito de sódio em três escalas de experimentos (escala laboratorial, piloto e real). De acordo com os referidos autores, para atingir resultados equivalentes em termos de 
remoção bacteriológica, nos ensaios em escala piloto e escala real foram necessárias concentrações de cloro bem superiores às obtidas nos ensaios de laboratório. Nos ensaios em laboratório as demandas de cloro estiveram na faixa de 2,5 a 3,0mg/L, enquanto que nos tanques de contato em escala piloto as demandas foram da ordem de 6,0 a 7,0 $\mathrm{mgCl}_{2} / \mathrm{L}$ e em escala real a demanda foi ainda maior. Segundo os autores, isso confirma a importância da hidrodinâmica na eficiência de desinfecção, já que a escala de laboratório apresentava condições de mistura ótimas enquanto que as escalas piloto e real apresentavam condições de mistura e dispersão desfavoráveis. Deve-se considerar também outros fatores, tais como as variações de temperatura nos ensaios de campo, as quais devem influenciar na eficiência da desinfecção por cloro.

Com relação às concentrações de cloro residual presentes nas amostras de esgoto após a desinfecção, neste estudo foram medidos o cloro livre residual $\left(\mathrm{HOCl}\right.$ e $\left.\mathrm{OCl}^{-}\right)$e o cloro total residual, sendo que o cloro combinado residual (monocloramina, dicloramina e tricloramina) foi calculado a partir da diferença entre as concentrações residuais de cloro total e livre.

Neste trabalho, observou-se que a demanda de cloro (calculada pela diferença entre a concentração inicial aplicada e a residual total) nos diferentes experimentos foi diretamente proporcional ao aumento da concentração de cloro aplicada e inversamente proporcional ao tempo de contato.

Para o esgoto tratado com 2,5mg/L de cloro e 40 minutos de tempo de contato, a demanda do desinfetante foi integral (a concentração de cloro residual ficou abaixo do limite de detecção do método utilizado para sua análise); isto é, todo o cloro aplicado foi consumido pelos vários constituintes da água residuária (figura 6.14).

Nos outros tratamentos, observou-se que as concentrações residuais de cloro combinado foram consideravelmente superiores aos residuais de cloro livre. Esse resultado indica que houve elevado consumo de cloro livre ao longo dos ensaios e que o cloro aplicado nas amostras reagiu com compostos presentes no esgoto, em especial com a amônia, formando cloraminas, as quais apresentam poder desinfetante bem inferior ao do cloro livre. Mesmo assim, a eficiência de desinfecção desse oxidante foi considerada elevada em todos os casos (superior a $4 \log$ para $E$. coli). 


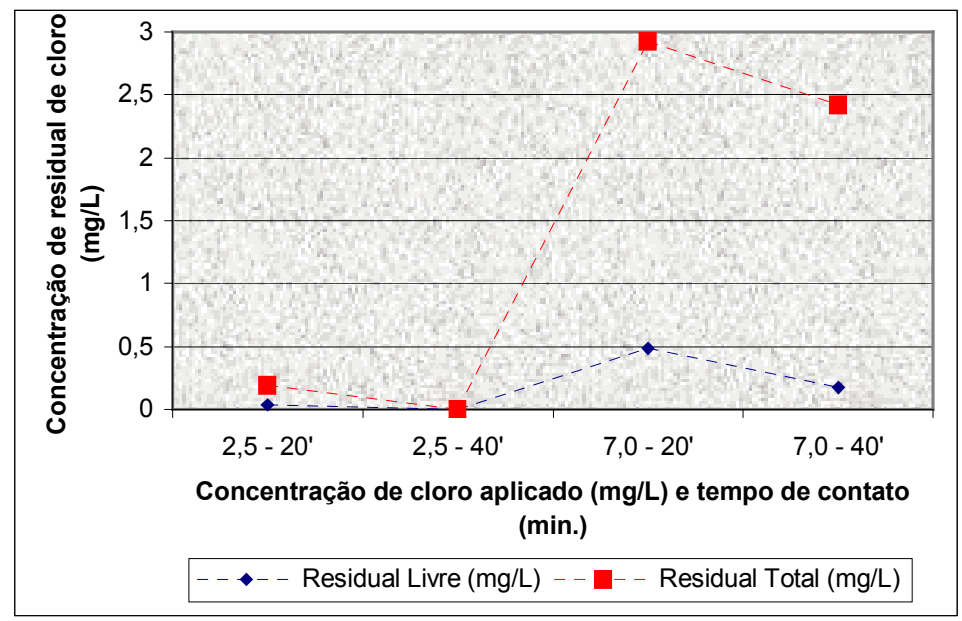

Figura 6.14. Concentrações de cloro residual livre e total obtidas nas amostras de esgoto da ETE-Araraquara submetidas aos ensaios de desinfecção com cloro.

Nota-se que, para a concentração de $7 \mathrm{mg} / \mathrm{L}$ de cloro, os valores de cloro residual ficaram acima de $2 \mathrm{mg} / \mathrm{L}$, indicando que a dose aplicada do cloro foi bastante superior à necessária para a inativação das bactérias indicadoras utilizadas neste estudo, já que ao final dos ensaios a concentração de E. coli foi nula.

Deve-se observar que os valores de cloro residual livre encontrados neste estudo ficaram abaixo do limite máximo estabelecido para água para consumo humano no Brasil, que é de $5 \mathrm{mgCl}_{2} / \mathrm{L}$ (BRASIL, 2005).

Quanto às características químicas do esgoto após a desinfecção (tabela 6.20), notou-se considerável redução da concentração de DQO em relação ao esgoto não desinfetado (mínima de $27 \%$ e máxima de $36 \%$, para os ensaios 2 e 4 , respectivamente), indicando que parte do agente desinfetante foi consumida na oxidação do material orgânico presente no esgoto, o que pode ter diminuído a eficiência das reações de inativação das bactérias.

Já com relação aos sólidos em suspensão, não observou-se uniformidade dos seus valores após a desinfecção. Porém, não foram identificadas grandes variações em relação ao esgoto não desinfetado.

As medidas de $\mathrm{pH}$ e alcalinidade sofreram pequenas reduções em suas medidas após a desinfecção do esgoto. $\mathrm{O}$ pH manteve-se entre 7,61 e 7,73 e a alcalinidade entre 168,5 e 170. Devese lembrar que o mecanismo de desinfecção do cloro é pH-dependente, sendo mais eficiente em meio mais ácido, uma vez que o ácido hipocloroso $(\mathrm{HOCl})$, que é o produto resultante da dissociação do cloro na água com maior efeito germicida, não se dissocia em pH abaixo de 6,5 (DANIEL, 2001).

Além das análises das variáveis químicas acima descritas, neste estudo também foi verificada a formação de 4 trihalometanos (clorofórmio, bromodiclorometano, dibromoclorometano 
e bromofórmio) em amostras de esgoto no período de 24 e 48 horas após à adição do cloro nas duas concentrações testadas (tabela 6.21 e figura 6.15).

Tabela 6.21. Formação de trihalometanos após a aplicação de cloro nas amostras esgoto da ETE-Araraquara coletadas em 17/11/2004.

\begin{tabular}{|lcccc|}
\hline \multicolumn{1}{|c}{ Variáveis } & \multicolumn{5}{c|}{ Cloro } \\
\hline \hline Concentração $(\mathbf{m g} / \mathbf{L})$ & $\mathbf{2 , 5}$ & $\mathbf{2 , 5}$ & $\mathbf{7}$ & $\mathbf{7}$ \\
Tempo $(\mathbf{h})$ & $\mathbf{2 4}$ & $\mathbf{4 8}$ & $\mathbf{2 4}$ & $\mathbf{4 8}$ \\
\hline \hline Clorofórmio $(\mu \mathrm{g} / \mathrm{L})$ & 29,6 & 28,66 & 28,55 & 30,53 \\
Bromodiclorometano $(\mu \mathrm{g} / \mathrm{L})$ & 10,37 & 9,46 & 9,3 & 10,24 \\
Dibromoclorometano $(\mu \mathrm{g} / \mathrm{L})$ & $<1,0$ & $<1,0$ & $<1,0$ & $<1,0$ \\
Bromofórmio $(\mu \mathrm{g} / \mathrm{L})$ & $<1,0$ & $<1,0$ & $<1,0$ & $<1,0$ \\
Total $(\boldsymbol{\mu g} / \mathbf{L})$ & $\mathbf{3 9 , 9 7}$ & $\mathbf{3 8 , 1 2}$ & $\mathbf{3 7 , 8 5}$ & $\mathbf{4 0 , 7 7}$ \\
\hline
\end{tabular}

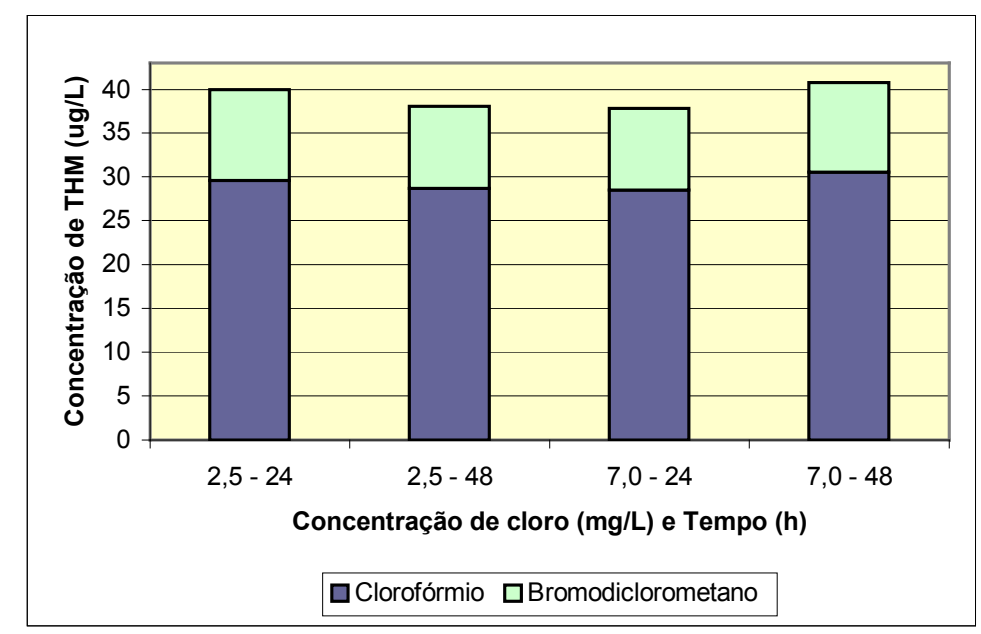

Figura 6.15. Concentrações de clorofórmio e bromodiclorometano obtidas nas amostras de esgoto da ETEAraraquara submetidas aos ensaios de desinfecção com cloro após 24 e $48 \mathrm{~h}$ de exposição.

A partir da tabela 6.21 e figura 6.15, pode-se verificar que o clorofórmio foi o composto organoclorado predominantemente detectado nas amostras de esgoto após a cloração, sendo seguido pelo bromodiclorometano. Quanto ao dibromoclorometano e ao bromofórmio, não foi verificada a formação desses compostos no efluente após a cloração.

Segundo Sanches et al. (2003), o clorofórmio é o mais abundante dos THMs em águas cloradas, enquanto que os outros três são formados quando há íons brometo complexados às substâncias húmicas.

De uma maneira geral, não foi verificada relação entre a concentração de cloro aplicada e a formação dos THMs, uma vez que os valores obtidos variaram pouco.

Da mesma forma, também não ficou evidenciada grande variação na formação dos THMs com o decorrer do tempo. De acordo com Santos (1988), vários fatores influenciam 
simultaneamente na velocidade de formação de THMs, não sendo possível predizer o tempo de reação em função da complexidade das reações envolvidas e da mistura de estruturas desconhecidas. Souza (2006) afirma que, em algumas circunstâncias, a formação de THMs pode completar-se em menos de 1 hora, porém, em outras ocasiões, é possível que se exijam vários dias antes que ocorra a máxima produção desses compostos organoclorados.

De qualquer forma, aceita-se como regra geral que quanto maior a temperatura e o $\mathrm{pH}$ da amostra, maior será a probabilidade de formação de THMs e mais rápida será a reação. A presença de brometos e iodetos também favorece a formação desses compostos, assim como a maior concentração de matéria orgânica presente no efluente.

De acordo com WEF (1996), apesar dos efluentes de sistemas de tratamento possuírem muitos precursores da formação de THMs (tais como substâncias orgânicas, ácidos húmicos, fúlvicos e himatomelânicos, compostos aromáticos, etc.), a quantidade desses compostos nos esgotos clorados pode ser pequena em função da seletividade da reação com a amônia e da menor velocidade de reação com os compostos formadores de THMs na presença de cloro livre ou combinado.

Neste estudo, o maior valor de THM total encontrado foi de $40,77 \mu \mathrm{g} / \mathrm{L}$, o qual encontra-se abaixo do padrão ambiental americano para reuso público, que foi fixado em $80 \mu \mathrm{g} / \mathrm{L}$ (USEPA, 2001), e abaixo do padrão de potabilidade brasileiro para água para consumo humano, que é de $100 \mu \mathrm{g} / \mathrm{L}$ de THMs (BRASIL, 2005).

Deve-se ressaltar, no entanto, que os THMs são apenas uma parcela dos subprodutos da desinfecção por cloro, sendo indicadores da possível presença de outros compostos organoclorados subprodutos da cloração (ácidos acéticos clorados, haloacetonitrilos, cloropicrin, clorofenóis, cloropropanonas), os quais podem ser mais perigosos do que os próprios THMs.

Comparando todos os métodos de desinfecção estudados, pode-se considerar que, nas condições testadas, todos os desinfetantes foram bem sucedidos na inativação de E. coli. Essa afirmativa é verdadeira principalmente quando se considera que a desinfecção de esgotos, diferentemente da água, não exige inativação total dos microorganismos patogênicos, podendo-se exigir maior ou menor eficiência em função do uso a que se destina o efluente desinfetado.

Em termos gerais, para as doses e tempos de contato testados e para a mesma amostra de efluente, verificou-se a seguinte ordem decrescente de eficiência de inativação de E. coli: cloro > ácido peracético $>$ ozônio $>$ radiação UV. Resultados semelhantes também foram relatados por outros autores.

Tyrrell et al. (1995) compararam o efeito do cloro e ozônio na inativação de bactérias e vírus provenientes de efluentes secundários de esgoto sanitário e concluíram que o cloro é um bactericida mais efetivo do que o ozônio, porém é um virucida menos eficiente do que o ozônio. 
Razzolini (2003) também verificou que o ozônio foi menos efetivo do que o cloro na remoção de E. coli e coliformes totais do esgoto sanitário tratado pelo sistema de lagoas de estabilização do município de Lins (SP).

Já Sartori (2004), concluiu que o ácido peracético tem maior poder bactericida do que o ozônio.

De acordo com Shaban et al (1997) apud Daniel (2001), as doses de radiação UV necessárias para a promover a inativação de bactérias do grupo coliforme podem ser mais efetivas do que a cloração. Deve-se ressaltar, no entanto, que a qualidade do esgoto a ser desinfetado interfere na eficiência de desinfecção da radiação UV, o que deve ter sido verificado neste estudo.

Paraskeva \& Graham (2005), ao estudar métodos de desinfecção a um efluente municipal secundário, verificaram que o ozônio, nas doses de 7 a $10 \mathrm{mg} / \mathrm{L}$ foram mais efetivos na inativação de coliformes totais e E. coli do que a radiação UV nas doses que variaram entre 250 e 400 $\mathrm{mWs} / \mathrm{cm}^{2}$. Os autores acreditam que, para aumentar a efetividade do UV, haveria a necessidade de promover uma filtração do efluente anteriormente à desinfecção.

\subsubsection{Avaliação ecotoxicológica do esgoto tratado após os ensaios de desinfecção}

Diversas variáveis devem ser consideradas na escolha de um processo de desinfecção de esgoto sanitário, tais como: a eficiência de desinfecção em termos de inativação de diversos microorganismos e parasitas, relação entre dose do desinfetante requerida e características do esgoto, custo, facilidade de manipulação, riscos à saúde dos trabalhadores, potenciais efeitos adversos à vida aquática, etc (GONÇALVES, 2003).

Com o objetivo de responder pelo menos uma das questões acima mencionadas, este estudo procurou agregar conhecimentos em relação ao potencial tóxico que alguns agentes desinfetantes, quando utilizados na desinfecção de esgotos sanitários, podem provocar em organismos representativos da biota aquática, já que não são encontrados muitos dados na literatura nacional sobre esse assunto em específico.

Neste tópico serão descritos os resultados dos testes de toxicidade com amostras de esgoto provenientes da ETE-Araraquara após os ensaios de desinfecção com ácido peracético, radiação UV, ozônio e hipoclorito de sódio, utilizando D. similis, D. rerio, C. xanthus, C. silvestrii e A. cepa como organismos-teste.

Os bioensaios foram divididos em 3 baterias. A primeira bateria de testes de toxicidade foi realizada com amostras de esgoto coletadas em 26/04/2004, as quais foram submetidas a ensaios de desinfecção com ácido peracético e radiação ultravioleta. A segunda bateria utilizou amostras de esgoto coletadas em 05/07/2004, onde foram novamente realizados ensaios de desinfecção com 
ácido peracético e radiação UV. E, por fim, a terceira bateria foi realizada com o esgoto amostrado em 17/11/2004, o qual foi submetido a ensaios de desinfecção com ácido peracético, radiação UV, cloro e ozônio.

\subsubsection{Avaliação ecotoxicológica do esgoto tratado após os ensaios de desinfecção $-1^{\mathrm{a}}$ Bateria}

Para os ensaios de desinfecção com ácido peracético e radiação ultravioleta realizados com amostras de esgoto tratado da ETE-Araraquara coletadas em 26/04/2004, os resultados dos testes de toxicidade podem ser visualizados nas tabelas A-I.5 a A-I.10 (Anexo I).

\section{D. similis:}

Nos bioensaios com D. similis (tabela A-I.5 e figura 6.16), as análises estatísticas identificaram diferença significativa entre o controle e todos os tratamentos com ácido peracético, já que foi observada imobilidade dos organismos superior a $50 \%$ nas concentrações de 5 e $10 \mathrm{mg} / \mathrm{L} \mathrm{de}$ PAA e tempos de contato de 20 e 40 minutos. Os outros tratamentos (efluente não desinfetado e efluente submetido a desinfecção por radiação ultravioleta) não causaram efeito tóxico à $D$. similis.

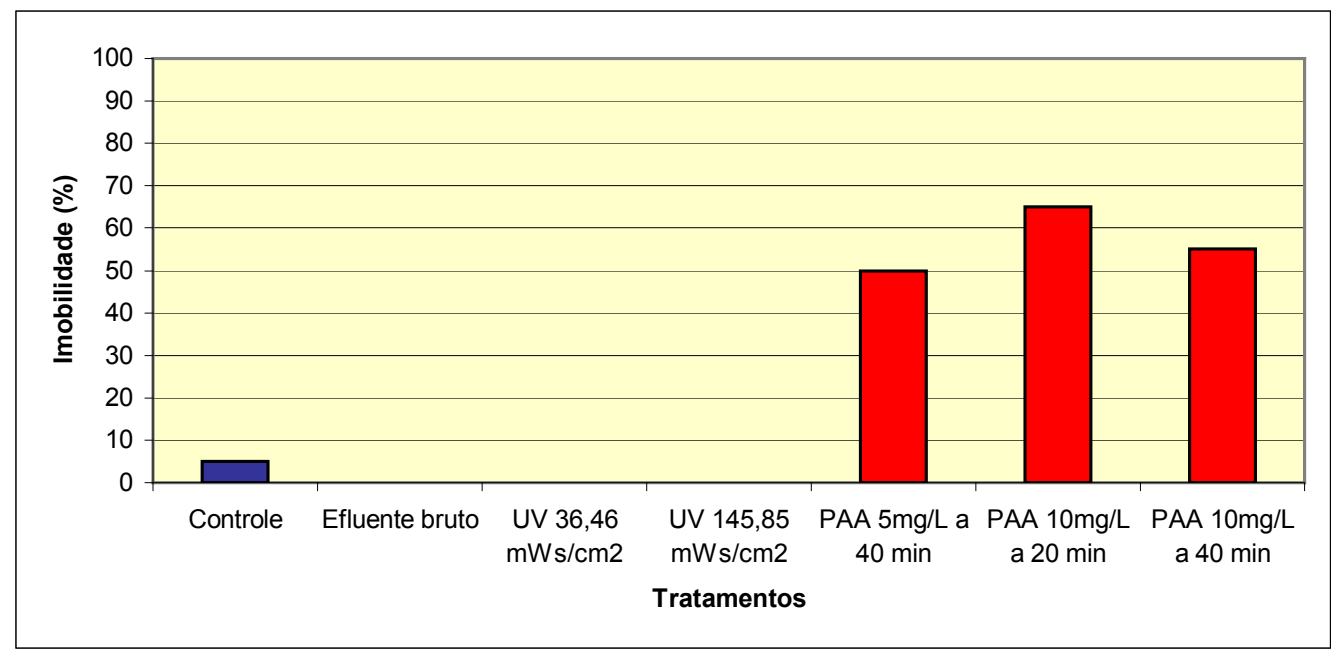

Figura 6.16. Porcentagem de imobilidade de $D$. similis expostas a amostras de esgoto coletadas em 26/04/2004 antes e após desinfecção com UV e PAA.

(Tratamentos em vermelho indicam valores significativamente diferentes do controle).

Nota-se que a maior concentração de PAA testada $(10 \mathrm{mg} / \mathrm{L})$ no menor tempo de contato $(20$ minutos) provocou maior imobilidade nesse organismo (65\%).

É importante observar que o teste estatístico de Kruskal-Wallis evidenciou diferença significativa entre os experimentos com amostra de esgoto não desinfetado e amostras de esgoto 
desinfetado com ácido peracético, o que indica que a adição do ácido peracético ao efluente, o tornou tóxico ao Cladocera.

Também foi verificada diferença significativa entre os experimentos de desinfecção com radiação UV e com PAA, indicando que, para $D$. similis, a desinfecção do efluente com a radiação UV seria a mais adequada nas condições testadas.

\section{D. rerio:}

Nos bioensaios com $D$. rerio foi verificada toxicidade aguda para todos os tratamentos testados, sendo que a amostra de efluente desinfetado com radiação UV na dose recebida de 145,85 $\mathrm{mWs} / \mathrm{cm}^{2}$ causou a maior mortalidade desse organismo (80\%), enquanto que a amostra de efluente não desinfetado provocou mortalidade de $26,6 \%$ ao peixe, como pode ser observado na tabela A-I.6 e figura 6.17.

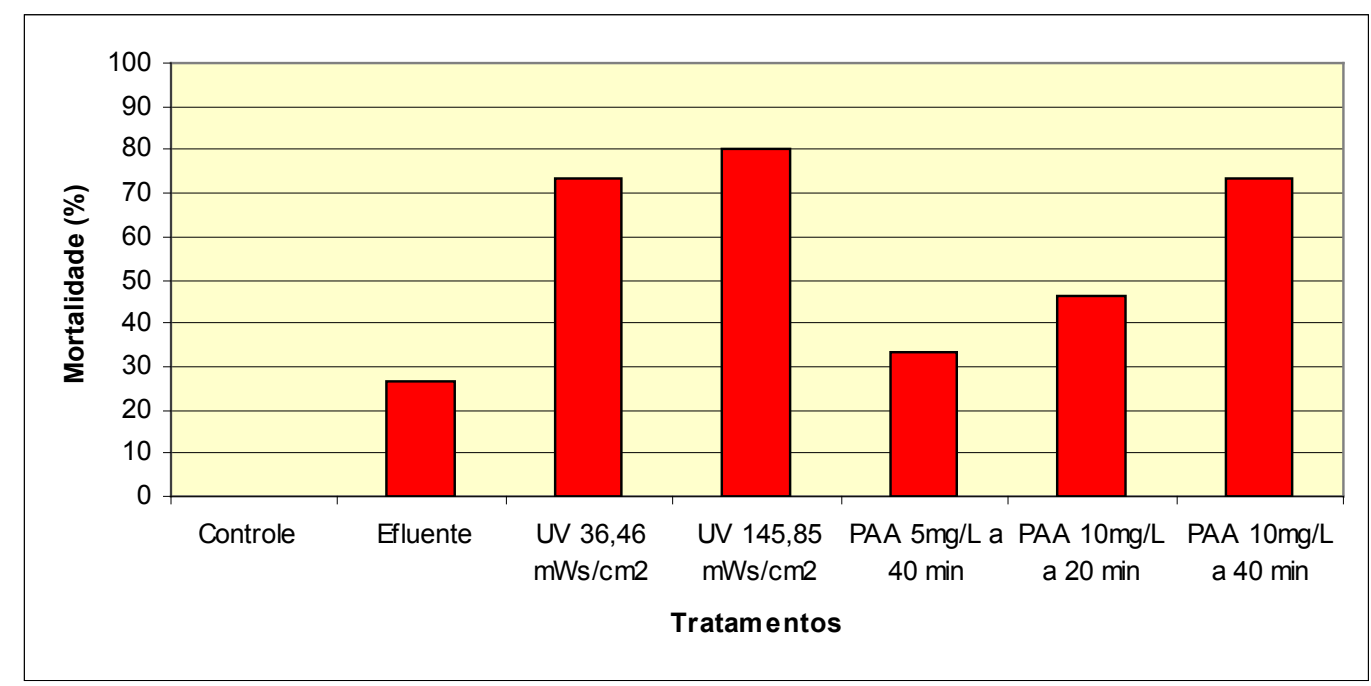

Figura 6.17. Porcentagem de mortalidade de D. rerio expostos a amostras de esgoto coletadas em 26/04/2004 antes e após desinfecção com UV e PAA.

(Tratamentos em vermelho indicam valores significativamente diferentes do controle).

Ressalta-se que a análise estatística de comparações múltiplas entre os tratamentos identificou diferença significativa entre o experimento com esgoto não desinfetado e os seguintes experimentos de desinfecção: radiação UV nas doses de 36,46 e 145,85mWs/ $\mathrm{cm}^{2}$ e ácido peracético na concentração de $10 \mathrm{mg} / \mathrm{L}$ e $40 \mathrm{~min}$. de TC. Esse resultado sugere que a toxidez do efluente ao $D$. rerio foi potencializada com a adição dos referidos agentes desinfetantes.

Nota-se que a mortalidade de $D$. rerio nos diversos tratamentos foi inversamente proporcional às concentrações de oxigênio dissolvido encontradas nas amostras no final dos testes. 
Dentre os tratamentos de desinfecção com ácido peracético, o teste onde obteve-se a maior concentração residual de PAA $(0,9898 \mathrm{mg} / \mathrm{L})$ provocou maior mortalidade nesse organismo $(73,3 \%)$.

Além disso, observou-se que a desinfecção do esgoto com radiação UV na dose recebida de $145,85 \mathrm{mWs} / \mathrm{cm}^{2}$ foi estatisticamente mais tóxica ao $D$. rerio do que a desinfecção com ácido peracético na concentração de $5 \mathrm{mg} / \mathrm{L}$.

\section{C. xanthus:}

Nos bioensaios com C. xanthus, não foi verificada diferença significativa entre o controle e os diversos tratamentos (tabela A-I.7). Logo, conclui-se que a sobrevivência desse organismo não foi prejudicada quando da sua exposição ao esgoto da ETE-Araraquara coletado em 26/04/2004, tenha sido ele desinfetado ou não.

\section{C. silvestrii:}

Com relação aos bioensaios com $C$. silvestrii, observou-se toxicidade aguda em todos os tratamentos testados, com $50 \%$ de imobilidade para o efluente não desinfetado, $100 \%$ para os tratamentos com ácido peracético e 70 e 90\% para os ensaios com radiação UV (36,46 e $145,85 \mathrm{mWs} / \mathrm{cm}^{2}$, respectivamente) (tabela A-I.8 e figura 6.18). Novamente pode-se observar potencialização da toxidez do efluente quando o mesmo é submetido à desinfecção.

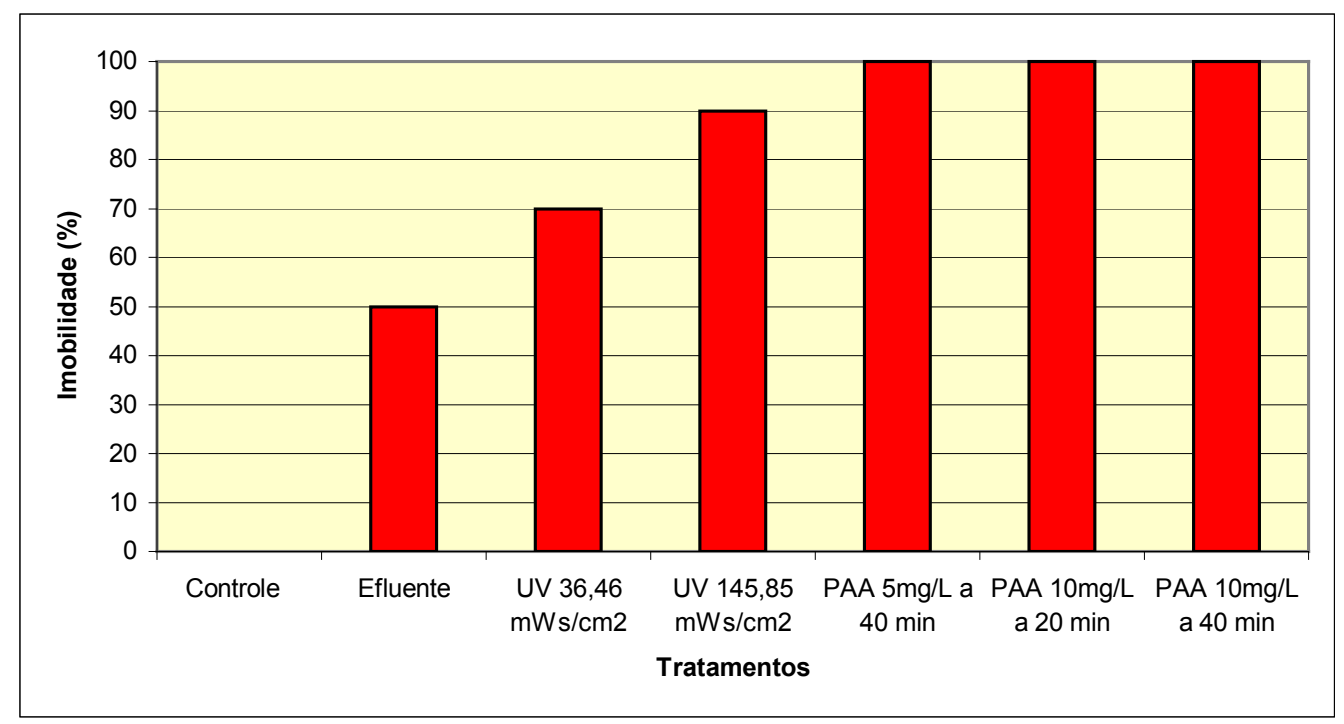

Figura 6.18. Porcentagem de imobilidade de C. silvestrii expostas a amostras de esgoto coletadas em 26/04/2004 antes e após desinfecção com UV e PAA.

(Tratamentos em vermelho indicam valores significativamente diferentes do controle). 


\section{A. cepa:}

Para A. сера, o teste estatístico de Dunnett identificou diferença significativa entre o controle e todos os tratamentos, com exceção do experimento de desinfecção com $10 \mathrm{mg} / \mathrm{L}$ de ácido peracético e 20 minutos de tempo de contato (tabela A-I.9 e figura 6.19).

Verificou-se que, dentre os tratamentos de desinfecção com ácido peracético, o teste onde obteve-se a maior concentração residual de PAA $(0,9898 \mathrm{mg} / \mathrm{L})$ provocou a maior inibição do crescimento da raiz da cebola $(50,4 \%)$.

Já com relação aos diferentes agentes de desinfecção, a concentração de $10 \mathrm{mg} / \mathrm{L}$ de ácido peracético, no tempo de contato de 20 minutos, provocou toxidez significativamente menor à $A$. cepa do que as amostras de esgoto desinfetadas com radiação UV.

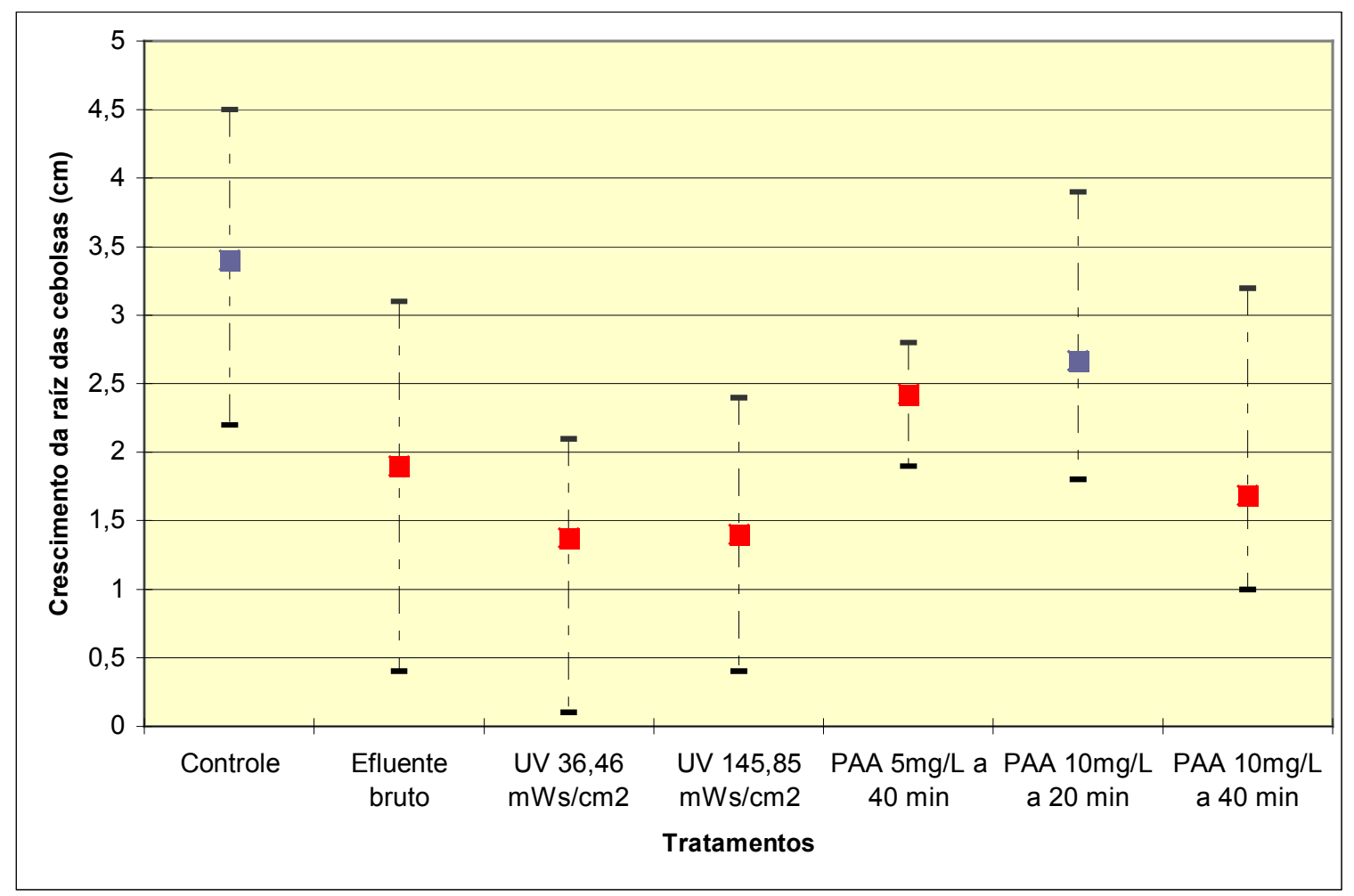

Figura 6.19. Média de crescimento e crescimento máximo e mínimo das raízes de $A$. cepa submetidas a amostras de esgoto coletadas em 26/04/2004 antes e após desinfecção com UV e PAA.

(Quadrados em vermelho indicam valores significativamente diferentes do controle).

As tabelas 6.22 e A-I.10 apresentam o resumo dos resultados dos testes de toxicidade realizados com amostras do esgoto da ETE-Araraquara coletadas em 26/04/2004 antes e após os ensaios de desinfecção. 
Tabela 6.22. Toxicidade do efluente da ETE-Araraquara coletado em 26/04/04 antes e após a desinfecção com PAA e UV e eficiência de remoção de E. coli.

\begin{tabular}{|c|c|c|c|c|c|c|c|c|}
\hline \multirow{2}{*}{ Amostras } & \multirow{2}{*}{ [PAA] ou Dr } & \multirow{2}{*}{$\begin{array}{c}\text { Residual } \\
\text { de PAA } \\
\text { (mg/L) }\end{array}$} & \multirow{2}{*}{$\begin{array}{c}\text { Eficiência } E \text {. } \\
\text { coli (\%) }\end{array}$} & \multicolumn{4}{|c|}{ Mortalidade / Imobilidade (\%) } & \multirow{2}{*}{$\begin{array}{c}\text { Inibição de } \\
\text { Crescimento } \\
(\%) \\
\text { A. Cepa }\end{array}$} \\
\hline & & & & $\begin{array}{l}D . \\
\text { similis }\end{array}$ & $\underset{\text { rerio }}{D .}$ & $\begin{array}{c}C . \\
\text { xanthus }\end{array}$ & $\begin{array}{c}C . \\
\text { silvestrii }\end{array}$ & \\
\hline Controle & & & & 5 & $\mathbf{0}$ & $\mathbf{0}$ & $\mathbf{0}$ & $\mathbf{0}$ \\
\hline Efluente & & & & $\mathbf{0}$ & 26,6 & $\mathbf{0}$ & 50 & 44,1 \\
\hline PAA & $5 \mathrm{mg} / \mathrm{L}, 40 \mathrm{~min}$ & 0,9226 & 99,812 & 50 & 33,3 & $\mathbf{0}$ & 100 & 28,7 \\
\hline PAA & $10 \mathrm{mg} / \mathrm{L}, 20 \mathrm{~min}$ & 0,9525 & 99,98 & 65 & 46,6 & $\mathbf{0}$ & 100 & 21,0 \\
\hline PAA & $10 \mathrm{mg} / \mathrm{L}, 40 \mathrm{~min}$. & 0,9898 & 99,976 & 55 & 73,3 & $\mathbf{0}$ & 100 & 50,4 \\
\hline UV & $36,46 \mathrm{mWs} / \mathrm{cm}^{2}$ & & 99,987 & $\mathbf{0}$ & 73,3 & $\mathbf{0}$ & 70 & 58,8 \\
\hline UV & $145,85 \mathrm{mWs} / \mathrm{cm}^{2}$ & & 99,926 & $\mathbf{0}$ & 80 & 10 & 90 & 59,6 \\
\hline
\end{tabular}

$\mathrm{Dr}=$ Dose recebida de radiação UV.

Valores em vermelho correspondem a amostras significativamente diferentes do controle (teste de Dunnett para $A$. cepa e de Steel Many One Rank para os outros organismos); isto é, tóxicas.

Analisando a tabela 6.22, pode-se observar que cada organismo-teste respondeu de forma diferenciada à exposição aos diversos tratamentos, o que é natural, já que espécies diferentes não são igualmente susceptíveis à mesma substância química e, muito menos, à uma mistura complexa heterogênea.

Nota-se que o ácido peracético foi tóxico a todos os organismos-teste, com exceção de $C$. xanthus, sendo que sua maior concentração aplicada, que ocasionou maior concentração residual, provocou maior toxicidade aos organismos-teste, de uma forma geral.

Com relação à radiação UV, este agente de desinfecção causou toxicidade somente quando os organismos-teste também sofreram efeitos deletérios ao efluente não desinfetado. Nesses casos, seu efeito tóxico foi superior ao do ácido peracético (exceção seja feita ao teste com C. silvestrii).

Notou-se também que quando o efluente não desinfetado mostrou-se, por si só, tóxico aos organismos-teste, sua toxidez foi potencializada com a adição dos diferentes agentes desinfetantes.

\subsubsection{Avaliação ecotoxicológica do esgoto tratado após os ensaios de desinfecção $-2^{\mathrm{a}}$ Bateria}

Os resultados dos testes de toxicidade com amostras de esgoto tratado da ETE-Araraquara coletadas em 05/07/2004 e submetidas a desinfecção com ácido peracético e radiação ultravioleta podem ser visualizados nas tabelas A-I.11 a A-I.16 (Anexo I).

\section{D. similis:}

Nos bioensaios com $D$. similis houve diferença significativa somente entre o controle e os tratamentos com ácido peracético na concentração aplicada de $10 \mathrm{mg} / \mathrm{L}$. Foi verificada 35 e 100\% de 
imobilidade dos organismos-teste nos tempos de contato de 20 e 40 minutos, respectivamente (figura 6.20). Nesses experimentos foram encontrados residuais de PAA de 0,8443 e $0,9823 \mathrm{mg} / \mathrm{L}$, respectivamente. Os outros tratamentos não causaram efeito tóxico à D. similis. (tabela A-I.11).

Também foi verificado, por meio de testes estatísticos de comparações múltiplas, que houve diferença significativa entre a amostra submetida à desinfecção com ácido peracético na concentração de $10 \mathrm{mg} / \mathrm{L}$ e tempo de contato de $40 \mathrm{~min}$. e todos os outros tratamentos.

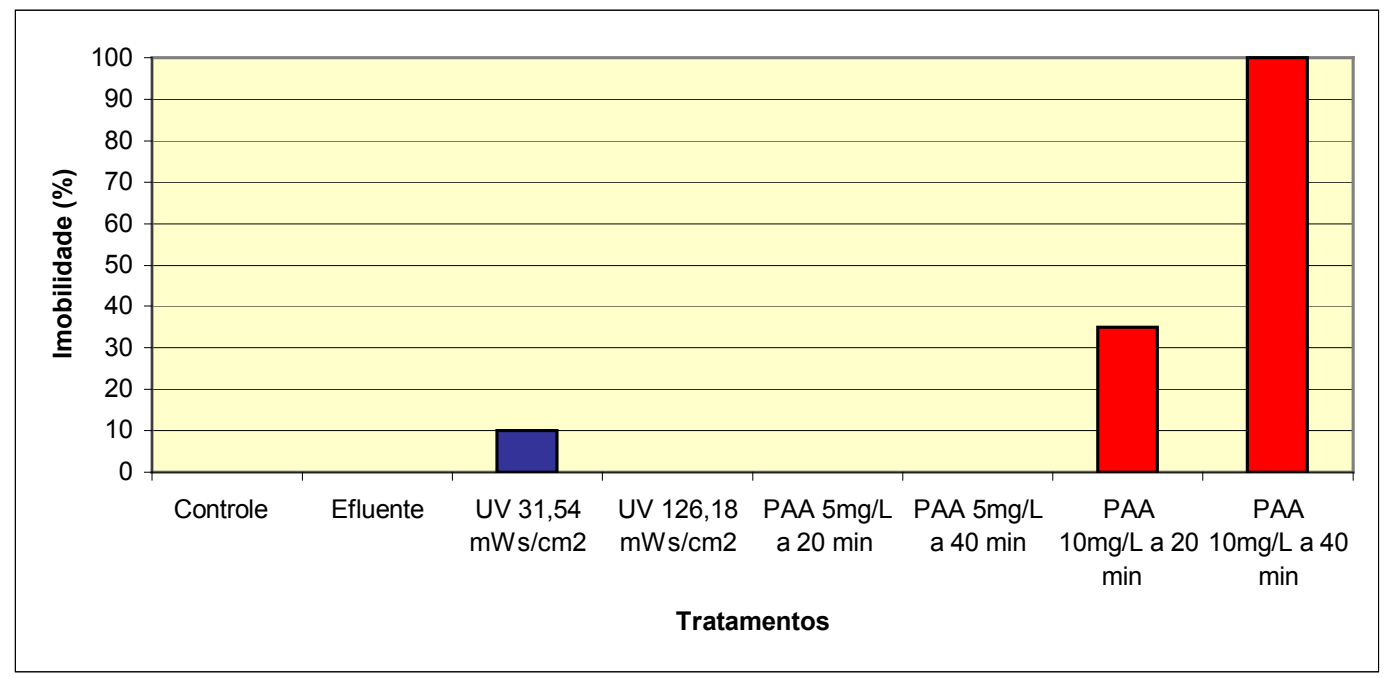

Figura 6.20. Porcentagem de imobilidade de $D$. similis expostas a amostras de esgoto coletadas em 5/7/2004 antes e após desinfecção com UV e PAA.

(Tratamentos em vermelho indicam valores significativamente diferentes do controle).

\section{D. rerio e C. xanthus:}

Nos ensaios com $D$. rerio e $C$. xanthus, não foi evidenciada toxicidade em nenhum dos tratamentos (tabelas A-I.12 e A-I.13, respectivamente).

\section{C. silvestrii:}

Em contraposição, para $C$. silvestrii, novamente foi observada toxicidade aguda em todos os experimentos, sendo verificadas porcentagens de imobilidade superiores a $90 \%$ em todos os casos (tabela A-I.14 e figura 6.21). 




Figura 6.21. Porcentagem de imobilidade de $C$. silvestrii expostas a amostras de esgoto coletadas em 5/7/2004 antes e após desinfecção com UV e PAA.

(Tratamentos em vermelho indicam valores significativamente diferentes do controle).

\section{A. cepa:}

Nos bioensaios com $A$. сеpa, foi verificada diferença significativa entre o controle e os tratamentos de desinfecção com radiação UV e PAA (10mg/L 40 min. de tempo de contato) (tabela A-I.15 e figura 6.22). No entanto, independentemente de comprovação estatística, considera-se que houve indícios de toxicidade nos outros tratamentos, uma vez que a porcentagem de inibição do crescimento da raiz nos outros experimentos com ácido peracético e com o efluente não desinfetado ficou acima de $25 \%$.

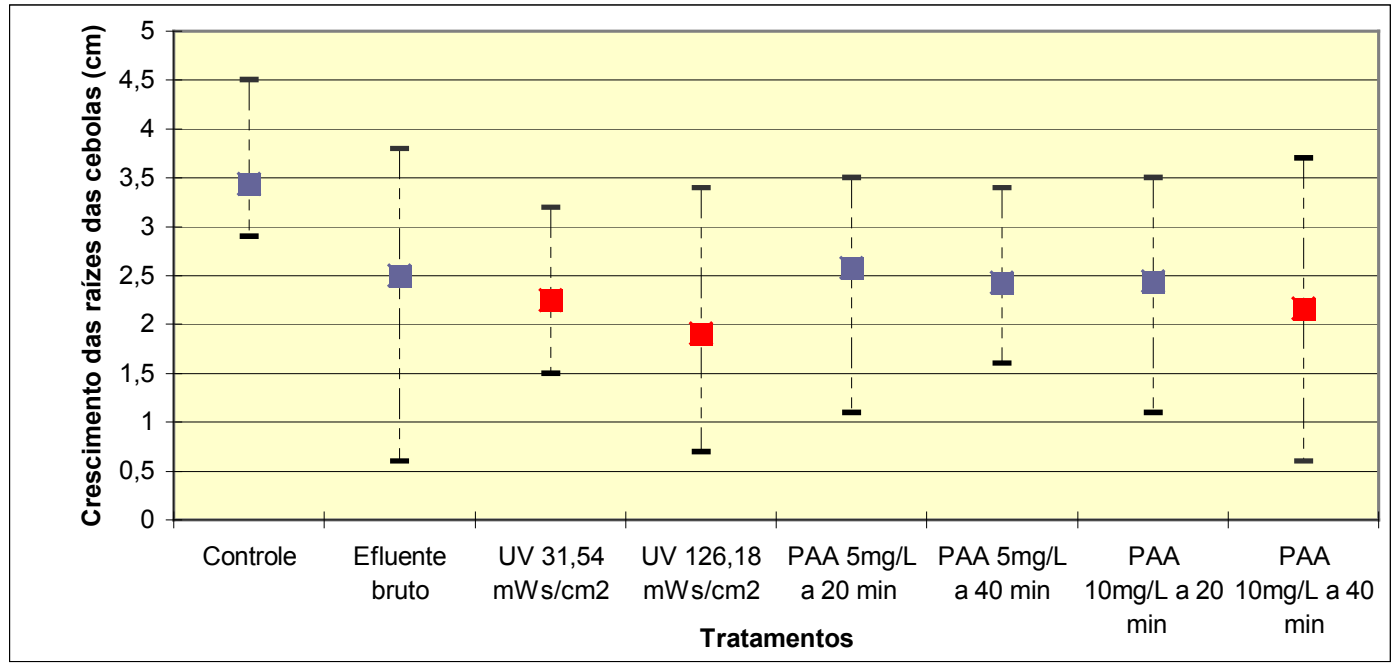

Figura 6.22. Média de crescimento e crescimento máximo e mínimo das raízes de $A$. cepa submetidas a amostras de esgoto coletadas em 05/07/2004 antes e após desinfecção com UV e PAA.

(Quadrados em vermelho indicam valores significativamente diferentes do controle). 
As tabelas 6.23 e A-I.16 apresentam o resumo dos resultados dos testes de toxicidade realizados com amostras do esgoto da ETE-Araraquara coletadas em 05/07/2004 antes e após os ensaios de desinfecção.

Nessa bateria de testes de toxicidade, o efluente não desinfetado provocou efeito deletério apenas a $C$. silvestrii, tendo sido verificado indícios de toxicidade à $A$. cepa. Como conseqüência, as desinfecções do efluente com ácido peracético e radiação UV não causaram toxicidade à $D$. rerio e os experimentos com $5 \mathrm{mg} / \mathrm{L}$ de ácido peracético não se mostraram tóxicos à $D$. similis, diferentemente do que foi observado nos bioensaios realizados na $1^{\text {a }}$ bateria, com amostras de esgoto coletadas em 26/04/2004.

Tabela 6.23. Toxicidade do efluente da ETE-Araraquara coletado em 05/07/04 antes e após a desinfecção com PAA e UV e eficiência de remoção de E. coli.

\begin{tabular}{|c|c|c|c|c|c|c|c|c|}
\hline \multirow{2}{*}{ Amostras } & \multirow{2}{*}{ [PAA] ou Dr } & \multirow{2}{*}{$\begin{array}{c}\text { Residual } \\
\text { de PAA } \\
(\mathrm{mg} / \mathrm{L})\end{array}$} & \multirow{2}{*}{$\begin{array}{l}\text { Eficiência } \\
\text { E. coli }(\%)\end{array}$} & \multicolumn{4}{|c|}{ Mortalidade / Imobilidade (\%) } & \multirow{2}{*}{$\begin{array}{c}\begin{array}{c}\text { Inibição de } \\
\text { Crescimento } \\
(\%)\end{array} \\
\text { A. Cepa }\end{array}$} \\
\hline & & & & $\begin{array}{c}\text { D. } \\
\text { similis }\end{array}$ & $\begin{array}{c}D . \\
\text { rerio }\end{array}$ & $\begin{array}{c}C . \\
\text { xanthus }\end{array}$ & $\begin{array}{c}C . \\
\text { silvestrii }\end{array}$ & \\
\hline Controle & & & & $\mathbf{0}$ & $\mathbf{0}$ & 10 & $\mathbf{0}$ & $\mathbf{0 , 0}$ \\
\hline Efluente & & & & $\mathbf{0}$ & $\mathbf{0}$ & $\mathbf{0}$ & 100 & 27,3 \\
\hline PAA & $5 \mathrm{mg} / \mathrm{L}, 20 \mathrm{~min}$. & 0,8667 & 99,901 & $\mathbf{0}$ & $\mathbf{0}$ & 10 & 90 & 25,0 \\
\hline PAA & $5 \mathrm{mg} / \mathrm{L}, 40 \mathrm{~min}$. & 0,9040 & 99,859 & $\mathbf{0}$ & 6,66 & 10 & 100 & 29,4 \\
\hline PAA & $10 \mathrm{mg} / \mathrm{L}, 20 \mathrm{~min}$ & 0,8443 & 99,999 & 35 & 6,66 & 10 & 90 & 29,1 \\
\hline PAA & $10 \mathrm{mg} / \mathrm{L}, 40 \mathrm{~min}$. & 0,9823 & 99,762 & 100 & $\mathbf{0}$ & $\mathbf{0}$ & 90 & 37,2 \\
\hline UV & $31,54 \mathrm{mWs} / \mathrm{cm}^{2}$ & & 98,720 & 10 & $\mathbf{0}$ & $\mathbf{0}$ & 90 & 34,6 \\
\hline UV & $126,18 \mathrm{mWs} / \mathrm{cm}^{2}$ & & 99,962 & $\mathbf{0}$ & $\mathbf{0}$ & 10 & 100 & 44,5 \\
\hline
\end{tabular}

$\mathrm{Dr}=$ Dose recebida de radiação UV.

Valores em vermelho correspondem a amostras significativamente diferentes do controle (teste de Dunnett para $A$. cepa e de Steel Many One Rank para os outros organismos); isto é, tóxicas.

Valores em azul correspondem a amostras onde houve indícios de toxicidade.

Novamente, notou-se potencialização da toxicidade do efluente com a adição dos agentes desinfetantes. Esse fato pôde ser observado nos ensaios com $A$. cepa, onde houve indícios de toxicidade quando esse organismo foi exposto ao efluente não desinfetado e toxicidade quando houve exposição ao efluente desinfetado com ácido peracético $(10 \mathrm{mg} / \mathrm{L}$ em 40 minutos de tempo de contato) e com radiação UV.

\subsubsection{Avaliação ecotoxicológica do esgoto tratado após os ensaios de desinfecção $-3^{\mathrm{a}}$ Bateria}

Os resultados dos testes de toxicidade com amostras de esgoto tratado da ETE-Araraquara coletadas em 17/11/2004 e submetidas a desinfecção com ácido peracético, radiação UV, ozônio e cloro podem ser visualizados nas tabelas A-I.17 a A-I.22 (Anexo I). 


\section{D. similis:}

Para $D$. similis foi verificada toxicidade somente quando o efluente foi desinfetado com ozônio e cloro. Os outros tratamentos não causaram efeito tóxico à $D$. similis. (tabela A-I.17 e figura 6.23).

Houve imobilidade de 60 e $80 \%$ dos organismos expostos ao efluente desinfetado com dose efetiva de ozônio de 29,9 e 45,15mg/L, respectivamente. Ressalta-se que as concentrações residuais de ozônio nesses experimentos foram de 1,44 e 1,56 $\mathrm{mgO}_{3} / \mathrm{L}$.

Já o cloro provocou $100 \%$ de imobilidade aos organismos-teste nas primeiras 24 horas de exposição para os tratamentos com concentrações de $7 \mathrm{mg} / \mathrm{L}$ (tempos de contato de 20 e $40 \mathrm{~min}$.) e 2,5mg/L (20 min. de tempo de contato). Para a concentração de 2,5mg/L e $40 \mathrm{~min}$. de tempo de contato, foi verificada $85 \%$ de imobilidade nas primeiras 24 horas de exposição, sendo que nas últimas 24 horas de teste, não foi evidenciado mais nenhum efeito tóxico aos organismos remanescentes. Considerando que a maior porcentagem de imobilidade coincidiu com as maiores concentrações residuais de cloro (livre e total) encontradas ao final dos ensaios de desinfecção, atribui-se a esses residuais o efeito deletério causado aos cladocera.

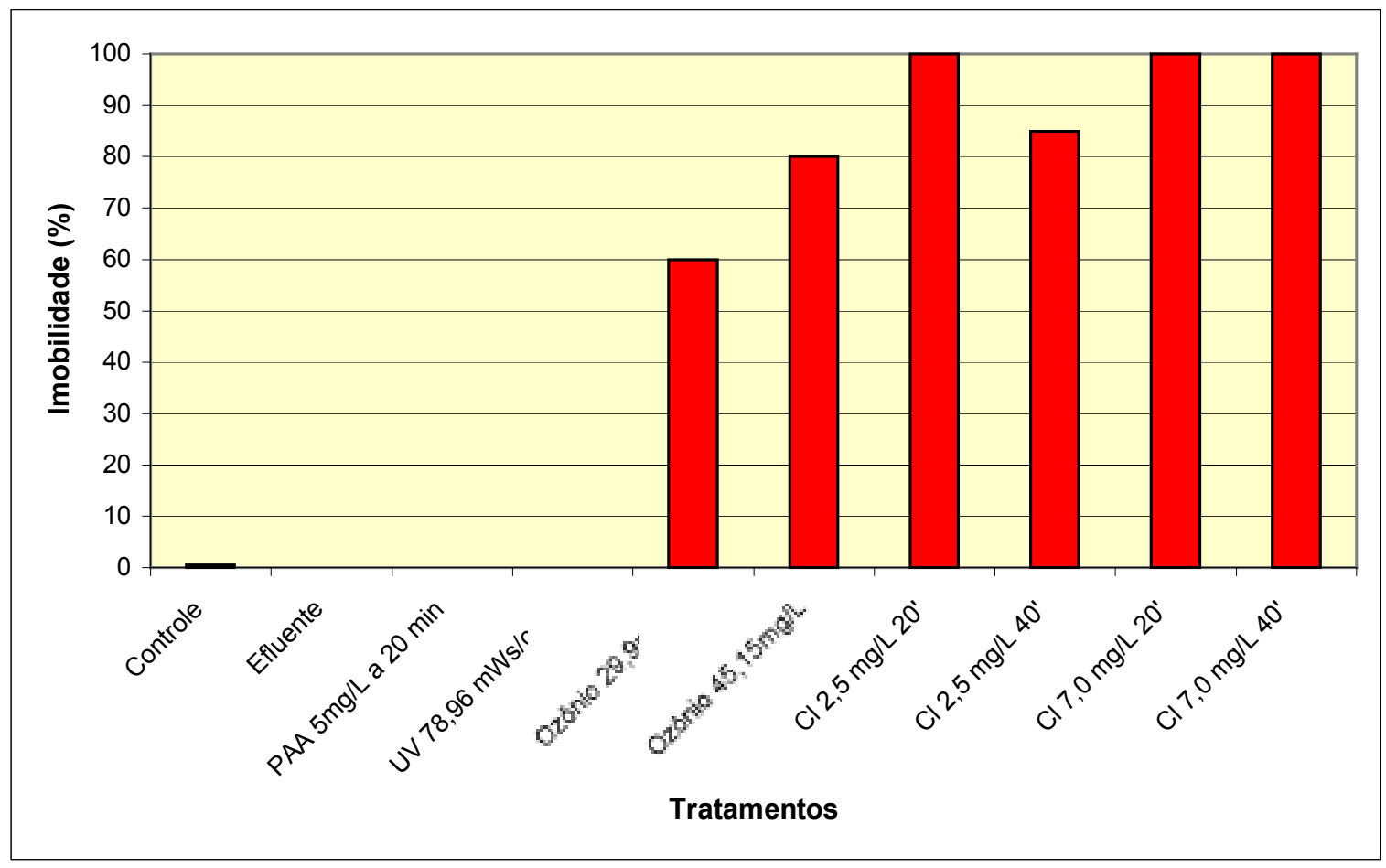

Figura 6.23. Porcentagem de imobilidade de $D$. similis expostas a amostras de esgoto coletadas em 17/11/2004 antes e após desinfecção com UV e PAA, ozônio e cloro. (Tratamentos em vermelho indicam valores significativamente diferentes do controle). 
O teste estatístico de Kruskal-Wallis evidenciou diferença significativa entre a amostra de efluente não desinfetada e os tratamentos com ozônio e cloro. Esse resultado indica que a adição desses agentes desinfetantes ao efluente, o tornou tóxico ao cladocera.

Os experimentos de desinfecção com ozônio e cloro também foram significativamente mais tóxicos à $D$. similis do que os experimentos com radiação UV e com PAA. Nesse sentido, para esse organismo, a desinfecção do efluente com radiação UV ou com PAA, nas doses ou concentrações testadas, seria o mais indicado nesse momento.

Ainda com relação aos bioensaios com $D$. similis, foi verificada diferença significativa entre o tratamento com ozônio na dose de $29,9 \mathrm{mgO}_{3} / \mathrm{L}$ e os experimentos com cloro $(7,0 \mathrm{mg} / \mathrm{L}$ a 20 e 40 min. e $2,5 \mathrm{mg} / \mathrm{L}$ a $20 \mathrm{~min}$.).

\section{D. rerio:}

Nos bioensaios com D. rerio, observou-se indícios de toxicidade para o efluente não desinfetado e toxicidade aguda (comprovada por testes estatísticos) para todos os outros tratamentos (tabela A-I.18 e figura 6.24). A mortalidade desse organismo foi superior a 50\% nos experimentos com os desinfetantes, atingindo $100 \%$ em todos os tratamentos com cloro.

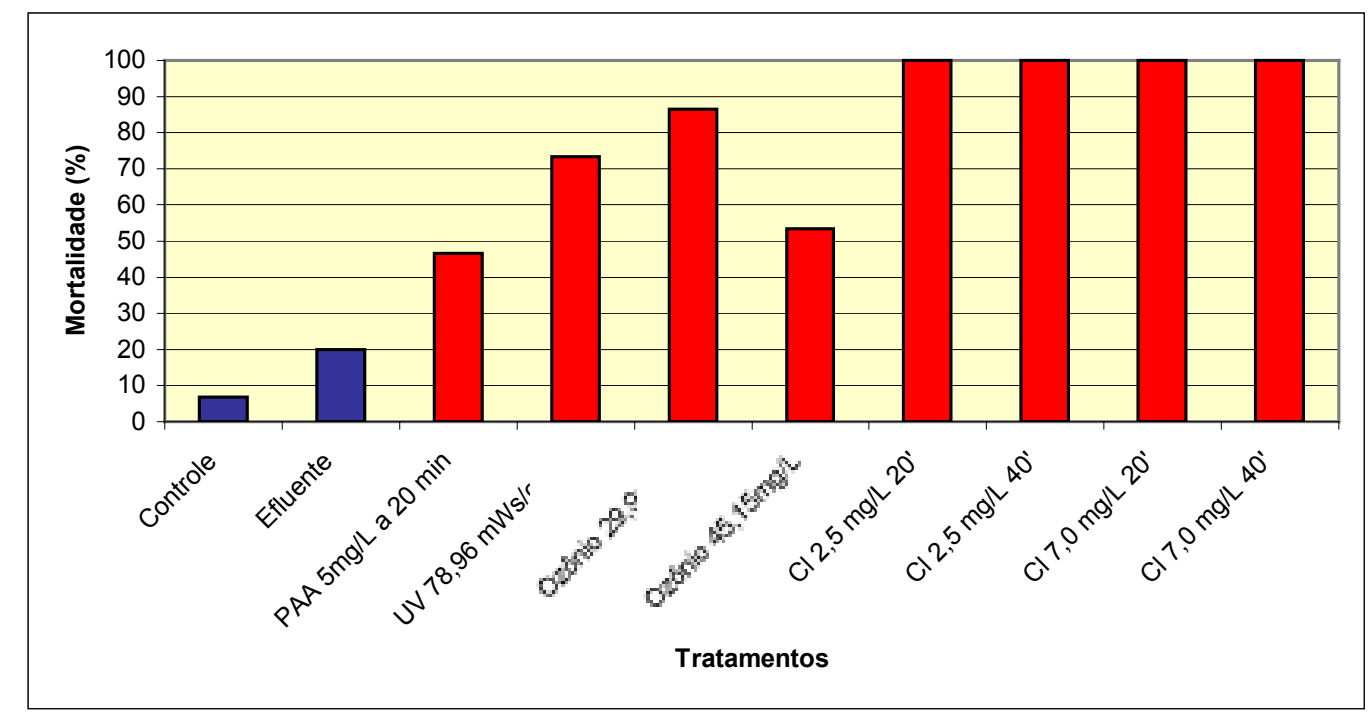

Figura 6.24. Porcentagem de mortalidade de D. rerio expostos a amostras de esgoto coletadas em 17/11/2004 antes e após desinfecção com UV e PAA, ozônio e cloro. (Tratamentos em vermelho indicam valores significativamente diferentes do controle).

Cumpre ressaltar que em todos os bioensaios com cloro foi observada mortalidade total dos organismos nas primeiras 24 horas de teste, o que não ocorreu para os outros desinfetantes. 
Verificou-se diferença significativa de toxicidade entre o esgoto não desinfetado e todos os outros tratamentos, com exceção da desinfecção com ácido peracético e ozônio (na dose de $45,15 \mathrm{mg} / \mathrm{L}$ ). Esse resultado novamente demonstra que quando o efluente, por si só, já causa efeito deletério a um organismo-teste, sua toxicidade é potencializada com a adição de desinfetantes.

Os experimentos de desinfecção com cloro também foram significativamente mais tóxicos à D. rerio do que os experimentos com ozônio $(45,15 \mathrm{mg} / \mathrm{L})$ e ácido peracético.

\section{C. xanthus:}

Para C. xanthus, pela primeira vez no estudo foi verificada diferença significativa entre o controle e os tratamentos. As amostras de efluente desinfetadas com cloro na concentração de $7 \mathrm{mg} / \mathrm{L}$ se mostraram tóxicas a esse organismo, causando mortalidade de 90 e $50 \%$ para os tempos de contato de 20 e 40 minutos, respectivamente. Os outros tratamentos não causaram efeito tóxico à esse organismo. (tabela A-I.19 e figura 6.25).

Também foi evidenciada diferença de toxicidade entre os experimentos com $7 \mathrm{mg} / \mathrm{L}$ de cloro e todos os outros tratamentos.

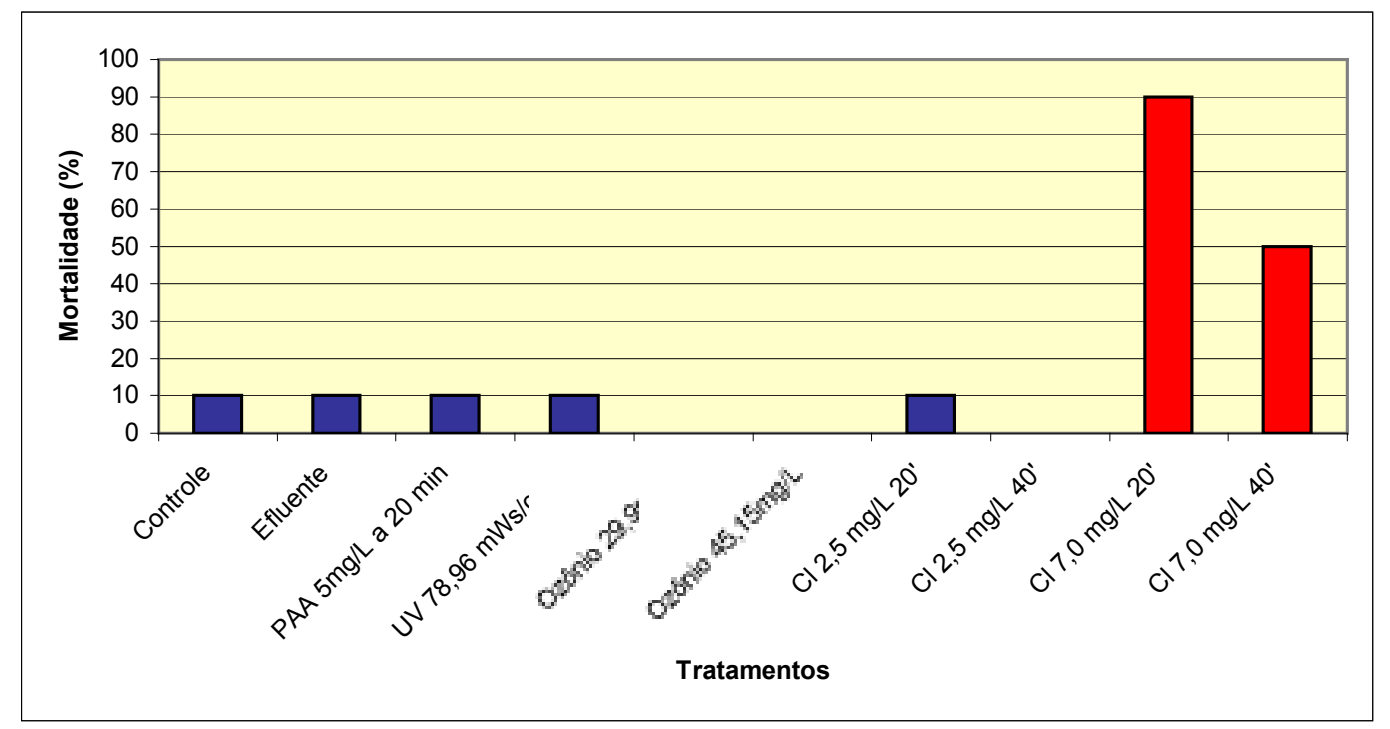

Figura 6.25. Porcentagem de mortalidade de C.xanthus expostos a amostras de esgoto coletadas em 17/11/2004 antes e após desinfecção com UV e PAA, ozônio e cloro. (Tratamentos em vermelho indicam valores significativamente diferentes do controle). 


\section{C. silvestrii:}

Para C. silvestrii, mais uma vez foi observada toxicidade aguda em todos os experimentos (tabela A-I.20 e figura 6.26). Deve-se salientar que, da mesma forma como ocorreu para D. similis e D. rerio, as diferentes concentrações de cloro provocaram $100 \%$ de imobilidade a $C$. silvestrii nas primeiras 24 horas de teste, o que não foi verificado nos outros tratamentos.

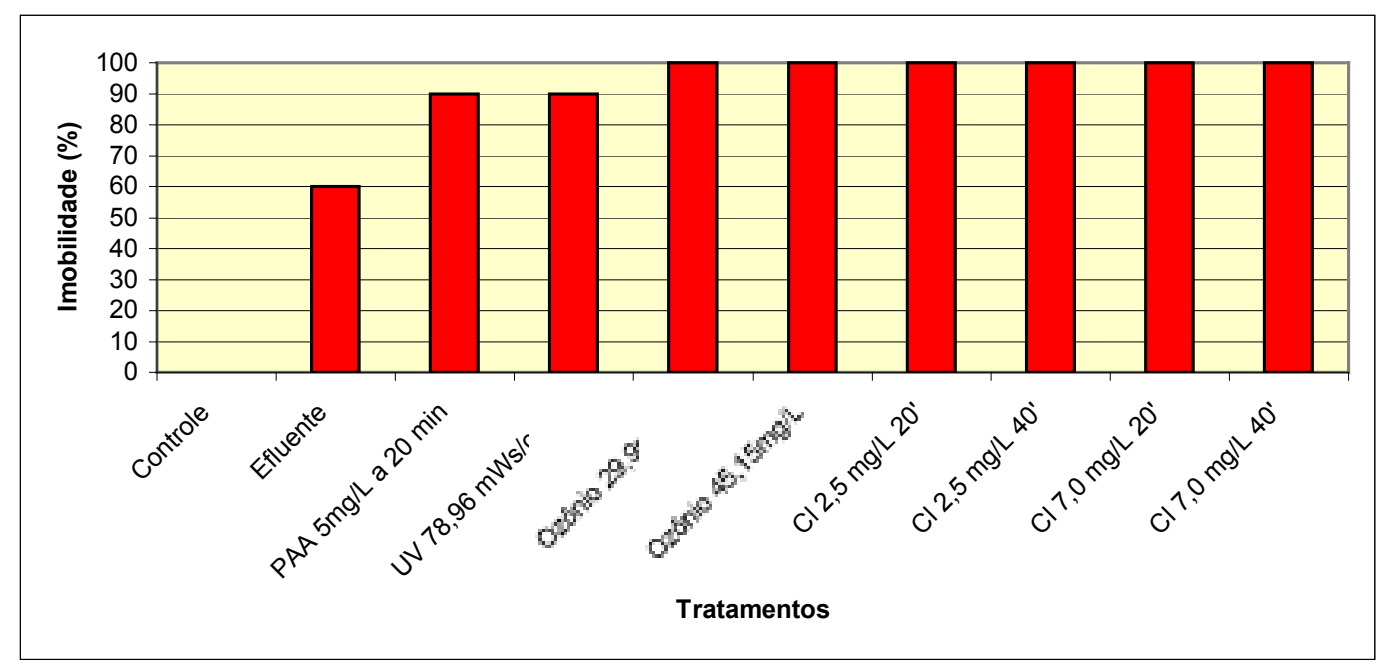

Figura 6.26. Porcentagem de imobilidade de C. silvestrii expostas a amostras de esgoto coletadas em 17/11/2004 antes e após desinfecção com UV e PAA, ozônio e cloro.

(Tratamentos em vermelho indicam valores significativamente diferentes do controle).

\section{A. cepa:}

Nos bioensaios com A. cepa, apenas foi identificada diferença significativa entre o controle e o cloro na concentração de $7,0 \mathrm{mgCl}_{2} / \mathrm{L}$ e $20 \mathrm{~min}$. de tempo de contato (tabela A-I.21 e figura 6.27). No entanto, independentemente de comprovação estatística, considera-se que houve indícios de toxicidade no tratamento com $7,0 \mathrm{mgCl}_{2} / \mathrm{L}$ e $40 \mathrm{~min}$. de tempo de contato, uma vez que a porcentagem de inibição do crescimento da raiz nesse experimento foi de $24,8 \%$. 


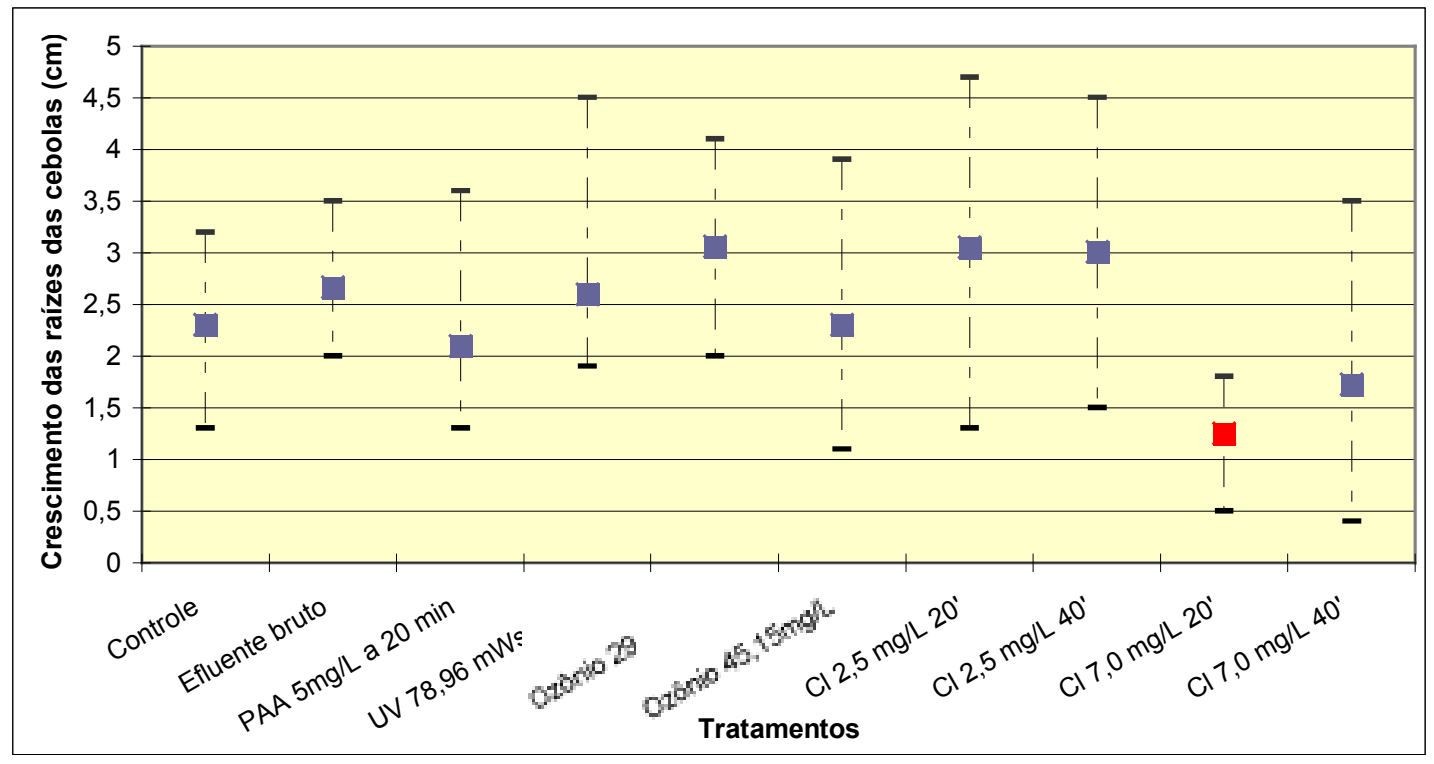

Figura 6.27. Média de crescimento e crescimento máximo e mínimo das raízes de $A$. cepa submetidas a amostras de esgoto coletadas em 17/11/2004 antes e após desinfecção com UV, PAA, ozônio e cloro.

(Quadrados em vermelho indicam valores significativamente diferentes do controle).

Outro efeito observado ao final dos bioensaios com os referidos tratamentos, foi o enturgescimento e torção das raízes das cebolas (em forma de ganchos) (figura 6.28), bem como o bifurcamento e quebra dos meristemas das raízes. Segundo Fiskesjö (1993), a manifestação desses efeitos morfológicos macroscópicos é indício de citotoxicidade.

Monarca et al. (2000) observou essas mesmas modificações morfológicas nas raízes da cebola quando expôs $A$. cepa à um efluente sanitário desinfetado com dióxido de cloro na concentração de $1,5 \mathrm{mg} / \mathrm{L}$.

Nota-se que para os outros tratamentos (com exceção do ácido peracético e do ozônio na dose de $45,15 \mathrm{mg} / \mathrm{L}$ ) houve estímulo do crescimento da raiz em relação ao controle, indicando que as amostras tornaram-se nutritivas a esse organismo.

Deve-se levar em consideração que $A$. cepa é um vegetal terrestre e, assim sendo, possui características e necessidades nutricionais distintas dos outros organismos utilizados neste estudo, o que pode justificar o seu melhor desenvolvimento em amostras mais ricas em matéria orgânica, por exemplo, do que a água utilizada no controle (água de cultivo dos cladocera).

Monarca et al. (op cit.) também verificou um maior crescimento da raiz da cebola quando expôs $A$. cepa à um efluente sanitário desinfetado com ácido peracético $(1 \mathrm{mg} / \mathrm{L})$, ozônio $(3 \mathrm{mg} / \mathrm{L})$ e radiação UV. 

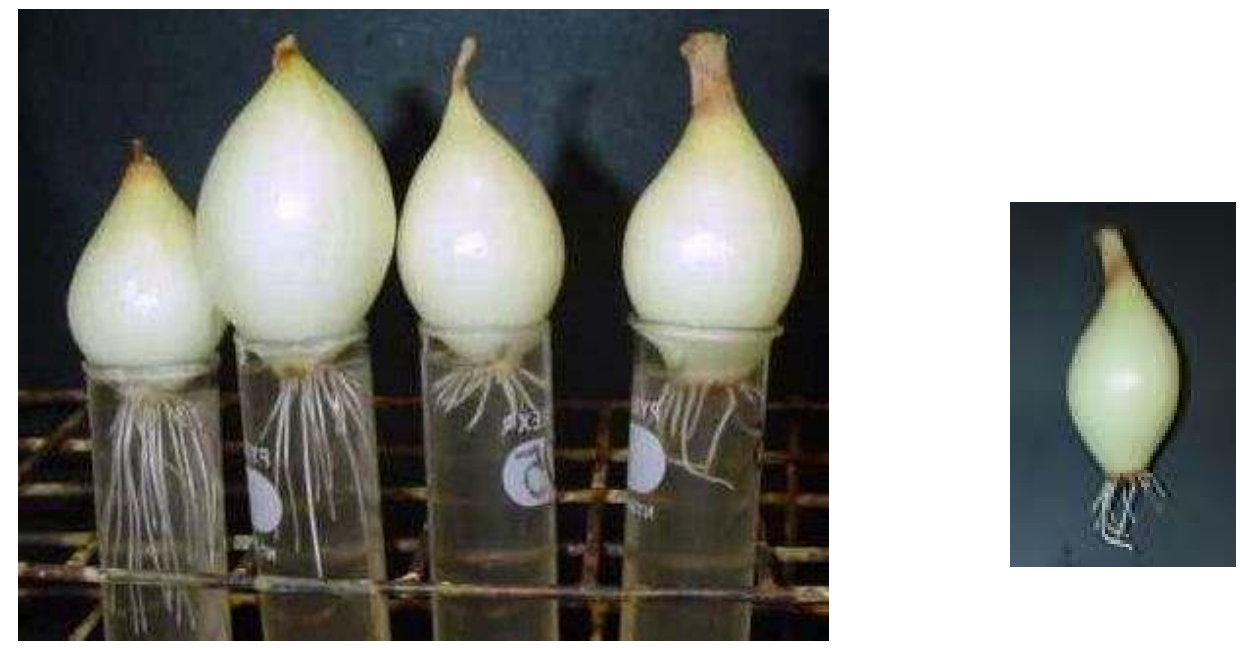

Figura 6.28. Bioensaios com A. cepa.

$\mathrm{Na}$ figura maior, os dois bulbos de cebola à esquerda representam indivíduos do controle, enquanto que os dois bulbos à direita representam indivíduos expostos à $7 \mathrm{mgCl}_{2} / \mathrm{L}$. A figura menor mostra a torção da raiz da cebola exposta a $7 \mathrm{mgCl}_{2} / \mathrm{L}$.

As tabelas 6.24 e A-I.22 apresentam o resumo dos resultados dos testes de toxicidade realizados com amostras do esgoto da ETE-Araraquara coletadas em 17/11/2004 antes e após os ensaios de desinfecção.

Tabela 6.24. Toxicidade do efluente da ETE-Araraquara coletado em 17/11/2004 antes e após a desinfecção com PAA e UV e eficiência de remoção de $E$. coli.

\begin{tabular}{|c|c|c|c|c|c|c|c|c|c|}
\hline \multirow{2}{*}{ Amostras } & \multirow{2}{*}{ [ ] ou De ou Dr } & \multirow{2}{*}{$\begin{array}{c}\text { Residua } \\
\text { I Livre } \\
\text { (mg/L) }\end{array}$} & \multirow{2}{*}{$\begin{array}{c}\text { Residual } \\
\text { Total } \\
(\mathrm{mg} / \mathrm{L})\end{array}$} & \multirow{2}{*}{$\begin{array}{l}\text { Eficiência } \\
\text { E. coli (\%) }\end{array}$} & \multicolumn{4}{|c|}{ Mortalidade / Imobilidade (\%) } & \multirow{2}{*}{$\begin{array}{c}\begin{array}{c}\text { Inibição de } \\
\text { Crescimento } \\
(\%)\end{array} \\
\text { A. Cepa }\end{array}$} \\
\hline & & & & & $\begin{array}{c}\text { D. } \\
\text { similis }\end{array}$ & $\begin{array}{c}D . \\
\text { rerio }\end{array}$ & $\begin{array}{c}C . \\
\text { xanthus }\end{array}$ & $\begin{array}{c}C . \\
\text { silvestrii }\end{array}$ & \\
\hline Controle & & & & & 0,5 & 6,66 & 10 & $\mathbf{0}$ & $\mathbf{0 , 0}$ \\
\hline Efluente & & & & & $\mathbf{0}$ & 20,0 & 10 & 60 & $-16,1$ \\
\hline PAA & $5 \mathrm{mg} / \mathrm{L}, 20 \mathrm{~min}$. & & 0,8257 & 99,992 & $\mathbf{0}$ & 46,66 & 10 & 90 & 8,7 \\
\hline UV & $78,96 \mathrm{mWs} / \mathrm{cm}^{2}$ & & & 99,282 & $\mathbf{0}$ & 73,3 & 10 & 90 & $-13,9$ \\
\hline Ozônio & $29,9 \mathrm{mg} / / \mathrm{L}$ & & 1,44 & 99,144 & 60 & 86,6 & $\mathbf{0}$ & 100 & $-33,0$ \\
\hline Ozônio & $45,15 \mathrm{mg} / / \mathrm{L}$ & & 1,56 & 99,972 & 80 & 53,33 & $\mathbf{0}$ & 100 & $\mathbf{0 , 0}$ \\
\hline Cloro & $2,5 \mathrm{mg} / \mathrm{L}, 20 \mathrm{~min}$. & 0,0365 & 0,1919 & 99,994 & 100 & 100 & 10 & 100 & $-32,6$ \\
\hline Cloro & $2,5 \mathrm{mg} / \mathrm{L}, 40 \mathrm{~min}$. & $<0,026$ & $<0,026$ & 99,997 & 85 & 100 & $\mathbf{0}$ & 100 & $-30,9$ \\
\hline Cloro & $7,0 \mathrm{mg} / \mathrm{L}, 20 \mathrm{~min}$. & 0,4871 & 2,9269 & 100 & 100 & 100 & 90 & 100 & 45,7 \\
\hline Cloro & $7,0 \mathrm{mg} / \mathrm{L}, 40 \mathrm{~min}$. & 0,1763 & 2,4193 & 100 & 100 & 100 & 50 & 100 & 24,8 \\
\hline
\end{tabular}

De $=$ Dose efetiva de Ozônio.

Dr = Dose recebida de radiação UV.

Valores em vermelho correspondem a amostras significativamente diferentes do controle (teste de Dunnett para A. cepa e de Steel Many One Rank para os outros organismos); isto é, tóxicas.

Valores em azul correspondem a amostras onde houve indícios de toxicidade.

Nesta última bateria de bioensaios foi possível comparar o potencial tóxico dos quatro agentes desinfetantes a diferentes organismos-teste. 
De uma maneira geral, para as condições experimentais estudadas, o cloro foi considerado o desinfetante mais tóxico aos organismos-alvo, sendo seguido pelo ozônio, ácido peracético e radiação UV.

O cloro, na maior concentração testada, foi tóxico a todos os organismos-teste, inclusive a C. xanthus, que é uma espécie bentônica em seu estágio larval. Esse resultado demonstra que quando essa substância é adicionada a um efluente em concentrações superiores à sua demanda, as conseqüências podem ser desastrosas à biota do corpo hídrico receptor, podendo prejudicar inclusive o bentos.

Ressalta-se que mesmo a menor concentração de cloro estudada $(2,5 \mathrm{mg} / \mathrm{L})$ proporcionou efeito tóxico a $D$. similis, $D$. rerio e $C$. silvestrii superior à provocada pelos outros agentes de desinfecção.

O cloro é um elemento extremamente reativo que reage rapidamente com substratos orgânicos e inorgânicos. Quando o substrato orgânico é parte de um organismo vivo, a reação pode provocar efeito tóxico, afetando a habilidade do organismo em se reproduzir ou metabolizar, causando disfunções genéticas ou até mesmo matando o organismo (TASK FORCE ON WASTEWATER DISINFECTION, 1996). Esses efeitos foram verificados no presente estudo.

Em um trabalho realizado pela Universidade Federal de Santa Catarina, foi observada toxicidade aguda para Daphnia magna e Vibrio fischeri expostos a efluentes de lagoas de estabilização desinfetados com dióxido de cloro, indicando que seu lançamento em corpos hídricos receptores pode provocar impactos negativos à biota local (AISSE et al., 2003).

Schifino \& De Luca (2003) apud AISSE et al. (op. cit.) analisaram a toxicidade de quatro efluentes biologicamente tratados, antes e após cloração e descloração, sobre a sobrevivência de alevinos de Tilapia nilotica. Os autores verificaram que os efluentes não desinfetados já eram tóxicos ao organismo-teste, sendo que a cloração, em todos os casos, potencializou esse efeito. Já a descloração, em alguns casos provocou a redução da toxicidade dos esgotos.

De Luca \& Cardoso (2004) também verificaram o potencial tóxico de efluentes municipais, desinfetados ou não com hipocloração seguido de descloração, em Pimephales promelas. Foram testadas duas concentrações de hipoclorito de sódio (6 e 13mg/L) em três ETEs distintas. De acordo com os autores, os esgotos não desinfetados já apresentavam toxicidade aguda ao peixe, sendo mantido esse efeito nos experimentos com desinfecção. Em um dos testes, no entanto, observou-se diminuição da toxidez do efluente após a desinfecção com $6 \mathrm{mg} / \mathrm{L}$ do oxidante, sugerindo "alguma forma de limpeza dos compostos ou sinergismo do efluente".

Com relação ao ozônio, de uma maneira geral, pode-se considerar que esse agente oxidante foi o segundo desinfetante mais tóxico aos organismos testados. As duas doses efetivas de ozônio estudadas provocaram toxicidade aguda em $D$. similis, $D$. rerio e $C$. silvestrii. 
De acordo com Lapolli et al. (2003), a toxicidade a organismos aquáticos causada pela ozonização de efluentes domésticos está associada aos subprodutos da desinfecção e não ao ozônio propriamente dito, uma vez que o ozônio não promove a formação de residual ativo persistente, pois é bastante volátil e decai espontaneamente a oxigênio em curto período de tempo. Na presença de materiais oxidantes na solução (como é o caso de esgoto doméstico), sua meia vida é bastante reduzida.

$\mathrm{Xu}$ et al. (2002), utilizando testes com MicrotoX ${ }_{\circledast}$, não verificaram toxicidade em efluentes domésticos (de nível secundário e terciário) desinfetados por ozônio nas doses efetivas que variaram entre 5 e $30 \mathrm{mg} / \mathrm{L}$. Segundo os autores, a presença de toxicidade após a ozonização geralmente está relacionada com a presença de esgoto industrial.

De forma semelhante, Paraskeva \& Graham (2005), ao aplicar doses efetivas de ozônio de 2 a $10 \mathrm{mg} / \mathrm{L}$ em um efluente secundário de esgoto doméstico também não verificaram efeitos tóxicos nos testes com Microtox ${ }_{\circledast}$.

Já Sartori (2004) observou toxicidade aguda para D. similis exposta ao efluente da ETEAraraquara desinfetado por ozônio na dose de $28 \mathrm{mg} / \mathrm{L}$ ( $40 \%$ de imobilidade). No presente estudo, a porcentagem de imobilidade de $D$. similis exposta a $29,9 \mathrm{mg} / \mathrm{L}$ de ozônio foi de $60 \%$.

Quanto ao ácido peracético, nos ensaios ora realizados, pode-se considerar que o tratamento com a maior concentração $(10 \mathrm{mg} / \mathrm{L})$ e tempo de contato (40 min.) provocou toxicidade mais pronunciada aos organismos-teste $D$. similis, C. silvestrii, D. rerio e A. cepa. Também foi verificado que a menor concentração testada de PAA $(5 \mathrm{mg} / \mathrm{L})$ foi deletéria aos referidos organismos-alvo quando suas concentrações residuais foram maiores, isto é, quando a demanda de PAA pelo efluente foi menor, o que ocorreu nas amostras coletadas em 26/04/2004.

O mecanismo de ação do ácido peracético se dá através da oxidação da membrana celular externa dos organismos, alterando suas funções osmóticas e impedindo sua atividade normal. Dentro da célula, o PAA pode oxidar enzimas essenciais, rompendo ligações sulfídricas e sulfúricas nas mesmas e degradar purinas, piridinas e nucleotídeos, provocando alterações bioquímicas e podendo levar à morte (JOLIVET-GOUGEON et al., 1996).

Os subprodutos formados pelo ácido peracético não são reconhecidos como tóxicos, uma vez que seu residual decompõe-se na água em: oxigênio, ácido acético e peróxido de hidrogênio. Sendo assim, a toxicidade a organismos aquáticos causada pela desinfecção de efluentes domésticos por esse oxidante está associada ao seu residual. Logo, para minimizar o efeito tóxico que a desinfecção de esgotos com PAA pode provocar na biota dos corpos hídricos receptores, a sua concentração aplicada não deve ultrapassar em muito a demanda do efluente por esse oxidante. Isso foi verificado no presente estudo. 
Outros estudos realizados no Brasil verificaram toxicidade para esgotos desinfetados com ácido peracético.

Gasi et al. (1995), observaram toxicidade aguda para todos os organismos-alvo utilizados (Daphnia similis, Danio rerio e Photobacterium phosphorium), sendo evidenciada uma relação direta entre a concentração aplicada de PAA (3 a 5mg/L) e o aumento da sua toxidez.

Sartori (2004), por sua vez, verificou toxicidade aguda para $D$. similis exposta ao efluente da ETE-Araraquara desinfetado por ácido peracético nas concentrações de 5 e 15mg/L (35 e 100\% de imobilidade, respectivamente). Novamente foi evidenciada uma relação direta entre a concentração aplicada de PAA e o aumento da toxidez.

Com relação à radiação UV, nas condições experimentais ora estudadas, este agente de desinfecção causou toxicidade somente para os organismos-teste que também sofreram efeitos deletérios ao efluente não desinfetado. Nesses casos, seu efeito tóxico foi superior ao do ácido peracético (exceção seja feita ao teste com C. silvestrii).

Acredita-se que a desinfecção com UV, por ser um processo físico, é ambientalmente segura, pois não forma subprodutos nem apresenta residual. No entanto, compostos que absorvem a radiação ultravioleta e apresentam alto rendimento quântico de fotólise têm alto potencial para se fotodegradar, podendo, inclusive, se transformar em compostos mais tóxicos do que os originais (efeito de foto-ativação).

Matthews et al. (1991) e Kopecky et al. (1992) observaram que vários compostos orgânicos, especialmente aqueles que contêm estruturas em anéis, como fenóis, benzenos e pirimidinas (compostos heterocíclicos nitrogenados) podem absorver radiação UV a 254nm (comprimento de onda da radiação emitida pelas lâmpadas de mercúrio utilizadas na desinfecção de água e esgoto), reagindo diretamente ou indiretamente. Na reação direta, uma molécula (à base de aminas ou fenol) pode ser modificada quimicamente via absorção direta de radiação UV. Já na reação indireta, a radiação é absorvida por espécies químicas foto-sensíveis (tais como íons nitrito/nitrato e compostos húmicos), produzindo radicais capazes de reagir com outras substâncias orgânicas.

Gjessing \& Källqvist (1991) conduziram experimentos de desinfecção com radiação UV em água superficial contendo substâncias húmicas. Os resultados mostraram que a irradiação provocou alterações na composição química da água (acidificação) e inibição do crescimento da alga Selenastrum capricornutum conforme houve o incremento da dose aplicada. De acordo com os autores, esse resultado pode ser explicado pelas interações fóton-iniciadas de substâncias húmicas e outras substâncias químicas presentes água, resultando na formação de reagentes oxidantes, tais como os radicais $\mathrm{OH}^{-}$; estes, por sua vez, oxidaram a matéria orgânica por abstração de hidrogênio.

Paraskeva \& Graham (2005) estudaram o efeito da radiação UV em um efluente secundário de esgoto doméstico. Nas doses testadas, as quais variaram entre 8,0 a $500 \mathrm{mWs} / \mathrm{cm}^{2}$, não foram 
verificados efeitos tóxicos para o método utilizado (Microtox ${ }_{\circledast}$ ). Deve-se ressaltar, no entanto, que o efluente não desinfetado não provocou toxicidade ao organismo utilizado.

Para $D$. similis, neste estudo foi observada a seguinte ordem decrescente de toxicidade dos desinfetantes: cloro > ozônio > ácido peracético, sendo que a radiação UV não provocou toxicidade em nenhum dos bioensaios realizados. Dessa forma, conclui-se que, para esse organismo, o melhor agente desinfetante a ser utilizado seria a radiação UV, de forma a garantir a melhor qualidade do efluente.

Para C. silvestrii, o lançamento do efluente não desinfetado no corpo hídrico receptor, por si só já causaria impacto na sua sobrevivência. No entanto, os dados obtidos neste estudo levam a crer que os desinfetantes provocaram potencialização do efeito tóxico do esgoto, sendo verificada a seguinte ordem decrescente de toxicidade: cloro > ozônio > ácido peracético > radiação UV. Devese lembrar que os bioensaios com $C$. silvestrii foram originalmente desenhados para findarem após o período de 7 dias (teste crônico), porém, como em nenhum dos experimentos os organismos sobreviveram após 96 horas de exposição, optou-se por apresentar os resultados obtidos no período de 48 horas de teste.

Para D. rerio, verificaram-se duas situações distintas. Quando o efluente causou efeito deletério a esse organismo, foi verificada a seguinte ordem decrescente de toxicidade aguda para os tratamentos: cloro > ozônio > radiação UV > ácido peracético > efluente não desinfetado. Porém, quando o efluente não provocou toxicidade ao peixe, a radiação UV e o ácido peracético não se mostraram prejudiciais a esse organismo.

Deve-se considerar que os bioensaios com $D$. rerio foram realizados em sistema semiestático sem fornecimento de aeração, o que pode ter influenciado nos experimentos, em especial nos testes com radiação UV, já que as menores concentrações de oxigênio dissolvido ao final dos bioensaios (inferiores a $4,0 \mathrm{mgO}_{2} / \mathrm{L}$ ) foram encontradas para as amostras desinfetadas com radiação UV em que se observou toxicidade para o peixe.

Resultado similar foi encontrado por Blatchley III et al (1997), que analisaram a toxicidade de efluentes de esgoto municipal de sete estações de tratamento antes e após a desinfecção com cloração/descloração, ozonização e radiação UV, utilizando Ceriodaphnia dubia como organismoteste. Para quatro dos efluentes estudados, quando os mesmos não provocaram toxicidade ao organismo-alvo, também não foi verificado efeito deletério em função de sua desinfecção. Porém, quando esses efluentes apresentavam toxicidade, a desinfecção usualmente resultou em um aumento da toxicidade, com uma tendência geral de cloração/descloração > ozonização > radiação UV.

Para os outros três efluentes estudados pelos pesquisadores, foi verificado que quando os mesmos não causavam toxicidade, a radiação UV também não era tóxica, porém a desinfecção com 
cloração/descloração e ozonização se mostrava deletéria ao organismo-teste. Mas, quando os efluentes apresentavam toxicidade, a cloração/descloração e ozonização provocavam um leve aumento da mortalidade de C. dubia e a irradiação UV provocava a maior porcentagem de mortalidade encontrada. Deve-se ressaltar que esses efluentes eram compostos não somente de esgoto doméstico, mas também de esgoto industrial.

Os bioensaios com A. cepa seguiram o mesmo comportamento dos testes com D. rerio, considerando os desinfetantes ácido peracético e radiação UV. Quando o efluente mostrou-se tóxico, foi verificada a seguinte ordem decrescente de toxicidade para os desinfetantes: radiação UV $>$ ácido peracético. Porém, quando o efluente não provocou efeito adverso à cebola, a radiação UV e o ácido peracético também não se mostraram tóxicos a esse organismo.

O cloro, na maior concentração estudada, certamente provocou os maiores efeitos adversos à cebola, uma vez que, além de ter sido verificada grande porcentagem de inibição do crescimento de sua raiz nesse tratamento, foram identificadas alterações morfológicas nas raízes (torções em forma de gancho, enturgescimento, bifurcamento e quebra dos meristemas), as quais indicam efeito citotóxico.

Já o ozônio (nas doses testadas) e o cloro (na concentração de 2,5mg/L) não prejudicaram o crescimento da raiz da cebola.

Monarca et al. (2000) estudaram a influência dos desinfetantes ozônio (2,5 e 3mg/L), ácido peracético $(1 \mathrm{mg} / \mathrm{L})$, radiação UV $\left(\mathrm{I}_{\mathrm{m}}\right.$ de 5,6 a $9,7 \mathrm{~mW} / \mathrm{cm}^{2}$ e tempos de contato de 4 a $11 \mathrm{~s}$.) e dióxido de cloro $(1,2$ e $1,5 \mathrm{mg} / \mathrm{L})$ na formação de compostos mutagênicos e tóxicos em águas residuárias urbanas. Para avaliar a mutagenicidade dos tratamentos, foi usado o teste de Ames com Salmonella typhimurium; para detectar danos no DNA, foram usados os testes de genotoxicidade (testes de micronúcleo) com as plantas Allium cepa e Tradescantia; e para verificar o efeito tóxico das amostras, foi empregada a bactéria marinha Vibrio fischeri em ensaios de bioluminescência.

Os autores verificaram a seguinte ordem decrescente de mutagenicidade nos tratamentos: dióxido de cloro > ozônio > ácido peracético, sendo que para a radiação UV e para o esgoto não desinfetado não foi identificado esse efeito deletério a partir do teste de Ames. Para as plantas, foi observado efeito genotóxico apenas para o ácido peracético no teste com $A$. cepa. Já para $V$. fischeri, foi evidenciada a seguinte ordem decrescente de toxicidade nos tratamentos: dióxido de cloro $>$ ozônio $>$ ácido peracético $>$ efluente não desinfetado $>$ radiação UV. Cabe observar que quando foi identificada toxicidade para a $S$. typhimurium na amostra de esgoto não desinfetada, todos os outros tratamentos de desinfecção também se mostraram tóxicos a essa bactéria, inclusive a radiação UV. 


\subsection{Bioensaios de Toxicidade com Cloro, Ácido Peracético e Radiação Ultravioleta}

Além dos bioensaios com amostras de esgoto desinfetado, também foram realizados testes de toxicidade com hipoclorito de sódio, ácido peracético e radiação ultravioleta, isoladamente, a fim de avaliar a sensibilidade dos organismos-teste a diferentes concentrações (ou doses, no caso da radiação ultravioleta) dos referidos agentes de desinfecção.

As concentrações de ácido peracético e de cloro testadas foram preparadas utilizando as devidas proporções dos respectivos oxidantes e água de diluição. A água de diluição consistiu na água reconstituída utilizada nos cultivos ou na manutenção dos organismos em laboratório.

Já para obter as diferentes dosagens de radiação ultravioleta, a água reconstituída foi submetida à uma intensidade de energia radiante constante (6 lâmpadas ligadas), porém a tempos de irradiação distintas.

Não houve possibilidade de determinar a sensibilidade dos organismos-teste ao ozônio devido a dificuldades em estabelecer baixas dosagens desse gás na água reconstituída. Cumpre observar que, embora a escala do rotâmetro permitisse selecionar a vazão de gás entre os limites de 0 e $400 \mathrm{~L} / \mathrm{h}$, na prática, para vazões inferiores a $15 \mathrm{~L} / \mathrm{h}$, o aparelho mostrou-se pouco preciso, sofrendo oscilações periódicas e dificultando seu ajuste.

\subsubsection{Bioensaios de Toxicidade com Ácido Peracético}

Neste estudo foram realizados diversos testes de toxicidade para determinar a CE50 (ou CL50) dos organismos-teste ao ácido peracético.

Inicialmente foram conduzidos ensaios preliminares com a finalidade de estabelecer a faixa de concentração tóxica em que já se observava o efeito sobre os organismos num intervalo delimitado pela menor concentração que causa $100 \%$ de mortalidade/imobilidade e a concentração mais alta em que não se observa mortalidade/imobilidade dos organismos.

Posteriormente, foram realizados os ensaios definitivos com uma série de concentrações de ácido peracético compreendidos na faixa acima mencionada.

Como resultado desses testes, foi possível calcular as CE50 ou CL50 dos diferentes organismos-teste ao ácido peracético (tabela 6.25). 
Tabela 6.25. Valores das CE50 ou CL50 de cada organismo-teste obtidos a partir dos ensaios de toxicidade com ácido peracético, seus respectivos intervalos de confiança e coeficientes de variação.

\begin{tabular}{|lcccc|}
\hline Organismo-Teste & Duração (h) & CE50 ou CL50 (mg/L) & IC (mg/L) & CV (\%) \\
\hline D. similis & 48 & 0,2834 & NC & 3,45 \\
C. silvestrii & 48 & 0,3713 & NC & 24,67 \\
D. rerio & 96 & 2,8259 & 2,72 a 2,93 & - \\
C. xanthus & 96 & 3,999 & $\mathrm{NC}$ & - \\
A. cepa & 72 & 8,7851 & $\mathrm{NC}$ & - \\
$\mathrm{NC}=$ Não calculável & & &
\end{tabular}

A partir da tabela 6.25 foi possível observar a seguinte ordem decrescente de sensibilidade dos organismos-teste ao ácido peracético: D. similis $>C$. silvestrii $>>$ D. rerio $>C$. xanthus $>A$. cepa. Logo, o organismo mais resistente a esse oxidante foi a cebola, ao passo que os mais sensíveis foram os cladocera.

As concentrações de ácido peracético necessárias para causar efeito tóxico agudo a 50\% dos Cladocera, nas condições de testes laboratoriais $(0,28$ e $0,37 \mathrm{mgPAA} / \mathrm{L}$ para a $D$. similis e $C$. silvestrii, respectivamente) foram bastante inferiores às concentrações residuais de PAA encontradas nas amostras de efluente após as desinfecções (de 0,83 a 0,99mgPAA/L). Mesmo assim, os cladocera se mostraram mais resistentes às amostras de esgoto desinfetado com PAA do que às diluições desse oxidante em água reconstituída. Isso pode ser justificado pela grande demanda de PPA existente no esgoto sanitário (em função da grande concentração de matéria orgânica) em contraposição à baixa demanda desse oxidante na água reconstituída, o que proporcionou a ação direta do desinfetante nos organismos-teste.

Em contrapartida, para os outros três organismos, as CE50 (ou CL50) obtidas para o ácido peracético diluído em água reconstituída foram bastante superiores aos seus residuais encontrados nas amostras de efluente após as desinfecções.

Para C. xanthus houve coerência entre o valor de CE50 encontrado nos testes de toxicidade com água reconstituída e os resultados dos bioensaios com amostras de efluente desinfetados. Isto é, os residuais de PAA no esgoto de fato estavam muito abaixo do valor necessário para causar efeito deletério a esse organismo.

Para $D$. rerio e $A$. cepa, quando o efluente não causou toxicidade a esses organismos, também foi verificada coerência entre o valor de CE50 encontrado nos testes de toxicidade com água reconstituída e os resultados dos bioensaios com amostras de efluente desinfetados, demonstrando que, de fato, as concentrações residuais encontradas no efluente se mostravam bem 
abaixo do necessário para causar toxicidade aos organismos. Porém, quando o efluente não desinfetado já causava efeito deletério a esses organismos, mesmo concentrações residuais de ácido peracético bastante inferiores às respectivas CE50 (ou CL50) ocasionaram aumento da sua toxicidade, indicando que o efeito tóxico do esgoto não foi função somente do residual de PAA encontrado. Certamente ocorreram interações entre o efluente e o desinfetante que provocaram um aumento da toxicidade do esgoto.

\subsubsection{Bioensaios de Toxicidade com Radiação UV}

Os testes de toxicidade com radiação UV foram realizados mantendo a intensidade de energia radiante constante (6 lâmpadas ligadas) e alterando os tempos de irradiação (15, 30 e 120 segundos). Considerando que a absorbância a $254 \mathrm{~nm}$ da água reconstituída foi de 0,015 , as doses de radiação UV recebidas foram de 78,31, 156,63 e 313,26mWs $/ \mathrm{cm}^{2}$.

Apesar da grande amplitude das doses de UV utilizadas nos bioensaios, não foi verificada mortalidade ou imobilidade a nenhum organismo-alvo. De fato, ao final dos testes, os organismos mostraram-se saudáveis. Esse resultado era esperado, uma vez que a radiação UV é um método de desinfecção físico que não apresenta residual. Ademais, devido à composição química da água reconstituída, havia pouca probabilidade de ser observado algum efeito de foto-ativação causado pela radiação UV nestes testes.

Considerando que nos bioensaios realizados com amostras de esgoto desinfetado com UV este agente de desinfecção causou toxicidade somente para os organismos-teste que também sofreram efeitos deletérios ao efluente não desinfetado e que, nesses casos, houve potencialização da toxidez do efluente, acredita-se que isso pode ter ocorrido pela presença no esgoto de compostos capazes de absorver a radiação UV com alto potencial para se fotodegradar. Esses compostos podem ter sofrido foto-ativação e ter se transformado em compostos mais tóxicos do que os originais.

\subsubsection{Bioensaios de Toxicidade com Cloro}

De forma análoga aos testes de toxicidade realizados com ácido peracético, foram conduzidos bioensaios com hipoclorito de sódio com o objetivo de tentar determinar a CE50 (ou CL50) dos organismos-alvo a esse oxidante.

Os resultados desses testes podem ser visualizados na tabela 6.26. 
Tabela 6.26. Valores das CE50 ou CL50 de cada organismo-teste obtidos a partir dos ensaios de toxicidade com cloro (hipoclorito de sódio) e seus respectivos intervalos de confiança.

\begin{tabular}{|lccc|}
\hline \multicolumn{1}{|c}{ Organismos-teste } & Duração $(\mathbf{h})$ & CE50 ou CL50 $(\mathbf{m g} / \mathbf{L})$ & IC $(\mathbf{m g} / \mathbf{L})$ \\
\hline D. similis & 48 & 0,0245 & 0,02 a 0,03 \\
C. silvestrii & 48 & 0,0255 & 0,02 a 0,03 \\
D. rerio & 96 & 0,7491 & 0,59 a 0,95 \\
C. xanthus & 96 & 2,8286 & 2,48 a 3,23 \\
A. cepa & 72 & 5,28 & $\mathrm{NC}$ \\
$\mathrm{NC}=$ Não calculável & & &
\end{tabular}

Para o cloro, também foi possível verificar a mesma ordem decrescente de sensibilidade dos organismos-teste observada para o ácido peracético, isto é: $D$. similis $>C$. silvestrii $>D$. rerio $>>$ C. xanthus $>$ A. cepa. Logo, o organismo mais resistente ao cloro também foi a cebola, ao passo que os mais sensíveis novamente foram os cladocera.

Comparando os testes de toxicidade realizados com os dois oxidantes (ácido peracético e cloro) observou-se que o cloro foi mais tóxico a todos os organismos-teste do que o ácido peracético, já que os valores das CE50 (ou CL50) foram menores para o cloro. Esse mesmo resultado também foi observado nos bioensaios com amostras de esgoto desinfetadas com cloro e ácido peracético, considerando os respectivos residuais encontrados após os ensaios de desinfecção.

As concentrações de cloro livre necessárias para causar efeito tóxico agudo a $50 \%$ dos Cladocera, nas condições de testes laboratoriais $\left(0,024\right.$ e $0,025 \mathrm{mgCl}_{2} / \mathrm{L}$ para a $D$. similis e $C$. silvestrii, respectivamente) foram, em geral, inferiores às concentrações residuais de cloro livre encontradas nas amostras de efluente após as desinfecções. Sendo assim, supõe-se que a toxicidade aguda encontrada para os cladocera nesses bioensaios foi em função das concentrações residuais de cloro encontradas nas amostras de esgoto desinfetadas.

Para os outros três organismos, as CE50 (ou CL50) obtidas para o cloro livre foram superiores aos seus residuais encontrados nas amostras de efluente após as desinfecções.

Para D. rerio, foi observada alta toxicidade do esgoto desinfetado com cloro apesar da concentrações residuais de cloro livre terem se mostrado inferiores à sua CL50, indicando que o efeito tóxico do esgoto não foi função somente do residual de cloro encontrado.

Para C. xanthus e A. cepa, foi observada toxicidade do esgoto desinfetado com cloro apenas onde foram encontradas as maiores concentrações residuais de cloro livre. Mesmo assim, os valores de seus residuais foram inferiores às respectivas CE50 ou CL50 encontrada para os organismos neste estudo. Certamente ocorreram interações entre o efluente e o desinfetante que provocaram um 
aumento da toxicidade do esgoto. Deve-se lembrar que, neste estudo, foi verificada formação de trihalometanos no efluente após sua desinfecção com cloro. Provavelmente também houve formação de outros compostos organoclorados subprodutos da cloração (ácidos haloacéticos, haloacetonitrilos, cloropicrin, clorofenóis, cloropropanonas e outros aromáticos clorados) que são potencialmente cancerígenos, mutagênicos e que podem ser bioacumulados nas cadeias tróficas.

\subsection{Testes de Sensibilidade a Substâncias de Referência}

A sensibilidade dos organismos-teste utilizados neste estudo foi avaliada por meio de ensaios com substâncias de referência pré-determinadas, com o objetivo de averiguar a qualidade e homogeneidade das culturas ao longo de diferentes gerações ou provenientes de diferentes lotes.

As características gerais dos testes de sensibilidade realizados com os organismos-teste neste estudo foram apresentadas na tabela 5.5 (tópico 5.6.7).

As faixas de sensibilidade para cada organismo-teste foram determinadas a partir das médias de CL50 (ou CE50) \pm 2 desvios-padrão dos resultados de testes de sensibilidade pretéritos.

É importante lembrar que os limites de aceitação dos resultados devem estar compreendidos nas faixas de sensibilidade, caso contrário, os organismos não devem ser utilizados em bioensaios ecotoxicológicos.

Para D. similis, a faixa de sensibilidade ao dicromato de potássio, calculada a partir dos testes de sensibilidade realizados ao longo do desenvolvimento deste estudo, foi de 0,033 a 0,065mg/L (figura 6.29).

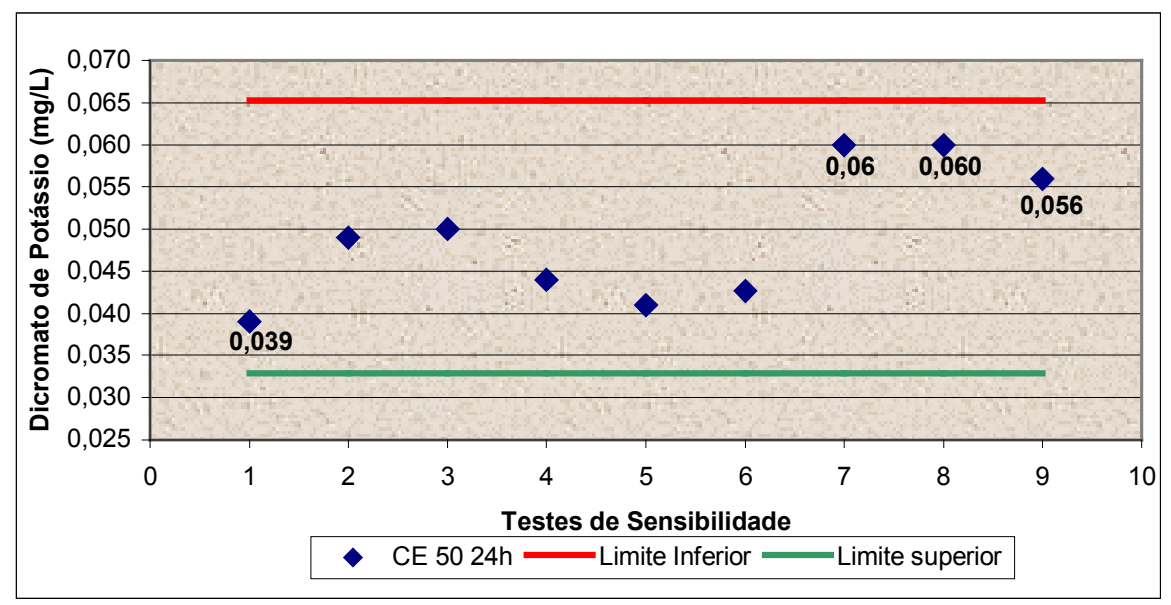

Figura 6.29. Faixa de sensibilidade de Daphnia similis ao Dicromato de Potássio ao longo do desenvolvimento do estudo. 
Os valores de CE50-24h que aparecem em destaque na figura 6.29 foram obtidos em testes de sensibilidade conduzidos nos mesmos meses em que foram realizados os bioensaios com amostras de esgoto. Percebe-se que esses valores se encontram dentro da faixa aceitável de sensibilidade dos organismos.

Para D. rerio, foi encontrada a faixa de sensibilidade de 109,81 a $163,31 \mathrm{mg} / \mathrm{L}$ de dicromato de potássio, conforme pode ser observado na figura 6.30 .

Os valores de CL50-96h apresentados na figura 6.30 foram obtidos em testes de sensibilidade conduzidos nos mesmos meses em que foram realizados os bioensaios com amostras de esgoto. Percebe-se que esses valores se encontram dentro da faixa aceitável de sensibilidade dos organismos, indicando a qualidade do ensaio ecotoxicológico.

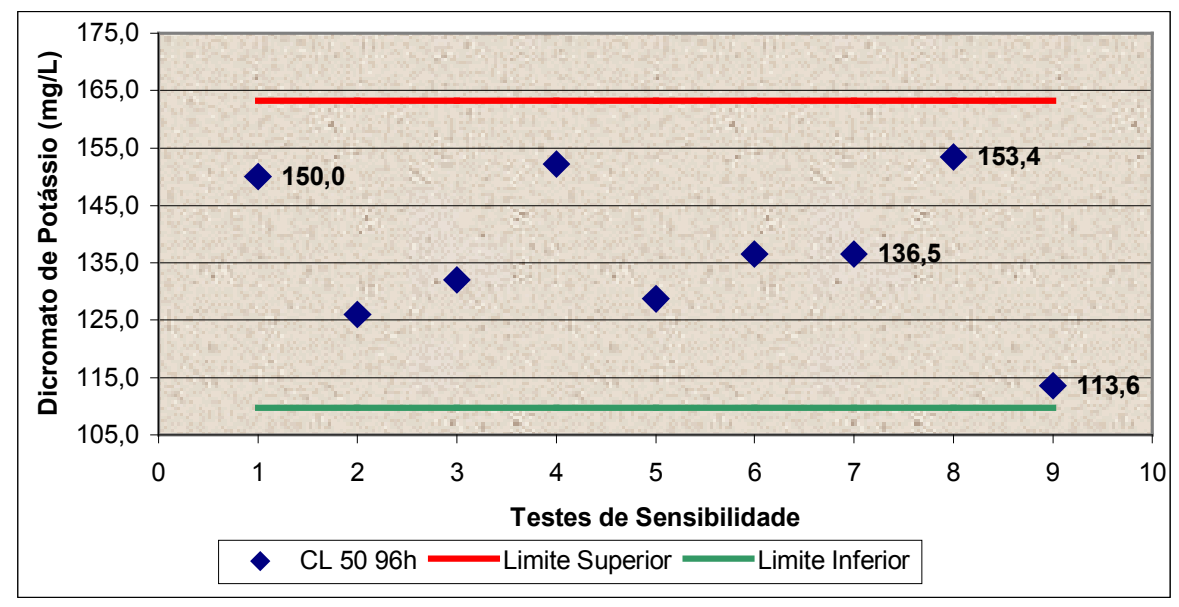

Figura 6.30. Faixa de sensibilidade de Danio rerio ao Dicromato de Potássio ao longo do desenvolvimento do estudo.

Os resultados dos testes de sensibilidade com C. silvestrii, utilizando cloreto de sódio como substância de referência, permitiram calcular uma faixa de sensibilidade que variou de 0,75 a $1,81 \mathrm{~g} / \mathrm{L}$ (figura 6.31). 




Figura 6.31. Faixa de sensibilidade de C. silvestrii ao Cloreto de Sódio ao longo do desenvolvimento do estudo.

Novamente, os valores de CE50-48h que aparecem em destaque na figura 6.31 foram obtidos em testes de sensibilidade conduzidos nos mesmos meses em que foram realizados os bioensaios com amostras de esgoto. Nota-se que, no teste 4, C. silvestrii se mostrou um pouco mais resistente ao cloreto de sódio do que nos outros testes, porém, mesmo assim, sua sensibilidade permaneceu dentro do limite aceitável.

Para C. xanthus, a faixa de sensibilidade ao cloreto de potássio obtida neste estudo foi de 2,28 a 5,52mg/L (figura 6.32).

Nota-se que os valores de CL50-96h apresentados na figura 6.32, os quais foram obtidos em testes de sensibilidade conduzidos nos mesmos meses em que foram realizados os bioensaios com amostras de esgoto, encontram-se compreendidos na faixa aceitável de sensibilidade dos organismos, indicando a qualidade do ensaio ecotoxicológico.

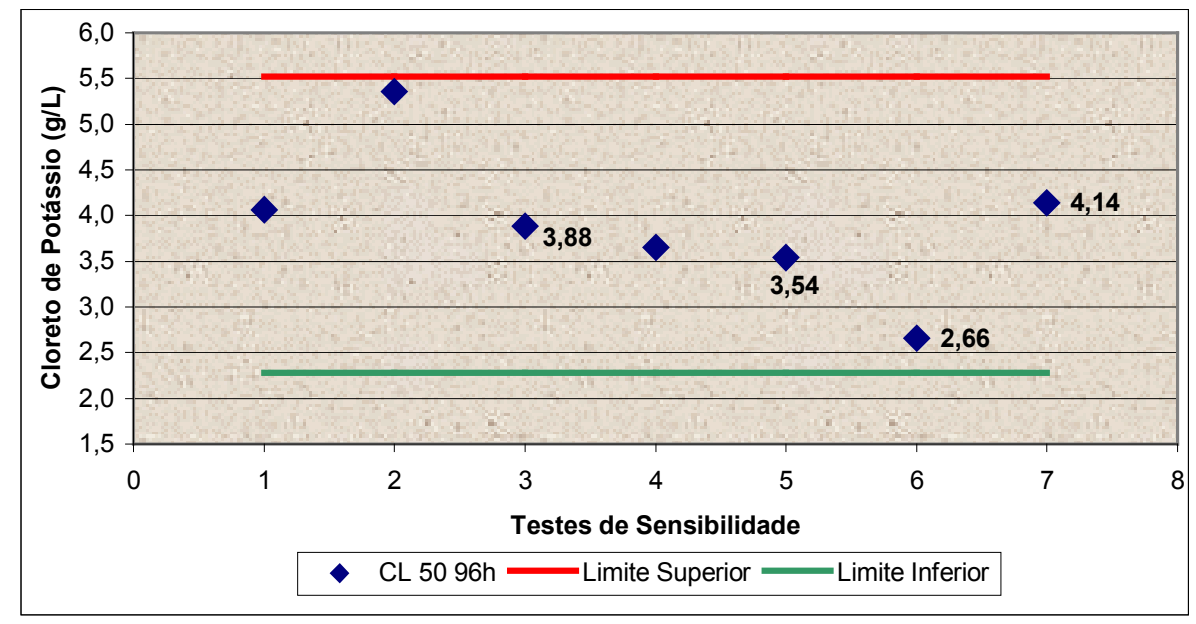

Figura 6.32. Faixa de sensibilidade de C. xanthus ao Cloreto de Potássio ao longo do desenvolvimento do estudo. 
Para $A$. сеpa, não foi possível calcular sua faixa de sensibilidade ao sulfato de cobre devido à pequena quantidade de testes de sensibilidade realizados ao longo do estudo (apenas 3), cujos resultados são apresentados nas tabelas 6.27, 6.28 e 6.29. No entanto, por meio de interpolação gráfica foi possível obter as CE50-72h para todos os testes realizados. No primeiro bioensaio, foi calculado o valor de CE50-72h de 0,48mg/L de sulfato de cobre. No segundo, o valor de CE50-72h foi de $0,37 \mathrm{mg} / \mathrm{L}$. Já no terceiro teste, o valor encontrado de CE50-72h foi de $0,57 \mathrm{mg} / \mathrm{L}$. Esses valores não foram considerados discrepantes e, portanto, mostraram-se aceitáveis.

Tabela 6.27. Comprimento das raízes $(\mathrm{cm})$, media \pm desvio padrão e porcentagem de inibição de crescimento das raízes de $A$. cepa no $1^{\circ}$ teste de sensibilidade utilizando $\mathrm{CuSO}_{4}$ como substância de referência.

\begin{tabular}{|cccccc|}
\hline Réplicas & Controle & $\mathbf{0 , 0 5} \mathbf{~ m g} / \mathbf{L}$ & $\mathbf{0 , 1 5} \mathbf{~ m g} / \mathbf{L}$ & $\mathbf{0 , 4 5} \mathbf{~ m g} / \mathbf{L}$ & $\mathbf{1 , 3 5} \mathbf{~ m g} / \mathbf{L}$ \\
\hline 1 & 3,0 & 4,7 & 1,7 & 3,2 & 1,4 \\
2 & 4,4 & 3,1 & 3,0 & 2,2 & 0,4 \\
3 & 3,9 & 3,7 & 3,4 & 2,6 & 0,5 \\
4 & 4,2 & 3,7 & 3,0 & 1,3 & 0,9 \\
5 & 3,2 & 4,1 & 2,0 & 2,1 & 1,3 \\
\hline Média & $3,74 \pm 0,61$ & $3,86 \pm 0,59$ & $2,62 \pm 0,73$ & $2,28 \pm 0,70$ & $0,9 \pm 0,45$ \\
\hline Inibição (\%) & - & $-3,2$ & 29,9 & 39,0 & 75,9 \\
\hline
\end{tabular}

Tabela 6.28. Comprimento das raízes $(\mathrm{cm})$, media \pm desvio padrão e porcentagem de inibição de crescimento das raízes de $A$. cepa no $2^{\circ}$ teste de sensibilidade utilizando $\mathrm{CuSO}_{4}$ como substância de referência.

\begin{tabular}{|cccccc|}
\hline Réplicas & Controle & $\mathbf{0 , 0 5} \mathbf{~} \mathbf{g} / \mathbf{L}$ & $\mathbf{0 , 1 5} \mathbf{~} \mathbf{g} / \mathbf{L}$ & $\mathbf{0 , 4 5} \mathbf{~} \mathbf{g} / \mathbf{L}$ & $\mathbf{1 , 3 5} \mathbf{~} \mathbf{g} / \mathbf{L}$ \\
\hline 1 & 3,5 & 3,2 & 2,0 & 2,1 & 0,4 \\
2 & 3,7 & 3,4 & 1,3 & 0,7 & 0,5 \\
3 & 2,7 & 3,1 & 1,5 & 1,5 & 0,9 \\
4 & 2,5 & 4,8 & 1,7 & 0,7 & 0,3 \\
5 & 2,5 & 4,7 & 2,7 & 1,1 & 0,4 \\
\hline Média & $2,98 \pm 0,58$ & $3,84 \pm 0,84$ & $1,84 \pm 0,55$ & $1,22 \pm 0,59$ & $0,5 \pm 0,23$ \\
\hline Inibição (\%) & - & $-28,86$ & 38,25 & 59,06 & 83,22 \\
\hline
\end{tabular}


Tabela 6.29. Comprimento das raízes $(\mathrm{cm})$, media \pm desvio padrão e porcentagem de inibição de crescimento das raízes de $A$. cepa no $2^{\circ}$ teste de sensibilidade utilizando $\mathrm{CuSO}_{4}$ como substância de referência.

\begin{tabular}{|cccccc|}
\hline Réplicas & Controle & $\mathbf{0 , 0 5} \mathbf{~} \mathbf{g} / \mathbf{L}$ & $\mathbf{0 , 1 5} \mathbf{~ m g} / \mathbf{L}$ & $\mathbf{0 , 4 5} \mathbf{~ m g} / \mathbf{L}$ & $\mathbf{1 , 3 5} \mathbf{~} \mathbf{g} / \mathbf{L}$ \\
\hline 1 & 4,5 & 6,0 & 3,5 & 3,3 & 1,2 \\
2 & 4,2 & 5,0 & 2,9 & 1,5 & 1,5 \\
3 & 5,1 & 4,7 & 3,3 & 2,7 & 2,0 \\
4 & 3,7 & 6,4 & 3,2 & 1,8 & 1,3 \\
5 & 3,5 & 6,1 & 4,7 & 1,6 & 0,5 \\
\hline Média & $4,2 \pm 0,64$ & $5,6 \pm 0,74$ & $3,5 \pm 0,69$ & $2,2 \pm 0,79$ & $1,3 \pm 0,54$ \\
\hline Inibição (\%) & 0 & $-34,28$ & 16,19 & 48,10 & 69,05 \\
\hline
\end{tabular}




\section{CONCLUSÕES E CONSIDERAÇÕES FINAIS}

Considerando os resultados obtidos neste estudo, pode-se concluir que:

1. A eficiência apresentada pela ETE-Araraquara na melhoria da qualidade do efluente tratado em relação ao afluente bruto, evidenciada por análises físicas e químicas, apesar de não satisfatória em termos de remoção de matéria orgânica, promoveu a redução de toxicidade do esgoto, o que foi verificado por meio de bioensaios.

2. Foi identificada variação temporal da grande maioria dos parâmetros físicos, químicos e bacteriológicos analisados para o esgoto tratado na ETE-Araraquara, o que também acarretou em variação de seu potencial tóxico ao longo do tempo. Essas variações, que também já foram reportadas na literatura, ocorrem em função de alterações na eficiência do sistema de tratamento de esgotos e/ou dos diferentes usos ao qual a água foi submetida.

3. De acordo com os bioensaios realizados com C. silvestrii, D. rerio e A. cepa, a amostra de esgoto mais tóxica foi coletada em 26/04/2004 ( $2^{\text {a }}$ coleta), sendo seguida pelas amostras de $5 / 7 / 2004$ ( $3^{\text {a }}$ coleta $)$ e 17/11/2004 ( $4^{\text {a }}$ coleta $)$ e, por último, pela amostra de $15 / 09 / 03\left(1^{\text {a }}\right.$ coleta).

4. A toxicidade do efluente observada nas diferentes amostragens sugere que o tratamento promovido pela ETE-Araraquara não foi suficiente para remover todos os toxicantes presentes nas águas residuárias oriundas da cidade de Araraquara, indicando que o efluente pode contribuir para a degradação do corpo hídrico receptor dependendo do fator de diluição apresentado (vazão do efluente:vazão do rio). Todavia, ressalta-se que o lançamento do esgoto in natura no Ribeirão das Cruzes provocaria um maior prejuízo para a biota local.

5. De uma maneira geral, as concentrações dos parâmetros físicos, químicos e bacteriológicos encontradas no efluente, mantiveram-se dentro dos limites estabelecidos pelas Resoluções do CONAMA ( $\mathrm{N}^{\circ}$ 20/86 e $\mathrm{N}^{\circ} 357 / 2005$ ) e pelo Decreto Estadual $\mathrm{N}^{\circ}$ 8.468/76 para corpos d'água de classe 4 . No entanto, a concentração de amônia foi superior ao padrão de lançamento determinado pelo Decreto Estadual $N^{\circ} 8.468 / 76(5 \mathrm{mg} / \mathrm{L})$ nas amostragens de $15 / 09 / 2003,26 / 04 / 2004$ e 05/07/2004. O mesmo ocorreu para os valores de $\mathrm{DBO}_{5}$ nas amostras coletadas em 15/09/2003, 05/07/2004 e 17/11/2004, já que o limite máximo de lançamento, que é de $60 \mathrm{mg} / \mathrm{L}$, foi ultrapassado.

6. Comparando todos os métodos de desinfecção estudados, pode-se considerar que, nas condições testadas, todos os desinfetantes foram bem sucedidos na inativação de E. coli. Em termos gerais, para as doses e tempos de contato testados e para a mesma amostra de efluente, verificou-se a seguinte ordem decrescente de eficiência de inativação de E. coli: cloro $>$ ácido peracético $>$ ozônio $>$ radiação UV.

7. Com relação aos bioensaios de toxicidade, observou-se que cada espécie apresenta sensibilidades e tolerâncias específicas a diferentes agentes tóxicos, o que foi evidenciado pelas respostas diferenciadas de cada organismo-teste aos diversos tratamentos.

8. Todos os desinfetantes, nas condições experimentais testadas, foram capazes de produzir efeitos deletérios aos organismos-teste utilizados nesta pesquisa. 
9. De uma maneira geral, para as condições experimentais estudadas, o cloro foi considerado o desinfetante mais tóxico aos organismos-alvo, sendo seguido pelo ozônio, ácido peracético e radiação UV.

10. O cloro, na maior concentração testada $(7 \mathrm{mg} / \mathrm{L})$, foi tóxico a todos os organismos-teste, indicando que quando essa substância é adicionada a um efluente em concentrações superiores à sua demanda, as conseqüências podem ser desastrosas à biota do corpo hídrico receptor, podendo prejudicar inclusive a comunidade bentônica. Ressalta-se que mesmo a menor concentração de cloro estudada $(2,5 \mathrm{mg} / \mathrm{L})$ proporcionou efeito tóxico a $D$. similis, $D$. rerio e $C$. silvestrii superior à provocada pelos outros agentes de desinfecção.

11. O ozônio, de uma maneira geral, foi o segundo desinfetante mais tóxico aos organismos testados. As duas doses efetivas de ozônio estudadas $\left(29,9\right.$ e $\left.45,15 \mathrm{mgO}_{3} / \mathrm{L}\right)$ provocaram toxicidade aguda em $D$. similis, $D$. rerio e $C$. silvestrii.

12. Quanto ao ácido peracético, pode-se considerar que o tratamento com a maior concentração $(10 \mathrm{mg} / \mathrm{L})$ e tempo de contato (40 min.) provocou toxicidade em $D$. similis, $C$. silvestrii, $D$. rerio e $A$. cepa. Também foi verificado que a menor concentração testada de PAA $(5 \mathrm{mg} / \mathrm{L})$ foi deletéria aos referidos organismos-alvo quando suas concentrações residuais foram maiores, isto é, quando a demanda de PAA pelo efluente foi menor, o que ocorreu nas amostras coletadas em 26/04/2004.

13. Com relação à radiação $U V$, nas condições experimentais estudadas, este agente de desinfecção causou toxicidade somente quando os organismos-teste também sofreram efeitos deletérios ao efluente não desinfetado. Nesses casos, seu efeito tóxico foi superior ao do ácido peracético (exceção seja feita ao teste com C. silvestrii).

14. Notou-se que quando o efluente não desinfetado mostrou-se, por si só, tóxico aos organismos-teste, sua toxidez foi potencializada com a adição dos diferentes agentes desinfetantes.

15. A utilização do cloro para desinfecção de efluentes de estações de tratamento de esgotos, sem prévia descloração, deve ser revista em face da eficiência satisfatória de inativação de bactérias proporcionada por outros agentes de desinfecção potencialmente menos tóxicos.

16. A hipótese do presente trabalho foi confirmada; isto é, todos os agentes desinfetantes ora estudados, apesar de promoverem redução dos microorganismos patogênicos presentes no esgoto sanitário, também podem produzir compostos tóxicos, dependendo dos precursores existentes no efluente e das doses dos desinfetantes, apresentando, portanto, potencial para causar problemas ambientais.

17. No Brasil, estudos de avaliação do potencial tóxico de agentes desinfetantes utilizados na desinfecção de esgotos sanitários devem ser estimulados, já que se trata de assunto relevante e há poucas informações disponíveis sobre o tema. 


\section{REFERÊNCIAS BIBLIOGRÁFICAS ${ }^{2}$ :}

ABNT - Associação Brasileira de Normas Técnicas. NBR 13373:2005: Ecotoxicologia aquática Toxicidade crônica - Método de ensaio com Ceriodaphnia spp (Crustacea, Cladocera). Rio de Janeiro, 2005. 15 p.

. Projeto 00:001.44-001: Ecotoxicologia aquática - Toxicidade aguda - Método de ensaio com peixes. Rio de Janeiro, 2003. 15p.

NBR 6023: Informação e documentação - Referências - Elaboração. Rio de Janeiro, 2002. 24p.

ACHER, A.; FISCHER, E.; TURNHEIM, R.; MANOR, Y. Ecologically friendly wastewater disinfection techniques. Water Research, vol. 31, nº 6, p. 1398-1404, 1997.

AISSE, M. M. et al. Cloração e Descloração. In: GONÇALVES, R. F. (Coord.). Projeto PROSAB. Desinfeç̧ão de efluentes sanitários.. Rio de Janeiro: ABES, RiMa, 2003. p. 113-168.

ALMEIDA, C. A. Estudo ecotoxicológico do sedimento do rio Tietê com o organismo-teste bentônico Chironomus xanthus Rempel (Insecta: Diptera). 2002. 119f. Dissertação (Mestrado) - EESC-USP, São Carlos, 2002.

ALMEIDA, C. A. Aspectos do ciclo de vida de espécies bentônicas nativas e sua utilização na avaliação da qualidade de sedimentos de lagos naturais e reservatórios. 2007. 166f. Tese (Doutorado) EESC-USP. São Carlos, 2007.

ALVES, C. V. P. Ampliação de escala e avaliação de um fotorreator simplificado de radiação UV na desinfecção de esgotos tratados. 2003. 124f. Dissertação (Mestrado) - Escola de Engenharia - UFMG, Belo Horizonte, 2003.

ANDRADE NETO, C. O. \& CAMPOS, J.R. (Coord.). Projeto PROSAB. Tratamento de esgotos sanitários por processo anaeróbio e disposição controlada no solo. Rio de Janeiro: ABES, RiMa, 1999. 464p.

ANDRADE NETO, C. O.; GALVÃO, M. V.; MELO, H. N.S. Desinfecção de efluente de filtros anaeróbios: avaliação de eficiência em tanque de contato piloto e em escala real. In: Simpósio Luso-Brasileiro de Engenharia Sanitária e Ambiental, 10., 2002, Braga. Anais... Braga: APESB/APRH/ABES, 2002a. 12p. CD-ROM.

ANDRADE NETO, C. O.; GALVÃO, M. V.; MELO, H. N.S.; MELO, J. L.S.; RODRIGUES, J. I. C. Desinfecção de efluente de filtros anaeróbios: pesquisa em jar-test e em tanque de contato. In:

\footnotetext{
${ }^{2}$ A norma utilizada para a elaboração das Referências Bibliográficas seguiu a ABNT - NBR 6023 (2002).
} 
Congresso Interamericano de Engenharia Sanitária e Ambiental, 28., 2002, Cancun. Anais... Cancun: FEMISCA/ABES, 2002b.

APHA/AWWA/WPCF. - American Public Health Association (APHA), American Water Works Association (AWWA), Water Pollution Control Federation (WPCF). Standard Methods for the Examination of Water and Wastewater. 20a Ed. Washington DC: Byrd Prepress Springfield, 1998. 1134p.

ARAÚJO, J. C. Estudo da eficiência do tratamento de efluentes domésticos da cidade de Araraquara SP na remoção de hormônios sexuais. 2006. 83f. Dissertação (Mestrado) - Instituto de Química de São Carlos - EESC - USP, São Carlos, 2006.

ARAÚJO, R. P. A.; SHIMIZU, G. Y.; ALMEIDA, C. A.; ROCHA, O. Testes com invertebrados para avaliar a toxicidade de contaminantes associados ao sedimento de ecossistemas de água doce. In: MOZETO, A. A; UMBUZEIRO, G. A; JARDIM, W. F. (Ed.). Projeto Qualised. Métodos de coleta, análises físico-químicas e ensaios biológicos e ecotoxicológicos de sedimentos de água doce. $1^{\text {a }}$ Edição. São Carlos: Cubo Multimidia, 2006. p. 111-133.

AZEVEDO, F. A. \& CHASIN, A. A. M. (Coord.). As bases toxicológicas da ecotoxicologia. São Carlos: RiMa, 2003. 340p.

BALDRY, M. G. C. et al. Effluent disinfection in warm climates with peracetic acid. Water Science Technology, vol. 31, nº 5, p. 161-164, 1995.

BANCO MUNDIAL. A agenda ambiental marrom - Brasil: Gestão dos problemas da poluição Relatório de Política. Brasil. 1998.

O Banco Mundial e o setor água. Brasília. /folder/ 2000. 38p.

BASTOS, R. K. X. (Coord.). Projeto PROSAB. Utilização de esgotos tratados em fertirrigação, hidroponia e piscicultura. Rio de Janeiro: ABES, RiMa, 2003. 267p.

BAUDIN, J.P. \& NUCHO, R. ${ }^{60} \mathrm{Co}$ accumulation from sediment and planktonic algae by midge larvae Chironomus luridus. Environment Pollution, vol. 76, p. 133-140. 1992.

BILOTTA, P. Estudo comparativo da ação do ozônio e radiação UV na desinfecção de esgoto sanitário. 2000. 96f. Dissertação (Mestrado) - EESC - USP, São Carlos, 2000.

BITTON, G. Wastewater microbiology. New York: John Wiley \& Sons, 1994.

BLATCHLEY III, E.R. et. al. Effects of disinfectants on wastewater effluent toxicity. Water Research, vol. 31, no 7, p. 1581-1588, 1997. 
BRASIL. Ministério da Saúde. Secretaria de Vigilânica em Saúde. Coordenação-Geral de Vigilância em Saúde Ambiental. Portaria MS n. ${ }^{\circ}$ 518/2004/ Ministério da Saúde, Secretaria de Vigilância em Saúde, Coordenação-Geral de Vigilância em Saúde Ambiental. Brasília: Editora do Ministério da Saúde, 2005. 28p. (Série E. Legislação em Saúde).

BUSCHINI, A. et al. Sodium hipochlorite, chlorine dioxide and peracetic acid induced genotoxicity detected by the Comet assay and Saccharomyces cerevisiae D7 tests. Mutagenesis, vol. 19, $\mathrm{n}^{\mathrm{o}}$ 2, p.157-162, 2004.

CAMACHO, P. R. R. Desinfecção de efluentes de sistemas de tratamento de esgotos sanitários por meio da radiação ultravioleta. 1995. 94f. Dissertação (Mestrado) - EESC - USP, São Carlos, 1995.

CAMPOS, J. R. Uma abordagem sobre a desinfecção de esgotos no Brasil. In: Seminário Internacional sobre desinfecção de águas de abastecimento e residuárias em países em desenvolvimento, 1993, Belo Horizonte. Anais... Belo Horizonte: ABES, 1993, p. 137-167.

CASTRO SILVA, J. C. Avaliação de um fotorreator simplificado de radiação UV utilizado na inativação de coliformes e ovos de helmintos em esgotos tratados. 2001. 97f. Dissertação (Mestrado) - Escola de Engenharia - UFMG, Belo Horizonte, 2001.

CETESB - COMPANHIA DE TECNOLOGIA DE SANEAMENTO AMBIENTAL. Relatório de qualidade de águas interiores do estado de São Paulo, 2000. São Paulo, 2001. 371p.

Métodos de avaliação da toxicidade de poluentes a organismos aquáticos. Normas Técnicas L5.018, L5.019 e L5.022. São Paulo, 1992. (Série Didática - Água).

CHASIN, A. A. M \& PEDROZO, M. F. M. O estudo da toxicologia. In: Azevedo, F. A. \& Chasin, A. A. M. (Coord.). As bases toxicológicas da ecotoxicologia.. São Carlos: RiMa, 2003. p. 1-25.

COLETTI, F. J. Inativação de microorganismos indicadores presentes em efluentes secundários de esgoto sanitário com radiação ultravioleta. 2003. 239f. Tese (Doutorado) - EESC - USP, São Carlos, 2003.

COGNET, L.; COURTOIS, Y.; MALLEVIALLE, J. Mutagenic activity of disinfection by-products. Environ Health Perspect, vol. 69, p.165-75, 1986.

CONAMA - CONSELHO NACIONAL DO MEIO AMBIENTE. Resolução no 357, de 17 de março de 2005. 2005. 23p.

. Resolução nº 20, de 18 de junho de 1986. 1986. 13p. 
COWMAN, G. A. \& SINGER, P. C. Effect of bromide ion on haloacetic acid speciation resulting from chlorination and chloroamination of aquatic humic substances. Environmental Science Technology, vol. $30, n^{\circ} 1$, p. 16-24, 1996.

CRANSTON, P. S. Introduction. In: ARMITAGE, P.; CRANSTON, P.S; PINDER, L.C.V. (Ed.). The Chironomidae - the biology and ecology of nonbitng midges. London: Chapman \& Hall, 1995. p.15.

DANIEL, L. A. (Coord.). Projeto PROSAB. Processos de desinfecção e desinfetantes alternativos na produção de água potável. Rio de Janeiro: ABES, RiMa, 2001. 155p.

De LUCA, S. J. ; CARDOSO, L. S. Toxidez de Efluentes biologicamente tratados e desinfetados com hipoclorito e ferrato de sódio. Revista Brasileira de Engenharia Sanitária e Ambitental, v. 9, n. 1, p. 35-47, 2004

DIAS, V. D. Radiação ultravioleta e ozônio aplicados como métodos alternativos de desinfecção de efluentes secundários de esgotos. 2001. 150f. Dissertação (Mestrado) - EESC - USP, São Carlos, 2001.

DORNFELD, C. B. Utilização de análises limnológicas, bioensaios de toxicidade e macroinvertebrados bentônicos para o diagnóstico ambiental do reservatório de Salto Grande (Americana, SP). 2002. 211f. Dissertação (Mestrado) - EESC - USP, São Carlos, 2002.

ENVIRONMENT CANADA. Guidance document on control of toxicity test precision using reference toxicants. 1990. 85p. Report EPS 1/RM/12.

FERREIRA, M.D. Cultura da cebola: recomendações técnicas. Campinas: ASGROW, 2000. 36p.

FISCHER, D. J.; BURTON, D. T.; YONKOS, L. T. The relative acute toxicity of continuous and intermitent exposures of chlorine and bromine to aquatic organisms in the presence and absence of ammonia. Water Research, vol. 33, nº 3, p. 760-768, 1999.

FISKESJÖ, G. Allium test I: a 2-3 day plant test for toxicity assessment by measuring the mean root growth of onions (Allium cepa L.). Environ. Toxicol. and Water Quality, vol. 8, p. 461-470, 1993.

FISKESJÖ, G. The Allium test as a standard in environmental monitoring. Hereditas, $\mathrm{n}^{\circ} 102$, p. 99-112, 1985.

FONSECA, A L. Avaliação da qualidade da água na bacia do rio Piracicaba através de testes de toxicidade com invertebrados. 1997. 184f. Tese (Doutorado) - EESC - USP, São Carlos, 1997. 
GASI, T. M. T. et al. Aplicação de ácido peracético para desinfecção de efluentes de lodos ativados. In: Congresso Brasileiro de Engenharia Sanitária e Ambiental, 19., 1995, Salvador. Anais... Salvador, 1995.

GHERARDI-GOLDSTEIN, E. et al. (Coord.). Procedimentos para utilização de testes de toxicidade no controle de efluentes líquidos. São Paulo: CETESB, 1990. 17p.

GIESY, J. P. et al. Comparison of three sediment bioassay methods using Detroit river sediments. Environ. Toxicol. Chem, vol. 7, p.483-498, 1988.

GJESSING, E. T. \& KÄLLQVIST, T. Algicidal and chemical effect of UV-radiation of water containing humic substances. Water Research, vol. 25, p. 491-494, 1991.

GOlterman, H. L. \& CLYMO, R. S.; OHNSTAD, M.A M. Methods Chemical and Phisical Analysis of Freshwater. IBP Handbook n ${ }^{\circ}$.8. Oxford: Blackwell Scientific Publications, 1978. 213 p.

GONÇALVES, R. F. (Coord.). Projeto PROSAB. Desinfecção de efluentes sanitários. Rio de Janeiro: ABES, RiMa, 2003. 422p.

GONÇALVES, R. F.; JORDÃO, E. P.; SOBRINHO, P. A. Introdução. In: GONÇALVES, R. F. (Coord.). Projeto PROSAB. Desinfecção de efluentes sanitários. Rio de Janeiro: ABES, RiMa, 2003. p. 1-26.

GUSMÃO, L. F. M. Efeitos do cobre e cromo na comunidade zooplanctônica: um estudo experimental em mesocosmos. 2004. 268f. Dissertação (Mestrado) - EESC - USP, São Carlos, 2004.

HAMILTON, M. A.; RUSSO, R. C. \& THURSTON, R. V. Trimmed Spearman-Karber method for estimating median lethal concentrations in toxicity bioassays. Environmental Science Technology, vol.11, nº 7, p. 714-719, 1977.

HASHIMOTO, S.; AZUMA, T.; OTSUKI, A. Distribution, sources and stability of haloacetic acids in Tokio Bay, Japan. Environ. Toxicol. Chem., vol. 17, nº 5, p. 798-805, 1998.

HATCHARD, C. G.; PARKER, C. A. A new sensitive chemical actinometer: II. Potassium ferrioxalate as a standard chemical actinometer. Proceedings of the Royal Society of London, Series A, vol. 235, p. 518-536, 1956.

HEBERT, P. D. N. The population Biology of Daphnia (Crustácea, Daphnidae). Biol. Ver., vol. 53, p. 387426, 1978.

HOFFMAN, D. J. et al. (Ed.). Handbook of Ecotoxicology. Lewis Publishers CRC, 1995. 755p. 
IBAMA - INSTITUTO BRASILEIRO DO MEIO AMBIENTE E DOS RECURSOS NATURAIS RENOVÁVEIS. Manual de testes para avaliação da ecotoxicidade de agentes químicos. $2^{\mathrm{a}}$ Edição. Brasília, 1990. 15p.

IBGE - INSTITUTO BRASILEIRO DE GEOGRAFIA E ESTATÍSTICA (2000). Pesquisa nacional de saneamento básico. 2000. Disponível em: <http:/www.ibge.gov.br>. Acesso em fevereiro de 2004.

IBGE - INSTITUTO BRASILEIRO DE GEOGRAFIA E ESTATÍSTICA. Anuário estatístico de 1996. Rio de Janeiro, 1998.

JARDIM, G. M. Estudos ecotoxicológicos da água e do sedimento do rio Corumbataí, SP. Dissertação de Mestrado. 2004. 127f. Dissertação (Mestrado) - ESALQ - USP, Piracicaba, 2004.

JOVILET-GOUGEON et al. Influence of peracetic acid on Escherichia coli H 10407 strain in laboratory microcosms. Can. J. Microbiol., vol. 42, p. 60-65, 1996.

KOPECKY, J. Organic Photochemistry: A Visual Approach. New York: VCH, 1992.

KOROLEFF, F. Determinations of ammonia. In: GRASHOFF. K. (Ed.). Methods of seawater analysis. Verlag Chenie Weinheim, 1976. p. 126-133.

LANGLAIS, B; RECKHOW, D. A.; BRINK, D. R. Ozone in water treatment. Application and engineering. Lewis Publishers, Inc. Chelsea, 1991.

LAPOLLI, F. R. et al. Desinfecção de efluentes sanitários por meio da ozonização. In: GONÇALVES, R. F. (Coord.). Projeto PROSAB. Desinfecção de efluentes sanitários. Rio de Janeiro: ABES, RiMa, 2003. p. 169-208.

LARA, A. I.; ANDREOLI, C. V. \& ANDREOLI, F. N. Conservação de mananciais: a visão das companhias de saneamento. In: Congresso Brasileiro de Engenharia Sanitária e Ambiental, 20., 1999, Rio de Janeiro. Anais... Rio de Janeiro, 1999. p. 3760-3764.

LIMA, J. E. F. W. Determinação e simulação da evapotranspiração de uma bacia hidrográfica do Cerrado. 2000. 75f. Dissertação (Mestrado) - FAV-UnB, Brasília, 2000.

LINDEGAARD, C. Classification of water-bodies and pollution. In: ARMITAGE, P.; CRANSTON, P. S.; PINDER, L. C. V. (Ed.). The Chironomidae - The biology and ecology of nonbiting midges. London: Chapman \& Hall, 1995. p. 385-404.

LUCCA, J. V. Caracterização limnológica e análise de comunidades bentônicas sujeitas à invasão por espécies exóticas em lagos do Vale do Rio Doce, MG, Brasil. 2006. 215f. Tese (Doutorado) - EESC - USP, São Carlos, 2006. 
LUND, V. \& HONGVE, D. Ultraviolet irradiated water containing humic substances inhibits bacterial metabolism. Water Research, vol. 28, p. 1111-1116, 1994.

MACÊDO, J. A. B. Determinação de Trihalometanos em Águas de Abastecimento Público e Indústria de Alimentos. 1997. 90f. Tese (Doutorado) - UFV, Viçosa, 1997.

MACKERETH, F. J. H.; HERON, J.; TALLING, J. E. Water analysis revised methods for limnologists. Freshwaters Biological Association. Sci. Publ. No36. Titus: Wilson and Sons LTDA, Kendall, 1978. $117 \mathrm{p}$.

MATTHEWS, R.W. Environment: photochemical and photocatalytic processes. Degradation of organic compounds. In: PELIZZEtTi, E. \& SCHIAVEllo, M. (Ed.). Photochemical Conversion and Storage of Solar Energy. The Netherlands: Kluwer Academic, 1991.

MONACO, P. B. Inativação de indicadores patogênicos em sistemas combinados de tratamento e prédesinfecção de esgoto sanitário. 2006. 136f. Tese (Doutorado) - EESC - USP, São Carlos, 2006.

MONARCA, S. et. al. Genotoxicity of surface water treated with different disinfectants using in situ plant tests. Environ. Mol. Mutagen, vol. 41, p. 353-359, 2003.

MONARCA, S. et. al. Mutagenicity and disinfection by-products in surface drinking water disinfected with peracetic acid. Environ. Toxicol. Chem., vol. 21, nº 2, p. 309-318, 2002 a.

MONARCA, S. et. al. Studies on mutagenicity and disinfection by-products in river drinking water disinfected with peracetic acid or sodium hypochlorite. Water Supply, vol. 2, no . 3, p. 199-204, 2002b.

MONARCA, S. et. al. The influence of different disinfectants on mutagenicity and toxicity of urban wastewater. Water Research, vol. 34, nº 17, p.4261-4269, 2000.

NIPPER, M. Testes estatísticos para a análise de resultados de testes de toxicidade com amostras líquidas e sedimentos. In: NASCIMENTO, I.A.; SOUSA, E.C.P.M. \& NIPPER, M. (Ed.). Métodos em ecotoxicologia marinha: Aplicações no Brasil. São Paulo: Editora Artes Gráficas e Indústria Ltda., 2002. p. 245-253.

NIPPER, M \& CARR, R. S. Bio e foto-degradação de contaminantes em ambientes marinhos: implicações para a biota. In: Congresso Brasileiro de Ecotoxicologia, 7. e Reunião da SETAC Latino-Americana, 5., 2002, Espírito Santo. Resumos... Espírito Santo: UFES, 2002. p.43.

NURIZZO, C.; ANTONELLI, M; PROFAIZER, M; ROMELE, L. By-products in surface and reclaimed water disinfected with various agents. Desalination, vol. 176, p. 241-253, 2005. 
OGERA, R. C. Análise de gestão local e estadual dos serviços de água e esgoto no Estado de São Paulo, 1996 - 2000. 2002. 200f. Tese (Doutorado) - Faculdade de Saúde Pública - USP, São Paulo. 2002.

ORANGE COAST WATCH. Issue paper. Issues regarding disinfection of wastewater using sodium hypochlorite. Califórnia, 2002. 47p.

OTAKI, M.; OHGAKI, S. Photochemical decomposition of organo-clorine compounds by a medium pressure UV lamp. Proc. Water Quality International '94, IAWQ Biennial Conf., Budapest. 1994.

PAMPLIN, P. A. Z. Avaliação da qualidade amibental da represa de Americana (SP-Brasil) com ênfase no estudo da comunidade de macroinvertebrados bentônicos e parâmetros ecotoxicológicos. 1999. 88f. Dissertação (Mestrado) - EESC - USP, São Carlos, 1999.

PARASKEVA, P.; GRAHAM, N.J.D. Treatment of a secondary municipal effluent by ozone, UV and microfiltration: microbial reduction and effect on effluent quality. Desalination, vol. 186, p. 47-56, 2005 .

PERON, K. A. Validação da metodologia analítica para a determinação do diclofenaco sódico em amostras de esgoto da estação de tratamento da cidade de Araraquara-SP. 2007. 65f. Dissertação (Mestrado) - Instituto de Química de São Carlos - EESC - USP, São Carlos, 2007.

PLEWA, M. J. et. al. Mammalian cell citotoxicity and genotoxicity analysis of drinking water disinfection by-products. Environmental and Molecular Mutagenesis, vol. 40, nº 2, p. 134-142, 2002.

PRÜSS, A. et al. Estimating the Burden of Disease from Water, Sanitation, and Hygiene at a Global Level. Environmental Health Perspectives, vol. 110, nº 5, p. 537-542, 2002.

RAND, G. M. \& PETROCELLI, S. R. (Ed.). Fundamentals of aquatic toxicology: methods and applications. Washington: Hemishphere Publishing, 1985. 666p.

RAND, G. M; WELLS, P. G.; McCARTY, L. S. Introduction to aquatic toxicology. In: RAND, G. M. (Ed.). Fundamentals of aquatic toxicology - effects, environmental fate and risk assessment. $2^{\mathrm{a}}$ Edição. Taylor \& Francis Publ, 1995. p. 3-67.

RAZZOLINI, M. T. P. Avaliação sanitária de águas residuárias provenientes de lagoas de estabilizaçäo para irrigaçäo de culturas agrícolas no estado de Säo Paulo. 2003. $203 f$. Tese (Doutorado) - Faculdade de Saúde Pública - USP, São Paulo, 2003.

REBHUN, M. et al. Formation of disinfection byproducts during chlorination of secondary effluent and renovated water. Water Environment Research, vol. 69, nº 6, p. 1154-1162, 1997. 
RIBEIRO, I. A. Teste de raízes de cebola para avaliação de toxicidade de efluentes industriais. Engenharia Sanitária e Ambiental, vol. 4, nº 3, p. 108 - 112, 1999.

RIBEIRO, L. R. (2003). Teste do micronúcleo em medula óssea de roedores in vivo. In: RIBEIRO, L. R.; SALVADORI, D. M. F. \& MARQUES, E. K. (Org.). Mutagênese Ambiental. Canoas: Ed. ULBRA, 2003. p. 173-200.

SAMPAIO, A. O. Desinfecção de esgotos sanitários com utilização de radiação ultravioleta. 1985. 96p. Dissertação (Mestrado) - EESC - USP, São Carlos, 1985.

SANCHES, S. M.; SILVA, C. H. T. P. \& VIERIA, E. M. Agentes desinfetantes alternativos para o tratamento de água. Química Nova na Escola, nº 17, p.8-12, 2003.

SANCHES, S. M. Determinação de subprodutos clorados formados durante a etapa de oxidação da água contendo substâncias húmicas. 2005. 134f. Tese (Doutorado) - EESC - USP, São Carlos, 2005.

SANTOS, C. L. O controle de trihalometanos (THM) nas águas de abastecimento público. 1988. $217 \mathrm{f}$. Dissertação (Mestrado) - USP, São Paulo, 1988.

SARTORI, L. Adequação da qualidade microbiológica de efluentes de tratamento secundário de esgoto sanitário pela aplicação dos desinfetantes ozônio, permanganato de potássio e ácido peracético. 2004. 200f. Tese (Doutorado) - EESC - USP, São Carlos, 2004.

SCALIZE, P. S. et al. Aspectos construtivos e operacionais da Estação de Tratamento de Esgotos da cidade de Araraquara - SP. In: EXPOSIÇÃO DE EXPERIÊNCIAS MUNICIPAIS EM SANEAMENTO, 7., 2003, Santo André. Anais... Santo André, 2003. 11p.

SETTI, A. A.; ANEEL (BRASIL); ANA (BRASIL). Introdução ao gerenciamento de recursos hídricos.

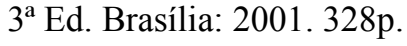

SILVA, H.K.S. \& ALVES, R.F.F. O saneamento das águas no Brasil. In: SIH/ANEEL/MME; SRH/MMA. Estado das águas no Brasil - 1999: perspectivas de gestão e informação de recursos hídricos. 1999. p. 83-101.

SILVA, A. Z., RÖRIG, L. R. \& RESGALLA JR. C. Determinação do efeito do esgoto bruto e efluente da Estação de Tratamento de Esgotos do Balneário de Camboriú (SC) sobre o crescimento de Skeletonema costatum (Baccilariophyceae). In: ESPÍNDOLA, E. L. G. et al. (Ed.). Ecotoxicologia: Perspectivas para o século XXI. São Carlos: RiMa, 2000. p. 427-439.

SOBSEY, M. D. Inactivation of health related microorganism in water disinfection processes. Water Science Technology, vol. 21, p. 179-195, 1989. 
SOUZA, J. B. Avaliação de métodos para desinfecção de água, empregando cloro, ácido peracético, ozônio e o processo de desinfecção combinado ozônio/cloro. 2006. 176f. Tese (Doutorado) - EESC USP, São Carlos, 2006.

Desinfecção de águas com cor e turbidez elevadas: comparação técnica de processos alternativos ao cloro empregando radiação ultravioleta e ácido peracético. 2000. 148f. Dissertação (Mestrado) - EESC - USP, São Carlos, 2000.

SPELLMAN, F. R. Choosing disinfection alternatives for water/wastewater treatment. Pennsylvania: Technomic Publication, 1999. 127p.

SRH/MMA - Secretaria de Recursos Hídricos do Ministério do Meio Ambiente e da Amazônia Legal. Water Resources in Brazil. 1998.

STRICKLAND, J. D. \& PARSONS, T. R. A manual of sea water analysis. Bull. Fish. Res. Can., vol.. 125, p. $1-185,1960$.

STRIXINO, S. T. \& STRIXINO, G. Ciclo de vida de Chironomus sancticaroli Strixino \& Strixino (Diptera: Chironomidae). Rev. Bras. Ent., v. 26, n² 2, p. 183-189, 1982.

TASK FORCE ON WASTEWATER DISINFECTION. Wastewater disinfection. Manual of practice. Water Environment Federation. Municipal Subcommitee. 1996. 278p. (Series Manual of Practice. FD, $\left.\mathrm{N}^{\mathrm{o}} 10\right)$.

THOMPSON, J. E. \& BLATCHLEY III, E. R. Toxicity effects of $\Upsilon$-irradiated wastewater effluents. Water Research, vol. 33, nº 9, p. 2053-2058, 1999.

TYRREL, S. A.; RIPPEY, S. R.; WATKINS, W.D. Inactivation of bacterial and viral indicators in secondary sewage effluents using chlorine and ozone. Water Reseacrh, vol. 29, nº 11, p. 2483-2499, 1995.

USEPA - United States Environmental Protection Agency. Methods for Measuring the Acute Toxicity of Effluents to Freshwater and Marine Organisms. Washington: EPA, 2002. (EPA/600/490/027F).

Controlling disinfection by-products and microbial contaminants in drinking water. Washington: EPA, 2001. (EPA 600-R-01-110).

. Alternative disinfectants and oxidants. Guidance Manual. Washington: EPA, 1999a. (EPA 815R-99-014).

. Wastewater technology fact sheet. Ultraviolet disinfection. Washington: EPA, 1999b (EPA 832-F99-064). 
. Wastewater technology fact sheet. Ozone disinfection. Washington: EPA, 1999c. (EPA 832-F-99063).

. Toxicology Handbook. Government Institutes, Inc. Washington: EPA, 1989.

VIEIRA, S. Estatística experimental. 2a Edição. São Paulo: Atlas, 1999. 185p.

VON SPERLING, M. Introdução à qualidade das águas e ao tratamento de esgotos. Vol. 1. $3^{\mathrm{a}}$ Ed. Belo Horizonte: Dep ${ }^{\text {to }}$. de Engenharia Sanitária e Ambiental, UFMG, 2005. 452p.

VON SPERLING, M. Introdução à qualidade das águas e ao tratamento de esgotos. Vol. 1. $2^{\mathrm{a}}$ Ed. Belo Horizonte: Dep ${ }^{\text {to }}$. de Engenharia Sanitária e Ambiental, UFMG, 1996.

WEINBERG, H. S. \& BLAZE, W. H. An overview of ozonation disinfection by-products. In: MINEAR, R. A. \& AMY, G. L. (Ed.). Disinfection by-products in water treatment. The chemical of their formation and control. Lewis Publishers, 1996. 502p.

WEF - Water Environmental Federation. Wastewater disinfection: manual of practice FD-10. Alexandria: WEF, 1996.

WHO - World Health Organization. Burden of disease and cost-effectiveness estimates. 2002. Disponível em: <http://www.who.ch>. Acesso em dezembro de 2003.

WHO - World Health Organization. Water and sanitation. 1998. Disponível em: <http:// www.who.ch>. Acesso em dezembro de 2003.

XU, P. et al. Wastewater disinfection by ozone: main parameters for process design. Water Research, vol. 36, p. 1043-1055, 2002. 
ANEXO I - TABELAS 
Tabela A-I.1. Resultado do teste de toxicidade aguda com amostras diluídas e integrais de esgoto bruto (afluente) e tratado (efluente) da ETEAraraquara, coletadas em 15/9/2003, utilizando D. similis como organismo-teste (48h de exposição).

\begin{tabular}{|c|c|c|c|c|c|c|c|c|c|}
\hline \multirow{2}{*}{ Amostras } & \multicolumn{2}{|c|}{ Imobilidade } & \multirow{2}{*}{$\begin{array}{l}\text { Efeito } \\
\text { Tóxico }\end{array}$} & \multicolumn{2}{|c|}{$\mathrm{pH}$} & \multicolumn{2}{|c|}{ Cond. $(\mu \mathrm{S} / \mathrm{cm})$} & \multicolumn{2}{|c|}{ Dureza (mg/L) } \\
\hline & Total & $\%$ & & Inicial & Final & Inicial & Final & Inicial & Final \\
\hline Controle & 0 & 0 & & 7,5 & 7,9 & 158,9 & 179,0 & 44,0 & 40,0 \\
\hline Efluente $100 \%$ & 0 & 0 & NT & 7,5 & 7,5 & 436,0 & 508,0 & 52,0 & 56,0 \\
\hline Efluente 75\% & 0 & 0 & NT & 7,3 & 7,6 & 422,0 & 430,0 & 52,0 & 52,0 \\
\hline Efluente $50 \%$ & 1 & 5 & NT & 7,4 & 7,7 & 412,0 & 344,0 & 50,0 & 52,0 \\
\hline Efluente $25 \%$ & 0 & 0 & NT & 7,4 & 7,6 & 375,0 & 257,0 & 48,0 & 48,0 \\
\hline Afluente $100 \%$ & 4 & 20 & IT & 7,7 & 8,0 & 607,8 & 642,0 & 320,0 & 60,0 \\
\hline Afluente $75 \%$ & 0 & 0 & NT & 7,6 & 7,9 & 584,0 & 557,0 & 305,0 & 58,0 \\
\hline Afluente $50 \%$ & 0 & 0 & NT & 7,6 & 7,9 & 522,0 & 433,0 & 280,0 & 52,0 \\
\hline Afluente $25 \%$ & 0 & 0 & NT & 7,5 & 7,8 & 430,0 & 315,0 & 220,0 & 52,0 \\
\hline
\end{tabular}

Tabela A-I. 2. Resultado do teste de toxicidade aguda com amostras diluídas e integrais de esgoto bruto (afluente) e tratado (efluente) da ETEAraraquara, coletadas em 15/9/2003, utilizando D. rerio como organismo-teste (96h de exposição).

\begin{tabular}{|c|c|c|c|c|c|c|c|c|c|}
\hline \multirow{2}{*}{ Amostras } & \multicolumn{2}{|c|}{ Mortalidade } & \multirow{2}{*}{$\begin{array}{l}\text { Efeito } \\
\text { Tóxico }\end{array}$} & \multicolumn{2}{|c|}{$\mathrm{pH}$} & \multicolumn{2}{|c|}{ Cond. $(\mu \mathrm{S} / \mathrm{cm})$} & \multicolumn{2}{|c|}{ Dureza (mg/L) } \\
\hline & Total & $\%$ & & Inicial & Final & Inicial & Final & Inicial & Final \\
\hline Controle & 0 & 0 & & 7,5 & 7,9 & 164,0 & 180,0 & 44,0 & 40,0 \\
\hline Efluente $100 \%$ & 0 & 0 & NT & 7,5 & 7,3 & 436,0 & 528,0 & 52,0 & 56,0 \\
\hline Efluente $75 \%$ & 0 & 0 & NT & 7,3 & 7,3 & 422,0 & 439,0 & 52,0 & 52,0 \\
\hline Efluente $50 \%$ & 0 & 0 & NT & 7,4 & 7,6 & 412,0 & 354,0 & 50,0 & 52,0 \\
\hline Efluente $25 \%$ & 0 & 0 & NT & 7,4 & 7,7 & 375,0 & 272,0 & 48,0 & 48,0 \\
\hline Afluente $100 \%$ & 10 & 100 & $\mathbf{T}$ & 7,7 & 7,9 & 607,8 & 768,0 & 320,0 & 70,0 \\
\hline Afluente $75 \%$ & 10 & 100 & $\mathbf{T}$ & 7,6 & 8,0 & 584,0 & 611,0 & 305,0 & 62,0 \\
\hline Afluente $50 \%$ & 0 & 0 & NT & 7,6 & 8,0 & 522,0 & 461,0 & 280,0 & 60,0 \\
\hline Afluente $25 \%$ & 0 & 0 & NT & 7,5 & 7,8 & 430,0 & 340,0 & 220,0 & 56,0 \\
\hline
\end{tabular}

NT = Não Tóxico $\quad$ IT $=$ Indícios de Toxicidade $\mathrm{T}=$ Tóxico 
Tabela A-I.3. Resultado do teste de toxicidade crônica com amostras diluídas e integrais de esgoto bruto (afluente) e tratado (efluente) da ETEAraraquara, coletadas em 15/9/2003, utilizando C. xanthus como organismo-teste (168h de exposição).

\begin{tabular}{|c|c|c|c|c|c|c|c|c|c|c|c|}
\hline \multirow{2}{*}{ Amostras } & \multicolumn{2}{|c|}{ Mortalidade } & \multirow{2}{*}{$\begin{array}{l}\text { Efeito } \\
\text { Tóxico }\end{array}$} & \multicolumn{2}{|c|}{$\mathrm{pH}$} & \multicolumn{2}{|c|}{ Cond. $(\mu \mathrm{S} / \mathrm{cm})$} & \multicolumn{2}{|c|}{ Dureza (mg/L) } & \multicolumn{2}{|c|}{ OD (mg/L) } \\
\hline & Total & $\%$ & & Inicial & Final & Inicial & Final & Inicial & Final & Inicial & Final \\
\hline Controle & 0 & 0 & & 7,80 & 7,47 & 71,2 & 152,3 & 30 & 32 & 6,6 & 5,9 \\
\hline Efluente $100 \%$ & 1 & 10 & NT & 7,50 & 7,43 & 436,0 & 579,0 & 58 & 58 & 8,5 & 3,0 \\
\hline Efluente $75 \%$ & 0 & 0 & NT & 7,26 & 7,35 & 422,0 & 454,0 & 58 & 58 & 6,7 & 3,1 \\
\hline Efluente $50 \%$ & 0 & 0 & NT & 7,35 & 7,35 & 412,0 & 325,0 & 56 & 56 & 6,7 & 3,4 \\
\hline Efluente $25 \%$ & 1 & 10 & NT & 7,38 & 7,35 & 375,0 & 218,0 & 50 & 38 & 6,9 & 4,0 \\
\hline Afluente $100 \%$ & 10 & 100 & $\mathbf{T}$ & 7,67 & 7,78 & 607,8 & 846,0 & 320 & 70 & 2,5 & 0,0 \\
\hline Afluente $75 \%$ & 7 & 70 & $\mathbf{T}$ & 7,60 & 7,66 & 584,0 & 683,0 & 305 & 68 & 2,8 & 0,6 \\
\hline Afluente $50 \%$ & 5 & 50 & $\mathbf{T}$ & 7,60 & 7,56 & 522,0 & 494,0 & 280 & 62 & 3,2 & 2,1 \\
\hline Afluente $25 \%$ & 0 & 0 & NT & 7,50 & 7,43 & 430,0 & 340,0 & 220 & 60 & 4,2 & 2,9 \\
\hline
\end{tabular}

Tabela A-I.4. Resultado do teste de toxicidade crônica com amostras diluídas e integrais de esgoto bruto (afluente) e tratado (efluente) da ETEAraraquara, coletadas em 15/9/2003, utilizando C. silvestrii como organismo-teste (168h de exposição).

\begin{tabular}{|c|c|c|c|c|c|c|c|c|c|c|c|}
\hline \multirow{2}{*}{ Amostras } & \multirow{2}{*}{$\begin{array}{c}\text { Imobilidade } \\
\%\end{array}$} & \multirow{2}{*}{$\begin{array}{c}\text { Reprodução } \\
\text { Média }\end{array}$} & \multirow{2}{*}{$\begin{array}{l}\text { Efeito } \\
\text { Tóxico * }\end{array}$} & \multicolumn{2}{|c|}{$\mathrm{pH}$} & \multicolumn{2}{|c|}{ Cond. $(\mu \mathrm{S} / \mathrm{cm})$} & \multicolumn{2}{|c|}{ Dureza (mg/L) } & \multicolumn{2}{|c|}{ OD (mg/L) } \\
\hline & & & & Inicial & Final & Inicial & Final & Inicial & Final & Inicial & Final \\
\hline Controle & 0 & 17,6 & & 7,80 & 7,50 & 161,3 & 183,2 & 46 & 42 & 6,8 & 5,6 \\
\hline Efluente $100 \%$ & 100 & 0 & $\mathbf{T}$ & 7,50 & 7,46 & 436,0 & 606,0 & 58 & 52 & 8,5 & 5,0 \\
\hline Efluente $75 \%$ & 90 & 0 & $\mathbf{T}$ & 7,26 & 7,55 & 422,0 & 437,0 & 58 & 54 & 6,3 & 5,0 \\
\hline Efluente $50 \%$ & 80 & 0,5 & $\mathbf{T}$ & 7,35 & 7,67 & 412,0 & 350,0 & 56 & 52 & 6,4 & 5,2 \\
\hline Efluente 25\% & 0 & 6,9 & $\mathbf{T}$ & 7,38 & 7,68 & 375,0 & 259,0 & 54 & 48 & 6,6 & 5,5 \\
\hline Afluente $100 \%$ & 100 & 0 & $\mathbf{T}$ & 7,67 & 8,01 & 607,8 & 780,0 & 320 & 58 & 2,5 & 0,0 \\
\hline Afluente $75 \%$ & 80 & 0 & $\mathbf{T}$ & 7,60 & 8,06 & 584,0 & 608,0 & 305 & 50 & 2,8 & 1,2 \\
\hline Afluente $50 \%$ & 0 & 3,2 & $\mathbf{T}$ & 7,60 & 8,02 & 522,0 & 461,0 & 280 & 48 & 3,2 & 2,1 \\
\hline Afluente $25 \%$ & 30 & 11,5 & NT & 7,50 & 7,92 & 430,0 & 324,0 & 220 & 46 & 4,2 & 2,9 \\
\hline
\end{tabular}


Tabela A-I.5. Resultado do teste de toxicidade aguda com amostras de esgoto da ETE-Araraquara antes e após a desinfecção com PAA e radiação UV, coletadas em 26/4/2004, utilizando D. similis como organismo-teste (48h de exposição).

\begin{tabular}{|c|c|c|c|c|c|c|c|c|c|c|c|c|c|}
\hline \multirow{2}{*}{ Amostras } & \multirow{2}{*}{ [PAA] ou Dr } & \multirow{2}{*}{$\begin{array}{l}\text { Residual de } \\
\text { PAA (mg/L) }\end{array}$} & \multicolumn{2}{|c|}{ Imobilidade } & \multirow{2}{*}{$\begin{array}{l}\text { Efeito } \\
\text { Tóxico }\end{array}$} & \multicolumn{2}{|c|}{$\mathrm{pH}$} & \multicolumn{2}{|c|}{ Cond. $(\mu \mathrm{S} / \mathrm{cm})$} & \multicolumn{2}{|c|}{ Dureza (mg/L) } & \multicolumn{2}{|c|}{ OD (mg/L) } \\
\hline & & & Total & $\%$ & & Inicial & Final & Inicial & Final & Inicial & Final & Inicial & Final \\
\hline Controle & & & 1 & 5 & & 7,60 & 7,96 & 186,0 & 203,0 & 44 & 42 & 7,2 & 7,0 \\
\hline Efluente & & & 0 & 0 & NT & 7,61 & 8,21 & 613,0 & 534,0 & 52 & 54 & 6,0 & 6,1 \\
\hline PAA & $5 \mathrm{mg} / \mathrm{L}, 40 \mathrm{~min}$. & 0,9226 & 10 & 50 & $\mathbf{T}$ & 7,63 & 7,67 & 646,0 & 637,0 & 54 & 56 & 6,7 & 7,0 \\
\hline PAA & $10 \mathrm{mg} / \mathrm{L}, 20 \mathrm{~min}$ & 0,9525 & 13 & 65 & $\mathbf{T}$ & 7,39 & 7,67 & 645,0 & 577,0 & 56 & 54 & 7,1 & 6,8 \\
\hline PAA & $10 \mathrm{mg} / \mathrm{L}, 40 \mathrm{~min}$ & 0,9898 & 11 & 55 & $\mathbf{T}$ & 7,46 & 7,77 & 646,0 & 639,0 & 56 & 54 & 7,8 & 6,6 \\
\hline UV & $36,46 \mathrm{mWs} / \mathrm{cm}^{2}$ & & 0 & 0 & NT & 7,85 & 8,18 & 608,0 & 561,0 & 52 & 48 & 7,5 & 6,2 \\
\hline UV & $145,85 \mathrm{mWs} / \mathrm{cm}^{2}$ & & 0 & 0 & NT & 7,90 & 8,19 & 606,0 & 549,0 & 52 & 48 & 7,5 & 6,2 \\
\hline
\end{tabular}

Tabela A-I.6. Resultado do teste de toxicidade aguda com amostras de esgoto da ETE-Araraquara antes e após a desinfecção com PAA e radiação UV, coletadas em 26/4/2004, utilizando D. rerio como organismo-teste (96h de exposição).

\begin{tabular}{|c|c|c|c|c|c|c|c|c|c|c|c|c|c|}
\hline \multirow{2}{*}{ Amostras } & \multirow{2}{*}{ [PAA] ou Dr } & \multirow{2}{*}{$\begin{array}{l}\text { Residual de } \\
\text { PAA (mg/L) }\end{array}$} & \multicolumn{2}{|c|}{ Mortalidade } & \multirow{2}{*}{$\begin{array}{l}\text { Efeito } \\
\text { Tóxico }\end{array}$} & \multicolumn{2}{|c|}{$\mathrm{pH}$} & \multicolumn{2}{|c|}{ Cond. $(\mu \mathrm{S} / \mathrm{cm})$} & \multicolumn{2}{|c|}{ Dureza (mg/L) } & \multicolumn{2}{|c|}{ OD (mg/L) } \\
\hline & & & Total & $\%$ & & Inicial & Final & Inicial & Final & Inicial & Final & Inicial & Final \\
\hline Controle & & & 0 & 0 & & 7,60 & 7,53 & 186,0 & 174,1 & 44 & 42 & 7,2 & 6,7 \\
\hline Efluente & & & 4 & 26,6 & $\mathbf{T}$ & 7,61 & 7,94 & 613,0 & 614,0 & 52 & 52 & 6,0 & 6,1 \\
\hline PAA & $5 \mathrm{mg} / \mathrm{L}, 40 \mathrm{~min}$. & 0,9226 & 5 & 33,3 & $\mathbf{T}$ & 7,63 & 7,94 & 646,0 & 605,0 & 54 & 56 & 6,7 & 4,7 \\
\hline PAA & 10 mg/L, $20 \mathrm{~min}$ & 0,9525 & 7 & 46,6 & $\mathbf{T}$ & 7,39 & 7,99 & 645,0 & 585,0 & 56 & 54 & 7,1 & 4,1 \\
\hline PAA & $10 \mathrm{mg} / \mathrm{L}, 40 \mathrm{~min}$. & 0,9898 & 11 & 73,3 & $\mathbf{T}$ & 7,46 & 7,85 & 646,0 & 605,0 & 56 & 54 & 7,8 & 3,9 \\
\hline UV & $36,46 \mathrm{mWs} / \mathrm{cm}^{2}$ & & 11 & 73,3 & $\mathbf{T}$ & 7,85 & 7,79 & 608,0 & 653,0 & 52 & 46 & 7,5 & 3,8 \\
\hline UV & $145,85 \mathrm{mWs} / \mathrm{cm}^{2}$ & & 12 & 80 & $\mathbf{T}$ & 7,90 & 7,92 & 606,0 & 621,0 & 52 & 46 & 7,5 & 3,6 \\
\hline
\end{tabular}

Dr = Dose recebida de radiação UV. $\quad \mathrm{NT}=$ Não Tóxico $\quad \mathrm{T}=$ Tóxico 
Tabela A-I.7. Resultado do teste de toxicidade crônica com amostras de esgoto da ETE-Araraquara antes e após a desinfecção com PAA e radiação UV, coletadas em 26/4/2004, utilizando C. xanthus como organismo-teste (168h de exposição).

\begin{tabular}{|c|c|c|c|c|c|c|c|c|c|c|c|c|c|}
\hline \multirow{2}{*}{ Amostras } & \multirow{2}{*}{ [PAA] ou Dr } & \multirow{2}{*}{$\begin{array}{l}\text { Residual de } \\
\text { PAA (mg/L) }\end{array}$} & \multicolumn{2}{|c|}{ Mortalidade } & \multirow{2}{*}{$\begin{array}{l}\text { Efeito } \\
\text { Tóxico }\end{array}$} & \multicolumn{2}{|c|}{$\mathrm{pH}$} & \multicolumn{2}{|c|}{ Cond. $(\mu S / \mathrm{cm})$} & \multicolumn{2}{|c|}{ Dureza (mg/L) } & \multicolumn{2}{|c|}{ OD (mg/L) } \\
\hline & & & Total & $\%$ & & Inicial & Final & Inicial & Final & Inicial & Final & Inicial & Final \\
\hline Controle & & & 0 & 0 & & 7,60 & 7,61 & 186,0 & 176,0 & 44 & 40 & 7,2 & 7,1 \\
\hline Efluente & & & 0 & 0 & NT & 7,61 & 8,16 & 613,0 & 583,0 & 52 & 44 & 6,0 & 6,4 \\
\hline PAA & $5 \mathrm{mg} / \mathrm{L}, 40 \mathrm{~min}$. & 0,9226 & 0 & 0 & NT & 7,63 & 8,31 & 646,0 & 575,0 & 54 & 40 & 6,7 & 6,8 \\
\hline PAA & $10 \mathrm{mg} / \mathrm{L}, 20 \mathrm{~min}$ & 0,9525 & 0 & 0 & NT & 7,39 & 8,36 & 645,0 & 571,0 & 56 & 44 & 7,1 & 6,0 \\
\hline PAA & 10 mg/L, $40 \mathrm{~min}$. & 0,9898 & 0 & 0 & NT & 7,46 & 8,33 & 646,0 & 568,0 & 56 & 42 & 7,8 & 6,3 \\
\hline UV & $36,46 \mathrm{mWs} / \mathrm{cm}^{2}$ & & 0 & 0 & NT & 7,85 & 8,22 & 608,0 & 583,0 & 52 & 46 & 7,5 & 6,8 \\
\hline UV & $145,85 \mathrm{mWs} / \mathrm{cm}^{2}$ & & 1 & 10 & NT & 7,90 & 8,25 & 606,0 & 581,0 & 52 & 46 & 7,5 & 6,6 \\
\hline
\end{tabular}

Tabela A-I.8. Resultado do teste de toxicidade aguda com amostras de esgoto da ETE-Araraquara antes e após a desinfecção com PAA e radiação UV, coletadas em 26/4/2004, utilizando C. silvestrii como organismo-teste (48h de exposição).

\begin{tabular}{|c|c|c|c|c|c|c|c|c|c|}
\hline \multirow{2}{*}{ Amostras } & \multirow{2}{*}{ [PAA] ou $\mathrm{Dr}$} & \multirow{2}{*}{$\begin{array}{l}\text { Residual de } \\
\text { PAA (mg/L) }\end{array}$} & \multicolumn{2}{|c|}{ Imobilidade } & \multirow{2}{*}{$\begin{array}{l}\text { Efeito } \\
\text { Tóxico }\end{array}$} & \multicolumn{2}{|c|}{$\mathrm{pH}$} & \multicolumn{2}{|c|}{ Cond. $(\mu \mathrm{S} / \mathrm{cm})$} \\
\hline & & & Total & $\%$ & & Inicial & Final & Inicial & Final \\
\hline Controle & & & 0 & 0 & & 7,60 & 7,58 & 186,0 & 175,9 \\
\hline Efluente & & & 5 & 50 & $\mathbf{T}$ & 7,61 & 7,61 & 613,0 & 637,0 \\
\hline PAA & $5 \mathrm{mg} / \mathrm{L}, 40 \mathrm{~min}$. & 0,9226 & 10 & 100 & $\mathbf{T}$ & 7,63 & 7,69 & 646,0 & 639,0 \\
\hline PAA & $10 \mathrm{mg} / \mathrm{L}, 20 \mathrm{~min}$ & 0,9525 & 10 & 100 & $\mathbf{T}$ & 7,39 & 7,60 & 645,0 & 577,0 \\
\hline PAA & $10 \mathrm{mg} / \mathrm{L}, 40 \mathrm{~min}$ & 0,9898 & 10 & 100 & $\mathbf{T}$ & 7,46 & 7,86 & 646,0 & 562,0 \\
\hline UV & $36,46 \mathrm{mWs} / \mathrm{cm}^{2}$ & & 7 & 70 & $\mathbf{T}$ & 7,85 & 8,42 & 608,0 & 568,0 \\
\hline UV & $145,85 \mathrm{mWs} / \mathrm{cm}^{2}$ & & 9 & 90 & $T$ & 7,90 & 8,45 & 606,0 & 549,0 \\
\hline
\end{tabular}

Dr $=$ Dose recebida de radiação UV. $\quad \mathrm{NT}=$ Não Tóxico $\quad \mathrm{T}=$ Tóxico 
Tabela A-I.9. Resultado do teste de toxicidade aguda com amostras de esgoto da ETE-Araraquara antes e após a desinfecção com PAA e radiação UV, coletadas em 26/4/2004, utilizando $A$. cepa como organismo-teste (72h de exposição).

\begin{tabular}{|c|c|c|c|c|c|c|c|c|c|c|c|c|c|}
\hline \multirow{2}{*}{ Amostras } & \multirow{2}{*}{ [PAA] ou Dr } & \multirow{2}{*}{$\begin{array}{l}\text { Residual de } \\
\text { PAA (mg/L) }\end{array}$} & \multirow{2}{*}{$\begin{array}{l}C * \\
(\%)\end{array}$} & \multirow{2}{*}{$\begin{array}{c}\text { Inibição ** } \\
(\%)\end{array}$} & \multirow{2}{*}{$\begin{array}{l}\text { Efeito } \\
\text { Tóxico }\end{array}$} & \multicolumn{2}{|c|}{$\mathrm{pH}$} & \multicolumn{2}{|c|}{ Cond. $(\mu S / \mathrm{cm})$} & \multicolumn{2}{|c|}{ Dureza (mg/L) } & \multicolumn{2}{|c|}{ OD (mg/L) } \\
\hline & & & & & & Inicial & Final & Inicial & Final & Inicial & Final & Inicial & Final \\
\hline Controle & & & 100,0 & 0 & & 7,60 & 5,84 & 186,0 & 359,0 & 44 & 36 & 7,2 & 1,3 \\
\hline Efluente & & & 55,9 & 44,1 & $\mathbf{T}$ & 7,61 & 6,68 & 613,0 & 606,0 & 52 & 52 & 6,0 & 0,8 \\
\hline PAA & $5 \mathrm{mg} / \mathrm{L}, 40 \mathrm{~min}$. & 0,9226 & 71,3 & 28,7 & $\mathbf{T}$ & 7,63 & 6,53 & 646,0 & 604,0 & 54 & 54 & 6,7 & 1,0 \\
\hline PAA & $10 \mathrm{mg} / \mathrm{L}, 20 \mathrm{~min}$ & 0,9525 & 79,0 & 21,0 & NT & 7,39 & 6,53 & 645,0 & 571,0 & 56 & 52 & 7,1 & 0,6 \\
\hline PAA & $10 \mathrm{mg} / \mathrm{L}, 40 \mathrm{~min}$. & 0,9898 & 49,6 & 50,4 & $\mathbf{T}$ & 7,46 & 6,58 & 646,0 & 590,0 & 56 & 50 & 7,8 & 0,5 \\
\hline UV & $36,46 \mathrm{mWs} / \mathrm{cm}^{2}$ & & 41,2 & 58,8 & $\mathbf{T}$ & 7,85 & 6,68 & 608,0 & 615,0 & 52 & 52 & 7,5 & 0,3 \\
\hline UV & $145,85 \mathrm{mWs} / \mathrm{cm}^{2}$ & & 40,4 & 59,6 & $\mathbf{T}$ & 7,90 & 6,53 & 606,0 & 607,0 & 52 & 52 & 7,5 & 0,2 \\
\hline
\end{tabular}

* Crescimento relativo (em relação ao controle). ${ }^{* *}$ Inibição do crescimento em relação ao controle.

Tabela A-I.10. Toxicidade do efluente da ETE-Araraquara coletado em 26/04/04 antes e após a desinfecção com PAA e UV e eficiência de remoção de Escherichia coli.

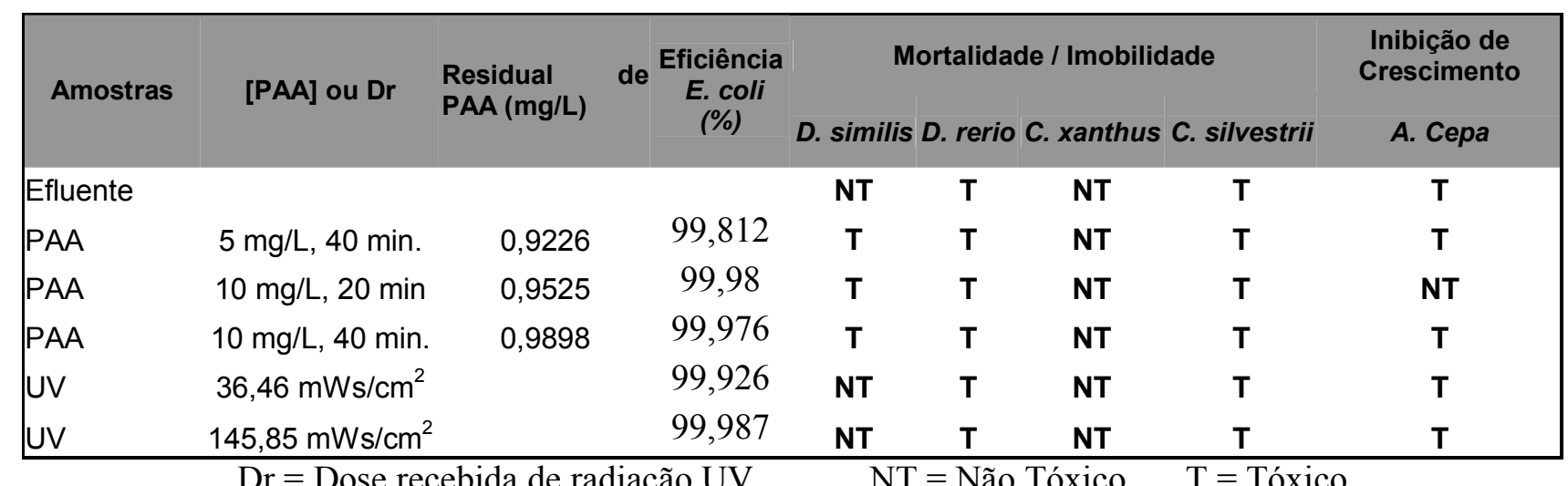

Dr $=$ Dose recebida de radiação UV. $\quad$ NT $=$ Não Tóxico $\quad T=$ Tóxico 
Tabela A-I.11. Resultado do teste de toxicidade aguda com amostras de esgoto da ETE-Araraquara antes e após a desinfecção com PAA e radiação UV, coletadas em 5/7/2004, utilizando D. similis como organismo-teste (48h de exposição).

\begin{tabular}{|c|c|c|c|c|c|c|c|c|c|c|c|c|c|}
\hline \multirow{2}{*}{ Amostras } & \multirow{2}{*}{ [PAA] ou Dr } & \multirow{2}{*}{$\begin{array}{l}\text { Residual } \\
\text { de PAA } \\
\text { (mg/L) }\end{array}$} & \multicolumn{2}{|c|}{ Imobilidade } & \multirow{2}{*}{$\begin{array}{l}\text { Efeito } \\
\text { Tóxico }\end{array}$} & \multicolumn{2}{|c|}{$\mathrm{pH}$} & \multicolumn{2}{|c|}{ Cond. $(\mu \mathrm{S} / \mathrm{cm})$} & \multicolumn{2}{|c|}{ Dureza (mg/L) } & \multicolumn{2}{|c|}{ OD (mg/L) } \\
\hline & & & Total & $\%$ & & Inicial & Final & Inicial & Final & Inicial & Final & Inicial & Final \\
\hline Controle & & & 0 & 0 & & 7,60 & 7,73 & 146,8 & 169,7 & 44 & 40 & 7,2 & 7,0 \\
\hline Efluente & & & 0 & 0 & NT & 7,42 & 7,05 & 573,0 & 487,0 & 60 & 66 & 6,8 & 5,4 \\
\hline PAA & $5 \mathrm{mg} / \mathrm{L}, 20 \mathrm{~min}$ & 0,8667 & 0 & 0 & NT & 7,38 & 7,32 & 594,0 & 532,0 & 64 & 62 & 7,0 & 5,8 \\
\hline PAA & $5 \mathrm{mg} / \mathrm{L}, 40 \mathrm{~min}$ & 0,9040 & 0 & 0 & NT & 7,34 & 7,33 & 608,0 & 522,0 & 62 & 66 & 6,6 & 5,9 \\
\hline PAA & $10 \mathrm{mg} / \mathrm{L}, 20 \mathrm{~min}$ & 0,8443 & 7 & 35 & $\mathbf{T}$ & 7,26 & 8,08 & 597,0 & 564,0 & 64 & 62 & 6,8 & 6,4 \\
\hline PAA & $10 \mathrm{mg} / \mathrm{L}, 40 \mathrm{~min}$. & 0,9823 & 20 & 100 & $\mathbf{T}$ & 7,26 & 8,08 & 603,0 & 565,0 & 62 & 64 & 6,9 & 6,4 \\
\hline UV & $31,54 \mathrm{mWs} / \mathrm{cm}^{2}$ & & 2 & 10 & NT & 7,57 & 7,73 & 575,0 & 532,0 & 58 & 64 & 6,2 & 5,5 \\
\hline UV & $126,18 \mathrm{mWs} / \mathrm{cm}^{2}$ & & 0 & 0 & NT & 7,59 & 7,94 & 576,0 & 521,0 & 60 & 60 & 6,5 & 5,5 \\
\hline
\end{tabular}

Tabela A-I.12. Resultado do teste de toxicidade aguda com amostras de esgoto da ETE-Araraquara antes e após a desinfecção com PAA e radiação UV, coletadas em 5/7/2004, utilizando D. rerio como organismo-teste (96h de exposição).

\begin{tabular}{|c|c|c|c|c|c|c|c|c|c|c|c|c|c|}
\hline \multirow{2}{*}{ Amostras } & \multirow{2}{*}{ [PAA] ou $\mathrm{Dr}$} & \multirow{2}{*}{$\begin{array}{l}\text { Residual } \\
\text { de PAA } \\
\text { (mg/L) }\end{array}$} & \multicolumn{2}{|c|}{ Mortalidade } & \multirow{2}{*}{$\begin{array}{l}\text { Efeito } \\
\text { Tóxico }\end{array}$} & \multicolumn{2}{|c|}{$\overline{\mathrm{pH}}$} & \multicolumn{2}{|c|}{ Cond. $(\mu \mathrm{S} / \mathrm{cm})$} & \multicolumn{2}{|c|}{ Dureza (mg/L) } & \multicolumn{2}{|c|}{ OD (mg/L) } \\
\hline & & & Total & $\%$ & & Inicial & Final & Inicial & Final & Inicial & Final & Inicial & Final \\
\hline Controle & & & 0 & 0 & & 7,60 & 7,71 & 146,8 & 198,2 & 44 & 50 & 7,2 & 7,0 \\
\hline Efluente & & & 0 & 0 & NT & 7,42 & 7,09 & 573,0 & 527,0 & 60 & 66 & 6,8 & 4,8 \\
\hline PAA & $5 \mathrm{mg} / \mathrm{L}, 20 \mathrm{~min}$. & 0,8667 & 0 & 0 & NT & 7,38 & 7,00 & 545,0 & 558,0 & 64 & 62 & 7,0 & 4,2 \\
\hline PAA & $5 \mathrm{mg} / \mathrm{L}, 40 \mathrm{~min}$ & 0,9040 & 1 & 6,66 & NT & 7,34 & 7,28 & 549,0 & 557,0 & 62 & 66 & 6,6 & 4,3 \\
\hline PAA & 10 mg/L, $20 \mathrm{~min}$ & 0,8443 & 1 & 6,66 & NT & 7,26 & 7,87 & 568,0 & 585,0 & 64 & 62 & 6,8 & 5,7 \\
\hline PAA & $10 \mathrm{mg} / \mathrm{L}, 40 \mathrm{~min}$ & 0,9823 & 0 & 0 & NT & 7,26 & 7,88 & 577,0 & 595,0 & 62 & 64 & 6,9 & 6,1 \\
\hline UV & $31,54 \mathrm{mWs} / \mathrm{cm}^{2}$ & & 0 & 0 & NT & 7,57 & 7,73 & 575,0 & 563,0 & 58 & 64 & 6,2 & 5,3 \\
\hline UV & $126,18 \mathrm{mWs} / \mathrm{cm}^{2}$ & & 0 & 0 & NT & 7,59 & 7,94 & 576,0 & 566,0 & 60 & 70 & 6,5 & 5,9 \\
\hline
\end{tabular}

Dr = Dose recebida de radiação UV. $\quad$ NT = Não Tóxico $\quad$ T = Tóxico 
Tabela A-I.13. Resultado do teste de toxicidade crônico com amostras de esgoto da ETE-Araraquara antes e após a desinfecção com PAA e radiação UV, coletadas em 5/7/2004, utilizando C. xanthus como organismo-teste (168h de exposição).

\begin{tabular}{|c|c|c|c|c|c|c|c|c|c|c|c|c|c|}
\hline \multirow{2}{*}{ Amostras } & \multirow{2}{*}{ [PAA] ou Dr } & \multirow{2}{*}{$\begin{array}{c}\text { Residual } \\
\text { de PAA } \\
\text { (mg/L) }\end{array}$} & \multicolumn{2}{|c|}{ Mortalidade } & \multirow{2}{*}{$\begin{array}{l}\text { Efeito } \\
\text { Tóxico }\end{array}$} & \multicolumn{2}{|c|}{$\mathrm{pH}$} & \multicolumn{2}{|c|}{ Cond. $(\mu \mathrm{S} / \mathrm{cm})$} & \multicolumn{2}{|c|}{ Dureza (mg/L) } & \multicolumn{2}{|c|}{ OD (mg/L) } \\
\hline & & & Total & $\%$ & & Inicial & Final & Inicial & Final & Inicial & Final & Inicial & Final \\
\hline Controle & & & 1 & 10 & & 7,60 & 7,35 & 146,8 & 202,0 & 44 & 46 & 7,2 & 5,9 \\
\hline Efluente & & & 0 & 0 & NT & 7,42 & 7,57 & 573,0 & 603,0 & 60 & 60 & 6,8 & 3,4 \\
\hline PAA & $5 \mathrm{mg} / \mathrm{L}, 20 \mathrm{~min}$. & 0,8667 & 1 & 10 & NT & 7,38 & 7,90 & 545,0 & 594,0 & 64 & 66 & 7,0 & 5,1 \\
\hline PAA & $5 \mathrm{mg} / \mathrm{L}, 40 \mathrm{~min}$. & 0,9040 & 1 & 10 & NT & 7,34 & 7,82 & 549,0 & 596,0 & 62 & 66 & 6,6 & 5,2 \\
\hline PAA & $10 \mathrm{mg} / \mathrm{L}, 20 \mathrm{~min}$ & 0,8443 & 1 & 10 & NT & 7,26 & 7,81 & 568,0 & 605,0 & 64 & 64 & 6,8 & 5,0 \\
\hline PAA & $10 \mathrm{mg} / \mathrm{L}, 40 \mathrm{~min}$. & 0,9823 & 0 & 0 & NT & 7,26 & 7,89 & 577,0 & 599,0 & 62 & 66 & 6,9 & 5,2 \\
\hline UV & $31,54 \mathrm{mWs} / \mathrm{cm}^{2}$ & & 0 & 0 & NT & 7,57 & 7,64 & 575,0 & 615,0 & 58 & 60 & 6,2 & 3,3 \\
\hline UV & $126,18 \mathrm{mWs} / \mathrm{cm}^{2}$ & & 1 & 10 & NT & 7,59 & 7,61 & 576,0 & 631,0 & 60 & 60 & 6,5 & 3,7 \\
\hline
\end{tabular}

Tabela A-I.14. Resultado do teste de toxicidade crônico com amostras de esgoto da ETE-Araraquara antes e após a desinfecção com PAA e radiação UV, coletadas em 5/7/2004, utilizando C. silvestrii como organismo-teste (48h de exposição).

\begin{tabular}{|c|c|c|c|c|c|c|c|c|c|c|c|c|c|}
\hline \multirow{2}{*}{ Amostras } & \multirow{2}{*}{ [PAA] ou Dr } & \multirow{2}{*}{$\begin{array}{l}\text { Residual } \\
\text { de PAA } \\
\text { (mg/L) }\end{array}$} & \multicolumn{2}{|c|}{ Imobilidade } & \multirow{2}{*}{$\begin{array}{l}\text { Efeito } \\
\text { Tóxico }\end{array}$} & \multicolumn{2}{|c|}{$\mathrm{pH}$} & \multicolumn{2}{|c|}{ Cond. $(\mu S / \mathrm{cm})$} & \multicolumn{2}{|c|}{ Dureza (mg/L) } & \multicolumn{2}{|c|}{ OD (mg/L) } \\
\hline & & & Total & $\%$ & & Inicial & Final & Inicial & Final & Inicial & Final & Inicial & Final \\
\hline Controle & & & 0 & 0 & & 7,60 & 7,65 & 146,8 & 152,8 & 48 & 44 & 7,2 & 7,2 \\
\hline Efluente & & & 10 & 100 & $\mathbf{T}$ & 7,42 & 7,07 & 573,0 & 520,0 & 60 & 60 & 6,8 & 4,8 \\
\hline PAA & $5 \mathrm{mg} / \mathrm{L}, 20 \mathrm{~min}$. & 0,8667 & 9 & 90 & $\mathbf{T}$ & 7,38 & 7,25 & 545,0 & 526,0 & 64 & 66 & 7,0 & 5,3 \\
\hline PAA & $5 \mathrm{mg} / \mathrm{L}, 40 \mathrm{~min}$. & 0,9040 & 10 & 100 & $\mathbf{T}$ & 7,34 & 7,39 & 549,0 & 527,0 & 62 & 66 & 6,6 & 5,2 \\
\hline PAA & $10 \mathrm{mg} / \mathrm{L}, 20 \mathrm{~min}$ & 0,8443 & 9 & 90 & $\mathbf{T}$ & 7,26 & 8,11 & 568,0 & 558,0 & 64 & 64 & 6,8 & 6,4 \\
\hline PAA & $10 \mathrm{mg} / \mathrm{L}, 40 \mathrm{~min}$ & 0,9823 & 9 & 90 & $\mathbf{T}$ & 7,26 & 8,10 & 577,0 & 558,0 & 62 & 66 & 6,9 & 6,3 \\
\hline UV & $31,54 \mathrm{mWs} / \mathrm{cm}^{2}$ & & 9 & 90 & $\mathbf{T}$ & 7,57 & 7,66 & 575,0 & 562,0 & 58 & 60 & 6,2 & 3,0 \\
\hline UV & $126,18 \mathrm{mWs} / \mathrm{cm}^{2}$ & & 10 & 100 & $\mathbf{T}$ & 7,59 & 7,88 & 576,0 & 562,0 & 60 & 60 & 6,5 & 5,5 \\
\hline
\end{tabular}

Dr = Dose recebida de radiação UV. $\quad$ NT = Não Tóxico $\quad$ T = Tóxico 
Tabela A-I.15. Resultado do teste de toxicidade aguda com amostras de esgoto da ETE-Araraquara antes e após a desinfecção com PAA e radiação UV, coletadas em 5/7/2004, utilizando A. cepa como organismo-teste (72h de exposição).

\begin{tabular}{|c|c|c|c|c|c|c|c|c|c|c|c|c|c|}
\hline \multirow{2}{*}{ Amostras } & \multirow{2}{*}{ [PAA] ou Dr } & \multirow{2}{*}{$\begin{array}{c}\text { Residual } \\
\text { de PAA } \\
\text { (mg/L) }\end{array}$} & \multirow{2}{*}{$\begin{array}{l}\text { C* } \\
(\%)\end{array}$} & \multirow{2}{*}{$\begin{array}{c}\text { Inibição ** } \\
(\%)\end{array}$} & \multirow{2}{*}{$\begin{array}{l}\text { Efeito } \\
\text { Tóxico }\end{array}$} & \multicolumn{2}{|c|}{$\mathrm{pH}$} & \multicolumn{2}{|c|}{ Cond. $(\mu \mathrm{S} / \mathrm{cm})$} & \multicolumn{2}{|c|}{ Dureza (mg/L) } & \multicolumn{2}{|c|}{ OD (mg/L) } \\
\hline & & & & & & Inicial & Final & Inicial & Final & Inicial & Final & Inicial & Final \\
\hline Controle & & & 100,0 & 0 & & 7,60 & 6,50 & 146,8 & 147,4 & 48 & 44 & 7,2 & 4,5 \\
\hline Efluente & & & 72,7 & 27,3 & IT & 7,42 & 6,97 & 573,0 & 573,0 & 60 & 64 & 6,8 & 0,8 \\
\hline PAA & $5 \mathrm{mg} / \mathrm{L}, 20 \mathrm{~min}$ & 0,8667 & 75,0 & 25,0 & IT & 7,38 & 6,62 & 545,0 & 527,0 & 64 & 66 & 7,0 & 1,2 \\
\hline PAA & $5 \mathrm{mg} / \mathrm{L}, 40 \mathrm{~min}$. & 0,9040 & 70,6 & 29,4 & IT & 7,34 & 6,48 & 549,0 & 514,0 & 62 & 64 & 6,6 & 0,6 \\
\hline PAA & $10 \mathrm{mg} / \mathrm{L}, 20 \mathrm{~min}$ & 0,8443 & 70,9 & 29,1 & IT & 7,26 & 6,77 & 568,0 & 555,0 & 64 & 62 & 6,8 & 0,7 \\
\hline PAA & $10 \mathrm{mg} / \mathrm{L}, 40 \mathrm{~min}$. & 0,9823 & 62,8 & 37,2 & $\mathbf{T}$ & 7,26 & 6,78 & 577,0 & 551,0 & 62 & 60 & 6,9 & 1,0 \\
\hline UV & $31,54 \mathrm{mWs} / \mathrm{cm}^{2}$ & & 65,4 & 34,6 & $\mathbf{T}$ & 7,57 & 7,20 & 575,0 & 543,0 & 58 & 60 & 6,2 & 0,5 \\
\hline UV & $126,18 \mathrm{mWs} / \mathrm{cm}^{2}$ & & 55,5 & 44,5 & $\mathbf{T}$ & 7,59 & 7,45 & 576,0 & 560,0 & 60 & 60 & 6,5 & 1,3 \\
\hline
\end{tabular}

* Crescimento relativo (em relação ao controle). ** Inibição do crescimento em relação ao controle.

Tabela A-I.16. Toxicidade do efluente da ETE-Araraquara coletado em 5/7/04 antes e após a desinfecção com PAA e UV e eficiência de remoção de Escherichia coli.

\begin{tabular}{|c|c|c|c|c|c|c|c|c|}
\hline \multirow{2}{*}{ Amostras } & \multirow{2}{*}{ [PAA] ou Dr } & \multirow{2}{*}{$\begin{array}{c}\text { Residual } \\
\text { de PAA } \\
\text { (mg/L) }\end{array}$} & \multirow{2}{*}{$\begin{array}{c}\text { Eficiência } \\
\text { E. coli } \\
(\%)\end{array}$} & \multicolumn{4}{|c|}{ Mortalidade / Imobilidade } & \multirow{2}{*}{$\begin{array}{c}\begin{array}{c}\text { Inibição de } \\
\text { Crescimento }\end{array} \\
\text { A. Cepa }\end{array}$} \\
\hline & & & & D. similis & D. rerio & C. xanthus & C. silvestrii & \\
\hline Efluente & & & & NT & NT & NT & $\mathbf{T}$ & IT \\
\hline PAA & $5 \mathrm{mg} / \mathrm{L}, 20 \mathrm{~min}$ & 0,8667 & 99,901 & NT & NT & NT & $\mathbf{T}$ & IT \\
\hline PAA & $5 \mathrm{mg} / \mathrm{L}, 40 \mathrm{~min}$ & 0,9040 & 99,859 & NT & NT & NT & $\mathbf{T}$ & IT \\
\hline PAA & $10 \mathrm{mg} / \mathrm{L}, 20 \mathrm{~min}$ & 0,8443 & 99,999 & $\mathbf{T}$ & NT & NT & $\mathbf{T}$ & IT \\
\hline PAA & $10 \mathrm{mg} / \mathrm{L}, 40 \mathrm{~min}$. & 0,9823 & 99,762 & $\mathbf{T}$ & NT & NT & $\mathbf{T}$ & $\mathbf{T}$ \\
\hline UV & $31,54 \mathrm{mWs} / \mathrm{cm}^{2}$ & & 98,720 & NT & NT & NT & $\mathbf{T}$ & $\mathbf{T}$ \\
\hline UV & $126,18 \mathrm{mWs} / \mathrm{cm}^{2}$ & & 99,962 & NT & NT & NT & $\mathbf{T}$ & $\mathbf{T}$ \\
\hline
\end{tabular}


Tabela A-I.17. Resultado do teste de toxicidade aguda com amostras de esgoto da ETE-Araraquara antes e após a desinfecção com PAA, radiação UV, Ozônio e Cloro coletadas em 17/11/2004, utilizando D. similis como organismo-teste (48h de exposição).

\begin{tabular}{|c|c|c|c|c|c|c|c|c|c|c|c|c|}
\hline \multirow{2}{*}{ Amostras } & \multirow{2}{*}{ [ ] ou De ou Dr } & \multirow{2}{*}{$\begin{array}{c}\text { Residual } \\
\text { Livre (mg/L) }\end{array}$} & \multirow{2}{*}{$\begin{array}{c}\text { Residual } \\
\text { Total (mg/L) }\end{array}$} & \multicolumn{2}{|c|}{ Imobilidade } & \multirow{2}{*}{$\begin{array}{l}\text { Efeito } \\
\text { Tóxico }\end{array}$} & \multicolumn{2}{|c|}{$\mathrm{pH}$} & \multicolumn{2}{|c|}{ Cond. $(\mu \mathrm{S} / \mathrm{cm})$} & \multicolumn{2}{|c|}{ OD (mg/L) } \\
\hline & & & & Total & $\%$ & & Inicial & Final & Inicial & Final & Inicial & Final \\
\hline Controle & & & & 1 & 0,5 & & 7,61 & 8,00 & 144,7 & 198,5 & 7,2 & 7,1 \\
\hline Efluente & & & & 0 & 0 & NT & 7,78 & 7,35 & 604,0 & 619,0 & 5,6 & 4,8 \\
\hline PAA & $5 \mathrm{mg} / \mathrm{L}, 20 \mathrm{~min}$. & & 0,82568 & 0 & 0 & NT & 7,65 & 8,26 & 601,0 & 617,0 & 9,4 & 5,9 \\
\hline UV & $78,96 \mathrm{mWs} / \mathrm{cm}^{2}$ & & & 0 & 0 & NT & 7,91 & 8,26 & 596,0 & 609,0 & 7,1 & 6,2 \\
\hline Ozônio & $29,9 \mathrm{mg} / / \mathrm{L}$ & & 1,44 & 12 & 60 & $\mathbf{T}$ & 7,74 & 8,27 & 612,0 & 641,0 & 7,5 & 6,7 \\
\hline Ozônio & $45,15 \mathrm{mg} / / \mathrm{L}$ & & 1,56 & 16 & 80 & $\mathbf{T}$ & 7,89 & 8,30 & 614,0 & 659,0 & 7,8 & 6,5 \\
\hline Cloro & $2,5 \mathrm{mg} / \mathrm{L}, 20 \mathrm{~min}$. & 0,03648 & 0,19188 & 20 & 100 & $\mathbf{T}$ & 7,65 & 8,30 & 617,0 & 617,0 & 7,4 & 6,8 \\
\hline Cloro & $2,5 \mathrm{mg} / \mathrm{L}, 40 \mathrm{~min}$. & $<0,026$ & $<0,026$ & 17 & 85 & $\mathbf{T}$ & 7,61 & 8,31 & 617,0 & 617,0 & 7,4 & 7,0 \\
\hline Cloro & $7,0 \mathrm{mg} / \mathrm{L}, 20 \mathrm{~min}$. & 0,48714 & 2,92692 & 20 & 100 & $\mathbf{T}$ & 7,73 & 8,38 & 631,0 & 631,0 & 7,3 & 7,1 \\
\hline Cloro & $7,0 \mathrm{mg} / \mathrm{L}, 40 \mathrm{~min}$. & 0,17634 & 2,41928 & 20 & 100 & $\mathbf{T}$ & 7,66 & 8,39 & 629,0 & 629,0 & 7,6 & 7,2 \\
\hline
\end{tabular}

Tabela A-I.18. Resultado do teste de toxicidade aguda com amostras de esgoto da ETE-Araraquara antes e após a desinfecção com PAA, radiação UV, Ozônio e Cloro coletadas em 17/11/2004, utilizando D. rerio como organismo-teste (96h de exposição).

\begin{tabular}{|c|c|c|c|c|c|c|c|c|c|c|c|c|}
\hline \multirow{2}{*}{ Amostras } & \multirow{2}{*}{ [ ] ou De ou Dr } & \multirow{2}{*}{$\begin{array}{c}\text { Residual } \\
\text { Livre (mg/L) }\end{array}$} & \multirow{2}{*}{$\begin{array}{c}\text { Residual } \\
\text { Total (mg/L) }\end{array}$} & \multicolumn{2}{|c|}{ Mortalidade } & \multirow{2}{*}{$\begin{array}{l}\text { Efeito } \\
\text { Tóxico }\end{array}$} & \multicolumn{2}{|c|}{$\mathrm{pH}$} & \multicolumn{2}{|c|}{ Cond. $(\mu \mathrm{S} / \mathrm{cm})$} & \multicolumn{2}{|c|}{ OD (mg/L) } \\
\hline & & & & Total & $\%$ & & Inicial & Final & Inicial & Final & Inicial & Final \\
\hline Controle & & & & 1 & 6,66 & & 7,61 & 7,60 & 144,7 & 198,5 & 7,2 & 5,9 \\
\hline Efluente & & & & 7 & 20,0 & IT & 7,78 & 7,84 & 604,0 & 619,0 & 5,6 & 4,2 \\
\hline PAA & $5 \mathrm{mg} / \mathrm{L}, 20 \mathrm{~min}$. & & 0,82568 & 11 & 46,66 & $\mathbf{T}$ & 7,65 & 7,92 & 601,0 & 617,0 & 9,4 & 5,8 \\
\hline UV & $78,96 \mathrm{mWs} / \mathrm{cm}^{2}$ & & & 15 & 73,3 & $\mathbf{T}$ & 7,91 & 7,90 & 596,0 & 609,0 & 7,1 & 3,8 \\
\hline Ozônio & $29,9 \mathrm{mg} / / \mathrm{L}$ & & 1,44 & 13 & 86,6 & $\mathbf{T}$ & 7,74 & 7,96 & 612,0 & 641,0 & 7,5 & 5,0 \\
\hline Ozônio & $45,15 \mathrm{mg} / / \mathrm{L}$ & & 1,56 & 8 & 53,33 & $\mathbf{T}$ & 7,89 & 7,92 & 614,0 & 659,0 & 7,8 & 5,4 \\
\hline Cloro & 2,5 mg/L, $20 \mathrm{~min}$. & 0,03648 & 0,19188 & 15 & 100 & $\mathbf{T}$ & 7,65 & 7,92 & 617,0 & 617,0 & 7,4 & 6,8 \\
\hline Cloro & $2,5 \mathrm{mg} / \mathrm{L}, 40 \mathrm{~min}$. & $<0,026$ & $<0,026$ & 15 & 100 & $\mathbf{T}$ & 7,61 & 7,83 & 617,0 & 617,0 & 7,4 & 6,6 \\
\hline Cloro & $7,0 \mathrm{mg} / \mathrm{L}, 20 \mathrm{~min}$. & 0,48714 & 2,92692 & 15 & 100 & $\mathbf{T}$ & 7,73 & 7,93 & 631,0 & 631,0 & 7,3 & 6,6 \\
\hline Cloro & $7,0 \mathrm{mg} / \mathrm{L}, 40 \mathrm{~min}$. & 0,17634 & 2,41928 & 15 & 100 & $\mathbf{T}$ & 7,66 & 7,84 & 629,0 & 629,0 & 7,6 & 6,3 \\
\hline
\end{tabular}

De $=$ Dose efetiva de Ozônio. $\quad$ Dr $=$ Dose recebida de radiação UV. $\quad \mathrm{NT}=$ Não Tóxico $\quad$ IT $=$ Indícios de Toxicidade $\quad \mathrm{T}=$ Tóxico 
Tabela A-I.19. Resultado do teste de toxicidade aguda com amostras de esgoto da ETE-Araraquara antes e após a desinfecção com PAA, radiação UV, Ozônio e Cloro coletadas em 17/11/2004, utilizando C. xanthus como organismo-teste (168h de exposição).

\begin{tabular}{|c|c|c|c|c|c|c|c|c|c|c|c|c|}
\hline \multirow{2}{*}{ Amostras } & \multirow{2}{*}{ [ ] ou De ou Dr } & \multirow{2}{*}{$\begin{array}{l}\text { Residual } \\
\text { Livre (mg/L) }\end{array}$} & \multirow{2}{*}{$\begin{array}{l}\text { Residual } \\
\text { Total (mg/L) }\end{array}$} & \multicolumn{2}{|c|}{ Mortalidade } & \multirow{2}{*}{$\begin{array}{l}\text { Efeito } \\
\text { Tóxico }\end{array}$} & \multicolumn{2}{|c|}{$\mathrm{pH}$} & \multicolumn{2}{|c|}{ Cond. $(\mu \mathrm{S} / \mathrm{cm})$} & \multicolumn{2}{|c|}{ OD (mg/L) } \\
\hline & & & & Total & $\%$ & & Inicial & Final & Inicial & Final & Inicial & Final \\
\hline Controle & & & & 1 & 10 & & 7,61 & 7,22 & 144,7 & 196,4 & 7,2 & 5,1 \\
\hline Efluente & & & & 1 & 10 & NT & 7,78 & 7,69 & 604,0 & 590,0 & 5,6 & 4,2 \\
\hline PAA & $5 \mathrm{mg} / \mathrm{L}, 20 \mathrm{~min}$. & & 0,82568 & 1 & 10 & NT & 7,65 & 7,67 & 601,0 & 601,0 & 9,4 & 4,0 \\
\hline UV & $78,96 \mathrm{mWs} / \mathrm{cm}^{2}$ & & & 1 & 10 & NT & 7,91 & 7,86 & 596,0 & 627,0 & 7,1 & 4,2 \\
\hline Ozônio & $29,9 \mathrm{mg} / / \mathrm{L}$ & & 1,44 & 0 & 0 & NT & 7,74 & 7,82 & 612,0 & 641,0 & 7,5 & 3,7 \\
\hline Ozônio & $45,15 \mathrm{mg} / / \mathrm{L}$ & & 1,56 & 0 & 0 & NT & 7,89 & 7,84 & 614,0 & 648,0 & 7,8 & 4,4 \\
\hline Cloro & $2,5 \mathrm{mg} / \mathrm{L}, 20 \mathrm{~min}$. & 0,03648 & 0,19188 & 1 & 10 & NT & 7,65 & 7,60 & 617,0 & 654,0 & 7,4 & 4,1 \\
\hline Cloro & $2,5 \mathrm{mg} / \mathrm{L}, 40 \mathrm{~min}$. & $<0,026$ & $<0,026$ & 0 & 0 & NT & 7,61 & 7,62 & 617,0 & 662,0 & 7,4 & 6,0 \\
\hline Cloro & 7,0 mg/L, $20 \mathrm{~min}$. & 0,48714 & 2,92692 & 9 & 90 & $\mathbf{T}$ & 7,73 & 7,49 & 631,0 & 643,0 & 7,3 & 5,9 \\
\hline Cloro & $7,0 \mathrm{mg} / \mathrm{L}, 40 \mathrm{~min}$. & 0,17634 & 2,41928 & 5 & 50 & $\mathbf{T}$ & 7,66 & 7,79 & 629,0 & 637,0 & 7,6 & 5,5 \\
\hline
\end{tabular}

Tabela A-I.20. Resultado do teste de toxicidade aguda com amostras de esgoto da ETE-Araraquara antes e após a desinfecção com PAA, radiação UV, Ozônio e Cloro coletadas em 17/11/2004, utilizando C. silvestrii como organismo-teste (48h de exposição).

\begin{tabular}{|c|c|c|c|c|c|c|c|c|c|c|c|c|}
\hline \multirow{2}{*}{ Amostras } & \multirow{2}{*}{ [ ] ou De ou Dr } & \multirow{2}{*}{$\begin{array}{c}\text { Residual } \\
\text { Livre (mg/L) }\end{array}$} & \multirow{2}{*}{$\begin{array}{c}\text { Residual } \\
\text { Total (mg/L) }\end{array}$} & \multicolumn{2}{|c|}{ Imobilidade } & \multirow{2}{*}{$\begin{array}{l}\text { Efeito } \\
\text { Tóxico }\end{array}$} & \multicolumn{2}{|c|}{ pH } & \multicolumn{2}{|c|}{ Cond. $(\mu \mathrm{S} / \mathrm{cm})$} & \multicolumn{2}{|c|}{$O D(\mathrm{mg} / \mathrm{L})$} \\
\hline & & & & Total & $\%$ & & Inicial & Final & Inicial & Final & Inicial & Final \\
\hline Controle & & & & 0 & 0 & & 7,61 & 8,00 & 144,7 & 198,5 & 7,2 & 7,1 \\
\hline Efluente & & & & 6 & 60 & $\mathbf{T}$ & 7,78 & 7,35 & 604,0 & 619,0 & 5,6 & 4,8 \\
\hline PAA & $5 \mathrm{mg} / \mathrm{L}, 20 \mathrm{~min}$. & & 0,82568 & 9 & 90 & $\mathbf{T}$ & 7,65 & 7,86 & 601,0 & 617,0 & 9,4 & 5,9 \\
\hline UV & $78,96 \mathrm{mWs} / \mathrm{cm}^{2}$ & & & 9 & 90 & $\mathbf{T}$ & 7,91 & 8,18 & 596,0 & 609,0 & 7,1 & 6,2 \\
\hline Ozônio & $29,9 \mathrm{mg} / / \mathrm{L}$ & & 1,44 & 10 & 100 & $\mathbf{T}$ & 7,74 & 8,27 & 612,0 & 641,0 & 7,5 & 6,7 \\
\hline Ozônio & $45,15 \mathrm{mg} / / \mathrm{L}$ & & 1,56 & 10 & 100 & $\mathbf{T}$ & 7,89 & 8,30 & 614,0 & 659,0 & 7,8 & 6,5 \\
\hline Cloro & $2,5 \mathrm{mg} / \mathrm{L}, 20 \mathrm{~min}$. & 0,03648 & 0,19188 & 10 & 100 & $\mathbf{T}$ & 7,65 & 8,30 & 617,0 & 617,0 & 7,4 & 6,8 \\
\hline Cloro & $2,5 \mathrm{mg} / \mathrm{L}, 40 \mathrm{~min}$. & $<0,026$ & $<0,026$ & 10 & 100 & $\mathbf{T}$ & 7,61 & 8,31 & 617,0 & 617,0 & 7,4 & 7,0 \\
\hline Cloro & $7,0 \mathrm{mg} / \mathrm{L}, 20 \mathrm{~min}$. & 0,48714 & 2,92692 & 10 & 100 & $\mathbf{T}$ & 7,73 & 8,38 & 631,0 & 631,0 & 7,3 & 7,1 \\
\hline Cloro & $7,0 \mathrm{mg} / \mathrm{L}, 40 \mathrm{~min}$. & 0,17634 & 2,41928 & 10 & 100 & $\mathbf{T}$ & 7,66 & 8,39 & 629,0 & 629,0 & 7,6 & 7,2 \\
\hline
\end{tabular}

De = Dose efetiva de Ozônio. $\quad \mathrm{Dr}=$ Dose recebida de radiação UV. $\quad$ NT = Não Tóxico $\quad \mathrm{T}=$ Tóxico 
Tabela A-I.21. Resultado do teste de toxicidade aguda com amostras de esgoto da ETE-Araraquara antes e após a desinfecção com PAA, radiação UV, Ozônio e Cloro coletadas em 17/11/2004, utilizando A. cepa como organismo-teste (72h de exposição).

\begin{tabular}{|c|c|c|c|c|c|c|c|c|c|c|c|c|}
\hline \multirow{2}{*}{ Amostras } & \multirow{2}{*}{ [ ] ou De ou Dr } & \multirow{2}{*}{$\begin{array}{c}\text { Residual } \\
\text { Livre (mg/L) }\end{array}$} & \multirow{2}{*}{$\begin{array}{c}\text { Residual } \\
\text { Total (mg/L) }\end{array}$} & \multirow{2}{*}{$\begin{array}{l}\text { C * } \\
\text { (\%) }\end{array}$} & \multirow{2}{*}{$\begin{array}{c}\text { Inibição ** } \\
(\%)\end{array}$} & \multirow{2}{*}{$\begin{array}{l}\text { Efeito } \\
\text { Tóxico }\end{array}$} & \multicolumn{2}{|c|}{$\mathrm{pH}$} & \multicolumn{2}{|c|}{ Cond. $(\mu \mathrm{S} / \mathrm{cm})$} & \multicolumn{2}{|c|}{ OD (mg/L) } \\
\hline & & & & & & & Inicial & Final & Inicial & Final & Inicial & Final \\
\hline Controle & & & & 100,0 & 0,0 & & 7,61 & 7,07 & 144,7 & 161,6 & 7,2 & 4,8 \\
\hline Efluente & & & & 116,1 & $-16,1$ & NT & 7,78 & 7,25 & 604,0 & 584,0 & 5,6 & 1,2 \\
\hline PAA & $5 \mathrm{mg} / \mathrm{L}, 20 \mathrm{~min}$. & & 0,82568 & 91,3 & 8,7 & NT & 7,65 & 7,00 & 601,0 & 606,0 & 9,4 & 1,0 \\
\hline UV & $78,96 \mathrm{mWs} / \mathrm{cm}^{2}$ & & & 113,9 & $-13,9$ & NT & 7,91 & 7,44 & 596,0 & 573,0 & 7,1 & 1,0 \\
\hline Ozônio & $29,9 \mathrm{mg} / / \mathrm{L}$ & & 1,44 & 133,0 & $-33,0$ & NT & 7,74 & 7,45 & 612,0 & 566,0 & 7,5 & 1,4 \\
\hline Ozônio & $45,15 \mathrm{mg} / / \mathrm{L}$ & & 1,56 & 100,0 & 0,0 & NT & 7,89 & 7,01 & 614,0 & 588,0 & 7,8 & 2,9 \\
\hline Cloro & $2,5 \mathrm{mg} / \mathrm{L}, 20 \mathrm{~min}$. & 0,03648 & 0,19188 & 132,6 & $-32,6$ & NT & 7,65 & 7,19 & 617,0 & 610,0 & 7,4 & 2,8 \\
\hline Cloro & $2,5 \mathrm{mg} / \mathrm{L}, 40 \mathrm{~min}$. & $<0,026$ & $<0,026$ & 130,9 & $-30,9$ & NT & 7,61 & 7,38 & 617,0 & 613,0 & 7,4 & 2,5 \\
\hline Cloro & 7,0 mg/L, $20 \mathrm{~min}$. & 0,48714 & 2,92692 & 54,3 & 45,7 & $\mathbf{T}$ & 7,73 & 7,06 & 631,0 & 650,0 & 7,3 & 3,9 \\
\hline Cloro & $7,0 \mathrm{mg} / \mathrm{L}, 40 \mathrm{~min}$. & 0,17634 & 2,41928 & 75,2 & 24,8 & NT & 7,66 & 7,09 & 629,0 & 605,0 & 7,6 & 0,7 \\
\hline
\end{tabular}

* Crescimento relativo (em relação ao controle). ** Inibição do crescimento em relação ao controle.

Tabela A-I.22. Toxicidade do efluente da ETE-Araraquara coletado em 17/11/04 antes e após a desinfecção com PAA, UV, Ozônio e Cloro e eficiência de remoção de Escherichia coli.

\begin{tabular}{|c|c|c|c|c|c|c|c|c|c|}
\hline \multirow{2}{*}{ Amostras } & \multirow{2}{*}{ [ ] ou De ou Dr } & \multirow{2}{*}{$\begin{array}{l}\text { Residual } \\
\text { Livre } \\
\text { (mg/L) }\end{array}$} & \multirow{2}{*}{$\begin{array}{l}\text { Residual } \\
\text { Total } \\
\text { (mg/L) }\end{array}$} & \multirow{2}{*}{$\begin{array}{c}\text { Eficiência } \\
\text { E. coli } \\
(\%)\end{array}$} & \multicolumn{4}{|c|}{ Mortalidade / Imobilidade (\%) } & \multirow{2}{*}{$\begin{array}{c}\text { Inibição de } \\
\text { Crescimento } \\
\text { A. Cepa }\end{array}$} \\
\hline & & & & & D. similis & D. rerio & C. xanthus & C. silvestrii & \\
\hline Efluente & & & & & NT & IT & NT & $T$ & NT \\
\hline PAA & $5 \mathrm{mg} / \mathrm{L}, 20 \mathrm{~min}$ & & 0,82568 & 99,992 & NT & $T$ & NT & $\mathbf{T}$ & NT \\
\hline UV & $78,96 \mathrm{mWs} / \mathrm{cm}^{2}$ & & & 99,282 & NT & $T$ & NT & $T$ & NT \\
\hline Ozônio & $29,9 \mathrm{mg} / / \mathrm{L}$ & & 1,44 & 99,144 & $\mathbf{T}$ & $\mathbf{T}$ & NT & $\mathbf{T}$ & NT \\
\hline Ozônio & $45,15 \mathrm{mg} / / \mathrm{L}$ & & 1,56 & 99,972 & $\mathbf{T}$ & $\mathbf{T}$ & NT & $\mathbf{T}$ & NT \\
\hline Cloro & $1,5 \mathrm{mg} / \mathrm{L}, 20 \mathrm{~min}$. & 0,03648 & 0,19188 & 99,994 & $\mathbf{T}$ & $\mathbf{T}$ & NT & $\mathbf{T}$ & NT \\
\hline Cloro & $1,5 \mathrm{mg} / \mathrm{L}, 40 \mathrm{~min}$. & $<0,026$ & $<0,026$ & 99,997 & $\mathbf{T}$ & $\mathbf{T}$ & NT & T & NT \\
\hline Cloro & $5 \mathrm{mg} / \mathrm{L}, 20 \mathrm{~min}$. & 0,48714 & 2,92692 & 100,000 & $\mathbf{T}$ & $\mathbf{T}$ & $\mathbf{T}$ & $\mathbf{T}$ & $\mathbf{T}$ \\
\hline Cloro & $5 \mathrm{mg} / \mathrm{L}, 40 \mathrm{~min}$ & 0,17634 & 2,41928 & 100,000 & $\mathbf{T}$ & $\mathbf{T}$ & $\mathbf{T}$ & $\mathbf{T}$ & IT \\
\hline
\end{tabular}



ANEXO II - FIGURAS 

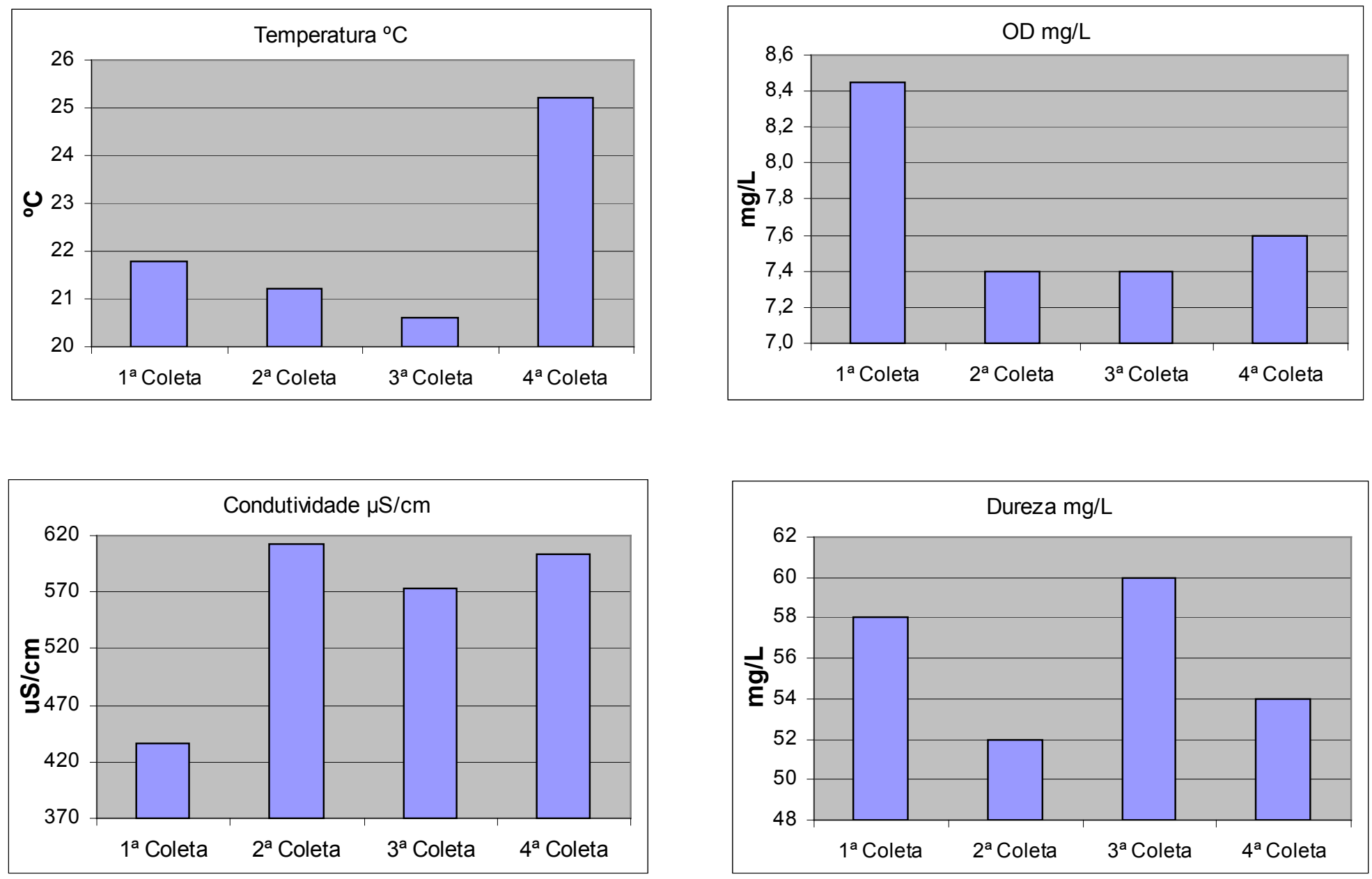

Figura A-II.1. Variação das medidas de temperatura, oxigênio dissolvido, condutividade e dureza em amostras de esgoto tratado da ETE-Araraquara coletadas em 15/09/03 ( $1^{\text {a }}$ coleta); 26/04/2004 ( $2^{\text {a }}$ coleta); 05/07/2004 ( $3^{\text {a }}$ coleta $)$ e 17/11/2004 (4a coleta). 

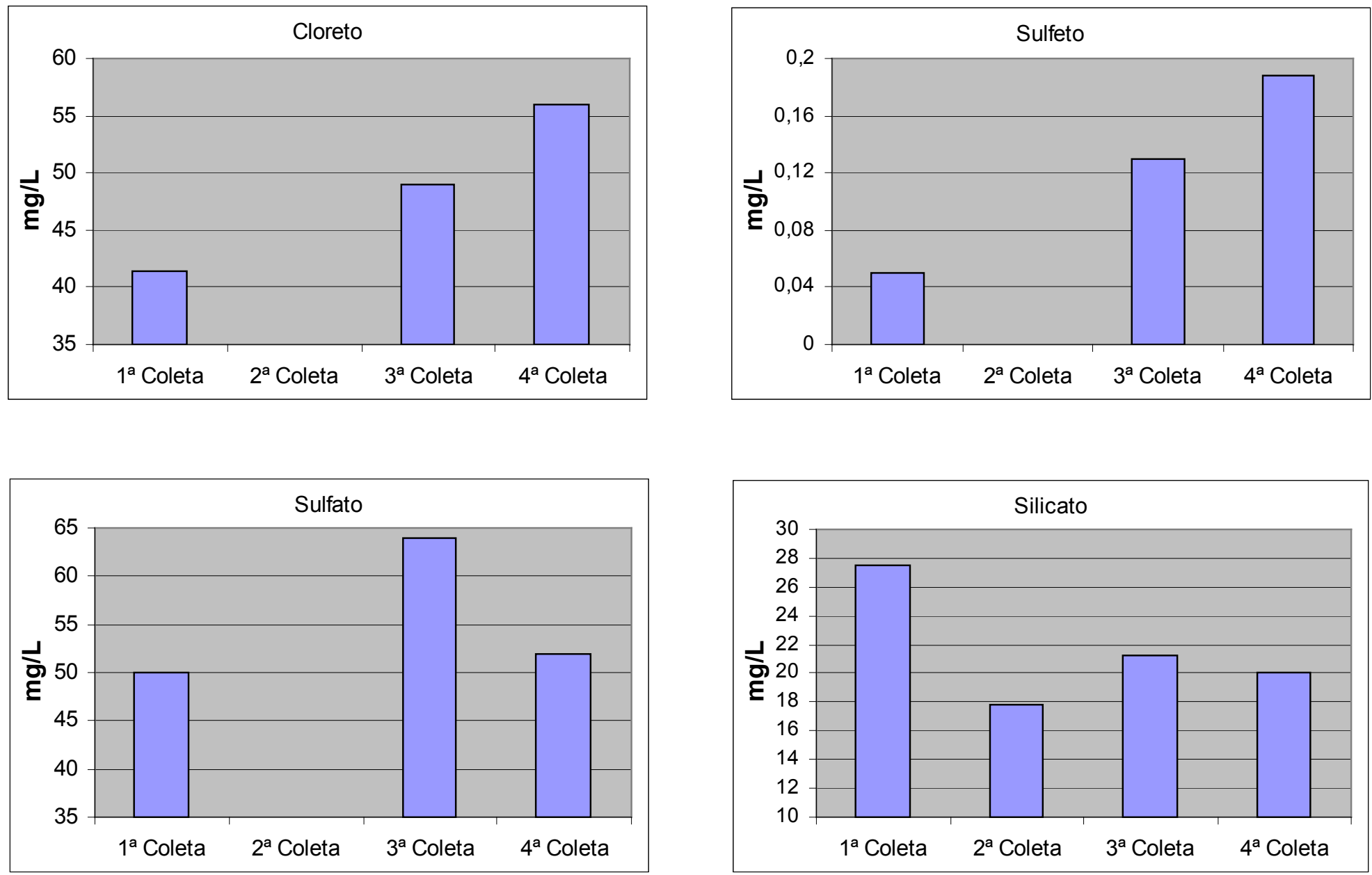

Figura A-II.2. Variação das medidas de cloreto, sulfeto, sulfato e silicato em amostras de esgoto tratado da ETE-Araraquara coletadas em 15/09/03 (1 ${ }^{\mathrm{a}}$ coleta); 26/04/2004 ( $2^{\text {a }}$ coleta); 05/07/2004 ( $3^{\text {a }}$ coleta) e 17/11/2004 (4 coleta). 

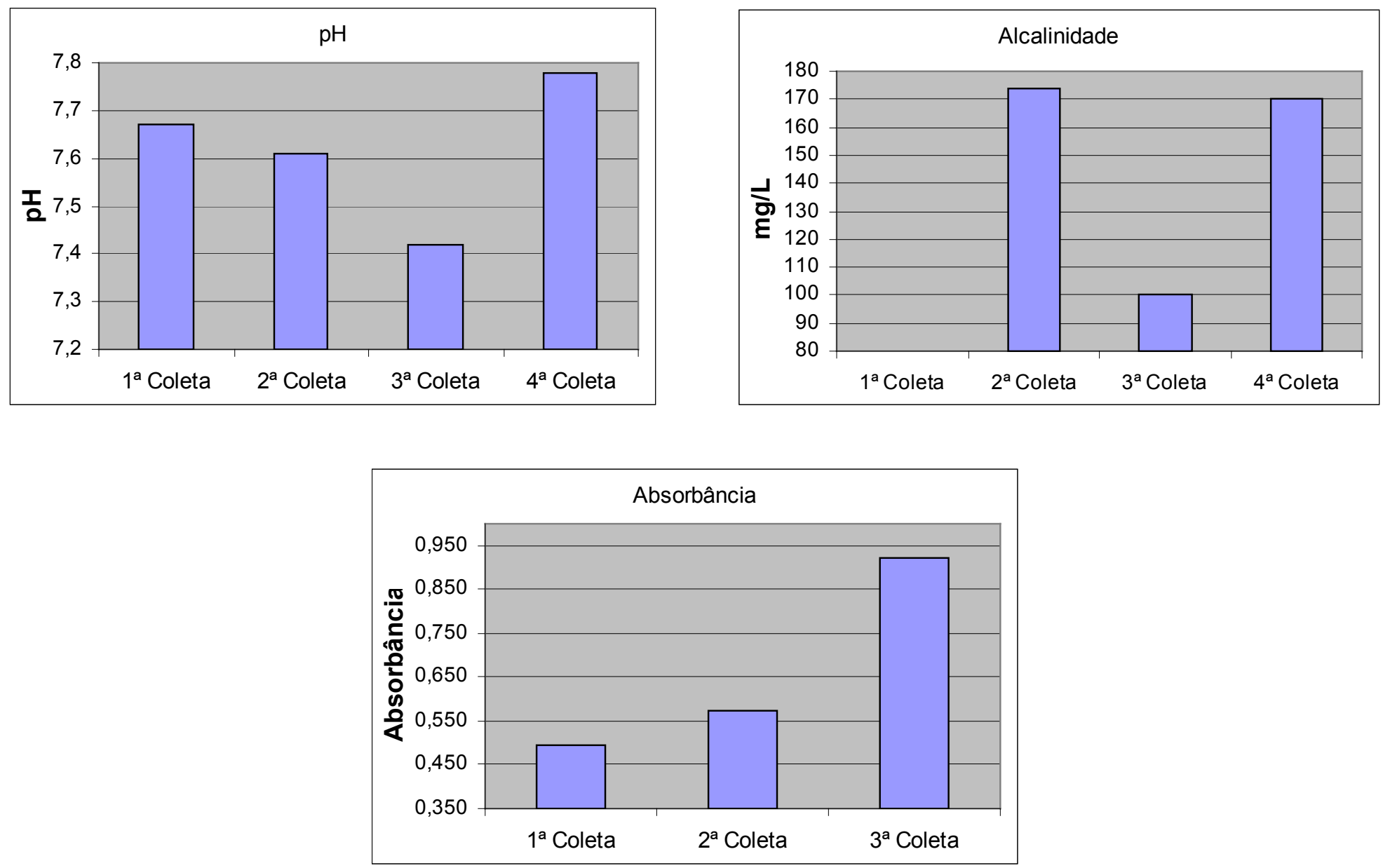

Figura A-II.3. Variação das medidas de pH, alcalinidade e absorbância em amostras de esgoto tratado da ETE-Araraquara coletadas em 15/09/03 (1 ${ }^{\mathrm{a}}$

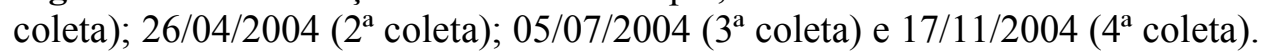



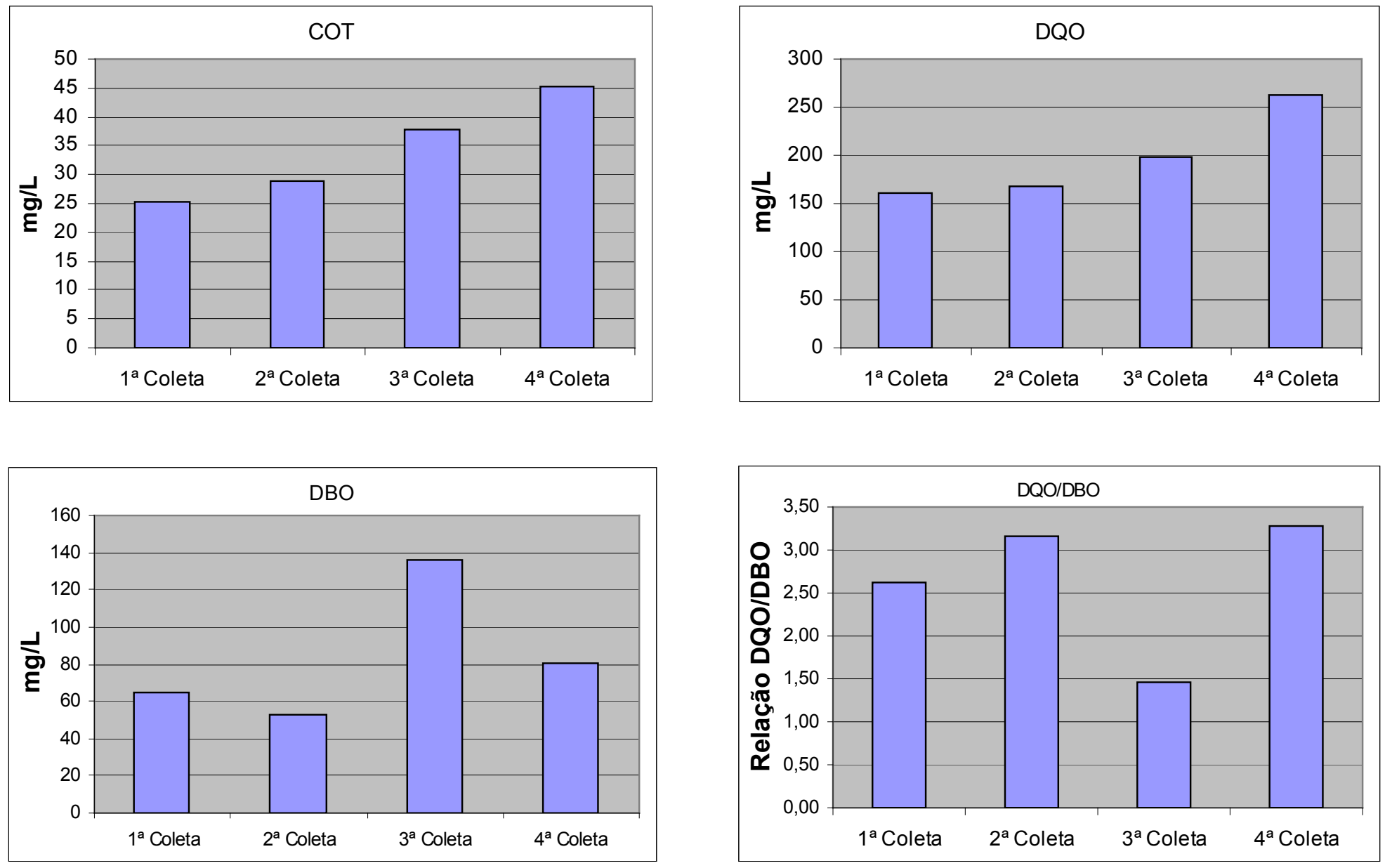

Figura A-II.4. Variação das medidas de COT, DQO e DBO em amostras de esgoto tratado da ETE-Araraquara coletadas em 15/09/03 (1ª coleta); 26/04/2004 ( $2^{\text {a }}$ coleta); 05/07/2004 ( $3^{\text {a }}$ coleta) e 17/11/2004 ( $4^{\text {a }}$ coleta). 

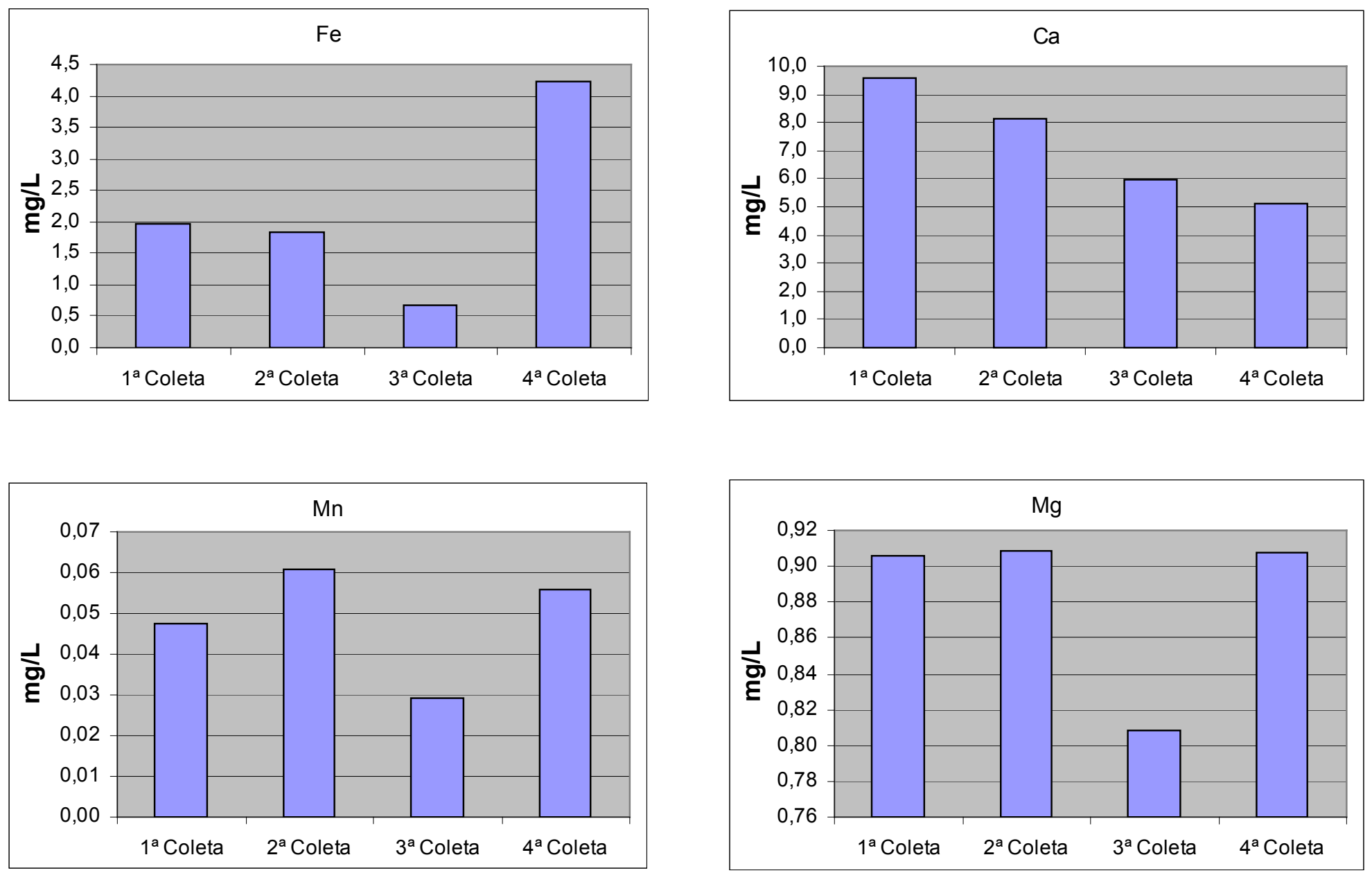

Figura A-II.5. Variação das medidas de metais (Ferro, Cálcio, Manganês e Magnésio) em amostras de esgoto tratado da ETE-Araraquara coletadas em 15/09/03 ( $1^{\text {a }}$ coleta); 26/04/2004 ( $2^{\text {a }}$ coleta $) ; 05 / 07 / 2004$ ( $3^{\text {a }}$ coleta $)$ e 17/11/2004 (4 ${ }^{\text {a }}$ coleta $)$. 

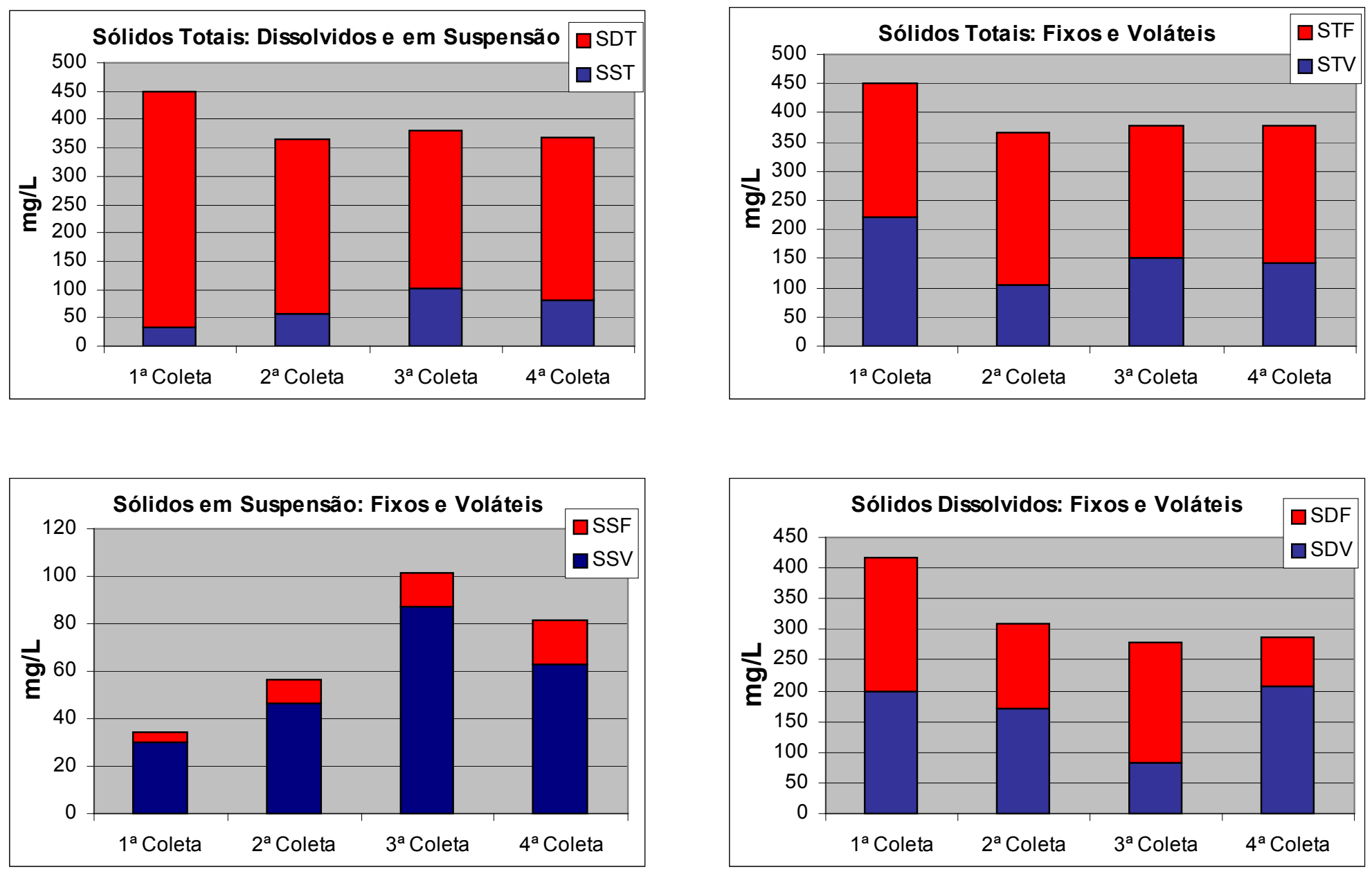

Figura A-II.6. Variação das medidas de sólidos totais, dissolvidos e em suspensão (fixos e voláteis) em amostras de esgoto tratado da ETE-Araraquara

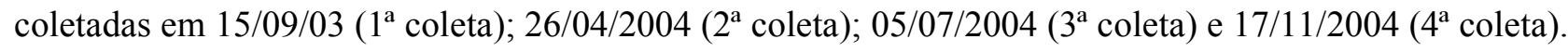



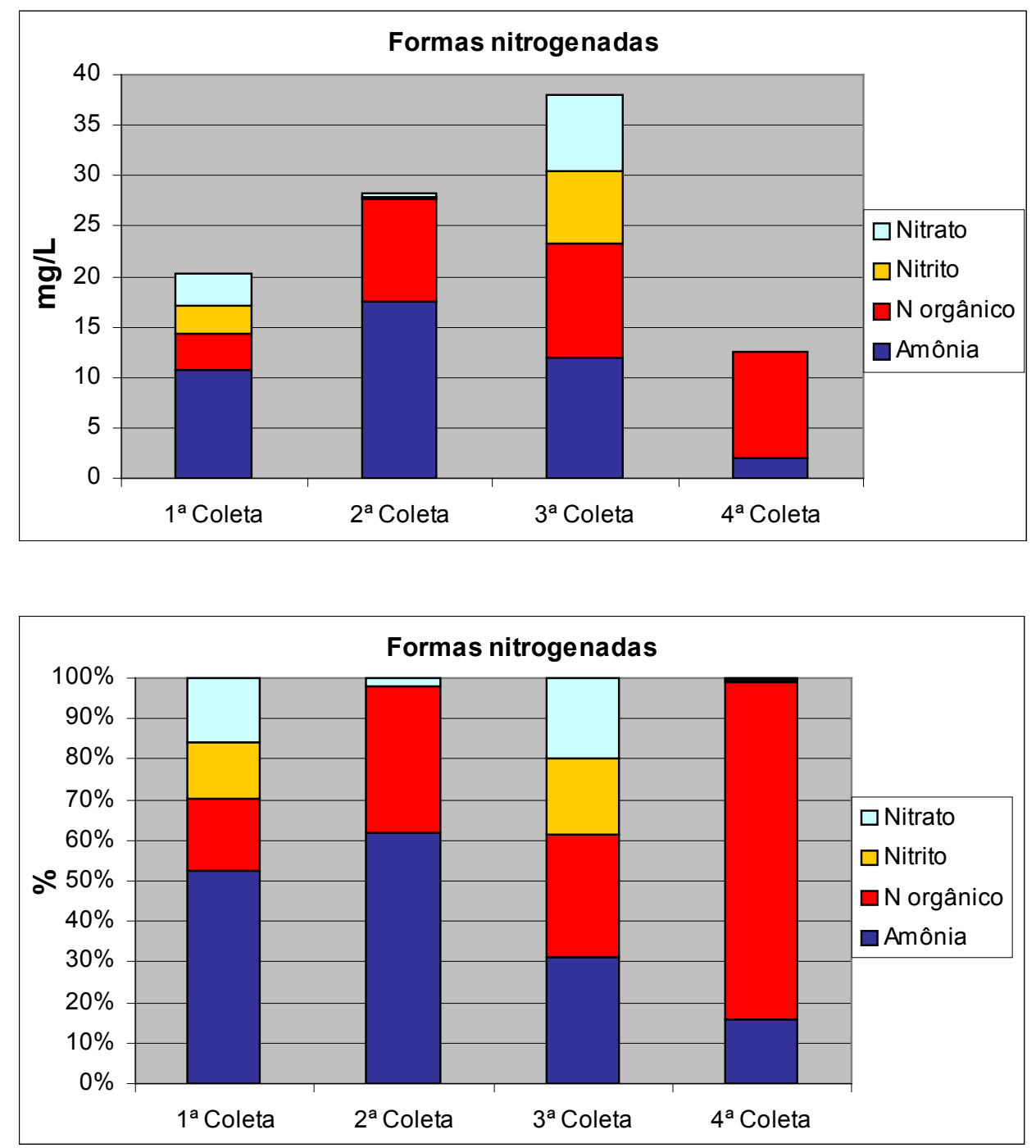

Figura A-II.7. Distribuição das formas de nitrogênio (mg/L e \%) encontradas no efluente tratado da ETE-Araraquara em diferentes amostragens. 

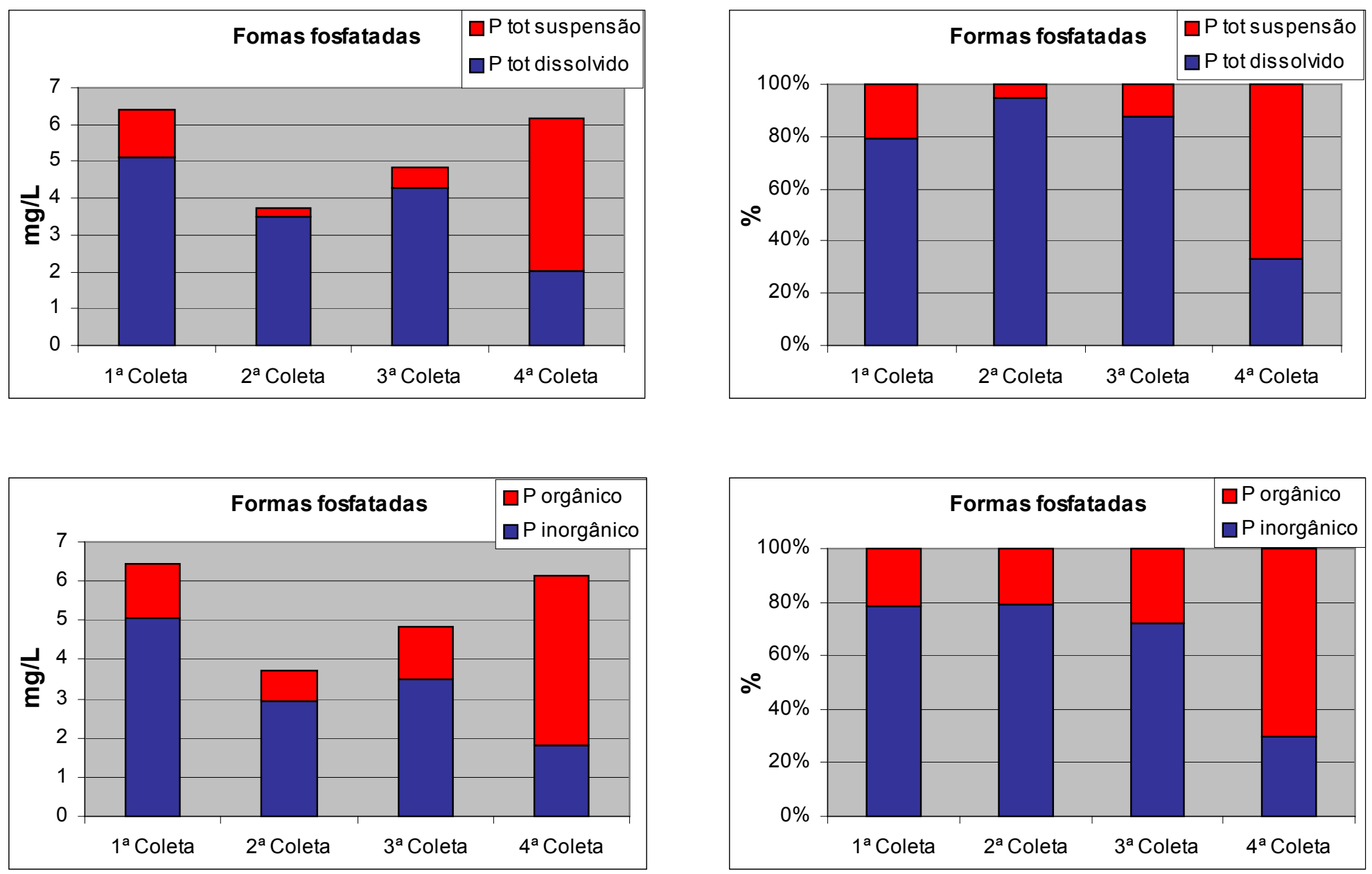

Figura A-II.8. Distribuição das formas de fósforo (mg/L e \%) encontradas em amostras do efluente tratado da ETE-Araraquara coletadas em 15/09/03

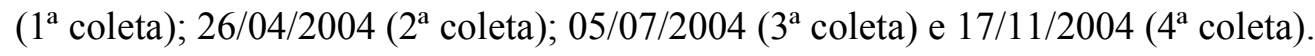



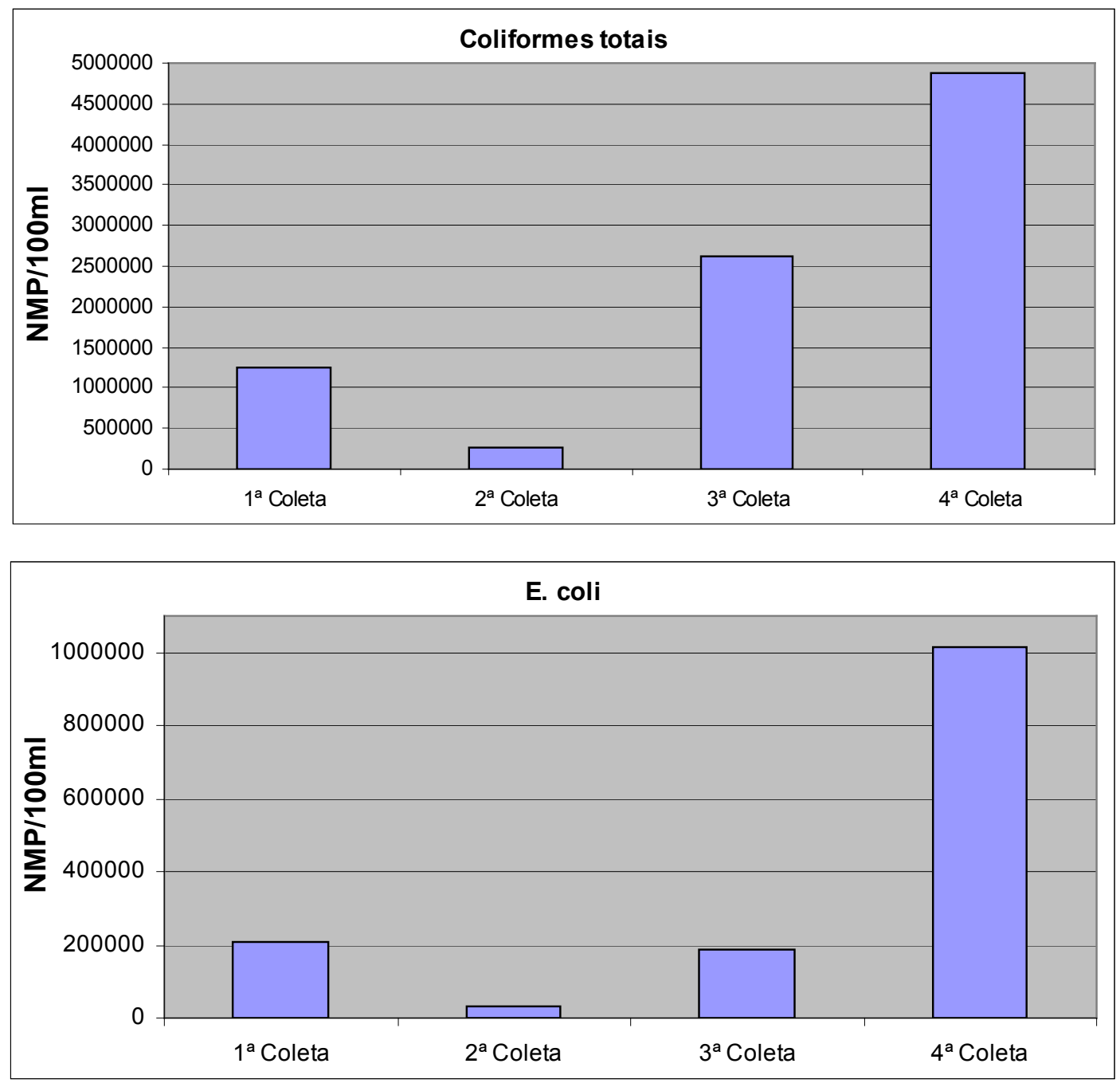

Figura A-II.9. Variação das concentrações de coliformes totais e E. coli no efluente tratado da ETE-Araraquara em diferentes amostragens. 